\section{Once-a-day Aricept}

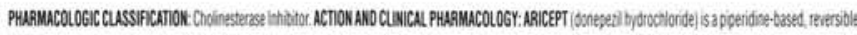

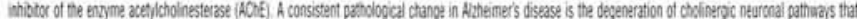

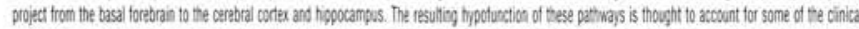

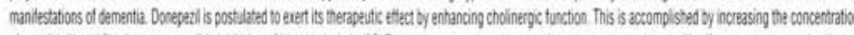

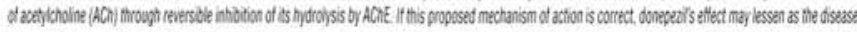

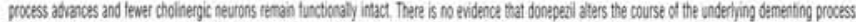

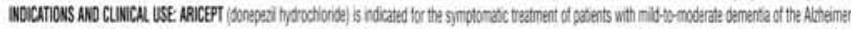

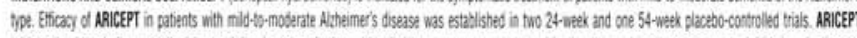

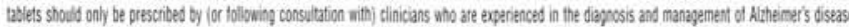

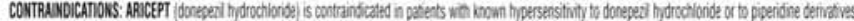

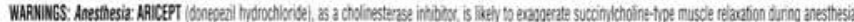

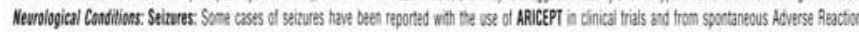

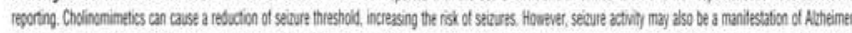

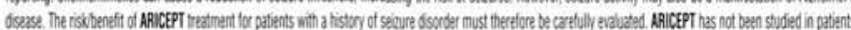

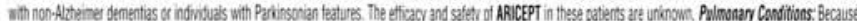

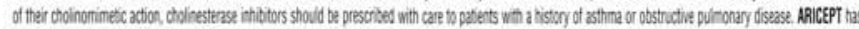

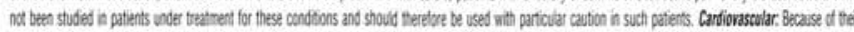

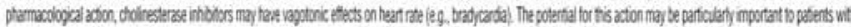

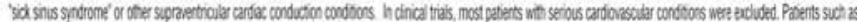

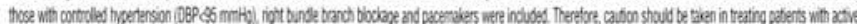

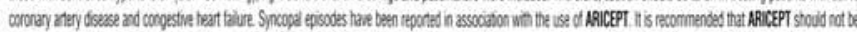

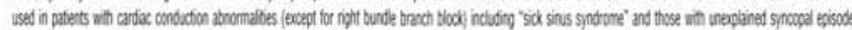

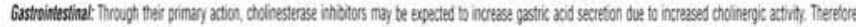

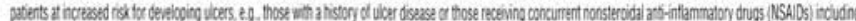

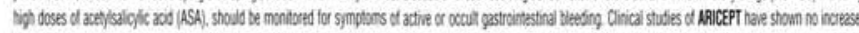

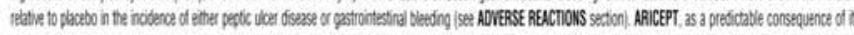

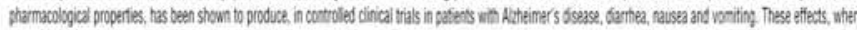

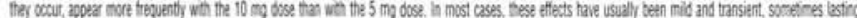

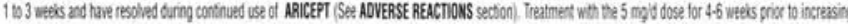

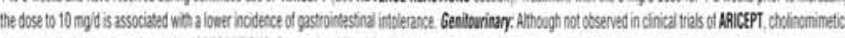

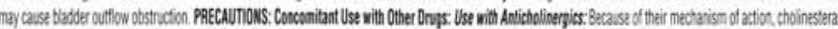

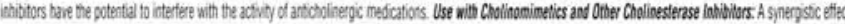

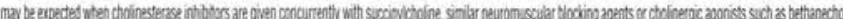

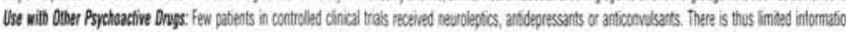

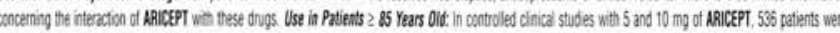

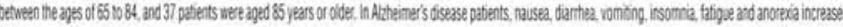

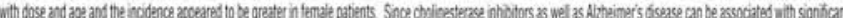

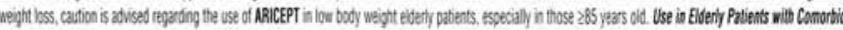

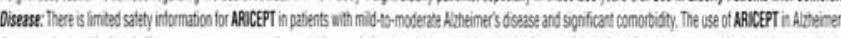

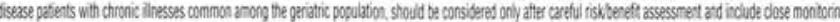

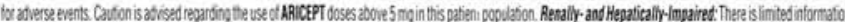

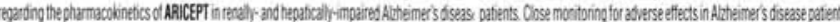

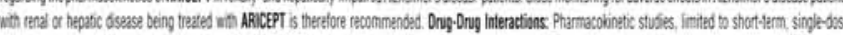

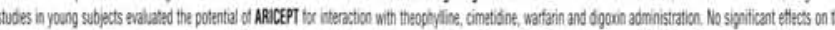

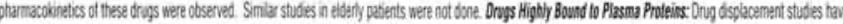

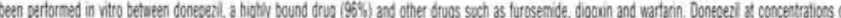

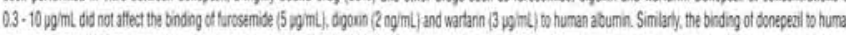

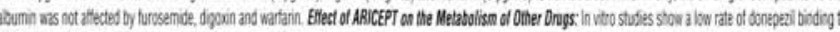

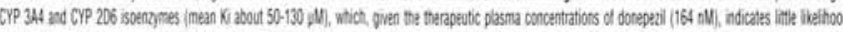

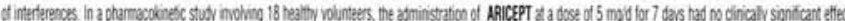

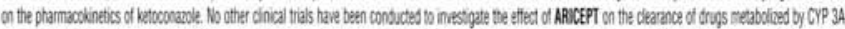

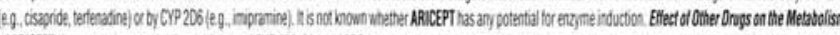

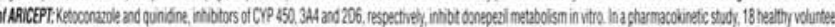

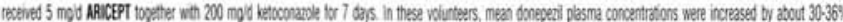

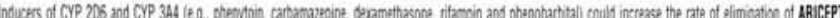

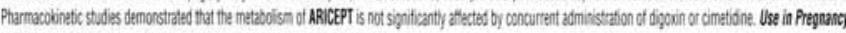

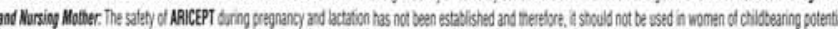

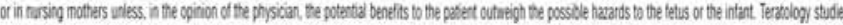

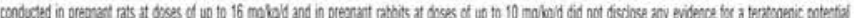

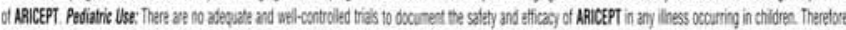

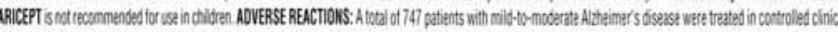

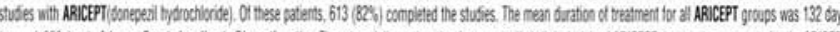

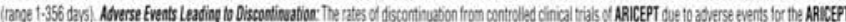

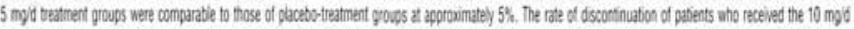

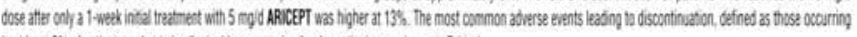

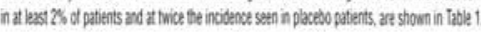

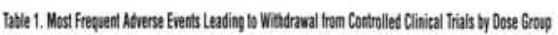

\begin{tabular}{|c|c|c|c|}
\hline Dose Groen & Placebo & $5 \mathrm{mg}$ A ARICEPT & $10 \mathrm{mg}$ d ARICEPT \\
\hline 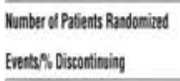 & 35 & 350 & 315 \\
\hline Nausea & 18 & is & $x$ \\
\hline Darrhes & $a s$ & 45 & $3 \%$ \\
\hline Wemiting & $d \%$ & $21 \%$ & $2 \%$ \\
\hline
\end{tabular}

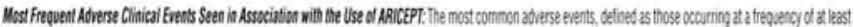

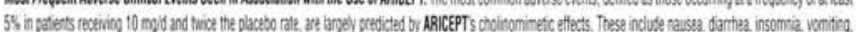

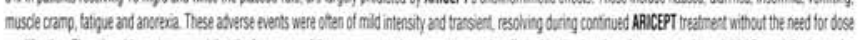

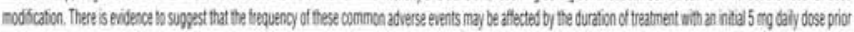

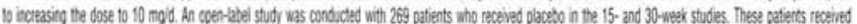

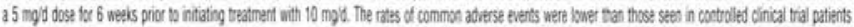

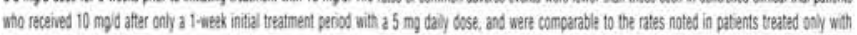
5 mgid. See table 2 tor a comparison of the most common adverse svents following 1 - and 6 -week initial treatimat periods with 5 mold AaICEPT.

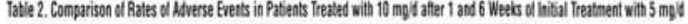

\begin{tabular}{|c|c|c|c|c|}
\hline \multirow[b]{2}{*}{ Atrerse Event } & \multicolumn{2}{|c|}{ No initial Ireaimeat } & \multirow{2}{*}{ 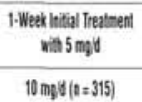 } & \multirow{2}{*}{ 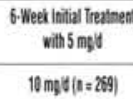 } \\
\hline & Piscedo $(n=315)$ & $5 \mathrm{mg} d(n=311)$ & & \\
\hline Nauses & $6 \%$ & $5 x$ & $19 \%$ & 68 \\
\hline Darthes & $5 \%$ & ss & $15 \%$ & 95 \\
\hline Insomnia & $6 \%$ & $6 \%$ & $14 \%$ & $6 \%$ \\
\hline Fabpue & $3 \%$ & th & $8 \pi$ & $3 h$ \\
\hline Voming & $3 \%$ & 3 & 8s: & 55 \\
\hline Musde Cramos & $2 \%$ & $6 \%$ & $8 \%$ & 35 \\
\hline Anorevis & $\gamma$ & $3 \%$ & 78 & 35: \\
\hline
\end{tabular}

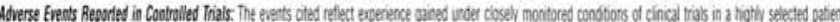

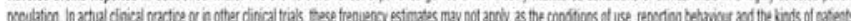

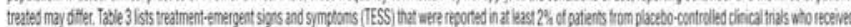

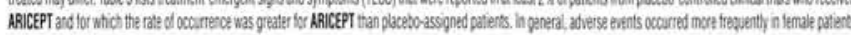
and with abancing age

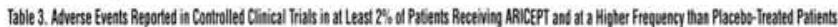

\begin{tabular}{|c|c|c|c|c|c|}
\hline $\begin{array}{l}\text { Body System/ } \\
\text { Adverse Erents }\end{array}$ & $\begin{array}{l}\text { Plasebo } \\
t=355\end{array}$ & $\begin{array}{l}\text { ARICEPT } \\
A=147\end{array}$ & $\begin{array}{l}\text { Boor System/ } \\
\text { Averse Erents }\end{array}$ & $\begin{array}{l}\text { Placebobo } \\
n=3655\end{array}$ & $\begin{array}{l}\text { ARICEPT } \\
1=747\end{array}$ \\
\hline Percent of Patients with any Adverse Event & 72 & 74 & Metabalic and Natritional & & \\
\hline Body as a Whale & & & Weipht Deccesse & 1 & 3 \\
\hline Heasache & 9 & 10 & Mastolossieletal System & & \\
\hline Pain, varous locations & 8 & 9 & Muscle Crangs & 2 & 6 \\
\hline Accodent & 6 & 7 & Antentis & 1 & 2 \\
\hline fabgue & 3 & 5 & Nervous System & & \\
\hline Cartiorascular SYstem & & & Insomia & 6 & 9 \\
\hline Synoopt & 1 & 2 & Duress & 6 & 8 \\
\hline Dinestive System & & & Depression & \& & 3 \\
\hline Nauses & 6 & 11 & Abnomal Dreans & 0 & 3 \\
\hline Darted & 5 & 10 & Somnolence: & a & 2 \\
\hline Voming & 3 & 5 & Urogenital & & \\
\hline Anorexis & 2 & 4 & Frequent Uinaten & 1 & 2 \\
\hline
\end{tabular}

Henic and Lymptatic Spstems

Ecothynosis

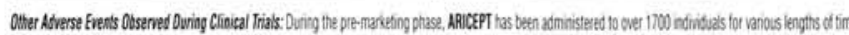

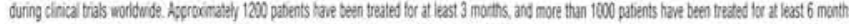

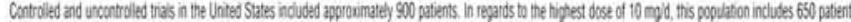

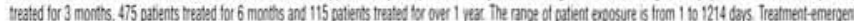

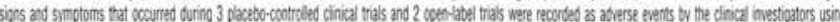

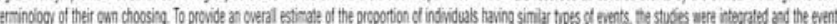

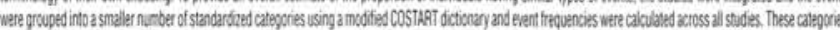

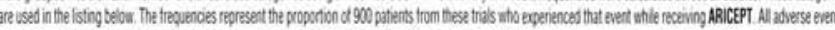

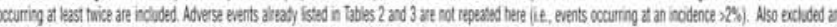

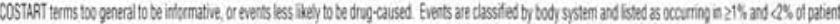

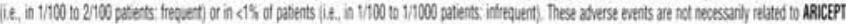

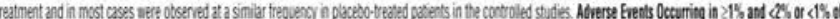

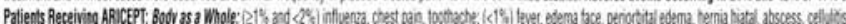

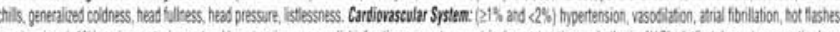

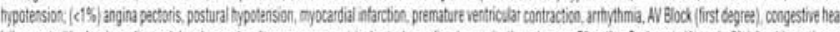

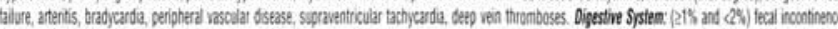

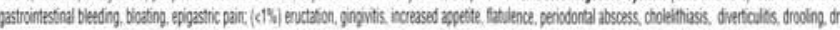

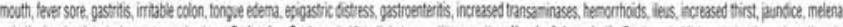

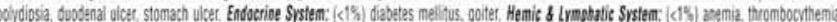

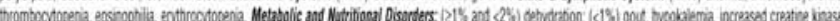

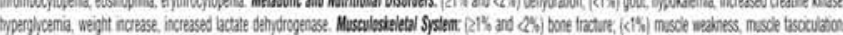

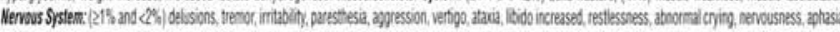

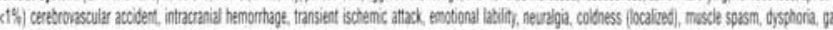

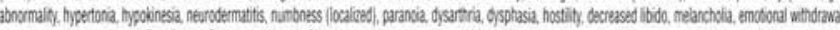

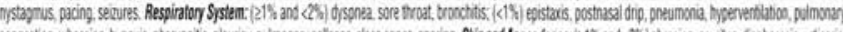

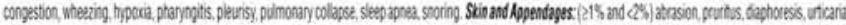

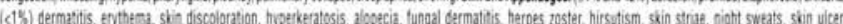

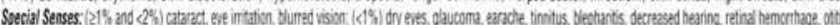

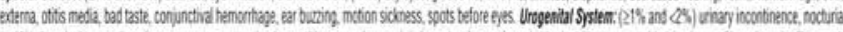

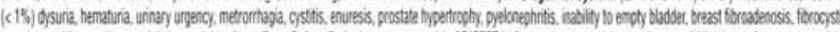

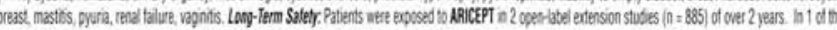

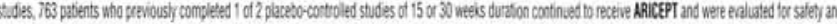

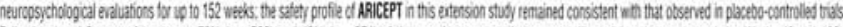

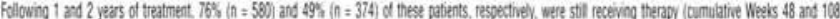

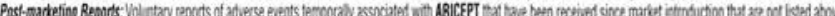

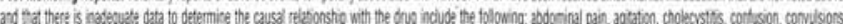

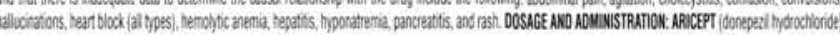

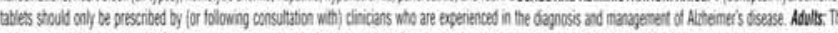

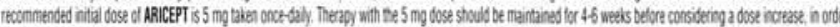

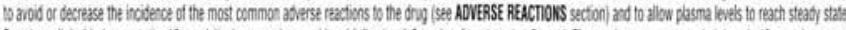

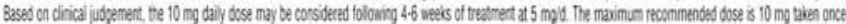

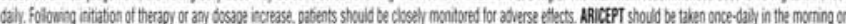

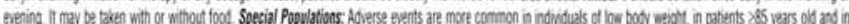

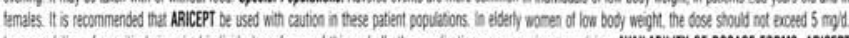

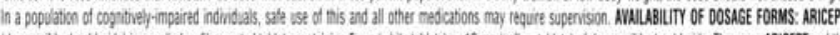

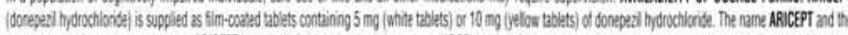

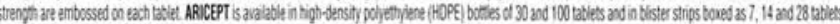
mentiestion of 2 stims of 14 tablets

References

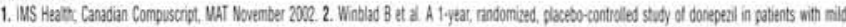

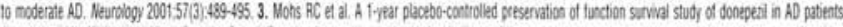

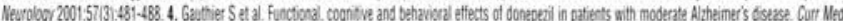

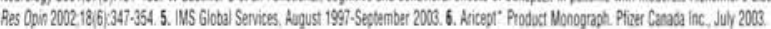

Product Mongraph anildete on reavest

Pfirer

NEUROSCIENCES
-TM Eisai Co. Ltd., Tokyo, Japan Pfizer Canada Inc., licensee Printed in Canada
(C) 2003 Pfizer Canada Inc. Kirkland,
H9J 2 M5 04AR23E $\overparen{P A B^{*}}$ 


\section{Interferon beta-1a \\ 'Rebif}

$11 \mathrm{mcg}$ (3MIU), 44 mcg (12MIU) lyophilized powder for injection

$22 \mathrm{mcg}$ (6MIU)). $5 \mathrm{~mL}, 44 \mathrm{mcg}$ (12MU)) $0.5 \mathrm{~mL}$ liquid formulation for injection

\section{THERAPEUTIC CLASSIFICATION}

\section{Immunomodulate}

\section{ACTIONS AND CUINIGAL PHARMACOLOGY}

Description: Rebif' (Interferon beta-1a) is a purified, sterile glycoprotein product produced by recombinant DNA techniques and formulated for use by injection. The active ingredient of Rebire is produced by genetically engineered Chinese Hamster Ovary (CHO) cells. Interferon beta-1a is a highly purified glycoprotein that has 166 amino acids and an approximate molecular weight of 22,500 daltons. It contains a single $\mathrm{N}$ linked carbohydrate moiety attached to Asn-80 similar to that of natural human Interteron beta The specific activity of Rebie is apcroximately 027 million internation al units (MIU)/mcg Interferon beta-1a. The unit measurement is derived by comparin the antiviral activity of the product to an in-house natural hiFN-beta NIH standard that is abtained trom human fibroblasts (BILS 11), which has been calibrated against the N natural hiFN-beta standard (GB 23-902-531). General; Interterons are a tamily of natirally occurring proteins, which have molecular weights ranging from 15,000 to 21,000 daltons. Three major classes of interferons have been identified alpha, beta, gamma Interteron beta, Interteron alpha and Interferon gamma have overlapping yet distinct biologic activities.

Interferon beta-1a acts through various mechanisms.

- Immunomodulation throunh the induction of cell membrane components of the major histocompatibility complex i.e. MHC Class I antigens, an increase in natural killer (NK) cell activity, and an inhibition of IFN-K induced MHC Class II antigen expression, as well as a sustained reduction in TNF level.

- Antiviral effect through the induction of proteins like $2^{\prime} \cdot 5^{\circ}$ oligoadenylate synthetase and $p 78$

- Antiproliferative effect through direct cytostatic activity and indirect through antitumoral immune response enhancerment.

The mechanism of action of Rebie" in relapsing-remitting multiple sclerosis is still under investigation.

\section{Relapsing-Remitting Multiple Sclerosis}

Two pivotal studies, including a total of 628 patients, evaluated the long-term satety and etficacy of Rebil" when administered subculaneously three times weekly to relapsing-remitting multiple sclerosis patients. The results indicate that Rebil" alters the natural course of relapsing-femitting multiple sclerosis. Etlicacy was demonstrated with respect to the 3 major aspects of this disease: disability (patients EDSS 0-5), exacerbations, and burden of disease and activity as measured by MRI scans.

\section{PRISMS STUDY}

In the larger trial, a total of 560 patients diagnosed with clinically definite or laboratorysupported relapsing-remitting multiple scierosis EDSS 0-5 with at least a 1-yer history before study entry, were enrolled and randomized to the 3 treatments (placebo, $22 \mathrm{mcg}$ (6MU) Rebif", or $44 \mathrm{mcg}$ (12MiU) Rebir") in a ratio of 1:11. About $90 \%$ od patients completed the 2 years of treatment, and very few patients withdrew from the study due to adverse events.

The main criteria for inclusion were

- history of 2 or more acute exacerbations in the 2 years prior to study entry

- no previous systemic treatment with inferferons

- no treatment with corticosteroids or ACTH in the 2 months preceding study entr

- no exacerbation in the 8 weeks prior to study entry.

Patients were evaluated at 3-month periods, during exacertations and coinciding with MRI scanning. Each patient underwent cranial proton density/T,-weighted (PD/T2) MRI scans at baseline and every 6 months during the study. A subset of patients underwent PD/T2 and $\mathrm{T}_{1}$-weighted (T1) Gd-MAI scans one month before the start of treatment, at baseline and then monthly until the end of the first 9 months of treatment. Of those, another subset of 39 continued with the monthly scans throughout the 24 month trealment period.

This study demonstrated that Rebit" at a total dose of 66 or $132 \mathrm{mcg}$ weekly. significantly improved all 3 major cutcomes, including exacertation rate, disease activity and burden of disease as measuted by MRI scanning and progression of disability. In addition, the study showed that Rebif is effective in delaying the progression in disability in patients with an EDSS of 4.0 or higher who are known to progress more rapidly. Also, the drug reduced the requirements for steroids to treat multiple sclerosis and at 132 mcg weekly Rebif" reduced the number of hospitalizations for multiple sclerosis. Ettect on exacertation

\begin{tabular}{|c|c|c|c|c|c|}
\hline \multirow[t]{2}{*}{ Etlicacy parameters } & \multicolumn{3}{|c|}{ Tiesthent Groups } & \multicolumn{2}{|c|}{ Devalue } \\
\hline & Nucato & 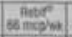 & 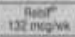 & 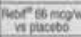 & 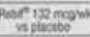 \\
\hline 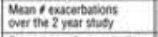 & 2.56 & 1,82 & 1.73 & 0.0002 & 000001 \\
\hline 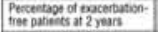 & 1465 & 25.65 & 32.05 & 0.0140 & $\$ .0001$ \\
\hline 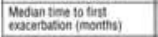 & 45 & 76 & 9.6 & 0.0008 & 0.0001 \\
\hline 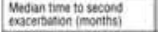 & 150 & 23.4 & $324^{\circ}$ & 0.0020 & $\$ .0001$ \\
\hline 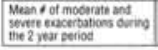 & 099 & 0.71 & 0.62 & 0.0025 & 0.0003 \\
\hline
\end{tabular}

The results after one year of treatment were also significant.

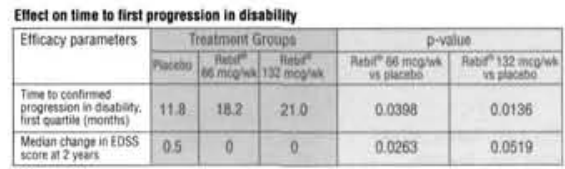

\begin{tabular}{|c|c|c|c|c|c|}
\hline \multirow[t]{2}{*}{ Eflicacy parameters } & \multicolumn{3}{|c|}{ Iresatineat Groups } & \multicolumn{2}{|c|}{ D-value } \\
\hline & Poncesos & 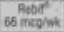 & $\begin{array}{l}\text { peor } \\
132 \text { incown }\end{array}$ & Peer of mover & 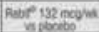 \\
\hline $\begin{array}{l}\text { Burdee of disease (B00) } \\
\text { Wedan } \$ \text { crasco }\end{array}$ & 10.9 & .12 & -3.8 & 80.0001 & $<0.0001$ \\
\hline \multirow{2}{*}{\multicolumn{6}{|c|}{ MAI active }} \\
\hline & & & & & \\
\hline 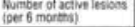 & 225 & 0.75 & 95 & 0.0001 & $\$ .0001$ \\
\hline S xtries scams & $75 \mathrm{~s}$ & $50 \%$ & $25 \%$ & 8.0001 & 0.0001 \\
\hline \multicolumn{6}{|c|}{ Palients with manthily MRlis (9 months) } \\
\hline 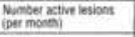 & 0.88 & 0.17 & 0.11 & 0.0001 & 0.0001 \\
\hline S acove scass & $4 \%$ & $125 \%$ & $11 \%$ & 50.0001 & $\$ 0001$ \\
\hline \multicolumn{6}{|c|}{ 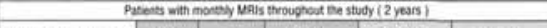 } \\
\hline Wumbet active lesions & 0.9 & 0.1 & 0.02 & 0.0905 & 0.0105 \\
\hline S sative sans & $52 \%$ & $10 \%$ & 25 & 0.0920 & 00117 \\
\hline
\end{tabular}

Requirement for steroids: The proportion of patients requiring steroids for MS lexcluding non-MS indications) was higher in the placebo group (more than 50\%) than either of the 2 Rebif" groups (around $40 \%$ in each group).

Hospitalization for multiple sclerosis: The observed mean numbers of hospitalization for MS in the Rebif" 66 and $132 \mathrm{mcg}$ weekly groups represented reductions of $21 \%$ and $48 \%$, respectively, from that in the placebo group.

\section{Cohort of patients with high baseline EDSS (baseline EDSS $>3.5$ ):}

Additional analyses were conducted in order to study the efficacy of Rebie in popul tions of patients with adverse predictive outcome factors, who were likely to be at highe risk for progression in disability. The primary predictive factor examined was baselin EDSS $\times 3.5$. Patients in this cohort have a more severe degree of disability and are a higher risk for progression than those with lower EDSS: natural history studies have shown that patients at EDSS leveis of 4.0 to 5.0 spend less time at these EDSS levels than at lower levels of disability. Treatment with Rebite at both doses significantly reduced the mean exacerbation count per patient compared to placebo treatment. Progression in this group of patients is of particular concern, as it involves development of difticulty in ambulation. The $132 \mathrm{mcg}$ weekly dose significantly prolonged time confirmed progression whereas the $66 \mathrm{mcg}$ weekly dose did not. Both doses of Rebif significantly aftected percent change from baseline in MRI burden of disease in the high-EDSS cohort, and the $132 \mathrm{mcg}$ weekly dose significantly reduced the number of $\mathrm{T}$ active lesions in this population. The efficacy results in this cohort of patients with established disability confirms that the $132 \mathrm{mcg}$ weekly dose has a marked effect on progression in disability and the underlying pathology of the disease.

\section{EHect on exacerbation (High-EDSS cohorr)}

\begin{tabular}{|c|c|c|c|}
\hline Eflicacy parameters & Plactio & $\begin{array}{c}\text { Pasbifs } \\
66 \text { mcgiweek }\end{array}$ & $\begin{array}{c}\text { Aebit: } \\
132 \text { mog/week }\end{array}$ \\
\hline Mean $f$ exacerbations & 307 & 1.83 & 1.22 \\
\hline t and 5 of exacerbation-tree patients & 200 & $\tan x$ & $10(25)$ \\
\hline p-value "(Rebir" vs placebo) & & pe-00121 & $0,0.0002$ \\
\hline
\end{tabular}

\section{Progression in disability by one point on the EOSS (Migh-EDSS cohort)}

\begin{tabular}{|c|c|c|c|c|}
\hline \multirow[t]{2}{*}{ Treatment Group } & \multirow{2}{*}{$\begin{array}{c}\text { \%ol } \\
\text { propressors. }\end{array}$} & \multicolumn{3}{|c|}{ Time to Progression } \\
\hline & & I patients & Median (days) & Q1 (days) \\
\hline Placobo & $50 x$ & $a$ & 638 & 219 \\
\hline Rebil' 66 meg weekly & 415 & 35 & notrached & $2 \mathrm{a}$ \\
\hline Rebir 132 meg weeby & $2 n$ & 31 & ner ravered & 60 \\
\hline
\end{tabular}

"Excludes patients lost to tollow-up without progreassion

\begin{tabular}{|c|c|c|}
\hline \multirow{3}{*}{\begin{tabular}{|l|} 
Test \\
Log-rank test
\end{tabular}} & Grovip Compuritean & p-value \\
\hline & 66 incg woekly va placebo & $p=0.4465$ \\
\hline & 132 mco weedsy vs placobo & $D=0.0481$ \\
\hline
\end{tabular}

\begin{tabular}{|c|c|c|c|}
\hline \multicolumn{4}{|l|}{ MAI Burden of Disease: \%o Change } \\
\hline & Procebo & $\begin{array}{l}\text { Rebir" } \\
66 \text { moginatex }\end{array}$ & $\begin{array}{c}\text { Rebil" } \\
132 \text { mogyweek }\end{array}$ \\
\hline Burden of disease - Median \% change & 53 & थ & 69 \\
\hline Burden of disease - Mean $\$$ change & 122 & 136 & a. \\
\hline D-value" (Rebir vs placebo) & & peovies & pe002067 \\
\hline
\end{tabular}

\section{-AVOVA on the ranks.}

Number of T2 Active Lesions (High-EDSS cohort)

\begin{tabular}{|c|c|c|c|}
\hline & Number & ve Lesions & \\
\hline Treatment Group & Median & Nean & p-value: \\
\hline Placebo & 19 & 28 & \\
\hline Rebir $66 \mathrm{mcg}$ weekly & 09 & 17 & 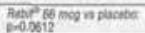 \\
\hline Rebif" $132 \mathrm{mog}$ weekly & QS & 09 & 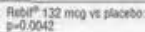 \\
\hline
\end{tabular}

\section{CROSS-OVER STUDY}

The other study was an open cross-over design, with MRI evaluations conducted in a blinded fashion. Enrolled in this study were 68 patients between the ages of 15 and 45 years, with clinically definite and/or laboratory supported relapsing-remilting MS for up to 10 years in duration. The main inclusion criteria included.

- at leasi 2 relapses in the previous 2 years

- EDSS score between 1-5

- no corticosteroid or plasmapheresis treatments or administration of gamma globulin within the 3 months prior to study

- no immunomodulating or immunosuppressive therapy for the 6 months prior to the study

- absence of HBSAg and HIV antibodies

Once enrolled, patients remained under clinical observation for 6 months with assessments of their neurological status and other parameters, and extensive monitoring of exacerbations. Patients were then randomized to treatment with either 11 mog (3MMU) $(n=35)$ or $33 \mathrm{mcg}(9 \mathrm{MIU})(\mathrm{n}=33)$ of Rebif", sell-administered subculaneously three times per week. The total dose was theretore 33 or $99 \mathrm{mcg}$ weekly.

\section{Six-months observation vs six-months treatment}

Treatment with Rebif at both doses used in this study, achieved a statistically significant reduction in both the MRI evidence of MS activity in the brain and the clinical relapse rate versus the corresponding observation periods. This pattern of improvernent was also reflected in additional MRI measures. In the biannual $T_{2}$-weighted scans, a reduction in the mean number of new lesions and in the mean number of enlarging lesions was demonstrated.

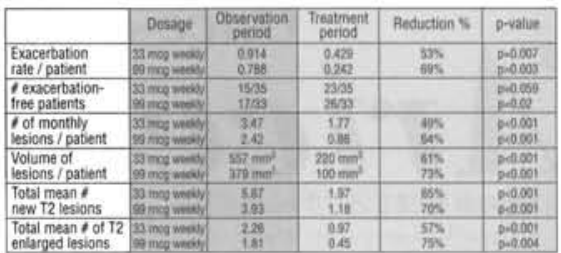

Two-year results: At the end of this study, 62 patients continued treatinent for a further 18 months. Each of these patients continued to receive the dose to which they wer randomized. Validation of the results of the 2 year treatment period is ongoing, however the results from the continuation of treatment at both doses demonstrate that Rebif maintained its dose-dependent effect in reducing the relapse rate and the brain lesion volume detected by $T_{2}$ weight MRI scans compared to the observation period, which corroborates the findings of the longer, placebo-controlled study.

Condyloma acuminatum: The results from four double-blind, placebo-controlled studies, including 349 patients (aged 17-62), each reveal that Rebif", when injected intralesionally at a dose of $3.67 \mathrm{mcg}$ (1MiU)/lesion 3 times per week for 3 weeks, is etficacious in the treatment of condyloma acuminatum in men and women. This efficacy is evidenced by both the induction of complete disappearance of lesions as well as the reduction in the area of lesions. The majority of treated patients in these studies had recurrent warts that had tailed previous treatments. The number of lesions treated per patient was between 3 and 8 , as stated in the summary table below.

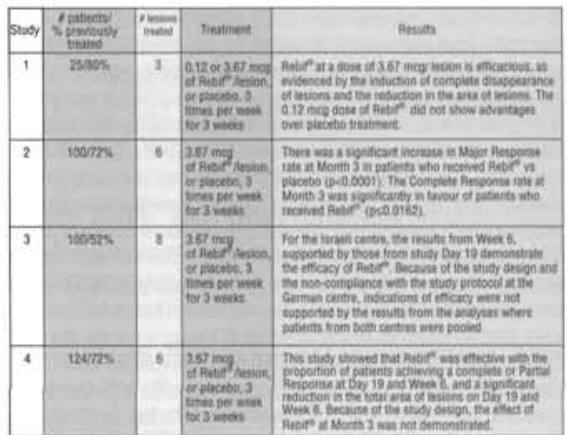

\section{INDICATIONS AND CLINICAL USE}

Multiple Sclerosis: Rebif" (Interteron beta-1a) is indicated tor the treatment of relapsing-remitting multiple sclerosis in patients with an EDSS between 0 and 5.0 to reduce the number and severity of clinical exacerbations, slow the progression of physical disability, reduce the requirement for steroids, and reduce the number of hospializations for treatment of multiple sclerosis. The efficacy has been confirmed by $T_{1}-G d$ enhanced and $\mathrm{T}_{2}$ (burden of disease) MRI evaluations. Evidence of efficacy beyond 2 years is not known since the primary evidence of efficacy derives from 2-year trials. Condyloma acuminatum: Rebif" is best sulted for the patient who has less than nine lesions, and who has tailed several prior treatments. In the case of patients with nine or more lesions, if the first Rebil" treatment is successtul, the remaining lesions could be treated with a second course of Rebif" therapy. Rebif" should also be considered for the treatment of condyloma acuminatum in patients for whom the side-effects from other treatments. en scarting are of concern While not all patients who were treated with Rebit" attained a complete response, patients whose lesions decreased in size and had at least a partial response may have also benefitted from treatment because lesion shrinkage may facilitate subsequent management with other therapies, as has been reported with IFN-alpha.

CONTRAINDICATIONS: Rebif" (Interferon beta-1a) is contraindicated in patients with anown hypersensitivity to natural or recombinant interferon beta, albumin (human), of any other component of the formulation.

WARNINGS: Rebil" (Interteron beta-1a) should be used under the supervision of a physician

Relapsing-Remitting Multiple Sclerosis: Depression and suicidal ideation are known to occur at an increased frequency in the mulliple sclerosis population. The use of Rebif" has not been associated with an increase in the incidenoe and/or severity ol depression, of with an increased incidence of suicide attempts or suicide. In the relans. ing-remitting multiple sclerosis study, a similar incidence of depression was seen in the placebo-treated group and in the two Rebif" patient groups. Nevertheless, patients with depression should be closely monitored tor signs of significant worsening of depression or suicidal ideation. The first injection should be pertormed under the supervision of an appropriately qualified health care professional.

Condyloma: All injections should be administered by a qualified health care protes-

\section{PRECAUTIONS}

General: Patients should be intormed of the most common adverse events associated with interferon beta administration, including symptoms of the flu-like syndrome (see Adverse Reactions). These symptoms tend to be most prominent at the initiation of therap and decrease in frequency and severity with continued treatment:

Based on the results of clinical trials of Rebif" in MS, in which more than 500 patients were randomized to drug treatment. there is no indication of an increased risk of seizure disorder with Rebife therapy. However, since seizures have been reported with other interferon therapies, caution should be exercised when administering interferon-beta-1a lo patients with pre-existing seizures disorder. For patients without a pre-existing seizure disorder who develop seizures during therapy, an etiologic basis should be established and appropriate anti-convulsant therapy instituted prior to considering resuming treatment with Rebif?. The effect of Rebift administration on the medical management of patients with seizure disorder is unknown.

Serum neutralising antibodies against Rebif" (interferon beta-1a) may develop. The precise incidence and clinical significance of antitoodies is as yet uncertain (see ADVERSE REACTIONS).

typersensitivity reactions, both local and systemic, have developed during therapy with Rebif.

Intralesional injections can be painful to some patients treated for condyloma acuminats In such cases an anaesthetic cream such as lidocaine-prilocaine can be used Pregnancy and Lactation: Rebif" should not be administered in case of pregnancy and lactation. There are no studies of interteron beta-1a in pregnant women. At high 
doses in monkeys, atootifiacient effects were observed with other intertarons. Fertile women receiving Rehit should take appropriate contraceptive measures. Patients planning for pregnancy and those becoming pregnant should be intormed of the potentias hazards of interterons to the foetus and Rebit should be discontinued. It is not know whether Rebif is excreted in human milk. Because of the potential for serious adverse reactions in nursing intants, a decision should be made either to discontinue nursing on to ciscontinue Rebit therapy

Pediatric use: There is no experience with Rebif in childien under 16 years of age with multiple sclenosis of condyloma and thereflore Rebit should nor be used in this population

Patients with Special Diseases and Conditions: Caution should be used and close monitoring considered when administering Rebit to patients with severe renal and hepatic tailure, palients with severe tinyelosuppression, and degressive patients

Drug Interaction: No formal drug interaction studies have been conducted with Rebit in humans interterons trave been reported to reduce the activity of hepatic cylochrome 0450-dependent encymes in humans and animals Caution shyuld be exercised when administering Rebif in combination with medicinal products that have a nartow therapeutic index and are largely dependent on the hepatic cyochrome p450 system tor clearance, eg. antiepileptics and some classes of antidepressants. The interaction of Rebif with corticosteroids or ACTH has not been studied systematically Clinica studes indicate that multiple scletosis patients can receive Retit and corticosteroids of ACTH duting relanses. Rebit should not be mixed with other drugs in the same syringe

\section{Laboratory Tests}

Relapsing-Remitting Multiple Sclerosis: L aboratory abnormalities are associated with the use of interterons. Therefore, in addition to those laboratory tests normally required for monitoring patients with muliple sclerosis, complete and differential white blood cell counts, platelet counts and blood chemistries, including liver and thyroid function tests are recommended during Rebit therapy. These tests should be pertormed at months 1.3 and 6 , and every 6 months thereatter

Condyloma acuminata: Same as relapsing-remilting muliple sclerosis but tend not to be as severe because of dose and length of treatment

Information to be provided to the patient: Flu-like symotoms (lever, headache chills. muscle aches) are not uncommon following inifiation of therapy with Rebif Acelaminophen may be used tor reliet of flu-like symptoms. Patients should contac their physician or pharmacist if they experienos any undesirable effects. Depression may occur in patients with relapsing-remitting multiple sclerosis and may occur while patients are laking Rebit Patients should be asked to contact their physician should they feel depressed. Patients should be advised not to stop of modity their trealmert unless instructed by their physician. Instruction on selt-injection technique and procedures: patients treated tor relapsing-remitting muliple sclerosis should be instructed in the use of aseptic technique when administering Rebit' Appropriate instruction to reconstitution of Rebif and selt-injection stould be given including caretul review of the Rebit patient leatiet. The first injection should be perturned under the supervision of an appropriately qualified healthcare protessional. Injection sites should be rotated at each injection. lnjections may be given prior to bedtime as this may lessen the perception of side eflects. Pazients strould be caulioned against the re-use of needles or syringes an instructed in sate disposal procedures. A pundure tesistant container tor disposal of used needles and syringes should be sugplied to the patient along with instructions for sate disposal of full containers. In the controlled MS trial reparted injection site reaction were commonly teported ty patients al one or more fimes during therapy. In genera they did not require discontinuation of therapy, but the nature and severity of all reported reactions should be caretully assessed. Patient understanding and use of aseptic selt. injection technique and procedures should be periodically re-evaluated

\section{ADVERSE REACTIONS}

Multiple Sclerosis: As with other interferon preparations, llu-like symptoms are no uncommon. The use of interteron beta may cause flu-tike syndrome. asthenia. pyrexia chills, arthralgia myalgia headache, and iniection ste reactions

Less frequent adverse reactions include cold sores, stutty nose. light headedness, mucosal irritation, haematological disorders (leukopenia. Iymphopenia, granulocylopenia), and alterations in liver lunction tests such as elevated SGOT and SGPT. Thes effects are usually mild and reversible. Tachyphylaxis with respect to most side-effects is well recognized. Fever and flu-like symptoms can be treated with acelaminopher. Depending on the severity and persistance of the side-effects, the dose may be lowered ar tembocarily intertupled, at the discretion of the physician. Most iniection site reactions are mild to moderate. Rare cases of skin ulperationinnecrosis at the site of iniection have been reported with long term treatment. The most trequently reported adverse events and the most common laboratory abromalifies observed during the placebo-con trolled study in relapsing-remiting multiple sclerosis (560 patients, 2 years treatment) are presented in the lable below for patients on placebo and Rebif' (interleron beta-1a). The frequencies are patients who reported this event al least once during the study, as a percentage of the total number of patients. by study-am.

\begin{tabular}{|c|c|c|c|}
\hline & Placeto & $\begin{array}{l}\text { Aebif } \\
66 \text { mca wenty }\end{array}$ & 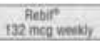 \\
\hline \multicolumn{4}{|c|}{ Adverse Events } \\
\hline 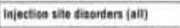 & 385 & 89.9 & 224 \\
\hline Upper respinatery tract intections & 63.6 & 5.1. & 74.5 \\
\hline Heasche & E2: & 6.5 & $\pi 0 t$ \\
\hline FW-the syestams & 513 & \$.! & 307 \\
\hline Fatoun & 35.9 & 521 & 413 \\
\hline Dexusuren & $m$ & 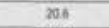 & 29 \\
\hline Fover & 15.8 & 24.9 & $n .7$ \\
\hline Alac pain & 314 & 198 & 24 \\
\hline Myouia & 158 & 269 & 80 \\
\hline Fansea & an & 29 & 245 \\
\hline Imserma & 214 & 188 & 234 \\
\hline Darribenes & 187 & 115 & 100 \\
\hline \multicolumn{4}{|c|}{ Laboratory Teat Abmormulies } \\
\hline Lymponcena & 112 & 201 & 208 \\
\hline Lestopena & Is & 127 & ns \\
\hline Ganubortoperis & $3 x$ & 110 & 152 \\
\hline ASt iscleas & 31 & 10.1 & 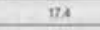 \\
\hline ALT increass & 4 & 198 & 272 \\
\hline
\end{tabular}

For the events in bold. observed diffetences reached statistical signiticance as compare to placebo

The atverse events experienced during the study are listed below, by WHOABI Systern Organ Class. The most common amongst the injection site reactions was in the form mild erythema. The majority of the other injection site reactions were also mild in the Rebif groups. Necrosis was reported in 8 patients treated with Rebit". Two of these patients wete in the $66 \mathrm{mcg}$ weekly and six in the $132 \mathrm{mcg}$ weekly groups. All patien completed the planned treatment period. with only 1 requiring temporary dose reductions and anothes patient stopping trealment tor 2 weeks. Those that required treatment received antibiotics
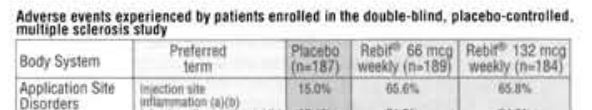

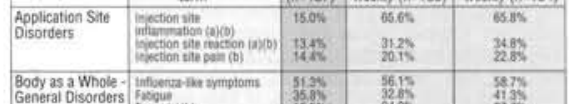

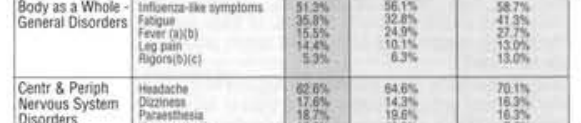

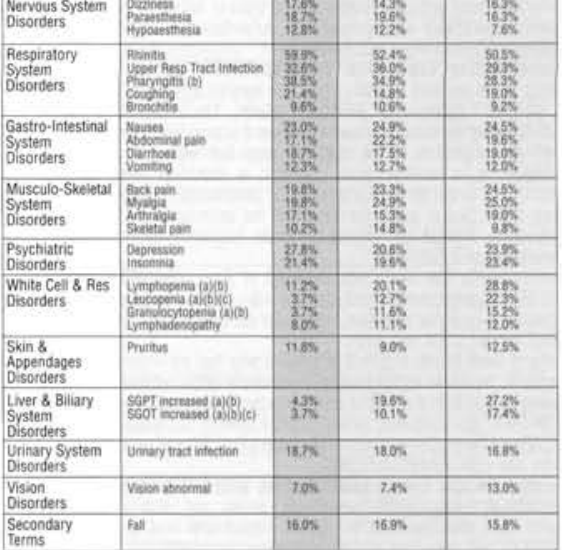

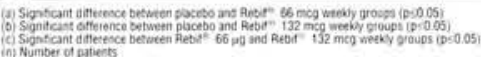

In addition to the above listed adverse events, the following events have been experienced less frequently, in ane or both of the relapsing-remitting multiple sclerosis studies: asithenia, fluid retention, anorexia, gastroenteritis: heariburn, paradentium affections, dental abcess of extraction, stomatitis, glossitis, sleepiness, anxiety. irritability, contusion, lymphadenopatthy, weight gain, bone fracture, dyspnoea, coll sores, fissure at the angle of the mouth, menstrual disorders, cystitis, vaginitis

Immunogenicily: Antibodies to IFN-beta were tested in all patients pre-entry. and at Months 6, 12, 18 and 24. The results of testing for the presence of neutralizing antibodies (NAb) are shown below

Percentage of patients positive for neutralizing antibodies
\begin{tabular}{|c|c|c|}
\hline Placebo & Rebir 66 inco vedily & Rebir 132 mog weekly \\
\hline $0 \%$ & $24 \%$ & $12.5 \%$ \\
\hline
\end{tabular}

Due to concen about the potential impact of neutralizing antibody formation on etficacy. exacerbation counts (primary endpoint) were analysed according to patients' neutralizing antibody status. Over the 2 years of the study, there was no trend to a higher exacebation rate in the neutralizing antibody-positive groups compared to the neutralizin antibody-negative groups. There is no cleat indication that the development of serum neutralizing antibodies allected either salety of efficacy in either of the Rebif groups

\section{Condyloma acuminata}

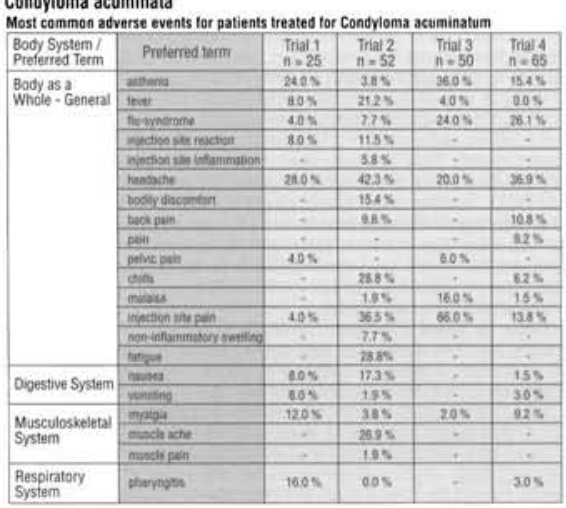

Other adverse events were experienced by less than $5 \%$ of the patients, and inclused eye pain, skin disorder, thinitis, bronchitis, coughing, diarthoea, abdominal pain, postura hypotension, palpitation, vasodilatation, rectal disorder, lymphocytosis, thrombocytopenia delirium, somnolence, joint pain, joint stiftness, lightheadedness, paraesthesia dis tal, disorientation, irritability, sleeplessness, fethargy, bruise. purpura. sweating increased, shorness of breath, upper respiratory tract intection, tactycardia, flushing urethral pain, infection, chest pain, Iymphadenopalhy, PBI increased, arthralgia, dizz. ness, nevvousness, tremor, abnormal vision, vulvovaginal disease, balanitis, penis disease. testis disease. urettritis, infection urinary tract, vaginitis. leukopenia, herpes simplex, prufitis, rash mac pap. skin neoplasia, rash.

Immunogenicity: The determination of the presence of antibodies to human IFN-beta was performed in all 4 studies. A total of four patients had anti beta-interteron antibodies at pre-entry, and 6 other patients had at least a positive result for total binding antibodies at some point during the study. Antibodies were of low flter, and none of the attibodies were neuttralizing to human IFN-beta biological activity.

\section{SYMPTOMS AND TREATMENT OF OVERDOSAGE}

No case of overdose has thus far been described. However, in case of overdosage patients should

\section{DOSAGE AND ADMINISTRATION:}

RELAPSING-REMITTING MULTIPLE SCLEROSIS: The recommended posology Rebift" (Interteron beta-1a) is $22 \mathrm{mog}$ (6MiU) given three times per week by subcuta- nemus iniction. This dose is eftective in the mainotity of patients to delay ptoptession of the disease Patients with a higher degree of disability (an EDSS of 40 or highter) mas) require a dose of 44 magy (12 MUU) $3 \times$ (week

treatment should be initiated under supervision of a plysician experienced in the treatment of the disease. When first starting treatment with Rebif", in order to allow tachyphylaxis to develop thus reducing adverse events, it is recommended that $20 \%$ of the total dose be administered during the initial 2 weeks of theragy. $50 \%$ of total dose be administered in week 3 and 4 , and the full dose trom the fifth week orwarts

At the present time it is not known for how long patients stculled te trealed. Satety and efficacy with Rehit have been demonstrated tollowing 2 years of treatment. Therefore, it is tecommended that patients should be evaluated atter 2 years of treatment with Rebit and a decision for longer-term treatment be made on an individial basis by the treating phiysician

Preparation of Solution: Lyophilized lormulation (Relapsing-Remitting Multiple Sclerosis): Reconstiture the contents of a vial of Ratid with $05 \mathrm{mil}$ of the accompanying sterile diluent isee table below for diluent volume and tesulting concentration). The reconstiuted solution should be used immediatlely

\begin{tabular}{|c|c|c|c|}
\hline \\
\hline Strength & $\begin{array}{l}\text { Volume of Diluent } \\
\text { to be sdded to val }\end{array}$ & $\begin{array}{c}\text { Approximate } \\
\text { avalabile volume }\end{array}$ & $\begin{array}{c}\text { Nominal } \\
\text { concentration mL }\end{array}$ \\
\hline $11 \mathrm{mco}$ (3 MiU) & viste & $0.5 \mathrm{mt}$ & $n$ neg (8) \\
\hline $44 \mathrm{mcg}$ (12 MIU) & 25 atc & $0.5 \mathrm{~mL}$ & $88 \operatorname{mog}(24$ Mivi) \\
\hline
\end{tabular}

Preparation of the solution: liquid formulation: The liquid formulation in a pre-filled syringe is ready lor use. These syringes are graduated to laciltiale therapy initiation. The pre-filled syringes contain $22 \mathrm{mcg}$ and $44 \mathrm{mcg}$ of Rebit respectively. The pre-filled syringes are ready for subculaneous use only.

CONDYLOMA ACUMINATUM: The reconinended posology is $3.67 \mathrm{mcg}$ (1MUU) per

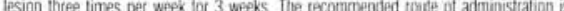
intra-or peri-lesional The pre-filled sycinges are not to be used for this indication Preparation of Solution: Lyophilized formulation (Condyloma acuminatum) Reconstitute the contents of a vial of Rebit in sterile diluent in ordes to obtain a fina concentration of $3.7 \mathrm{mcg}$ per $0.1 \mathrm{~mL}$ solution. The reconstituted solution showid be used immediately

\begin{tabular}{|c|c|c|c|}
\hline \multicolumn{4}{|l|}{ tution Table } \\
\hline Strength & $\begin{array}{l}\text { Volume of Diluent } \\
\text { to be sdood to vias }\end{array}$ & $\begin{array}{l}\text { Approsimate } \\
\text { avaliable volumente }\end{array}$ & $\begin{array}{l}\text { Nominal } \\
\text { concentrationimL }\end{array}$ \\
\hline 11 mog (3 MiU) & Osme- & $0.3 \mathrm{nt}$ & 37 ma0 $(100$ Mut \\
\hline $44 \mathrm{mcg}$ (12 MUU) & $12 \mathrm{~m}$ & $12 \mathrm{mt}$ & 37 msp (100 Miv) \\
\hline
\end{tabular}

COMPOSITION

Lyophilized formulation: Each $3 \mathrm{~mL}$ vial of sterile lyophilized powder contains Interteron beta-1a, albumin (human). mannitol and sodium acelate, as indicated in the table below. Acetic acid and sodium hydroxide are used to adjust the $\mathrm{pH}$

\begin{tabular}{|c|c|c|c|}
\hline Interteron beta- la & Abuinin (Huimin) & Mannitol & Sodium acetate \\
\hline 11 mcg (3 MiU) & $=0$ & 800 & $0.2 \mathrm{mg}$ \\
\hline $44 \operatorname{mcg}(12$ MIU) & 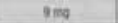 & $\sin$ & $0.2 \mathrm{ng}$ \\
\hline
\end{tabular}

Rebif (Interteron beta-1a) is supplied with a $2 \mathrm{~mL}$ diluent anpoule containing $2 \mathrm{~mL}$ of $0.9 \% \mathrm{NaCl}$ in Water for Injection. No preservatives ase present

\section{Liquid formulation}

The liquid formulation is supplied in syringes containing $0.5 \mathrm{~mL}$ of solution. Each sytinge contains Interferon beta- la, albumin (human), mannitol and $001 \mathrm{M}$ sodiun acelate bufter. as indicated in the table below. The solution does not contain preservatives.

\begin{tabular}{|c|c|c|c|}
\hline interferon beta-1a & Albumin (Huma) & Mannital & Q.01 M Sudium acetats butter \\
\hline 22 mep (6 MiU) & $2 \operatorname{mg}$ & $273 \mathrm{mg}$ & $42 \cos 0$ \\
\hline $44 \mathrm{mcg}$ (12 MiU) & $\operatorname{lm}$ & $n a m p$ & axtopsm. \\
\hline
\end{tabular}

\section{STABILITY AND STORAGE RECOMMENDATIONS}

Lyophilized formulation: Reter to the date indicated on the labels for the expiry date Rebit' (interteron beta- 1a) lyophilized product should be stored at 2-8" C Liquid formulation: Refer to the date indicated on the labels lor the expiry date Rebit" liquid in a pre-filled sytinge should be stored at $2-8^{\circ} \mathrm{C}$. Rebit syringes may be stored tor a linited period at room temperature (up to $25^{\circ} \mathrm{C}$ ). but not more ltan 1 month

\section{RECONSTITUTED SOLUTIONS}

Lyophilized formulation: Lyophilized Rebil" should be reconstituted with 099 $\mathrm{NaCl}$ in Water tor Injection (supplied in $2 \mathrm{~mL}$ neutral glass ampoules containing 20 $\mathrm{mL}$ ). The reconstituted solution should be administered immediately. Although not recommended, it may be used later duting the day of reconstitution it stored in retrigerator $\left(2-8^{\circ} \mathrm{C}\right)$. Do not treeze. The reconstituted solution may have a vellow colouration which is a nomal product characteristic

Liquid formulation: The liquid in the prefilled syringe is reaby for use PARENTERAL PRODUCTS

\section{AVAILABILITY OF DOSAGE FORM}

Rebit" (IIterteron beta-1a) is available in two strengths (11 mcg (3MiU), and 44 mcag (12MiU) per vial), as a hophilized sterile powder -it is aocompanied by diluent $109 \%$ $\mathrm{NaCl}$ in Watet for Injection) in $2 \mathrm{~mL}$ ampoules. Both lyophiilized strengths are supplied in cartons of 1 vial of drug and $1 \times 2 \mathrm{~mL}$ ampoule of diluent. 3 vials of drug and $3 \times 2$ $\mathrm{mL}$ ampoules of diluent, and 12 vials of drug and $12 \times 2 \mathrm{~mL}$ ampoules of diluent Rebif" is also available as a liquid formulation, in prefilled syringes ready for use. Two package strengths are available. $22 \mathrm{mog}$ (6MiU) $0.5 \mathrm{~mL}$ and $44 \mathrm{mcg}$ (12MiU) $0.5 \mathrm{~mL}$ The pre-filled syringes are subplied as single units. 3-packs and 12-packs the preFlled syringes are ready for subcutaneous usse onty

The route of administration tor Relapsing-Remitting Multiple Sclerosis is subculaneous The route of administration for condyloma acuminatum is intra-and peri-tesional. References: 1 The PRISMS (Prevention of Relapses and Disability by Interteron Beta ta in Multiple Sclerosis) Study Group. Randomised double blind placebo-controlled study of interferon B-1a in relapsing/remitting mulliple sclerosis. Lancet, 1998,352 1498-504. 2. Rebif Product Monograph, June 8, 200t. Serono Canatia Inc. 3. IMS Canada Canadian Compusctipt March 2002. Canadian Drugstore and Hospital Audil February 2002

\section{serono}

Q2) Registered tradernark Serono Canada Inc, Oakville, Ontario L.6M 2 G2 


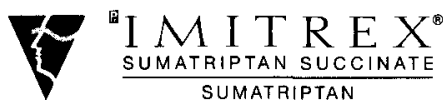

$25 \mathrm{mg}, 50 \mathrm{mg}$ and $100 \mathrm{mg}$ Tablet

$6 \mathrm{mg}$ Subcutaneous Injection and Auttiniector

THERAPEUTIC CLASSIFICATION

\section{PHARMACOLOGIC CLASSIFICATION}

IMDICATIONS AND CLINICAL USES

Mr REX (t) treatment of migraine attacks with or without alt

MITREX $x^{\infty}$ is not tor use in the management of hemiplegic, basilar, or ophthalmoplegic migraine (see CONTRAINDICATIONS). Satety and efficacy have not
been established for cluster headache which is present in arl o oder, predominantly male population.
CONTRAINDICATIONS

MITREX ${ }^{\circ}$ (sumatriptan succinate/sumatriptan) is contraindicated in patients with history, symptoms, or signs of ischemic cardiac, cerebrovascular, or peripheral vascular syndromes, valvular hear
disease or cardiac arrhythmias (especially tachycardias). In addition, patients with other significant underlying cardiovascular addition, patients with other significant underlying cardiovascular
diseases (e.g., atherosclerotic disease, congenilal heart disease) should not receive IMITREX. Ischemic cardiac syndromes include, but are not limited to, angina pectoris of any type (e.g., stable angina of effort and vasospastic forms of angina such as the myocardial ischemia. Cerebrovascular syndromes include, but are mot limited to, strokes of any type as well as transient ischemic attacks (TIAs). Peripheral vascular disease includes, but is not limited to, ischemic bowel dlsease, or Raynaud's syndrome (see WARNINGS).

Because IMiTREX ${ }^{b}$ may increase blood pressure, it is contraindicated in patients with uncontrolled or severe hypertension. of discontinumation of MAO inhibitor therapy is contraindicaled (see PRECAUTIONS: Drug Interactions).

Ergot-containing drugs have been reported to cause prolonged vasossastic reactions. Because IMITRE $X^{8}$ may also cause coronary vasospasm and these effects may be additive, the use of IMITREX
within 24 hours before or after treatment with other $5-H T$, receptor agonists, or ergotamine-containing drugs or their derivatives (eg. dihydroergotamine, methysergidie) is contraindicated.

IMITREX ${ }^{3}$ should not be administered to patients with severe

hepatic impairment.
IMITREX $X^{3}$ is contraindicated in patients with hemiplegic, basilar, or

ophthalmoplegic migraine.
IMITREX is contraindicated in patients with hypersensilivily to sumatriptan or any of the ingredients of the formulations.

MIITREX ${ }^{8}$ Injection should not be given intravenously because of its potential to cause coronary vasospasm.

IMITREX (sumatriptan succinate/sumatriptan) should only be used Whisk of Myocardial lschemia and/or Infarction and Other Adverse Cardiac Events: WirtieX has been associated with transient chest and/or neck pain and tightness which may resemble angina
pectoris. In rare cases, the symptoms have been identified as pectoris. In rare cases, the symptoms have been identified as
being the likely resulf of coronary vasospasm or myocardial ischemia. Rare cases of serious coronary events or arrhythmia
have occurred following use of IMITREX have occurred following use or MITREX. MinREX should not be given to pationts who have documented ischemic or vasospastic
coronary artery disease (CAD) (see CONIRAINDICATIONS). It is strongly recommended that IMITREX $X^{8}$ not be given to patients in whom unrecognized $C A D$ is predicted by the presence of risk factors (e. g., hypertension, hypercholesterolemia, smoking, obesity, (e.g., hypertension, hypercholesterolemia, smoking, obesily,
diabeles, strong family history of CAD, temale who is surgically or physiologically postmenopausal, or male who is over 40 years of clinical evidence that the patient is reasonably free of coronary artery and ischemic myocardial disease or other significant diagnostic procedures to detect cardiovascular disease or predisposition to coronary artery vasospasm is unknown. If, during the cardiovascular evaluation, the patient's medical history or electroconsistent with, coronary artery vasospasm or myocardial
ischemia, IMITREX
CATIONS). For patients with risk factors predictive of $C A D$, who are considered to have a satistactory cardiovascular evaluation, the first dose of IMITREX should be administered in the setting of a physician's
office or similar medically stafled and equipped facility. Because office or similar medically staffed and equipped facility. Because
cardiac ischemia can occur in the absence of clinical symptoms,
consideration should be given to obtaining electrocardiograms in consideration should be given to oblaining electrocardiograms in
patients with risk factors during the interval immediately following patients with risk factors during the interval immodiately
IMITRE $X^{*}$ administration on the first occasion of use. However, an absence of drug-induced cardiovascular effects on the occasion of the initial dose does not preclude the $p$ post

occurring with subsequent administrfaticans. Intermithent long term users of
tactors predictive of CAD, as described above, shouvd receive periodic lactors predictive of CAD, as described above, should receive period
interval cardiovascular gvaluations over the course of trealment. If symptoms consistent with angina occur after the use of IMITAEX", ECG evaluation should be carried out to look for ischemic changes. The systematic approach described above is intended to reduce the likelinood that patients with unrecognized
will be inadvertently exposed to MiTREX

Cardiac Events and Fatalities Associated with 5-HT, Agonists: Mrent can cause coronary artery vasospasm. Serious adverse cardic cardiac nhythm, and death have been reported within a few hours following the agonists in patients with migraine, the incidence of these events is extremely low. The fact that some of these events have occurred in patients with no prio proximity of the events to IMiTR E E K these cases were caused by the drug. In miany cases, however, where there has been known Under lying coronary artery disease, the relationship is uncertain,
Premarketing Exp rerience With IMITRES

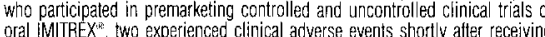
oral IMI JREX" that may have refiected coronorary vasospasm. Neither of these adverse events was associated with a serious clinical outcome

keting the more than 1900 patients with migraine who participated in premar patients who sustained clinical events during or shortly atter receiving pareX that may have reflected coronary artery vasosoasm. Six of these eigh patients had ECG changes consistent with transient ischemia, but withou either findings suggestive of CAD or risk factors predictive of CAD prior to study enrollmen

Among approximately 4,000 patients with migraine who participated in premarketing controlled and unconlrolled clinical trials of IMITREX nasal spray, one subsequent to a cosonary vasospastic event

Postmarketing Experience With IMITREX ${ }^{\$}$ : Serious cardiovascula events, some resulting in death, have been reported in association with the use of IMITREX Injection or IMITREX $X^{\circledast}$ Tablets. The uncontrolled nature of postmarketing surveillance, however, makes it impossible to determine definitively the proportion of the reported cases that were actually caused by
IMITREX or to reliably assess causation in individual cases. On clinica grounds, the longer the latency between the administration of IMITREX ${ }^{\circledR}$ and the Accordingly, interest has focused on events beginning within 1 hour of the

MITREX administration include: coronary artery vasospasm, transien schemia, myocardial infarction, ventricular tachycardia and ventricular fibril

政 ampang reports fromt the USA of serious cardiac events occurring within 1 hou of $C A D$ and the presence of significant underlying CAD was established in most Cerebrovascular Events and Fatalities with 5- $\mathrm{HT}_{1}$ Agonists: Cerebral hemorrhage, subarachnoid hemorrhage, stroke, and other cerebrovascular events have been reported in patients treated with oral or subcutaneous these events is uncertain. In a number of cases, it appears possibie that the

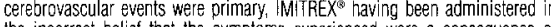
migraine when they headache being experienced is atypical tor the patient. It should also be noted that patients with migraine may be at increased risk of certain cerebrovascular events (e.g., stroke, hemorrhage, TIA). If a patient does not respond to the first
dose, the opportunity should be taken to review the diagnosis beiore a second Special Cardiovascular Pharmacology Studies: In subjects ( $n=10$ ) with suspected coronary artery disease undergoing angiography, a $5-\mathrm{HT}_{1}$ agonist at a subcutaneous dose of $1.5 \mathrm{mg}$ produced an $8 \%$ increase in aortic blood pressure
an $18 \%$ increase in puimonary artery blood pressure and an $8 \%$ increase in an $18 \%$ increase in pulmonary artery blood pressure, and an $8 \%$ increase in systemic vascular resistance. In addition, mild chest pain or tightness was reported by four subjects. Clinically significant increases in blood pressure were experienced by three of the subjects (two of whom also had chest pain/discomfort)
Diagnostic angiogram results revealed that 9 subjects had normal coronary

In an additional siudy with this same drug, migraine patients $(n-35)$ free of
cardiovascular disease were subjected to assessments of myocardial perfusion cardiovascular disease were subjected to assessments of myocardial perfusion
by positron emission tomocraphy while receiving a subcutaneous $1.5 \mathrm{mg}$ dose in the absence of a migraine attack. Reduced coronary vasodilatory reserve $(-10 \%)$, increase in coronary resistance $(-20 \%)$, and decrease in hyperemic the use of the recommended oral doses of this $5-\mathrm{HT}_{1}$ agonist is not known Similar studies have not been done with IMITRE $X^{\circledast}$. However, owing to the common pharmacodynamic actions of 5-HT agonists, the possibility of cardiovascular effects of the nature described above should be considered for any agent of this pharmacological class.

Hypersensitivity: Rare hypersensitivity (anaphylaxis/anaphylactoid) Such reactions can be life threatening or fatal. In general, hypersensitivity reactions to drugs are more likely to occur in individuals with a history of sensitivity to multiple allergens (see CONTRAINDICATIONS). Owing to the possibijity of cross-reactive hypersensitivity reactions, IMITREX ${ }^{*}$ should not be receptor agonists. There have been reports of patients with known hypersersitivity to sulphonamides exhibiting an allergic reaction following administration of :MITREX ${ }^{\circledR}$. Reactions ranged from cutaneous hypersensitivity to anaphylaxis. Other Vasospasm Related Events: $5-\mathrm{HT}$, agonists may cause vasospastic reactions other than coronary artery vasospasm. Extensive post-market experience has shown the use of IMITREX to be associated with rare
occurrences of perioheral vascular ischemia and colonic ischemia with abcominal pain and bloody diarrhea

Increase in Blood Pressure: Signiticant elevation in blood pressure including hypertensive crisis, has been reported on rare occasions in patients with and without a history of hypertension. IMITREX
patients with uncontrolled or severe hypertension (SEe CONTRAINDIicated in patients with uncontrolled or severe hypertension (see CONTRAINDICATIONSS),
In patients with control led hypertension, IMITREX should be administered with In patients with control led hypertension, IMITREX ${ }^{\mathbb{B}}$ should be administered with caution as transient increases in blood pressure and peiph
resistance have been observed in a small portion of patients.

\section{PRECAUTIONS}

Cluster Headache: There is insufficient information on the efficacy and safety of MITREX ${ }^{3}$ (sumatriptan succinate/sumatriptan) in the treatment of cluster
headache, which is present in an older, predominantly mate population. The cend the demand for repeated medication in this Cardiovascular: Discomfort in the chest, neck, throat and jaw (including pain, pressure, heaviness and tightness) has been reported after administration of IMITREX
may cause coronary artery vasospasm, patients who experience signs or symptoms suggestive of angina following IMITREX should be evaluated for the presence of CAD or a predisposition to varian angina before receiving additional doses, and should be monitored electrocardiographically if dosing is resumed and simila symptoms recur. Similarly, patients who experience othe ischemic bowel syndrome or Raynaud's syndrome following IMITREX ${ }^{\circ}$ should be evaluated for atherosclerosis or predisposition to vasospasm (see CONTRAINDICATIONS AND WARNINGS). Neurological Conditions: Care should be taken to exclude other potentialiy serious reurologic conditions before ireating headache in patients not that is atypical for them. There have been rare feports where patients received 5-HT agonists for severe headaches that we'e subsequently shown to have been secondary to an evoving neurologic lesion. For newly diagnosed patients or patients presenting
with atypical symptoms, the diagnosis of migraine should be reconsidered if no response is seen atter the first dose of IMITRE

Seizures: Caution should be observed if IMTTREX is to be used in patients with history of epilepsy or structural brain lesions which lower the convulsion threshold Psychomotor Impairment: Patients should be cautioned that drowsiness
may occur as a result of treatment with IMITREX ${ }^{\oplus}$. They should be advised not to perform skilled tasks (e.g. driving or operating machinery) if drowsiness Renal Impairment: The effects of renal impairment on the efficacy and safety of MTTREX" have not been

in this patient population. safety of IMITREX has not been evaluated, however, the pharmacokinetic profile of sumatriptan in patients with moderate ' hepatic impairment shows that these patients, following an oral dose of $50 \mathrm{mg}$, have much higher plasma sumatriptan concentrations than healthy subjects (Table 2). Theretore,
dose of $25 \mathrm{mg}$ may be considered in patients with hepatic impairment.

Table 2: Pharmacokinetic Paramefers After Oral Administration of IMITREX $50 \mathrm{mg}$ to Healthy Volunteers and Moderately Hepatically mpaired Patients

\begin{tabular}{|cccc|}
\hline $\begin{array}{c}\text { Parameter } \\
\text { (hepatic impaired/healthy) } \\
n=8\end{array}$ & $\begin{array}{c}\text { Mean Ratio } \\
\mathbf{9 0} \% \mathbf{C l}\end{array}$ & p-value \\
\hline AUC $\infty$ & $181 \%$ & $130 t 0252 \%$ & $0.009^{*}$ \\
\hline$C_{\max }$ & $176 \%$ & $12910240 \%$ & $0.007^{*}$ \\
\hline
\end{tabular}

Statistically significant

differ impared statistically between normal volunteers and moderately hepatically with severe hepatic impairment (see CONTRANDICATIONS)

Drug Interactions: Single dose pharmacokinetic drug interaction studies have not shown evidence of interactions with propranolol, flunarizine, pizotiten pharmacokinetics of sumatriptan nasal spray were unaltered when preceded by a single clinical dose of the rasal decongestant xyl ometazoline (0:rivin $\left.{ }^{* 2} 2\right)$. Ergot-Containing Drugs: Ergot-containing drugs have been reported to cause effects being additive, ergot-containing or ergot-type medications (like dihydroergotamine or methysergide) are contraindic

MAO inhibitors. In studies conducted in a imited number of patients, MAO inhibitors reduce sumatriptan clearance, significantly increasing systemic intibitors is contraindicated (see CONTRAINOICATIONS)

Other Seroionergic Drugs. Rare postmarkeling eponts describe patients with weakness, hyperreflexia, and incoordination tollowing the combired use of a MUTRE) sertral ine), tricyclic antidepressant, or other drug with serotonergic activity is clinically warranted, appropriate observation of the patient for acute and longerm adverse events is advised.

agonists has not been evaluated in migraine patients. As an increased risk of coronary vasospasm is a theoreticgl possibility with co-administration of
$5-\mathrm{HT}$, agonists, use of these drugs within 24 hours of each other is

Drug/Laboratory Test Interactions: IMITREX $X^{\text {*n }}$ is not known to interfere with commonly ernployed clinical laboratory tests

Use in Elderly (>65 years): Experience with the use of IMITREX in patients years is not recommended. Sse in Children (<18 years): The satety and efficacy of IMITREX in
children has not been established and its use in this age group is not Use in Pregnancy: Reproduction studies, periormed in rats, have not development due to IMITREX $X^{\boxplus}$. Reptoduction studies, Derformed in rabbits by the oral route, have shown increased incidence of variations in cervico-thoracic biond vesse configuration in the foetuses. These effects were only seen at the highest dose tested, which aftected weight gain in the dams, and at which blood A direct association with IMITREX treatment is considered unl $k$ kely but cannot be excluded. Therefore, the use of IMITREX $X^{\circledast}$ is not recommended in pregnancy. In a rat fertility study, oral doses of IMITREX $X^{*}$ resulting in plasma levels approximately 150 times those seen in humans after a $6 \mathrm{mg}$ subcutaneous dose and approximately 200 times those seen in humans after a $100 \mathrm{mg}$ ora cose were occur during a subcutaneous study where maximum plasma levels achieved imately 150 times those in humans by the oral rout

pregnant women exposed to sumatriptan, a Pregnancy Registry has been established. Physicians are Lactation: Sumatriptan is excreted in human breast milk. Therefore, caution is advised when administering IMITREX ${ }^{\circ}$ to nursing women. Infant exposure can be minimized by avoiding breast feeding for 24 hours after treatment. Binding to Melanin Containing Tissues: In rats treated with a single subcutaneous dose $(0.5 \mathrm{mg} / \mathrm{kg})$ or oral dose $(2 \mathrm{mg} / \mathrm{kg})$ of radiolabeied sumatriptan, the elimination hal life of radioactivity from the eye was 15 and 23 days, respectively, suggesting that sumatriptan and/or its metabolites bind to
the melanin of the eye. Because there could be an accumulation in melanin rich the melanin of the eye. Because there could be an accumulation in melanin rich
tissues over time, this raises the possibility that sumatriptan could cause tissues over time, this raises the possibility that sumatriptan could cause
toxicity in these tissues after extended use. However, no effects on the retina related to treatment with sumatriptan were noted in any of the oral or subcutaneous toxicity studies. Aithough no systematic monitoring of ophthal-
mologic function was undertaken in clinical trials, and no specific recommendations for ophthalmologic monitoring are offered, prescribers should be aware Lossibiliy of long term ophthalmologic effects.

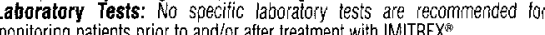
ADVERSE REACTIONS

Serious cardiac events, including some that have been fatal, have occurred following the use of $5-\mathrm{HT}_{1}$ agonists. These events are extremely rare and most have been reported in patients with risk factors predictive of CAD. Events reported have included coronary artery vasospasm, transient myocardial ischemia, myocardial infarction, ventricular tachycardia, and ventricular fibrill
CONTRAINDICATIONS, WAFNINGS, and PRECAUTIONS). Experience in Controlled Clinical Trials with IMITREX

Typical 5-HT 1 Agonist Adverse Reactions: As with other $5-\mathrm{HT}_{1}$ agonists, MTREX (sumatriptan Succinate/sumatriptan) has been associated with These may occur in any part of the body including the chest, throat, neck, jaw and upper limb

Acute Safety: In placebo-controlled migraine trials 7,668 patients received a least one dose of IMITREX (3095 0ral, 1432 subcutaneous, 3141 intranasali). The following tables (Tables 3-5) list adverse events occurring in these trials at
an incidence of $1 \%$ or more in any of the IMIITRE occurred at a higher incidence than in the placebo groups.

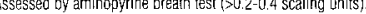

Tradentark of Ciba Self Medication 
Table 3: Treatment-Emergent Adverse Events in Ora Least $1 \%$ of Patients with Migraine
Lerte

\begin{tabular}{|c|c|c|c|c|}
\hline & Placebo & IMITREX & MITREX & IMITREX \\
\hline & & $25 \mathrm{mg}$ & $50 \mathrm{mg}$ & $100 \mathrm{mg}^{\star}$ \\
\hline Number of Patients & 690 & 351 & 723 & 2021 \\
\hline Number of Migraine & & & & \\
\hline A:tacks Treated & 1187 & 945 & 1889 & 14750 \\
\hline $\begin{array}{l}\text { Symploms of Potentially } \\
\text { Cardiac Origin }\end{array}$ & & & & \\
\hline - Chest Sensations* & $0.6 \%$ & $2.3 \%$ & $2.6 \%$ & $3.2 \%$ \\
\hline - Neck/Throat/Jaw Sensations* & $1.4 \%$ & $2.3 \%$ & $3.5 \%$ & $5.2 \%$ \\
\hline - Upper Limb Sensations* & $1.2 \%$ & $1.4 \%$ & $2.5 \%$ & $3.6 \%$ \\
\hline - Palpitations & $0.6 \%$ & $0.3 \%$ & $1.0 \%$ & $1.1 \%$ \\
\hline Neurological & & & & \\
\hline - Head/Face Sensations* & $1.3 \%$ & $2.3 \%$ & $2.5 \%$ & $4.7 \%$ \\
\hline - Dizziness & $2.5 \%$ & $3.1 \%$ & $3.3 \%$ & $6.2 \%$ \\
\hline - Headache & $3.3 \%$ & $4.0 \%$ & $2.2 \%$ & $3.3 \%$ \\
\hline - Vertigo & $0.6 \%$ & $1.1 \%$ & $1.1 \%$ & $1.0 \%$ \\
\hline - Drowsiness & $1.6 \%$ & $1.1 \%$ & $1.2 \%$ & $2.1 \%$ \\
\hline - Tremor & $0.4 \%$ & $0.9 \%$ & $0.4 \%$ & $1.1 \%$ \\
\hline Gastrointestinal & & & & \\
\hline - Nausea & $5.8 \%$ & $2.8 \%$ & $4.4 \%$ & $11.0 \%$ \\
\hline - Hyposalivation & $1.2 \%$ & $1.4 \%$ & $1.1 \%$ & $1.2 \%$ \\
\hline - Vomiting & $2.9 \%$ & $4.3 \%$ & $1.1 \%$ & $4.4 \%$ \\
\hline - Gastrointestinal Discomfort & & & & \\
\hline $\begin{array}{l}\text { \& Pain } \\
\text { - Abdominal Discomiort }\end{array}$ & $1.4 \%$ & $1.1 \%$ & $0.8 \%$ & $2.0 \%$ \\
\hline \& Pain & $0.3 \%$ & NR & $0.4 \%$ & $1.2 \%$ \\
\hline - Diarrhea & $0.9 \%$ & $0.3 \%$ & $0.6 \%$ & $1.1 \%$ \\
\hline Musculoskeletal & & & & \\
\hline - Musculoskeletal Pain & $0.7 \%$ & $2.3 \%$ & $0.4 \%$ & $1.4 \%$ \\
\hline - Muscle Pain & $0.3 \%$ & $0.9 \%$ & $0.1 \%$ & $1.0 \%$ \\
\hline - Muscle Atrophy Weakness & & & & \\
\hline \& Tiredness & NR & $0.6 \%$ & $0.4 \%$ & $1.4 \%$ \\
\hline Ear, Nose \& Throat & & & & \\
\hline - Infections & $0.6 \%$ & $0.6 \%$ & $1.1 \%$ & $1.4 \%$ \\
\hline - Nasal Signs \& Symptoms & $0.7 \%$ & $1.4 \%$ & $0.8 \%$ & $1.0 \%$ \\
\hline - Throat \& Tonsil Symptoms & $0.6 \%$ & $\mathrm{NR}$ & $0.4 \%$ & $2.3 \%$ \\
\hline Respiratory & & & & \\
\hline - Viral Infection & $0.3 \%$ & $1.1 \%$ & $0.1 \%$ & $1.0 \%$ \\
\hline Non-Site Specific & & & & \\
\hline $\begin{array}{l}\text { - Limb Sensations* } \\
\text { - Sensations* }\end{array}$ & $0.4 \%$ & $1.1 \%$ & $0.4 \%$ & \\
\hline (body region unspecified) & $4.5 \%$ & $5.7 \%$ & $8.0 \%$ & $9.0 \%$ \\
\hline - Malaise/Fatigue & $5.1 \%$ & $3.7 \%$ & $2.6 \%$ & $9.5 \%$ \\
\hline - Sweating & $0.4 \%$ & $0.6 \%$ & $0.6 \%$ & $1.6 \%$ \\
\hline
\end{tabular}

"The term "sensations" encompasses adverse events described as pain \& discomfort, pressure, heaviness, constriction, tightness, heat/burning sensation, paresthesia, numbness, tingling, and strange sensation NR = Not Reported

\begin{tabular}{|c|c|c|}
\hline & Placebo & IMITREX ${ }^{\infty} 6 \mathrm{mg}$ \\
\hline Number of Patients & 615 & 1432 \\
\hline Number of Migraine Attacks Treated & 742 & 2540 \\
\hline \multicolumn{3}{|l|}{ Symptoms of Potentially Cardiac Origin } \\
\hline - Chest Sensations* & $1.6 \%$ & $5.7 \%$ \\
\hline - Neck/Throat/Jaw Sensations* & $1.3 \%$ & $12.0 \%$ \\
\hline - Upper Limb Sensations ${ }^{\star}$ & $2.0 \%$ & $6.8 \%$ \\
\hline \multicolumn{3}{|l|}{ Neurological } \\
\hline - Head/Face Sensations* & $3.7 \%$ & $16.6 \%$ \\
\hline - Dizziness & $3.7 \%$ & $7.9 \%$ \\
\hline - Headache & $0.7 \%$ & $3.4 \%$ \\
\hline - Drowsiness & $1.8 \%$ & $2.9 \%$ \\
\hline \multicolumn{3}{|l|}{ Gastrointestinal } \\
\hline - $\quad$ Nausea & $5.9 \%$ & $9.4 \%$ \\
\hline - Hyposalivation & $2.8 \%$ & $3.3 \%$ \\
\hline \multicolumn{3}{|l|}{ Musculoskeletal } \\
\hline - $\quad$ Muscle Atrophy Weakness \& Tiredness & NR & $1.7 \%$ \\
\hline \multicolumn{3}{|l|}{ Ear / Nose and Throat } \\
\hline - $\quad$ Throat \& Tonsil Symptoms & $0.3 \%$ & $1.0 \%$ \\
\hline \multicolumn{3}{|l|}{ Respiratory } \\
\hline - Breathing Discrders & $0.8 \%$ & $1.3 \%$ \\
\hline \multicolumn{3}{|l|}{ Non-Site Specific } \\
\hline - Sensations* (body region unspecified) & $15.9 \%$ & $39.0 \%$ \\
\hline - Injection Site Reactions & $10.4 \%$ & $24.7 \%$ \\
\hline - Limb Sensations* & $1.5 \%$ & $6.0 \%$ \\
\hline - Malaise/Fatigue & $2.3 \%$ & $4.7 \%$ \\
\hline - Sweating & $1.1 \%$ & $1.7 \%$ \\
\hline - Trunk Symiptoms* & $0.5 \%$ & $1.4 \%$ \\
\hline
\end{tabular}

"The term "sensations" encompasses adverse events described as pain \& discomtort, pressure, heaviness, constriction, tightness, heat/burning sensation, paresthesia, numbness, tingling, and strange sensations. $N R=$ Not Reporte
Table 5: Treatment-Emergent Adverse Events in Intranasal Placebo-Controlled Clinical Trials Reported by at Least $1 \%$ of Patients with Migraine

\begin{tabular}{|lcccc|}
\hline & Placebo & IMITREX & IMITREX: \\
& \multicolumn{5}{c|}{$5 \mathrm{mg}$} & $10 \mathrm{mg}$ & $20 \mathrm{mg}^{* *}$ \\
\hline Number of Patients & 741 & 496 & 1007 & 1638 \\
\hline $\begin{array}{l}\text { Number of Migraine } \\
\text { Attacks Treated }\end{array}$ & 1047 & 933 & 1434 & 2070 \\
\hline
\end{tabular}

Symptoms of Potentially

Cardiac Origin

\begin{tabular}{lllll} 
- Chest Sensations $^{\star}$ & $0.3 \%$ & $1.0 \%$ & $0.7 \%$ & $0.6 \%$ \\
\hline
\end{tabular}

- Neck/Throat/Jaw Sensations

$12 \% \quad 0.6 \% \quad 0.7 \% \quad 0.6 \%$

Neurological

- Head/Face Sensations ${ }^{*} \quad 0.8 \% \quad 1.4 \% \quad 2.4 \% \quad 2.4 \%$

\begin{tabular}{lllll} 
- Dizziness & $0.8 \%$ & $1.4 \%$ & $2.4 \%$ & $2.4 \%$ \\
- Headache & $1.2 \%$ & $1.6 \%$ & $1.5 \%$ & $1.2 \%$ \\
\hline
\end{tabular}

\begin{tabular}{lllll} 
- Headache & $0.7 \%$ & $1.4 \%$ & $0.9 \%$ & $0.8 \%$ \\
\hline
\end{tabular}

- Migraine

Gastrointestinal

\begin{tabular}{llll}
$2.6 \%$ & $3.2 \%$ & $2.4 \%$ & $1.8 \%$ \\
\hline
\end{tabular}

- Nausea

$10.4 \% \quad 14.3 \% \quad 9.6 \% \quad 8.3 \%$

- Vomiting

$7.6 \% \quad 11.1 \% \quad 9.6 \% \quad 6.8 \%$

Ear, Nose \& Throat

- Sensitivity to Noise

- Nasal Signs \& Symptoms

$3.1 \% \quad 4.4 \%$

- Intections

$\begin{array}{llll}1.3 \% & 3.0 \% & 1.6 \% & 1.8 \%\end{array}$

$\begin{array}{llll}-0.9 \% & 1.8 \% & 1.3 \% & 0.5 \%\end{array}$

- Uner Respiratory Inflammation $\quad 0.5 \% \quad 1.0 \% \quad 0.6 \% \quad 0.7 \%$

\begin{tabular}{lllll} 
- Throat \& Tonsil Symptoms & $0.8 \%$ & $0.2 \%$ & $1.0 \%$ & $0.7 \%$ \\
\hline
\end{tabular}

\section{Non-Site Specific}

- Sensations*

(body region unspecified)

$1.8 \% \quad 2.4 \% \quad 2.7 \% \quad 2.4 \%$

- Malaise/Fatigue

\begin{tabular}{llll}
$1.3 \%$ & $1.8 \%$ & $1.3 \%$ & $0.8 \%$ \\
\hline
\end{tabular}

\begin{tabular}{lllll} 
- Descriptions of odor or taste $\quad 1.8 \%$ & $15.3 \%$ & $20.2 \%$ & $20.8 \%$ \\
\hline
\end{tabular}

"The term "sensations" encompasses adverse events described as pain \& discomfort, pressure, heaviness, constriction, tightness, heat/burning sensation, paresthesia, numbness, tingling, and strange sensations.

**Includes patients receiving up to 3 doses of $20 \mathrm{mg}$

IMITREX is generally well tolerated. Most of the events were transient in nature and resolved within 45 minutes of subcutaneous administration and within 2

hours of ofal or intranasal administration.
of the 3630 patients treated with MITREX Nasal Spray in clinical trials there was one report of a coronary vasospasm related to IMITREX $X^{\circ}$ administration. Minor disturbances of liver function tests have occasionally been observed with sumatriptan treatment. There is no evidence that clinically significant abnormalities occurred mose frequently with sumatriptan than with placebo. Patients treated with IMITREX rarely exhibit visual disorders like flickering and diplopia. Additionally cases of nystaomus, scotoma and reduced vision have However, visual disorders may also occur during a migraine attack itself.
Hongented.

However, visual disorders may also occu
DOSAGE AND ADMINISTRATION

Genera:

IMITREX ${ }^{\text {B }}$ (sumatriptan succinate/sumatriptan) is indicated for the acute treatment of migraine headache with or without aura. Sumatriptan should not be used prophylactically. Sumalriptan ma be given orally, subcutaneously or as a nasal spray. The safety of treating an average of more th In selecting the appropriate formulation for individual patients, consideration should be given to the patient's preference for formulation and the patient's minutes following subcutaneous injection, 15 minutes following intranasal administration and 30 minutes fo llowing oral administration.

In addition to relieving the pain of migaine sumatriptan (all tormulions)

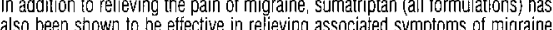
(nausea vomiting effective when admininistered at any stage of a migraine attack. Long term (12-24 months) clinical studies with maximum recommended doses of sumatriptan medication-induced (rebound) headache

Tablets:

The minimal effective single adult dose of IMTREX ${ }^{\star}$ Tablets is $25 \mathrm{mg}$. The maximum recommended single dose is $100 \mathrm{mg}$.

The optimal dose is a single $50 \mathrm{mg}$ tablet. However, depending on individual patient's needs and response to treatment, some patients may require $100 \mathrm{mg}$. Clinical trials have shown that approximately $50-75 \%$ of patients have headache relief within two hours atter oral dosing with $100 \mathrm{mg}$, and that a further $15-25 \%$ have headache relief by 4 hours. Comparator studies have shown similar efficacy rates with the $50 \mathrm{mg}$ and $100 \mathrm{mg}$ tablets. There is evicence that doses of 50 and $100 \mathrm{mg}$ may provide greater effect than $25 \mathrm{mg}$. If the migraine headache returns, or if a patient has a partial response to the
initial dose, the dose may be repeated atter 2 hours. Not more than $200 \mathrm{mg}$ should be taken in any 24 hour period.

it a patient does not respond to the first dose of IMITREX Tablets, a second dose should not be taken for the same attack, as it is unlikely to be of clinical benefit MITREX may be taken to treat subsequent migraine attacks.

The tablet should be swallowed whole with water, not crushed, chewed or split Hepatic Impairment: In patients with mild or moderate hepatic impairmen plasma sumatriptan concentrations up to two times those seen in healthy subjects have beer observed. Therefore, a $25 \mathrm{mg}$ dose (single tablet) may be considered in these patients (see PRECALTinistered to patients with severe hepatic impaiment (see CONTRANDI-

CATIONS).

IMITREX Injection should be injected subcutaneously (on the outside of the thigh or in the upper arm) using an atitoin ector.

The recommended ad uit dose of sumatriptan is a single $6 \mathrm{mg}$ subcutaneous injection. The recommended aduit dose of surnatiptan is a single 6 mg subcutaneous injection.
Clinical trials have shown that approximately $70-72 \%$ of patients have Cinical trials have shown that approximately $70-72 \%$ of patients have
headache relief within one hour after a single subcutaneous injection. This number increases to $82 \%$ by 2 hours.

number increases to $82 \%$ oy 2 hours.
If the migraine headache returns, or it a patient has a partial response to the initial dose, the dose may be sepeated after 1 hour. Not more than $12 \mathrm{mg}$ (two $6 \mathrm{mg}$ injections) should be taken in any 24 hour period.

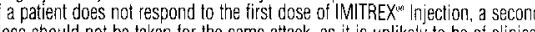
a

Administration during migraine aura prior to other symptoms occurring may Patievent the development of a headache

ints should be advised to read the patient instruction leaflet regarding the sate disposal of syringes and needles.

The minimal effective single adult dose of sumatriptan nasal spray is $5 \mathrm{mg}$. The maximum recommended single dose is $20 \mathrm{mg}$

If the migraine headache returns, or if a patient has a partial response to the initial dose, the dose may be repeated atter 2 hours. Not more than $40 \mathrm{mg}$ should be taken in any 24 hour period

If a patient does not respond to the first dose of IYITREX" Nasal Spray a second dose should not be taken for the same attack, as it is unlikely to be of clinical benefit. IMITREX may be taken for subsequent attacks.

Placebo-controlled clinical trials revealed the following incidence of headache reliet, defined as a decrease in migraine severity from severe or moderate to mild or no pain, within 2 nours atter treatment with intranasal sumatriptan a doses of 5,10 or $20 \mathrm{mg}$ (see Table 6 below).

TABLE 6. Percentage of patients with headache relief at 2 hours

\begin{tabular}{|l|l|ll|ll|ll|}
\hline Study & Placebo (n) & $5 \mathrm{mg}$ & (n) & $\mathbf{1 0} \mathrm{mg}$ & (n) & $20 \mathrm{mg}$ & (n) \\
\hline
\end{tabular}

\begin{tabular}{|l|ll|ll|ll|ll|}
\hline Study $1 \bullet$ & $35 \%$ & $(40)$ & $67 \% \vee$ & (42) & $67 \% \vee$ & (39) & $78 \% \vee$ & (40) \\
\hline
\end{tabular}

\begin{tabular}{|l|ll|ll|ll|ll|}
\hline Study 2- & $42 \%$ & $(31)$ & $45 \%$ & $(33)$ & $66 \% \%^{\prime}$ & (35) & $74 \% \%^{\prime}$ & (39) \\
\hline
\end{tabular}

\begin{tabular}{|l|ll|l|lll|}
\hline Study 3 & $25 \%$ & $(63)$ & $49 \%$ r (122) & $46 \%$ r (115) & $64 \%$ r $\dagger(119)$ \\
\hline
\end{tabular}

\begin{tabular}{|l|c|c|c|c|c|}
\hline Study 4 & $25 \%(151)$ & - & $44 \% \vee(288)$ & $55 \% \vee+(292)$ \\
\hline Study 5 & $32 \%(198)$ & $44 \% \sqrt{2}(297)$ & $54 \% \sqrt{\mathbf{4}}(293)$ & $60 \% \vee+(288)$ \\
\hline
\end{tabular}

\begin{tabular}{|l|l|l|l|l|ll|}
\hline Study 6- & $35 \%(100)$ & - & $54 \% \vee$ & $(106)$ & $63 \% \vee$ & $(202)$ \\
\hline Study $7 \cdot$ & $29 \%(112)$ & - & $43 \%$ & $(109)$ & $62 \% \%^{\prime}$ & $(215)$ \\
\hline
\end{tabular}

Headache re lief was defined as a decrease in headache severity from severe or mocerate to mild or none.

$n=$ total number of patients who received treatment

- comparisons between sumatriptan doses not conducted - comparisons between sumatriptan doses not conducted
$\checkmark p \leq 0.05$ versus placebo t $p \leq 0.05$ versus lower sumatriptan doses
- $p \leq 0.05$ vs $5 \mathrm{mg}$

As shown in the table above, optimal rates of headache relier were seen with the $20 \mathrm{mg}$ dose. Single doses above $20 \mathrm{mg}$ should not be used due to limited satery data and lack of increased efficacy relative to the $20 \mathrm{mg}$ single dose. Within the range of $5-20 \mathrm{mg}$, an increase in dose was not associated with an significant increase in the incidence or severity of adverse events other than taste disturbance (See ADVERSE REACTIONS).

The nasa' spray should be administered into one nostril only. The device is a ready to use single dose unit and must not be primed before administration
Patients should be advised to read the patient instruction leaflet regarding the Patlents should be advised to read the patient instriction
use of the nasal soray device before administration.

USe of the rasal spray device before admin
AVAILABILITY OF DOSAGE FORMS

IMITREX Tablets are availabie as pink $100 \mathrm{mg}$, white $50 \mathrm{mg}$, or white $25 \mathrm{mg}$ ir blister packs are placed in a carton

action ( $6 \mathrm{mg}$; total volume $=0.5 \mathrm{~mL}$ ) is available in pre-filted syringes placed in a tamper-evident carrying case/disposal case. Two pre-filled

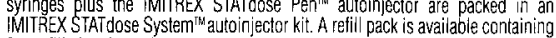
2 pre-filled syringes in a carton.

IMITREX ${ }^{\circledR}$ Injection is also available to physicians or hospitals in a single dose vial ( $6 \mathrm{mg}$; total volume $=0.5 \mathrm{~mL}$ ). There are 5 vials per carton.

in boxes of 6 nasal spray devices

Product Monograph available to physicians and pharmacists upon

Piease contact GlaxoSmithKline Inc., 7333 Miss issauga Road N., Mississauga,

MITREX is a registered trademark, used under license by GlaxoSmithKline Inc. 'WT The appearance, namely the colour, shape, and size of the IMITREX under license by GlaxoSmithKline Inc.

Date of preparation: January 17,1992

Date of revision: February 14,2003

References: 1. Product Monograph of Pr|MITREX (sumatriptan succinate/sumatriptan); GlaxoSmithKline Inc. February 2003. 2. Cady R, McNeal S, O'Quinn S, Putman $G$. Effect of early intervention
with sumatriptan on migraine pain: Retrospective analyses of data from three clinical trials. Clinical Therapeutics 2000;22(9):1035-1048.

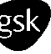
GlaxoSmithKline

GlaxoSmithKline

7333 Mississauga Road North

Mississauga, Ontario L5N 6ட4 


\section{${ }^{\circ}$ COPAXONE (glatiramer acetate injection)}

$20 \mathrm{mg}$, single use vlals and $20 \mathrm{mg} / 1.0 \mathrm{~mL}$, pre-filled syringes for Subcutaneous Injection THERAPEUTIC CLASSIFICATION Immunomodulator

ACTION AND CUNICAL PHARMACOLOGY

COPAXONE' [glatiramer acetate for injection (formerly known as copolymer-1)] is a sterile, lyophilized mixture of synthetic polypeptides containing four naturally occurring amino acids: $\mathrm{L}$-glutamic acid, $\mathrm{L}$-alanine, L-tyrosine and $\mathrm{L}-\mathrm{y}$ sine with an

average molar fraction of $0.141,0.427,0.095$ and 0.338 , respectively.
The mechanism(s) by which glatiramer acetate exerts its effect on Multiple Sclerosis (MS) is (are) not fully elucidated. However, it is thought to act by modifying immune processes that are currently believed to be responsible for the pathogeness of MS. This hypothesis is supported by findings of studies that have been carried out to explore the
pathogenesis of experimental allergic encephalomyelitis (EAE), a condition induced in animals that is generally accepted as an experimental model of MS.

Studies in animals and in vtro systems suggest that upon its administration glatiramer acetate specific suppressor $T$ cells are induced and activated in the periphery.

Because the immunological profile of glatiramer acetate remains to be fully elucidated, concerns exist about is potential to atter naturally occuring immune responses (see PRECAUTIONS).

Pharmacokinetics. Results ootained in pharmacokinetic studies performed in humans (healthy volunteers) and animal: support the assumption that a substantial fraction of the therapeutic dose deivered to patients subculaneously is hydrolyzed fraction of the injected material, eithes intact or partially hydrolyzed, is presumed to enter the lymphatic circulation, enabling it to reach regional lymph nodes, and some, may enter the systemic circulation intact.

Clinical Studies: The efficacy of COPAXONE" (glatiramer acetate for injection) was evaluated in two placebo-controlled trials in patients with Relapsing-Remitting MS (RR.MS). In a third placebo-controlled study the effects of glatiramer acetate on Mil parameters were assessed. In these studies, a dose of $20 \mathrm{mg} / \mathrm{day}$ was used. No other dose or dosing regimen has been studied in placebo-controlled trials of RR-MS.

The first trial was a pilot study Trial 1 (Trial BR-I) which was conducted at a single-center and was a double-blind, randomized, matched-pair, parallel group placebo-controlied trial. Fifty patients with RR-MS were randomized to receive $20 \mathrm{mg} / \mathrm{day}$ glatiramer acetate $(n=25)$ or placebo $(n=25)$ subcutaneously. The protocol-specified primary outcome measure was the proportion of patients who were relapse free during the 2 -year duration of the trial, but two additional relevant outcomes were also specified as endpoints: frequency of attacks during the trial, and the change in the number of attacks compared to the rate of attacks in the 2 years prior to study entry. Results rrom this study (see Table 1) show that there was a statistically significant effect of glatiramer acetate on number of relapses.

TABLE 1 - Trial BR-1: Efficacy Results

\begin{tabular}{|l|c|c|c|}
\hline \multicolumn{1}{|c|}{ Outcome } & \multicolumn{3}{c|}{ Trial $\mathbf{r}$} \\
\hline & $\begin{array}{c}\text { Glatiramer acetate } \\
\mathbf{n = 2 5}\end{array}$ & $\begin{array}{c}\text { Placebo } \\
\mathbf{n = 2 5}\end{array}$ & p-Value \\
\hline \% Relapse Free Patients & $14 / 25(56 \%)$ & $7 / 25(28 \%)$ & 0.085 \\
\hline Mean Relapse Frequency & $0.6 / 2$ years & $2.4 / 2$ years & 0.005 \\
\hline Reduction in Relapse Rate compared to pre-study & 3.2 & 1.6 & 0.025 \\
\hline Median Time to First Relapse (days) & $>700$ & 150 & 0.03 \\
\hline$\%$ of Progression-Free* Patients & $20 / 25(80 \%)$ & $13 / 25(52 \%)$ & 0.07 \\
\hline
\end{tabular}

The primary efficacy measure for Trial I was the proportion of patients who were relapse free during the 2 year duration of the trial (\% Relapse Free). Analyses were based on the intent-to-treat population.

- Progression defined as an increase of at least 1 point on the DSS that persists for at least 3 consecutive months. Trial II (01-9001) was a muticenter double-bind, randomized, placebo-controlled triai. Two hundred and fifty-one patients with RR-MS were randomized to receive $20 \mathrm{mg} /$ day glatiramer acetate $(n=125)$ or placebo $(n=126)$ subcutaneously. Patients were diagnosed with RR-MS by standard criteria, and had at least 2 exacerbations during the 2 years immediately preceding enroliment. Patients had a score of no more than 5 on the Kurtzke Expanded Disablity Scale Score (EDSS), a standard scale ranging from 0 (normal) to 10 (death due to MS). A score of $S$ is defined as one at which a patient is still
ambulatory but for whom full daily activities are impaired due to disability, a score of 6 is defined as one at which the patient is still ambulatory but requires assistance and a score of 7 on this scale means that the patient requires a wheelchair. patients were seen every 3 months for 2 years, as well as within severai days of a presumed exacerbation. In order for an exacerbation to be confirmed, a blinded neurologist had to document objective neurologic signs, as well as document the existence of other criteria (e.g., the persistence of the lesion for at least 48 hours).

The protocol-specified primary outcome measure was the mean number of relapses during treatment. Table 2 shows results of the analysis of primary as well as several secondary outcome measures at two years based on the intent-to-treat population. TABLE 2 - Core (24-month) Double-Blind Study: Effect on Relapse Rate

\begin{tabular}{|l|c|c|c|}
\hline \multicolumn{1}{|c|}{ Outcome } & \multicolumn{3}{c|}{ Trial II } \\
\hline & $\begin{array}{c}\text { Clatiramer acetate } \\
\mathbf{n = 1 2 5}\end{array}$ & $\begin{array}{c}\text { Placebo } \\
\mathbf{n = 1 2 6}\end{array}$ & p-Value \\
\hline Mean No. of Relapses/2 years & 1.19 & 1.68 & 0.055 \\
\hline \% Relapse Free Patients & $42 / 125(34 \%)$ & $34 / 126(27 \%)$ & 0.25 \\
\hline Median Time to First Relapse (days) & 287 & 198 & 0.23 \\
\hline \% of Patients Progression Free & $98 / 125(78 \%)$ & $95 / 126(75 \%)$ & 0.48 \\
\hline Mean Change in EDSS & -0.05 & +0.21 & 0.023 \\
\hline
\end{tabular}

The primary efficacy measure for Trial II was the number of relapses during treatment. Analyses were based on the intent-to-treat population

Baseline adjusted mean

Progression defined as an increase of at least 1 point on the EDSS that persists for at least 3 consecutive months.

The effects of glatiramer acetate on relapse severity were not evaluated in either trit.

Both studies showed a beneficial effect of glatiramer acetate on relapse rate, and on this basis glatiramer acetate is considered effective.

The third study (9003) was a multi-national, muthi-center, MRI-monitored study. A total of 239 patients with RR-MS (119 on glatiramer acetate and 120 on placebo) were randomized. Inclusion criteria were similar to those in Trial II (Study 01-9001) with the additional criteria that patients had to have at least one Gdenhancing lesion on the screening MRL. The patients were treated intially in a double-blind manner for nine months, during which they underwent monthly MRI scanning. The primary endpoint for the double-blind phase was the total cumulative number of TI Cd-enhancing lesions over nine months. Other MR parameters were assessed as secondary endpoints. Table 3 summarizes the results for the parameters monitored during the
nine-month double-blind phase for the intent:-to-treat cohort. Because the link between MR findings and the clinical status of nine-month double-blind phase for the inten:-to-treat cohort. Because the link between MRI fincings an
patients is contentious, the prognostic value of the following statistically significant findings is unknown.

TABLE 3 - Nine-Month Double-Blind Phase: MRI Endpoints - Results

\begin{tabular}{|c|c|c|c|c|}
\hline No. & Outcome & $\begin{array}{c}\text { Glatiramer } \\
\text { acetate } n=113\end{array}$ & $\begin{array}{c}\text { Placebo } \\
n=115\end{array}$ & p-Value \\
\hline \multicolumn{5}{|c|}{ Primary Endpoint } \\
\hline 1. & $\begin{array}{l}\text { Medians of the Cumulative Number of } \mathrm{TI} \\
\text { Gd-Enhancing Lesions }\end{array}$ & 12 & 17 & 0.0037 \\
\hline \multicolumn{5}{|c|}{ Secondary Endpoints } \\
\hline 2. & $\begin{array}{l}\text { Medians of the Cumulative Number of New TI } \\
\text { Cd-Enhancing Lesions }\end{array}$ & 9 & 14 & 0.0347 \\
\hline 3. & Medians of the Cumulative Number of New T2 Lesions & 5 & 8 & 0.01 \\
\hline 4. & $\begin{array}{l}\text { Medians of the Cumulative Change from Baseline } \\
\text { in volumes (mL) of } \mathrm{Tl} \mathrm{Gd} \text {-Enhancing Lesions }\end{array}$ & -0.309 & 0 & 0.0248 \\
\hline s. & $\begin{array}{l}\text { Medians of the Cumulative Change from Baseline } \\
\text { in volumes }(\mathrm{mL}) \text { of } \mathrm{T} 2 \text { Lesions }\end{array}$ & 8.852 & 13.566 & 0.0229 \\
\hline 6. & $\begin{array}{l}\text { Medians of the Cumulative Change from Baseline } \\
\text { in volumes }(\mathrm{mL}) \text { of } \mathrm{T} 1 \text { Hypointense Lesions }\end{array}$ & 1.642 & 1.829 & 0.7311 \\
\hline 7. & Proportion of Tl Gd-Enhancing Lesion-Free Patients & $46.4 \%$ & $32.2 \%$ & 0.0653 \\
\hline
\end{tabular}

INDICATIONS AND CUNICAL USE

For use in ambulatory patients with Relapsing-Remitting Multiple Sclerosis to reduce the frequency of relapses. The safety and efficacy of COPAXONE' in chronic progressive MS have not been established. CONTRAINDICATIONS

COPAXONE" (glatiramer acetate for injection) is contraindicated in patients with known hypersensitivity to glatiramer acetate WARNINCS

The only recommended route of administration of COPAXONE (glatiramer acetate for injection) injection is the subcutaneous route. COPAXONE" should not be administered by the intravenous route

Symptoms of Potentially Cardiac Origin: Approximately $26 \%$ of COPAXONE patients in the pre-marketing multicenter controlled trial (compared to $10 \%$ of placebo patients) experienced at least one episode of what was described as transient chest pain (see ADVERSE REACTIONS: Chest Pain). While some of these episodes occurred in the context of the Immediate Post-Injection Reaction (see ADVERSE REACTIONS: Immediate Post-Injection Reaction), many did not. The pathogenesis of this symptom is unknown. Patients in controlled dinical trials were free of significant cardiovascular problems (New York Heart
Association Class I and in) and thus the risks associated with COPAXONE treatment for Multiple Sclerosis patients with Association Class I and II) and thus the risks
comorbid cardiovascular disease are unknown.

COPAXONE has been associated with an Immediate Post-Injection Reaction consisting of a constellation of symproms appearing immediately after injection that could include flushing, chest pain, palpitations, anxiety, dyspnea, constriction of the throat and urticaria (see ADVERSE REACTIONS: Immediate Post-Injection Reaction).

COPAXONE" has not been studied in patients with a history of severe anaphylactoid reactions, obstructive pulmonary disease or asthma, nor in patients under treatment for either of these two latter conditions. Particular caution is therefore advised regarding the use of COPAXONE' in such patients.

Anaphylactoid reactions associated with the use of COPAXONE" have been reported in rare instances $(<1 / 1000)$ during the post-marketing perio
PRECAUTIONS

Ceneral: Patients should be instructed in aseptic reconstitution and seff-injection techniques to assure the safe administration of COPAXONEs (glatiramer acetate for injection) (see INFORMATION FOR THE PATIENT). The first injection should be performed under the supervision of an appropriately qualified health care professional. Patient understanding and use of aseptic self-injection techniques and procedures should be periodically re-evaluated. Patients should be cautioned against the re-use of needles or syringes and instructed in safe disposal procedures. A puncture-resistant container for disposal of used needles and syringes should be used by the patient. Patients should be instructed on the safe disposal of full containers. Considerations Involving the Use of a Product Capable of Modifving Immune Responses: COPAXONE' is an antigenic
substance and thus it is possible that detrimental host responses can occur with its use. Whether COPAXONE' can alter normal human immune responses, such as the recognition of foreign antigens is unknown. It is therefore possible that treatment with COPAXONE' may undermine the body's defenses against infections and tumor surveillance. Systematic treatment with COPAXONE" may undermine the bodys defenses against infections and tumor survellance. Systematic glatiramer acetate might result in untoward effects.

Glatiramer acetate-reactive antibodies are formed in practically all patients exposed to daily treatment with the recommended dose. Studies in both the rat and monkey have suggested that immune complexes are deposited in the renal

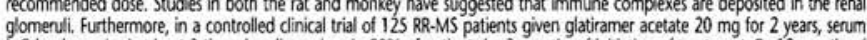
gClevels reached at least 3 times baseline values in $80 \%$ of patients by 3 months of initiation of treatment. By 12 months of treatment, however, $30 \%$ of patients still had $\mathrm{lgC}$ levels at least 3 times baseline values, and $90 \%$ had levels above baseline by 12 months. The antibodies are exclusively of the $\mathrm{lg} \mathrm{C}$ subtype - and predominantly of the $\lg \mathrm{G}$.1 subtype. No $\mathrm{lg} F$ type antibodies could be detected in any of the 94 sera tested. Nevertheless, anaphylaxis can be associated with the administration of almost any foreign substance and, therefore, this risk cannot be excluded.

Preclinical studies to assess the carcinogenic potential of glatiramer acetate in mice and rats do not suggest any evidence of carcinogenic potential related to glatiramer acetate administered subcutaneously at dose levels of up to $30 \mathrm{mg} / \mathrm{kg} / \mathrm{day}$ in rats
and $60 \mathrm{mg} / \mathrm{kg} / \mathrm{day}$ in mice (see TOXICOLOCY: Carcinogenicity). The relevance of these findings for humans is unknown and $60 \mathrm{mg} / \mathrm{kg} / \mathrm{day}$ in mice (see TOXICOLOCY: Carcinogenicity). The relevance of these findings tor humans is unk
(see PRECAUTIONS: Considerations Involving the Use of a Product Capable of Modifying Immune Responses). Drug Interactions: Interactions between COPAXONE: and other drugs have not been fully evaiuated. Results from existing clinical trials do not suggest any significant interactions of COPAXONE with therapies commonly used in MS patients. Th includes the concurrent use of corticosteroids for up to 28 days. COPAXONEs has not been formally evaluated in combination with Interferon beta. However, 246 patients who failed on or who did not tolerate therapy with Interferon beta and were later treated with COPAXONE" within the framework of an open clinical trial did not report any serious or unexpected adverse events thought to be related to treatment.

Use in Pregnancy: There are no adequate and well-controlled studies in pregnant women. No evidence of reproductive toxicity was observed in preclinicai studies (see TOXICOLOCY: Reproduction and Teratology). Because animal reproduction studies are not always predictive of human response, this drug should be used during pregnancy only if clearly needed. During lost to follow-up. Three of the patients electively discontinued pregnancy. Three patients stopped treatment 1, 1.5 and 2 months after learning they were pregnant; all delivered healthy babies.

Nursing Mothers: It is not known whether this drug is excreted in human milk. Because many drugs are excreted in human milk, treating a nursing woman with COPAXONE' should only be considered after careful risk/benefit assessment and be used with caution.

Use in Children: The safety and effectiveness of COPAXONE' have not been established in individuals below 18 years of age. Use in the Elderly: COPAXONE" has not been studied in the elderly ( $>65$ years old).

Use in Patients with Impaired Renal Function: The pharmacokinetics of COPAXONE' in patients with impared rena unction have not been determined.

ADVERSE REACTIONS

In the pre-marketing clinical trials, approximately 900 individuals have received at least one dose of COPAXONE" (glatirame acetate for iniection) in controlled and uncontrolled clinical trials. Total patient exposure to COPAXONE" in clinical trials ranged from 6 months (693 patients) to 2 years ( 306 patients), and to over 7 years ( 69 patients) at a daily dose of $20 \mathrm{mg}$.

In controlled dinical trials, the most commonly observed adverse events associated with the use of COPAXONE" which occurred at a higher frequency than in placebo treated patients were: injection site reactions, vasodilation, chest pain thenia, infection, pain, nausea, arthralgia, anxiety and hypertonia

Of a total of 844 patients who could be evaluated for safety, approximately $8 \%$ discontinued treatment due to an adverse event The adverse events most commonly associated with discontinuation were: injection site reaction (6.5\%), vasodilation, unintended pregnancy, depression, dyspnea, urticaria, tachycardia, dizziness and tremor. Treatment

discontinuation due to a serious adverse

Immedlate Post-Injection Reaction: Approximately $10 \%$ of Multiple Sclerosis patients exposed to COPAXONE in pre-marketing studies reported a post-njection reaction immediately following subcutaneous injection of COPAXONE symptoms experienced could include flushing, chest pain, palpitations, anxiely, dyspnea, constriction of the throat and urticaria. These symptoms were invariably transient, self-limited, did not require specific treatment and in general, arose several months after initiation of treatment, although they may occur earlier in the course of treatment. A given patient may experience one or several episodes of these symptoms during treatment with COPAXONE?. Whether these episodes are mediated by an immunologic or non-immunologic mechanism, and whether several similar episodes seen in a given patient have identical mechanisms is unknown. In fact, whether or not this constellation of symptoms actually represents specific syndrome is unknown. During the post-marketing period, there have been reports of patients with simila symptoms who received emergency medical care (see WARNINCS).

Chest Pain: Approximately $26 \%$ of glatiramer acetate patients in the multicenter pre-marketing controlled trial (compared to $10 \%$ of placebo patients) experienced at least one episode of what was described as transient chest pain. While some of these episodes occurred in the context of the Immediate Post-Injection Reaction described above, many did not. The temporal relationship of the chest pain to an injection of glatiramer actate was not always known, although the pain was transient (usually lasting only a few minutes), often unassociated with other symptoms, and appeared to have no important clinical sequelae Some patients experienced more than one such episode, and episodes usually began at least 1 month after the initiation of treatment. The pathogenesis of this symptom is unknown. There has been onily one episode of chest pain during which a full ECC was performed; the ECC showed no evidence of ischemia. Patients in clinical trials were free of significant cardioascular disease (New York Heart Association Class I or in: therefore, the risks associated with olatiramer acetate treatment for Mutiple Sclerosis patients with comorbid cardiovascular disease are unknown (see WARNINCS: Symptoms of Potentially Cardiac Origin).

Table 4 lists the adverse experiences after up to 35 months of treatment ( $>27.33$ months: COPAXONEe, $n=84$; Placebo $n=75$; $>33$ months: COPAXONE, $n=12$; Placebo, $n=24)$ in the pre-marketing multicenter placebo-controlled study (Trial II) in relapsing-remitting Multiple Sclerosis patients that occurred at an incidence of at least $2 \%$ among patients who received COPAXONE" and at an incidence that was at least $2 \%$ more than that observed in the same trial for placebo patients regardless of their causal relationship to treatment. No laboratory adverse experiences that met these criteria were reported.

It should be noted that the figures cited in Table 4 cannot be used to predict the incidence of side effects during the course o usual medical practice, where patient characteristics and other factors differ from those that prevaled in the clinical trials. However, the cited figures do provide the prescribing physician with some basis for estimating the relative contribution of drug and non-drug factors to the adverse event incidence rate in the population studied. 
TABLE 4

Pre-marketing Controlled Trial in Patients with Multiple Sclerosis Adverse Experiences $\geq 2 \%$ Incidence and $\geq 2 \%$ Above Placebo

\begin{tabular}{|c|c|c|c|c|}
\hline \multirow[b]{2}{*}{ Adverse Experience } & \multicolumn{2}{|c|}{$\begin{array}{c}\text { COPAXONE } \\
n=125\end{array}$} & \multicolumn{2}{|c|}{$\begin{array}{c}\text { Placebo } \\
n=126\end{array}$} \\
\hline & $\mathbf{n}$ & $\%$ & $\mathbf{n}$ & $\%$ \\
\hline $\begin{array}{l}\text { Body as a Whole } \\
\text { Injection Site Pain } \\
\text { Asthenia } \\
\text { Injection Site Erythema } \\
\text { Injection Site Pruritus } \\
\text { Flu syndrome } \\
\text { Injection Site Inflammation } \\
\text { Back pain } \\
\text { Chest pain } \\
\text { Injection Site Mass } \\
\text { Injection Site Induration } \\
\text { Injection Site Welt } \\
\text { Neck pain } \\
\text { Face Edema } \\
\text { Injection Site Urticaria } \\
\text { Injection Site Hemorrhage } \\
\text { Chills } \\
\text { Cyst } \\
\text { Injection Site Reaction } \\
\text { Injection Site Atrophy } \\
\text { Abscess }\end{array}$ & $\begin{array}{l}83 \\
81 \\
73 \\
48 \\
38 \\
35 \\
33 \\
33 \\
33 \\
25 \\
19 \\
16 \\
11 \\
9 \\
8 \\
5 \\
5 \\
4 \\
3 \\
3 \\
\end{array}$ & $\begin{array}{l}66.4 \\
64.8 \\
58.4 \\
38.4 \\
30.4 \\
28.0 \\
26.4 \\
26.4 \\
26.4 \\
20.0 \\
15.2 \\
12.8 \\
8.8 \\
7.2 \\
6.4 \\
4.0 \\
4.0 \\
3.2 \\
2.4 \\
2.4\end{array}$ & $\begin{array}{c}46 \\
78 \\
17 \\
5 \\
34 \\
9 \\
28 \\
13 \\
10 \\
1 \\
5 \\
9 \\
2 \\
0 \\
4 \\
1 \\
1 \\
1 \\
0 \\
0\end{array}$ & $\begin{array}{c}36.5 \\
61.9 \\
13.5 \\
4.0 \\
27.0 \\
7.1 \\
22.2 \\
10.3 \\
7.9 \\
0.8 \\
4.0 \\
7.1 \\
1.6 \\
0 \\
3.2 \\
0.8 \\
0.8 \\
0.8 \\
0 \\
0\end{array}$ \\
\hline $\begin{array}{l}\text { Cardiovascular } \\
\text { Vasodilatation } \\
\text { Palpitation } \\
\text { Migraine } \\
\text { Syncope } \\
\end{array}$ & $\begin{array}{l}34 \\
14 \\
9 \\
8 \\
\end{array}$ & $\begin{array}{l}27.2 \\
11.2 \\
7.2 \\
6.4 \\
\end{array}$ & $\begin{array}{l}14 \\
6 \\
5 \\
4 \\
\end{array}$ & $\begin{array}{l}11.1 \\
4.8 \\
4.0 \\
3.2\end{array}$ \\
\hline $\begin{array}{l}\text { Digestive } \\
\text { Nausea } \\
\text { Vomiting } \\
\text { Anorexia } \\
\text { Castroenteritis } \\
\text { Oral Moniliasis } \\
\text { Tooth Caries } \\
\end{array}$ & $\begin{array}{c}29 \\
13 \\
6 \\
6 \\
3 \\
3 \\
\end{array}$ & $\begin{array}{l}23.2 \\
10.4 \\
4.8 \\
4.8 \\
2.4 \\
2.4\end{array}$ & $\begin{array}{l}22 \\
7 \\
3 \\
2 \\
0 \\
0\end{array}$ & $\begin{array}{c}17.5 \\
5.6 \\
2.4 \\
1.6 \\
0 \\
0\end{array}$ \\
\hline $\begin{array}{l}\text { Hemic and Lymphatic } \\
\text { Lymphadenopathy } \\
\text { Ecchymosis }\end{array}$ & $\begin{array}{l}23 \\
15 \\
\end{array}$ & $\begin{array}{l}18.4 \\
12.0 \\
\end{array}$ & $\begin{array}{l}12 \\
12\end{array}$ & $\begin{array}{l}9.5 \\
9.5 \\
\end{array}$ \\
\hline $\begin{array}{l}\text { Metabolic and Nutritional } \\
\text { Peripheral Edema } \\
\text { Weight gain } \\
\text { Edema }\end{array}$ & $\begin{array}{l}14 \\
7 \\
5\end{array}$ & $\begin{array}{l}11.2 \\
5.6 \\
4.0\end{array}$ & $\begin{array}{l}7 \\
0 \\
1 \\
\end{array}$ & $\begin{array}{l}5.6 \\
0 \\
0.8\end{array}$ \\
\hline $\begin{array}{l}\text { Musculo-Skeletal } \\
\text { Arthralgia }\end{array}$ & 31 & 24.8 & 22 & 17.5 \\
\hline $\begin{array}{l}\text { Nervous System } \\
\text { Hypertonia } \\
\text { Tremor } \\
\text { Agitation } \\
\text { Confusion } \\
\text { Nystagmus }\end{array}$ & $\begin{array}{l}44 \\
14 \\
7 \\
5 \\
5 \\
\end{array}$ & $\begin{array}{l}35.2 \\
11.2 \\
5.6 \\
4.0 \\
4.0\end{array}$ & $\begin{array}{l}37 \\
7 \\
4 \\
1 \\
2 \\
2\end{array}$ & $\begin{array}{l}29.4 \\
5.6 \\
3.2 \\
0.8 \\
1.6\end{array}$ \\
\hline $\begin{array}{l}\text { Respiratory } \\
\text { Rhinitis } \\
\text { Dyspnea } \\
\text { Bronchitis }\end{array}$ & $\begin{array}{l}29 \\
23 \\
18\end{array}$ & $\begin{array}{l}23.2 \\
18.4 \\
14.4\end{array}$ & $\begin{array}{c}26 \\
8 \\
12 \\
\end{array}$ & $\begin{array}{l}20.6 \\
6.4 \\
9.5 \\
\end{array}$ \\
\hline $\begin{array}{l}\text { Skin and Appendages } \\
\text { Sweating } \\
\text { Erythema } \\
\text { Skin Disorder } \\
\text { Skin Nodule } \\
\text { Wart }\end{array}$ & $\begin{array}{l}15 \\
8 \\
5 \\
4 \\
3\end{array}$ & $\begin{array}{l}12.0 \\
6.4 \\
4.0 \\
3.2 \\
2.4\end{array}$ & $\begin{array}{l}10 \\
4 \\
2 \\
1 \\
0\end{array}$ & $\begin{array}{c}7.9 \\
3.2 \\
1.6 \\
0.8 \\
0\end{array}$ \\
\hline $\begin{array}{l}\text { Special Senses } \\
\text { Ear Pain } \\
\text { Eye Disorder }\end{array}$ & $\begin{array}{c}15 \\
8\end{array}$ & $\begin{array}{c}12.0 \\
6.4\end{array}$ & $\begin{array}{c}12 \\
1\end{array}$ & $\begin{array}{l}9.5 \\
0.8\end{array}$ \\
\hline $\begin{array}{l}\text { Urogenital System } \\
\text { Urinary Urgency } \\
\text { Vaginal Moniliasis } \\
\text { Dysmenorrhea } \\
\text { Unintended Pregnancy } \\
\text { Impotence }\end{array}$ & $\begin{array}{l}20 \\
16 \\
12 \\
4 \\
3\end{array}$ & $\begin{array}{l}16.0 \\
12.8 \\
9.6 \\
3.2 \\
2.4\end{array}$ & $\begin{array}{l}17 \\
9 \\
9 \\
0 \\
0\end{array}$ & $\begin{array}{c}13.5 \\
7.1 \\
7.1 \\
0 \\
0\end{array}$ \\
\hline
\end{tabular}

Other events which occurred in at least $2 \%$ of patients but were present at equal or greater rates in the placebo group included: Body as o whole: Headache, injection site ecchymosis, accidental iniury, abdominal pain, allergic thinitis and malaise Digestive System: Dyspepsia, constipation, dysphagia, fecal incontinence, flatulence, nausea and vomiting, gastritis, gingivitis, periodontal abscess, and dry mouth. Musculo-Skeletal: Myasthenia and myalgia. Nervous System: Dizziness, hypesthesia, paresthesia, insomnia, depression, dysesthesia, incoordination, somnolence, abnormal gait, amnesia, emotional lability, Lhermitte's sign, abnormal thinking, twitching, euphoria, and sleep disorder. Respiratory System: Pharyngitis, sinusitis, increased cough and laryngitis. Skin and Appendoges: Acne, alopecia, and nail disorder. Special Senses: Abnormal vision, diplopia, amblyopia, eye pain, conjunctivitis, tinnitus, taste perversion, and deafness. Urogenital System: Urinary tract infection, urinary frequency, urinary incontinence, uninary retention, dysuria, cystitis, metrormagia, breast pain, and vaginitis. Data on aderse ent clinically significant dilserences were identiled. In these clnical thals between the ages of 18 and 45 . Consequently, inadequate data are available to perform an analysis of the incidence of adverse events related to clinically relevant age subgroups.

Laboratory analyses were performed on all patients participating in the clinical program for COPAXONE". Clinically significant changes in laboratory values for hematology, chemistry, and urinalysis were similar for both COPAXONE⿱ ${ }^{\circ}$ and placebo groups changes in laboratory values for hematology, chemistry, and urinalysis were similar tor both COPAXONE" and placebo groups
in blinded clinical trials. No patient receiving COPAXONE" withdrew from any trial due to abnormal laboratory findings.

Other Adverse Events Observed During All Clinkal Triols

COPAXONE has been administered to approximately 900 individuals during clinical trials, only some of which were placebocontrolled. During these trials, all adverse events were recorded by clinical investigators using terminology of their own choosing. To provide a meaningful estimate of the proportion of individuals having adverse events, similar types of events were grouped into a smaller number of standardized categories using COSTART II dictionary terminology. All reported events that occurred at least twice and potentially important events occurring once, are included except those already listed in the orevious table, those too general to be informative, trivial events, and other events which occurred in at least $2 \%$ of treated patients and were present at equal ar greater rates in the placebo group.

Events are further classified within body system categories and enumerated in order of decreasing frequency using the following definitions: Frequent adverse events are defined as those occurring in at least $1 / 100$ patients; infrequent adverse events are those occurring in 1/100 to 1/1000 patients, Body as a whole: frequent: injection site edema, injection site atrophy, abscess and injection site hypersensitivity Intrequent: Injection site hematoma, injection site fibrosis, moon face cellu. phy, a biseess site melanosis, lipoma and photosensitivity reaction Cardiovascular frequent Hypertension, infrequent Hypotension, midsystolic click, systolic murmur, atrial fibrillation, bradycardia, fourth heart sound, postural hypotension and varicose vein Digestive: intrequent: Dry mouth, stomattitis, burning sensation on tongue, choiecryttis, colitis, esophageal ulcer, esophagit gastrointestinal carcinoma, gum hemorhage, hepatomegaly, increased apoetite, melena, mouth ulceration, pancreas disorder pancreatitis, rectal hemorrhage, tenesmus, tongue discolouration and duodenal uleer, Endocrine: Infrequent: Coiter, hyperthyroidism, and hypothyroidism. Gastrointestinal: Frequent: Bowel urgency, oral moniliasis, salivary gland enlargement, tooth caries, and ukcerative stomatitis. Hemic and Lymphatic Infrequent: Leukopenia, anemia, cyanosis, eosinophilia hemateme sis, Iymphedema, pancytopenia, and splenomegaly. Metabolic and Nutritional: Infrequent: Weight loss, accohol intolerance, Cushing's syndrome, gout, abnormal healing, and xanthoma. Musculoskeletal: Infrequent: Arthritis, muscle atrophy, bon pain, bursitis, kidney pain, muscle disorder, myopathy, osteomyelitis, tendon pain, and tenosynovitis. Nervous: Frequent: Abnormal dreams, emotional lability, and stupor. Infrequent: Aphasia, ataxia, convulsion, circumoral paresthesia, depersonalization, hallucinations, hostility, hypokinesia, coma, concentration disorder, facial paralysis, decreased libido, manic reac
Respiratory: frequent: Hyperventilation, hay-fever. intrequent: Asthma, pneumonia, epistaxis, hypoventilation, and voice skin hypertophy Appendages: Frequent: Eczema, herpes zoster, pustular rash, skin atrophy and warts. Intrequent. Dry skin,

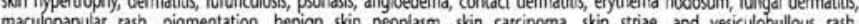
Special Senses: Frequent. Visual field defect infrequent. Dry eves, otitis externa ptosis, cataract, corneal ulcer mydrasis optic

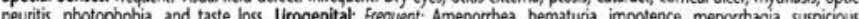
Papanicolaos smear , ar engorgement, breast enlargement breast pain carcinoma cervix in situ, fibrocystic breast, kidney calculs, nocturia, onate cyst, priapism, pyelonephritis, abnormal sexual function, and urethritis.

\section{Adverse Events Reported Post-Marketing and Not Previously Noted in Clinical Trials}

Post-marketing experience has shown an adverse event profile similar to that presented above. Reports of adverse reactions occurring under treatment with COPAXONE" (glatiramer acetate for injection) not mentioned above, that have been Body as a whole: Sepsis, LE syndrome, hydrocephalus, enlarged abdomen, inection site hypersensitvity allergic reaction anaphylactoid resction, bacterial infection, fever, infection. Cardiovascular: Thrombosis, perioneral vascular disease, pericardia effusion, myocardial infarct, deep thrombophlebitis, coronary occlusion, congestive heart failure, cardiomyopathy cardiomegaly, arthyyhmia, angina pectoris, tachycardia. Digestive: Tongue edema, stomach uicer hemornhage, liver function abnormality, Iver damage, hepatitis, efuctation, cirrhosis of the Iiver, cholelathiasis, diarthea, gastrointestinal disorder Hemic and Lymphatic: Thrombocytopenia, lymphoma-like reaction, acute leukemia. Metabolic and Nutritionat: Hypercholesteremia. Musculoskeletal: Rheumatoid arthritis, generalized spasm. Nervous: Myelitis, meningitis, CNS neoplasm, cerebrovastular accident, brain edema, abnormal dreams, aphasia, convulsion, neuralgia, anxiety foot drop, nervousness, speech disorder, vertigo. Respiratory: Pulmonary embolus, pleural effusion, carcinoma of lung, hay fever, laryng smus. Skin and Appendages: Herpes simplex, pruritis, rash, urticaria. Special Senses: Claucoma, blindness, visual fiéd defect. Urogenital: Urogenital neoplasm, urine abnormality, ovarian carcinoma, nephrosis, kidney failure, breast carcinoma, bladder carcinoma, urinary treguenchy

\section{SYMPTOMS AND TREATMENT OF OVERDOSAGE}

Overdose with COPAXONE has been reported in three patients. One patient injected four doses ( $80 \mathrm{mg}$ total) of COPAXONE" at once. No sequelae were noted. Two other patients, a 28-year old mae and a 37.year old female, were given 3 inections of $20 \mathrm{mg}$ of COPAXONE's at one half hour intervals by error. Neither patient evidenced any change in blood pressure, heart rate, or temperature. Telephone follow-up several hours later produced no report of adverse experiences from either patient.

COPAXONE" should only be prescribed by (or following consultation with) clinicions who are experienced in the diagnasis and man. agement of Multipie Sclerosis.

The recommended dose of COPAXONE' (glatiramer acetate for injection or glatiramer acetate injection) for the treatment of relapsing-remitting MS is a daily injection of $20 \mathrm{mg}$ given subcutaneously.

Instructions for Use: To reconstitute lyophilized COPAXONE' for injection, use a sterle syringe and adapter to transfer $1.1 \mathrm{~mL}$ of the cilvent supplied, Sterile Water for Injection, into the COPAXONE' vial. Cently swirt the vial of COPAXONE" and let stand at room temperature until the solid material is completely dissolved. Inspect the reconstituted product visually and discard or return the product to the pharmacist before use if it contains particuate matter. Use within 8 hours after reconstitution. Withdraw $1.0 \mathrm{~mL}$ of the solution into a sterle syringe. Remove the adapter, connect a 27-gauge needle and inject the solution subcutaneously. Sites for self-injection include arms, stomach (abdomen), buttocks, and thighs. A vial is suitzble for single use only; unused portions should be discarded (see INFORMATION FOR THE PATIENT: Reconstituted product)

For the pre-filled syringe of COPAXONE, please see the INFORMATION FOR THE PATIENT: pre-filled syringe for instructions on the preparation and injection of COPAXONE:

\section{Drug Substance:}

Clatiramer acetate

Chemical Name: Clatiramer acetate is the acetate salt of synthetic polypeptides.

Description: Glatiramer acetate is prepared by chemically reacting the activated derivatives of four amino acids: -glutamic acid (L-Clu), L-alanine (L-Ala), L-tyrosine (L-Tyr), and L-Dysine (L-Lys) in a specified ratio. The molar fraction of each amino acca resdue ranges as hallow: LClu 0.129.0.153, L.Ala 0.392-0.462,

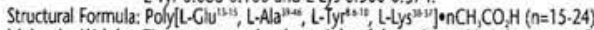

Molecular Weight: The average molecular weight of the polypeptide is between 4,700 and 11,000 daltons, with at least 68 Physical form: Whit to slightly yellowish lyoph $\quad$

Physical Form: White to slightly yellowish lyophilized material.

Solubility: $\quad$ Sparingly soluble in water, insoluble in acetone.
$\mathrm{pH}$ :

Composition: COPAXONE" (glatiramer acetate for injection) is a sterie, yophilized drug product, intended for subcutareous injection following reconstitution with Sterile Water for Injection. Each vial of lyophilized drug product contains $20 \mathrm{mg}$ glatiramer acetate, plus a $2 \mathrm{mg}$ overage 10 allow for losses in reconstitution and transfer and $40 \mathrm{mg}$ mannito. Each vial of Sterile Water for Injection contains $1.1 \mathrm{~mL}$ of Sterile Water for Injection plus a $0.35 \mathrm{~mL}$ overage to allow for losses in reconstitution and transfer.

COPAXONE' (glatiramer acetate injection) is a single-use $20 \mathrm{mg} / 1.0 \mathrm{~mL}$ pre-filled syringe containing a sterile solution equivalent with the COPAXONE" reconstituted solution (ie., $20 \mathrm{mg} / \mathrm{mL}$ glatiramer acetate and $40 \mathrm{mg}$ mannito in sterile water for injection). Stability and Storage Recommendations: Vials of lyoph ilzed COPAXONE" should be stored under refrigeration $\left(2^{2} \cdot 8^{\circ} \mathrm{C}\right.$ ). COPAXONË may also be stored at room temperature $\left(15^{\circ}-30^{\circ} \mathrm{C}\right)$ for up to 14 days. The vials of diluent (Sterile Water for injection) should be stored at room temperature.

The pre-filled syringes of COPAXONE' should be refrigerated immediately upon receipt (between $2^{\circ}-8^{\circ} \mathrm{C}$ ). DO NOT FREEZE. If you cannot have refrigerator storage, pre-filled syringes of COPAXONE" can be stored at room temperature $\left(15^{\circ}-30^{\circ} \mathrm{C}\right)$ for up to one week. Do not store pre-filled syringes at room temperature for longer than one week. Note: this drug is Light sensitive, do not expose to light when not injecting. Each pre-filed syringe is for single use only.

Reconstituted Solutions: To reconstitute lyophilized COPAXONE', prior to injection, use a sterile syringe and adapter to transfer the diluent supplied, Sterile Water for linjection, into the COPAXONEe vial. Gently swir the vial of COPAXONE' and let stand at room temperature until the solid material is completely dissolved. Inspect the reconstituted product visually and discard or return the product to the phamacist if it contains particulate matter. Soon after the product is completely dissolved, withdraw $1.0 \mathrm{~mL}$ of the solution into a sterile syringe. Remove the adapter, connect a 27 .gauge needle and inject the solution subcutaneously. A vial is suitable for single use only; unused portions should be discarded. The reconstitute Parenteral Products: COPAXONE" should be reconstituted only with the provided diluent, Sterile Water for Injection.

\begin{tabular}{|c|c|c|c|}
\hline Vial Size & $\begin{array}{c}\text { Volume of Diluent } \\
\text { to be Added }\end{array}$ & $\begin{array}{c}\text { Volume to be } \\
\text { Injected }\end{array}$ & $\begin{array}{c}\text { Nominal } \\
\text { Concentration per } \mathrm{mL}\end{array}$ \\
\hline $2 \mathrm{~mL}$ & $1.1 \mathrm{~mL}$ & $1.0 \mathrm{~mL}$ & $20 \mathrm{mg}$ \\
\hline
\end{tabular}

\section{AVAILABIUTYY OF DOSAGE FORMS}

COPAXONE" (giatiramer acetate for injection) is supplied as a $20 \mathrm{mg}$ dose of sterile lyophilized glatiramer acetate with mannitol, packaged in single use $2 \mathrm{~mL}$ amber vials. A separate vial, containing $1.1 \mathrm{~mL}$ of diluent (Sterile Water for Injection) plus $0.35 \mathrm{~mL}$ of overage of diluent is included in the Self Injection Administration Package for each vial of drug. COPAXONE" The diluent (Sterile Water for injection) for COPAXONE" is supplied in packs of 32 clear vials and is located in the Self Iniection Administration Package

COPAXONE' (glatiramer acetate injection) is a single-use $20 \mathrm{mg} / 1.0 \mathrm{~mL}$ pre-filled syringe containing a sterile solution equivalent iniection). COPAXONE" (glatiramer acetate iniection) is available in packs of 30 single-use $20 \mathrm{mg} / 1.0 \mathrm{~mL}$ pre-filled glass syring with 33 alcohol preps (swabs).

\section{REFERENCES}

1. COPAXONE" (glatiramer acetate) Product Monograph, Teva Neuroscience.

Product monograph available upon request.

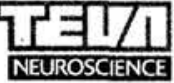

Teva Neuroscience

de Maisonneuve West, Suite 550

Montreal, Quebec H3A 3L4 


\section{COPAXONE (acétale de glatiramère injectable)}

$20 \mathrm{mg}$, flacons unidoses et $20 \mathrm{mg} / 1,0 \mathrm{~mL}$, seringues préremplies pour injection sous-cutanée CLASSIFICATION THÉRAPEUTIQUE Immunomodulateur ACTION ET PHARMACOLOCIE CLINIQUE

COPAXONE* [acétate de glatiramère pour injection (connu auparavant sous le nom de copolymère1)] es un mélange lyophilise stérile de polypeptides synthétiques renfermant quatre acides aminés naturels:
l'acide $L$-glutamigue, la $L$-alanine, la $L$-tyrosine et la $L$-lysine dans une fraction molaire moyenne de 0,141 , de 0,427 , de 0,095 et de 0,338 , resper

Le mode d'action de l'effet de l'acétate de glatiramère dans la sclérose en plaques (SEP) n'est pas encore completement élucidé. On croit cependant que l'acétate de glatiramere exercerait un effet modulateur sur par les résultats des essais menés pour explorer la pathogenése de I'encéphalomyélite allergique expérimentale (EAE), affection qui peut être déclenchée chez plusieurs espèces animales et qui est généralement acceptée comme modèle expérimental de la SEP.

Les ettudes expérimentales sur animaux et les systèmes in vitro laissent supposer que l'administration de l'acétate de glatiramère induit et active des lymphocytes $T$ suppresseurs spécifiques dans le

Comme le profit immunologique de l'acétate de glatiramère n'est pas encore complètement élucidé, il est possible que le produit puisse avoir des effets sur les réactions immunitaires naturelles (voir PRÉCAUTIONS). Pharmacocinétique : Les résultats obtenus au cours des essais pharmacocinétiques menés chez les humains (volontaires sains) et les animaux étayent l'hypothèse selon laquelle une fraction importante de la dose thérapeutique délivrée au patient par voie sous-cutanée est hydrolysée localement. Neanmoins, de grands fragments d'acétate de glatiramère peuvent être reconnus par les anticorps réactifs contre l'acétate de glatiramere. Une certaine proportion de la dose injectee, intacte ou partiellement hydrolysee, passerait régionaux; de plus, il est possible qu'une partie du produit intact passe dans la circulation genérale.

Essais cliniques : L'efficacité de COPAXONE" (acétate de glatiramere pour injection) a été évaluée dans le cadre de deux essais comparatifs (avec placebo) chez des patients atteints de SEP rémittente. Un troisième essai comparatif (avec placebo) a évalue les effets de l'acétate de glatiramère sur les paramètres IRM. Dans
ces essais, on a eu recours à une dose de $20 \mathrm{mg} / j$ jour. Aucune autre dose ou schéma posologique n'ont été étudiés dans des essais comparatifs (avec placebo) sur la SEP rémittente.

Le premier essai Essai I (Essai BR-1) était un essai pilote comparatif (avec placebo) à répartition aléatoire en paires appariées, à groupes parallèles et à double insu qui a été mené dans un seul centre ${ }^{13}$. Cinquante patients atteints de SEP rémittente ont reçu, au hasard, $20 \mathrm{mg} /$ jour d'acétate de glatiramère $(n=25)$ ou un placebo $(n=25)$ par voie sous-cutanée. Sélon le protocole, le paramètre primaire de l'essai consistait en la proportion de patients exempts de poussée pendant les deux ans de l'essai. Deux autres résultats pertinents ont également servi de paramètres dans le cadre de cet essai : la fréquence des poussées pendant l'essai et la variation de la fréquence des poussées par comparaison à la fréquence des poussees pendant les deux
années précédant l'entrée à l'essai. Les résultats de cet essai (tableau 1) démontrent que l'acétate de annees precédant lentree à l'essai. Les résultats de cet essai (tableau 1) démontre

TABLEAU 1 - Essai BR-1 : résultats quant à Yefficacité

\begin{tabular}{|c|c|c|c|}
\hline \multirow{2}{*}{ Résultats } & \multicolumn{3}{|c|}{ Essair $r$} \\
\hline & $\begin{array}{l}\text { Acétate de glatiramère } \\
n=25\end{array}$ & $\begin{array}{c}\text { Placebo } \\
n=25\end{array}$ & Valeur de $p$ \\
\hline \% de patients exempts de pousséé & $14 / 25(56 \%)$ & $7 / 25(28 \%)$ & 0,085 \\
\hline Fréquence moyenne des poussées & $0,6 / 2$ ans & $2,4 / 2$ ans & 0,005 \\
\hline $\begin{array}{l}\text { Réduction de la fréquence des poussées } \\
\text { comparativement aux donnees avant lessai }\end{array}$ & 3,2 & 1,6 & 0,025 \\
\hline Délai médian avant la première poussée (jours) & $>700$ & 150 & 0,03 \\
\hline$\%$ de patients exempts de progression" & $20 / 25(80 \%)$ & $13 / 25(52 \%)$ & 0,07 \\
\hline
\end{tabular}

Le paramètre primaire de l'efficacité de l'Essai I consistait en la proportion de patients exempts de poussée pendant les deux ans de l'essai (\% de patients exempts de poussée). Les analyses portaient sur l'ensemble des sujets retenus au début de l'essai.

La progression se définissait comme une augmentation d'au moins un point de la cote DSS

'Essai II (01-9001) était un essai comparatif (avec placebo), multicentrique, à double insu et à répartition aléatoire. Deux cent cinquante et un patients atteints de SEP rémittente ont reçu, au hasard, $20 \mathrm{mg} /$ jour d'acétate de glatiramère $(n=125)$ ou un placebo $(n=126)$ par voie sous-cutanée. Les patients avaient fait l'objet d'un diagnostic de SEP rémittente selon les criteres standards et avaient subi au moins deux poussées pendant les deux années précédant immédiatement l'entrée à l'essai. Les patients devaient

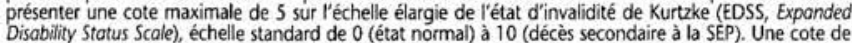
$\checkmark$ définit un patient ambulatoire qui a des difficultés à vaquer à toutes ses activités habituelles en raison d'une invalidité ; une cote de 6 définit un patient ambulatoire qui a besoin d'aide pour vaquer à ses occupations, tandis qu'une cote de 7 signifie que le sujet est confiné à un fauteuil roulant.

Les patients ont été examinés tous les trois mois pendant deux ans ainsi que dans les quelques jours suivant une poussée possible. Toute poussée devait être confirmée par un neurologue qui ignorait le traitement reçu et qui devait noter la présence de signes neurolog

(p. ex, la persistance de la lésion pendant au moins 48 heures).
Le protocole précisait que le paramètre primaire de l'essai était le nombre moyen de poussées pendant Le tableau 2 présente les résultats de l'analyse du paramètre primaire et de plusieurs paramètres secondaires de lEssai a deux ans, analyse portant sur lensemble des sujets retenus au début de lessai.
TABLEAU 2 - Essai de base (24 mois) à double insu: effet sur la fréquence des poussées

\begin{tabular}{|l|c|c|c|}
\hline \multicolumn{1}{|c|}{ Résultats } & \multicolumn{3}{|c|}{ Essai II $^{*}$} \\
\hline & $\begin{array}{c}\text { Acétate de glatiramère } \\
\mathbf{n = 1 2 5}\end{array}$ & $\begin{array}{c}\text { Placebo } \\
\mathbf{n = 1 2 6}\end{array}$ & Valeur de $\mathbf{p}$ \\
\hline Nombre moyen de poussées (2 ans) & 1,19 & 1,68 & 0,055 \\
\hline$\%$ de patients exempts de poussée & $42 / 125(34 \%)$ & $34 / 126(27 \%)$ & 0,25 \\
\hline Délai médian avant la première poussée (jours) & 287 & 198 & 0,23 \\
\hline \% de patients exempts de progression & $98 / 125(78 \%)$ & $95 / 126(75 \%)$ & 0,48 \\
\hline Variation moyenne de la cote EDSS & $-0,05$ & $+0,21$ & 0,023 \\
\hline
\end{tabular}

Le paramètre primaire de l'efficacité de l'Essai II était le nombre de poussées pendant le traitement. Les analyses portaient sur l'ensemble des sujets retenus au début de l'essai.

Moyenne ajustée de départ

persistant pendant au moins trois mois cone augmécutifs

Les effets de l'acétate de glatiramère sur la gravité des poussées n'ont pas été évalués dans ces deux essais. Les deux essais ont révélé que l'acétate de giatiramère avait un effet bénéfique sur la fréquence des poussées ; on considère donc que l'acétate de glatiramère est un produit efficace à cet égard.

Le troisième essai (9003) était un essai muiticentrique, multinational, avec surveillance IRM. Au total, 239 patients atteints de SEP rémittente (119 traités par l'acétate de glatiramère et 120 par un placebo) ont été répartis au hasard. Les critères d'inclusion étaient similaires à ceux de l'Essai II (Essai 01-9001) avec en plus le
critere selon lequel les patients devaient présenter au moins une lésion rehaussée par le Gd à l'examen IRM de sélection. Les patients ont été d'abord traités à double insu pendant neuf mois, au cours desquels ils ont subi des examens IRM mensuels. Le paramètre primaire de la phase à double insu était le nombre cumulatil total de lésions rehaussées par le Gd en pondération T1 pendant les neuf mois. D'autres paramètres IRM ont été évalués à titre de paramètres secondaires. Le tableau 3 résume les résultats obtenus pour les paramètres surveillés pendant la phase à double insu de neuf mois pour l'ensemble des sujets retenus au début de
l'essai. Compte tenu que le lien entre les résultats IRM et l'état clinique du patient fait l'objet d'une discussion, on ignore la valeur pronostique des résultats statistiquement significatifs suivants.

\begin{tabular}{|c|c|c|c|c|}
\hline $\mathbf{N}$ & Rèsultats & $\begin{array}{c}\text { Acétate de } \\
\text { glatiramere } n=113\end{array}$ & $\begin{array}{c}\text { Placebo } \\
\mathrm{n}=115\end{array}$ & $\begin{array}{c}\text { Valeur } \\
\text { de } p\end{array}$ \\
\hline \multicolumn{5}{|c|}{ Paramètre primalre } \\
\hline 1. & $\begin{array}{l}\text { Médianes du nombre cumulatif de lésions } \\
\text { rehaussées par le Gd en TI }\end{array}$ & 12 & 17 & 0,0037 \\
\hline \multicolumn{5}{|c|}{ Paramètres secondaires } \\
\hline 2. & $\begin{array}{l}\text { Médianes du nombre cumulatif de nouvelles } \\
\text { lésions rehaussées par le Cd en TI }\end{array}$ & 9 & 14 & 0,0347 \\
\hline 3. & Médanes du nombre cumulatif de nouvelles lésions en T2 & 5 & 8 & 0,01 \\
\hline 4. & $\begin{array}{l}\text { Médianes de la variation cumulative par rapport aux valeurs de } \\
\text { départ du volume (mL) des lésions rehaussées par le } \mathrm{Cd} \text { en TI }\end{array}$ & $-0,309$ & 0 & 0,0248 \\
\hline 5. & $\begin{array}{l}\text { Médianes de la variation cumulative par rapport aux } \\
\text { valeurs de départ du volume (mL) des lésions en } \mathrm{T} 2\end{array}$ & 8,852 & 13,566 & 0,0229 \\
\hline 6. & $\begin{array}{l}\text { Médianes de la variation cumulative par rapport aux valeurs } \\
\text { de départ du volume (mL) des lésions hypo-intenses en TI }\end{array}$ & 1,642 & 1,829 & 0,7311 \\
\hline 7. & Proportion de patients exempts de lésion rehaussée par le Gd en TI & $46,4 \%$ & $32,2 \%$ & 0,0653 \\
\hline
\end{tabular}

Le nombre moyen de poussées au cours de cet essai de neuf mois était de 0,50 pour le groupe COPAXONE
et de 0,77 pour le groupe placebo $(p=0,0077)$. Ur le groupe placebo $(\rho=0,0077)$.

INDICATIONS ET UTILISATION CLINIQUE Pour utilisation chez les patients ambulatoires atteints de sclérose en plaques remittente en vue de réduire la frequence des poussées.

L'tinnocévitéé évalues.

CONTRE-INDICATIONS COPAXONE" (acétate de glatiramère pour injection) est contre-indiqué chez les patients présentant une hypersensibilité avérée à l'acétate de glatiramère ou au mannitol.

MISES EN GARDE La seule voie d'administration recommandée de COPAXONE' (acétate de glatiramère pour injection) est la voie sous-cutanée. COPAXONE ne doit pas être administré par voie intraveineuse. Symptómes qui risquent d'avoir une origine cardiaque : Environ $26 \%$ des patients qui ont reçu COPAXONE dans lessai placebo) ont subi au moins un épisode de ce qui a été décrit comme une douleur thoracique transitoire (voir EFFETS INDESIRABLES : Douleur thoracique). Seulement certains de ces épisodes sont survenus dans le cadre de la réaction apparaissant immédiatement aprés l'injection (voir EFFETS INDESIRABLES: Réaction suivant linjection), Aucune surveillance de l'ECC n'a été réalisée pendant l'un de ces épisodes, et la pathogenèse de ce symptöme demeure inconnue. Comme les patients des essais comparatifs ne presentaient pas de troubles
cardiovasculaires significatifs (classe I ou II selon la New York Heart Association), on ignore les risques que courent les patients qui souffrent d'une atteinte cardiovasculaire et qui reçoivent COPAXONE' dans le trattement de la sclérose en plaques.

L'administration de COPAXONE" a été associée à une réaction suivant línjection consistant en un ensemble de symptómes qui surviennent immédiatement après l'injection et qui peuvent comprendre les bouffees congestives, la douleur thoracique, les palpitations, Panxiéte,
(voir EFFETS INDESIRABLES : Réaction suivant l'injection).

COPAXONE ${ }^{\circ}$ 'a pas été étudié chez des sujets présentant des antécédents de réactions anaphylactoides graves, de bronchopneumopathie chronique obstructive ou d'asthme ni chez des patients qui reçoivent des
médicaments dans le traitement de l'une de ces deux dernières affections. II convient donc de faire preuve de prudence pour ce qui est de l'utilisation de COPAXONE' chez ce type de patients.

De rares cas de réactions anaphylactoides $(<1 / 1000)$ ont été rapportés en association avec l'utilisation de COPAXONE" au cours de la période de postcommercialisation. Certains cas ont nécessité un traitement par iepinéphrine et autre traitement médical approprie.

PRECAUTIONS Générales : Les patients doivent connaitre les techniques de reconstitution et d'auto-iniection respectant l'asepsie de sorte que COPAXONE' (acétate de glatiramère pour injection) soit administré de façon sưre (voir INFORMATION A L'INTENTION DU PATIENT). La première injection doit être effectuée sous la supervision d'un professionnel de la santé qualifié. ll convient de vérifier périodiquement si les patients comprennent et respectent les techniques d'auto-administration respectant l'asepsie. On doit avertir les patients de ne pas reutiliser les aiguilles et les seringues et leur expliquer les procédures de mise au rebut appropriées. Les patients doivent jeter les aiguilles et les seringues utilisées dans un contenant non perforable. On

Considérations en matière d'utilisation d'un produit capable de modifier les réactions immunitaires: COPAXONE étant une substance antigénique, son utilisation risque de déterminer des réactions délétères pour I'hôte. On ignore en outre si COPAXONE' peut modifier les réactions immunitaires normales de l'être humain, comme la reconnaissance des antigènes étrangers. II est donc possible que le traitement par COPAXONE' puisse altérer les mécanismes de défense de l'organisme contre les infections ainsi que les mécanismes de surveillance des tumeurs. Aucune évaluation systématique de ces risques n'a encore été entreprise. L'altération continue de l'immunité cellulai

Des anticorps réactifs contre l'acétate de glatiramère sont formés chez p ment quotidien avec la dose recommandée. Selon des essais menés chez le rat et le singe, des complexes immun se déposent dans les glomérules rénaux. De plus, dans un essai comparatif portant sut 125 patients atteints de
SEP remittente qui ont recu $20 \mathrm{mg}$ d'acétate de glatiramère pendant deux ans, les taux sériques d'lgC ont atteint SEP remittente qui ont reçu $20 \mathrm{mg}$ d'acétate de glatiramère pendant deux ans, les taux sériques d'l $\mathrm{gC}$ ont atteint
des taux au moins trois fois plus elevés que les taux de départ chez $80 \%$ des patients trois mois après le début des taux au moins trois fois plus élevés que les taux de départ chez $80 \%$ des patients trois mois après le début
du traitement. Après 12 mois de traitement, cependant, $30 \%$ des patients avaient toujours des taux d'laC au du traitement. Après 12 mois de traitement, cependant, $30 \%$ des patients avaient toujours des taux d'lgC au
moins trois fois plus élevés que les taux de départ et $90 \%$ avaient des taux plus élevés que les taux de départ après 12 mois, Les anticorps sont uniquement de sous-type lgC, et surtout de sous-type lgG-1. Aucun anticorps de type lgE n'a été détecté chez aucun des 94 sérums testes. Néanmoins, compte tenu que l'anaphylaxie peut être Des a administration de presque toutes les substances etrangères, ce risque ne peut etre exclu.

Des essais précliniques visant à évaluer le potentiel carcinogène de l'acétate de glatiramère chez la souris et le rat n'ont fait ressortir aucun signe de potentiel carcinogène associé a l'administration sous-cutanée de l'acétate de glatiramère à des doses allant jusqu'à $30 \mathrm{mg} / \mathrm{kg} /$ jour chez le rat et jusqu'à $60 \mathrm{mg} / \mathrm{kg} /$ jour chez la souris (voir TOXICOLOCIE : Potentiel carcinogène). On ignore si ces résultats sont extrapolables à l'humain (voir PREC
en matière d'utilisation d'un produit capable de modifier les réactions immunitaires).

en matière d'utilisation d'un produit capable de modifier les réactions immunitaires).
Interactions médicamenteuses : Les interactions médicamenteuses entre COPAXONE" et d'autres produits Interactions médicamenteuses : Les interactions médicamenteuses entre COPAXONE" et d'autres produits
n'ont pas fait Yobjet d'une évaluation complète. Les résultats des essais cliniques à ce jour ne font pas ressortir n'ont pas fait Yobjet d'une évaluation complète. Les résultats des essais cliniques à ce jour ne font pas ressortir
d'interaction significative entre COPAXONE d'interaction significative entre COPAXONE' et les traitements habituels de la SEP, y compris I administration
concomitante de corticostéroides pendant un maximum de 28 jours. COPAXONE' n'a pas été évalué de façon formelle en association à l'interféron bêta. En revanche, 246 patients chez lesquels le traitement par l'interféron béta a échoué ou qui n'ont pas toléré le traitement et qui ont été par la suite traités avec COPAXONE dans
cadre d'un essai clinique ouvert n'ont pas signalé l'apparition d'effets indésirables graves ou inattendus pouvant être liés au traitement.

Grossesse : Aucun essai comparatif rigoureux portant sur des femmes enceintes n'a été réalisé. Les essais précliniques n' ont pas fart ressortir de signe de texicite liee a la reproduction (voir TOXICOLOCIE : Reproduction et tératologie). Etant donne que les essais de reproduction chez les animaux ne permettent pas toujours de
prévoir les effets d'un produit chez l'être humain ce médicament ne doit être administré pendant la grossesse que si son utilité a été clairement établie. Dans le cadre des essais cliniques de précommercialisation portant sur COPAXONE:, sept femmes sont devenues enceintes pendant le traitement par le produit actif. L'une de ces femmes a été perdue de vue pendant le suivi ; trois femmes ont choisi d'interrompre leur grossesse, et les trois autres ont cessé de prendre le produit un mois, un mois et demi et deux mois après avoir découvert qu'elles étraient enceintes. Ces trois femmes ont donné naissance à des enfants en bonne santé.

Allaitement : On ignore si le produit passe dans le lait maternel. Étant donné qưun grand nombre de médicaments passent effectivement dans le lait maternel, l'administration de COPAXONE" à une femme qui allaite ne doit etre envisagée qu'après une évaluation soigneuse du rapport risques-avantages, et le produit doit etre utilisé avec prudence.

Enfants : L'innocuité et l'efficacité de COPAXONE' n'ont pas été établies chez les sujets de moins de 18 ans. Patients âgés : COPAXONE' n'a fait l'objet d'aucune évaluation spécifique chez les personnes ágées (plus de 65 ans).

Insuffisants rénaux : Les paramètres pharmacocinétiques de COPAXONE' n'ont pas été déterminés chez les sujets souffrant d'un dysfonctionnement rénal.

EFFETS INDÉSIRABLES Au cours des essais cliniques de précommercialisation, environ 900 personnes ont reçu au moins une dose de COPAXONE' (acétate de glatiramère pour injection) dans le cadre d'essais cliniques comparatifs ou non. L'exposition totale des patients à COPAXONE au cours d'essais cliniques s'échelonne de six mois (693
patients) à deux ans ( 306 patients), et à plus de sept ans ( 69 patients) à raison d'une dose quotidenne de $20 \mathrm{mg}$. Au cours des essais comparatifs, les effets indésirables le plus fréquemment associés à l'utilisation de COPAXONE* et dont l'incidence était supérieure à celle qui a été observée chez les sujets qui recevaient le placebo étaient les
suivants : réactions au point d'injection, vasodilatation, douleur thoracique, asthénie, infection, douleur, nausées, 
arthralgie, anxiété et hypertonie.

Sur un total de 844 patients qui pouvaient taire l'objet d'une évaluation de l'innocuité du produit, environ $8 \%$ des sujets ont abandonne le traitement en raison d'effets indésirables. Les effets indésirables le plus fréquemment associés a labandon du traitement étaient les suivants : réactions au point d'injection $(6,5 \%)$, vasodilatation, grossesse indésirables graves ayant entraîné l'abandon du traitement et que les chercheurs considéraient comme liés l'administration de COPAXONE⿱一𫝀, on compte un cas de maladie du sérum ayant menacé la survie du patient. Réaction sulvant I'Injection : Environ $10 \%$ des patients atteints de sclérose en plaques qui ont reçu
COPAXONE immédiatement après l'injection sous-cutanée de COPAXONE*. Les symptômes ressentis pouvaient comprendre les bouffées congestives, la douleur thoracique, les palpitations, l'anxiété, la dyspnée, la constriction de la gorge et rurticaire. Ces symptômes étaient toujours transitoires et spontanément résolutif́s et n'exigeaient pas de traitement
particulier. lls survenaient en général plusieurs mois après l'etablissement du traitement et parfois plus tôt. Un patient particulier. lls survenaient en general plusieurs mois après letablissement du traitement et parfois plus tot. Un patient sic ces épisodes sont liés à des mécanismes immunologiques ou non, ni si plusieurs épisodes semblables survenant che un même patient relèvent de mécanismes identiques. En fait, on ignore si cet ensemble de symptômes représente véritablement un syndrome spécifique. Au cours de la période de postcommercialisation, des patients ont signalé avoir vertabi des symptomes syimilaires et recus des soins médicaux du'urgence (voir MISES EN CARDE).

subi des symptomes similaires et reçu des soins medicaux d'urgence (voir MIS multicentrique de précommercialisation (par comparaison à $10 \%$ des patients ayant reçu un placebo) ont subi au moins un épisode de ce qui a été décrit comme une douleur thoracique transitoire, Seulement certains de ces épisodes sont survenus dans le cadre de la réaction apparaissant immédiatement après l'iniection déerite dans le paragraphe précédent. Le lien temporel entre la douleur thoracique et l'injection d'acétate de glatiramère n'était pas toujours connu. La douleur était trannsitoire (elle ne durait habituellement que quelques minutes), apparaissait souvent seule et ne semblait pas laisser d'importantes séquelles cliniques. Aucune surveillance de l'ECC n'á été réalisée pendant l'un de ces épisodes. Certains patients ont subi plus d'un épisode de douleur thoracique, et ces
épisodes commençaient à apparaitre, en régle générale, au moins un mois après l'établissement du traitement. La pathogenèse de ce symptóme demeure inconnue. ll y a eu un seul épisode de douleur thoracique au cours duquel un ECZ complet a été effectué; I'ECG $n^{\prime}$ a révélé aucun signe d'ischémie. Comme les patients des essais cliniques ne présentaient pas de troubles cardiovasculaires significatify (classe I ou ll selon la New York Heart Association), on ignore les risques que courent les patients qui souffrent d'une atteinte cardiovasculaire et qui reçoivent l'acétate de une origine cardiaque) Le tableau 4 dresse la liste des effets indésirables observés après un maximum de 35 mois de traitement (plus de 27 mois de l'Essai II (essai comparatif [avec placebol multicentrique de précommercialisation portant sur des patients atteints de sclérose en plaques remittente) et dont l'incidence etait d'au moins $2 \%$ parmi les sujets qui recevaient COPAXONE ${ }^{3}$ et
d'au moins $2 \%$ de plus que lincidence observée parmi les sujets du méme essai qui recevaient le placebo, peu importe
le lien de cause à effet entre la réaction et le traitement. Aucun résultat des épreuves de laboratoire répondant à ces le lien de cause à effet

critères n'a été signalé.

Il est à noter que les données du tableau 4 ne peuvent pas servir à prévoir l'incidence des effets indésirables du traitement dans le cadre de l'exercice normal de la médecine, étant donné que les caractéristiques des patients ainsi que d'autres facteurs risquent de ne pas être les mèmes que ceux des essais cliniques. Ces données foumissent tout de même et non liés au médicament en ce qui a trait à l'incidence des effets indésirables dans la population étudiéé

TABLEAU 4

Essal comparatif de précommerclallsatlon chez des patients atteints de SEP

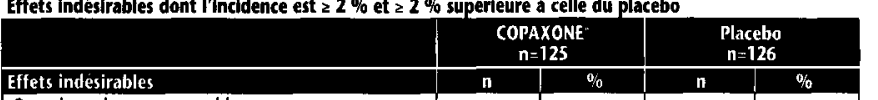

Organisme dans son ensemble

Douleur au point d'injection

Asthénie

Erythème au point d'injection

Prurit au point d'injection

Syndrome pseudo-grippal
Inflammation au point d'injection

Douleur dorsale

Douleur thoracique

Masse au point d'iniection

Induration au point d'injection

Papule au point d'injection

Douleur au cou

Urticaire au point d'injection

Hérnorragie au point d'injection

Frisson

Réaction au point d'injection

Atrophie au point d'injection

\begin{tabular}{|c|c|c|c|c|}
\hline $\begin{array}{l}\text { Appareil cardiovasculaire } \\
\text { Vasodilatation } \\
\text { Palpitations } \\
\text { Migraine } \\
\text { Syncope } \\
\end{array}$ & $\begin{array}{c}34 \\
14 \\
9 \\
8 \\
\end{array}$ & $\begin{array}{l}27,2 \\
11,2 \\
7,2 \\
6,4 \\
\end{array}$ & $\begin{array}{l}14 \\
6 \\
5 \\
4 \\
\end{array}$ & $\begin{array}{l}11,1 \\
4,8 \\
4,0 \\
3,2 \\
\end{array}$ \\
\hline $\begin{array}{l}\text { Appareil digestif } \\
\text { Nausées } \\
\text { Vomissements } \\
\text { Anorexie } \\
\text { Castro-entérite } \\
\text { Candidose orale } \\
\text { Carie dentaire }\end{array}$ & $\begin{array}{c}29 \\
13 \\
6 \\
6 \\
3 \\
3\end{array}$ & $\begin{array}{l}23,2 \\
10,4 \\
4,8 \\
4,8 \\
2,4 \\
2,4\end{array}$ & $\begin{array}{l}22 \\
7 \\
3 \\
2 \\
0 \\
0\end{array}$ & $\begin{array}{l}17,5 \\
5,6 \\
2,4 \\
1,6 \\
0 \\
0\end{array}$ \\
\hline $\begin{array}{l}\text { Systèmes hématopoiétique et lymphatique } \\
\text { Adénopathie } \\
\text { Ecchymose }\end{array}$ & $\begin{array}{l}23 \\
15\end{array}$ & $\begin{array}{l}18,4 \\
12,0\end{array}$ & $\begin{array}{l}12 \\
12\end{array}$ & $\begin{array}{l}9,5 \\
9,5\end{array}$ \\
\hline $\begin{array}{l}\text { Troubles métaboliques et nutritionnels } \\
\text { Édème périphériqué } \\
\text { Cain pondéral } \\
\text { Edème }\end{array}$ & $\begin{array}{c}14 \\
7 \\
5\end{array}$ & $\begin{array}{l}11,2 \\
5,6 \\
4,0\end{array}$ & $\begin{array}{l}7 \\
0 \\
1\end{array}$ & $\begin{array}{c}5,6 \\
0 \\
0,8\end{array}$ \\
\hline $\begin{array}{l}\text { Appareil musculosquelettique } \\
\text { Arthralgie }\end{array}$ & 31 & 24,8 & 22 & 17,5 \\
\hline $\begin{array}{l}\text { Systeme nerveux } \\
\text { Hypertonie } \\
\text { Tremblement } \\
\text { Agitation } \\
\text { Confusion } \\
\text { Nystagmus }\end{array}$ & $\begin{array}{l}44 \\
14 \\
7 \\
5 \\
5\end{array}$ & $\begin{array}{l}35,2 \\
11,2 \\
5,6 \\
4,0 \\
4,0\end{array}$ & $\begin{array}{l}37 \\
7 \\
4 \\
1 \\
2\end{array}$ & $\begin{array}{l}29,4 \\
5,6 \\
3,2 \\
0,8 \\
1,6\end{array}$ \\
\hline $\begin{array}{l}\text { Appareil respiratoire } \\
\text { Rhinite } \\
\text { Dyspnée } \\
\text { Bronchite }\end{array}$ & $\begin{array}{l}29 \\
23 \\
18\end{array}$ & $\begin{array}{l}23,2 \\
18,4 \\
14,4\end{array}$ & $\begin{array}{c}26 \\
8 \\
12\end{array}$ & $\begin{array}{l}20,6 \\
6,4 \\
9,5\end{array}$ \\
\hline $\begin{array}{l}\text { Peau et annexes cutanées } \\
\text { Hypersudation } \\
\text { Érythème } \\
\text { Troubles dermatologiques } \\
\text { Nodule cutané } \\
\text { Verrue }\end{array}$ & $\begin{array}{l}15 \\
8 \\
5 \\
4 \\
3\end{array}$ & $\begin{array}{l}12,0 \\
6,4 \\
4,0 \\
3,2 \\
2,4\end{array}$ & $\begin{array}{l}10 \\
4 \\
2 \\
1 \\
0\end{array}$ & $\begin{array}{c}7,9 \\
3,2 \\
1,6 \\
0,8 \\
0\end{array}$ \\
\hline $\begin{array}{l}\text { Organes des sens } \\
\text { Douleur auriculaire } \\
\text { Troubles oculaires }\end{array}$ & $\begin{array}{c}15 \\
8\end{array}$ & $\begin{array}{l}12,0 \\
6,4\end{array}$ & $\begin{array}{c}12 \\
1\end{array}$ & $\begin{array}{l}9,5 \\
0,8\end{array}$ \\
\hline $\begin{array}{l}\text { Voies urogénitales } \\
\text { Miction impérieuse } \\
\text { Candidose vaginale } \\
\text { Dysménorrhée } \\
\text { Grossesse accidentelle } \\
\text { Impuissance }\end{array}$ & $\begin{array}{c}20 \\
16 \\
12 \\
4 \\
3\end{array}$ & $\begin{array}{l}16,0 \\
12,8 \\
9,6 \\
3,2 \\
2,4\end{array}$ & $\begin{array}{l}17 \\
9 \\
9 \\
0 \\
0\end{array}$ & $\begin{array}{c}13,5 \\
7,1 \\
7,1 \\
0 \\
0\end{array}$ \\
\hline
\end{tabular}

Voici les autres effets qui sont survenus chez au moins $2 \%$ des patients mais dont l'incidence dans le groupe placealées, ecchymose au point d'iniection, blessure accidentelle, douleur Organisme dans son ensemble : Cephalees,

Apporeil digestif : Dyspepsie constipation, dysphagie, incontinence fécale, flatulence, nausées et vomissements, gastrite, gingivite, abcès périodontique et sécheresse de la bouche.

appareil musculosquelettique : Myasthenie et myalgie.

système nerveux : Etourdissements, hypoesthésie, paresthésie, insomnie, dépression, dysesthésie, troubles de a coordination, somnolence, troubles de la démarche, amnésie, instabilité emotionnefle, signe de Lhermitte, anomalies de la pensee, secousses musculaires, euphorie et troubles du sommeil.

Apporeil respiratore: Pharyngite, sinusite, aggravation de la toux et iaryngite.

Organes des sens : Anomalies de la vision, diplopie, amblyopie, douleur oculaire, conjonctivite, acouphènes,

Voies urogénitales : Infection des voies urinaires, augmentation de la fréquence des mictions, incontinence urinaire, rétention urinaire, dysurie, cystite, métrorragie, doukeur mammaire et vaginite.

Les données portant sur les effets indessirables qui sont apparus au cours d'essais cliniques comparatifs ont été analysées dans l'optique d'évaluer les différences entre les sexes. Or, aucune différence cliniquement significaive n'a été relevée. Dans ces essais cliniques, $92 \%$ des patients étaient de race blanche, ce qui est représentatif de la population de patients atteints de sclérose en plaques. De plus, la vaste majorité des patients traités par
COPAXONE étaient ágés de 18 à 45 ans. Par conséquent, on disposait de trop peu de données pour effectuer COPAXONE ${ }^{\star}$ étaient ágés de 18 à 45 ans. Par conséquent, on disposait de trop peu de données pour effect

une analyse de l'incidence des effets indésirables en fonction de groupes d'âge cliniquement pertinents. variations des paramètres de laboratoire (hématologie, biochimie sanguine et analyse des urines) qui étaient significatives sur le plan clinique étaient comparables entre les patients du groupe COPAXONE" et ceux du groupe placebo, dans le cadre des essais cliniques à l'insu. Aucun patient ayant reçu COPAXONE" ne s'est retiré d'un essai en raison d'une anomalie des résultats des épreuves de laboratoire.

\section{utres effets indésirables observés durant tous les essols cliniques}

COPAXONE ${ }^{\oplus}$ a été administré à environ 900 personnes dans l'ensemble des essais cliniques, dont seulement certains étaient comparatifs (avec placebo). Au cours de ces essais, tous les effets indésirables ont été enregistrés par les chercheurs cliniques à l'aide de leur propre terminologie. De façon à donner une estimation efficace de la proportion des patients qui ont subi des effets indésirables, les effets semblables ont été regroupés en un plus petit nombre de categories normalisées faisant appel à la terminologie du dictionnaire COSTART II. Tous les effe signales qui sont survenus a au moins deux reprises ainsi que les effets potentiellement graves qui sont survenus une seule fois sont inclus dans celte compilation, a l'exception des effets deja inscrits au tableau precédent, les qui se sont manifestés chez au moins $2 \%$ des patients traités et qui étaient présents à une fréquence égale ou plus grande que dans le groupe placebo.

Les effets indésirables ont éte de plus classés en fonction des systèmes ou des appareils et énumérés en ordre décroissant de fréquence selon les définitions suivantes: les effets indésirables fréquents sont ceux qui sont

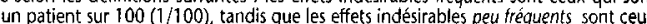
gui sont survenus dans une proportion de un patient sur 100 (1/700) à un patient sur $7000(1 / 1000$ ). Organisme dans son ensemble : Fréquents : CEdème au point d'injection, atrophie au point d'injection, abcès et hypersensibilité au point d'injection.

Peu fréquents : Hématome au point $d^{\prime}$ 'injection, fibrose au point d'injection, faciès lunaire, cellulite, cedèm généralisé, hernie, abcès au point d'injection, maladie du sérum, tentative de suicide, hypertrophie au point ainjection, melanose au point dimjection, lipome et reaction de photosensibilite.

Appareil cardiovasculaire : Frequent : Hypertension. Peu trequents: Hypotension, claquement systolique, souffile systolique, fibrillation auriculaire, bradycardie, apparition d'un quatrième bruit du cœur, hypotension

orthostatique et varices.
Appareil digestif : Peu fréquents : Sécheresse de la bouche, stomatite, sensation de brùlure sur la langue, cholécystite, colite, ukère de l'œesophage, œesophagite, cancer gastro-intestinal, hémorragie gingivale, hépatomégalie, augmentation de l'appétit, méléna, ulcération de la bouche, troubles

hemorragie rectale, tenesme, coloration anormale de la langue et ukere duodena

Troubles gastro-intestinaux : Fréquents : Défécation impérieuse, candidose orale, hypertrophie des glandes salivaires, carie dentaire et stomatite ulcéreuse.

Systèmes hématopoiétique et lymphatique : Peu fréquents : Leucopénie, anémie, cyanose, éosinophitie,

hématémèse, lymphoedème, pancytopénie et : Pén fréquents : Leucopenie, anémie, cyanose, éosinophilie Troubles métaboliques et nutritionnels : Peu fréquents : Perte pondèrale, intolérance à l'akcool, syndrome de Cushing, goutte, anomalies de la cicatrisation et xanthome. Appareil musculosquelettique : Peu fréquents : Arthrite, atrophie musculaire, douleur osseuse, bursite, douleur rénale, troubles musculaires, myopathie, ostéomyélite, douleur tendineuse et ténosynovite.

Système nerveux : Fréquents: Rêves inhabituels, instabilité émotionnelle et stupeur. Peu frequents: Aphasie, ataxie, convulsion, paresthésie péribuccale, dépersonnalisation, hallucinations, hostilité, hypocinésie, coma, troubles de la concentration, paralysie faciale, diminution de la libido, réaction maniaque, troubles de la mémoire, myoclonie, révralgie, réaction paranoide, paraplégie, dépression psychotique et stúpeur transitoire. Appareil respiratoire : Fréquent : Hyperventilation, thume des foins. Peu fréquents: Asthme, pneumonie, épistaxis, hypoventilation et modification de la voix.

Peau et annexes cutanées : Fréquents : Eczéma, zona, éruption pustuleuse, atrophie cutanée et verrues. Peu fréquents: Sécheresse cutanée, hypertrophie cutanée, dermatite, furonculose, psoriasis, angio-cedème, tumeur cutanée bénigne, cancer de la peau, vergetures et eruption vésiculabulleuse.

Organes des sens : Fréquents : Atteinte du champ visuel. Peu fréquents : Sécheresse oculaire, otite externe, ptose, cataractes, ulcère de la cornée, mydriase, névrite optique, photophobie et agueusie.

Voies urogénitales : Fréquents: Aménorrhée, hématurie, impuissance, ménorragie, anomalies des résultats du test de Papanicolaou, pollakiurie et hémorragie vaginale. Peu fréquents: Vaginite, douleur au flanc (rein), avortement, engorgement mammaire, hypertrophie mammaire, douleur mammaire, cancer in situ du col de 'utérus, mastose sclérokystique, calcul renal, nycturie, kyste ovarien, priapisme, pyélonephrite, anomalies de Effets ind sexuelle et uetrite.

\section{des essais cliniques}

'experience de postcommercialisation a dégagé un profil d'effets indesirabies similaire à celui présenté $c$ dessus. Après la mise sur le marché, on a signalé des effets indésirables, autres que celles indiquees Ci-dessus, qui sont survenues pendant le traitement par COPAXONE (acetate de glatiramere pour injection). Ces réaclons, qui peuvent avoir ou non un lien de causalité avec le médicament, comprennent : Organisme dans son ensemble : Septicémie, syndrome lupoide, hydrocéphalie, distension de l'abdomen,
hypersensibilité au point d'injection, réaction allergique, réaction anaphylactoide, infection bactérienne,

Appareil cardiovasculaire : Thrombose, maladie vasculaire périphérique, épanchement péricardique, infarcus du myocarde, thrombophlébite extensive, occlusion coronarienne, insuffisance cardiaque congestive, cardomyopathie, cardiomégalie, arrythmie, angine de poitrine et tachycardie

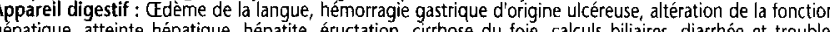
calculs biliaires, diarrhée et troubles

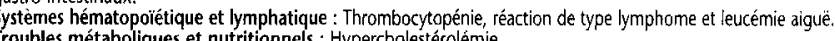
Appareil musculques

Système nerveux : Myélite, méningite, néoplasme du SNC, accident vasculaire cérébral, œedème cérébral, rèves Système nerveux : Myelite, meningite, , léoplasme du SNC, accident vasculaire cérébral, cedème cérébral, réves
inhabituels, aphasie, convulsion, névralgie, anxiété, pied tombant, nevvosité, trouble de l'élocution et vertige. Appareil respiratoire : Embolie pulmonaire, épanchement pleural, cancer du poumon, rhume des foins et laryngisme.

Peau et annexes cutanées : Herpès, prurit, éruption cutanée et urticaire.

Organes des sens : Glaucome, cécité et atteinte du champ visuel. insuffisance rénale, cancer du sein, cancer de la vessie et pollakiurie.

\section{SURDOSACE : SYMPTÓMES ET TRATEMENT}

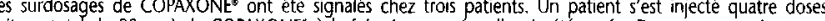
(soit un total de $80 \mathrm{mg}$ ) de COPAXONE' à la fois. Aucune sequelle n'a été notée. Deux autres patients, un homme de 28 ans et une femme de 37 ans, ont reçu, par erreur, trois injections de $20 \mathrm{mg}$ of COPAXONEe à des cardiaque ni de sa température. Le suivi téléphonique effectué plusieurs heures plus tard n'a pas révélé d'effets indésirables dans un cas comme dans l'autre.
POSOLOCIE ET MODE D'ADMINISTRATION

La prescription de COPAXONE doit être réservée aux médecins (ou après une consultation avec un médecin) qui connaissent a fond le aliagnostic et la prise en charge de la sclerose en plaques.

La dose recommandée de COPAXONE ${ }^{\sharp}$ (acétate de glatiramère pour injection ou acétate de glatiramère injectable) dans le traitement de la SEP rémittente est de une injection quotidienne de 20 mg par voie sous-cutanée.
Directives d'administration : Pour reconstituer le lyophilisat de COPAXONEs avant Y'injection, utiliser une 


\section{"Topamax}

topiramate

25,100 and $200 \mathrm{mg}$ Tablets and

15 and $25 \mathrm{mg}$ Sprinkle Capsules

Antiepileptic

\section{INDICATIONS AND CLINICAL US}

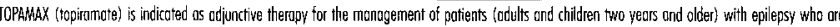

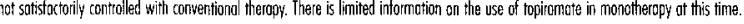
CQNTRAINDICATIONS

TOPAMAXX (tapiramnte) is controindicteded in jotients with o history of hypersensitivity to ony components of this product.

\section{WARNINGS}

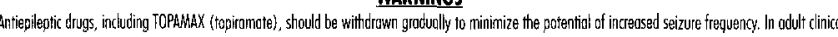
trials, dosages were decreased by $100 \mathrm{mg} /$ day of weekly intervals.

\section{Contral Nervous System Effects}

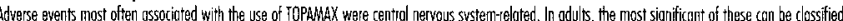
into two generd categories: i) psychomator slowing: difficuty with concentration and speech or onoutace problems, in particular, word-finding difficulties ond ii) sonmolence of fatigue

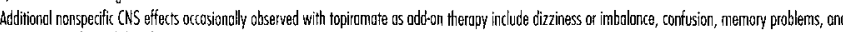
exccerbation of mood distubances (e.g. initability and depression).

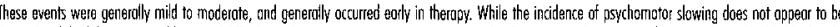

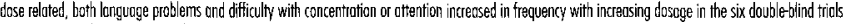
suggessing that these evennts cre dose reluted. (Ses ADVERSE REACTIONS

\section{PRECAUTIONS}

\section{Effects Reloted to Corbonic Anhydrose Inhibilion}

Kidney Stones A totcl of $32 / 1,715$ (1.5\%) of patients exposed to TOPAMAX itopiamate) duing its daveloprinent reported the occurence of kidney stones

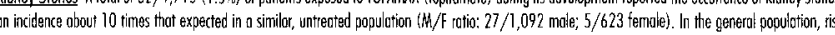
foctors for kidney stone formation include gender (mole), ages between $20-50$ years, prior stone formation, family history of nephrolithiosis, ond

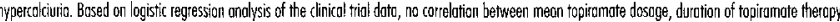
or age and the occurente of kidney stones wres established; of the risk factors evoluated, only gender (male) showed a correlotion with the occurrence of kidney stones. In the petliaticic actients studied, there were no kidnay stones observed.

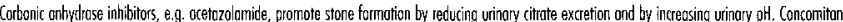

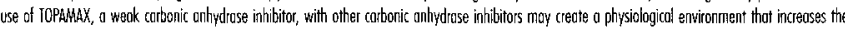
risk of kidhey stone formation, and should therefore be avoided.

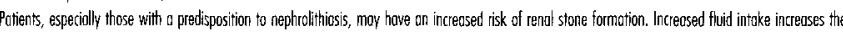

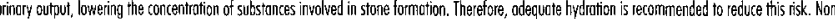
of the risk factors for nephrolitiosis can reliably sredict stone formation during TOPAMAX teeutrinent.

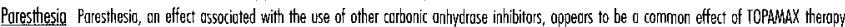
These events were usually intermittent and mild, and not necessarily relcted to the dosace of topiramate.

\section{Nutritional Supplementation}

A dietray supplement or increosed food intake may be considered if the patient is losing weight while on this metilication.

\section{Weight Loss in Pediatrics}

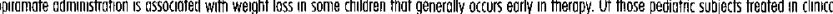
mials for of least o year who experienced weight loss, $96 \%$ showed o resumption of weight gain within the period tested. In 2.4 year oids, the mean change

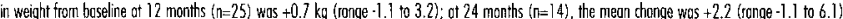

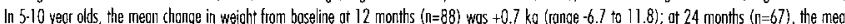

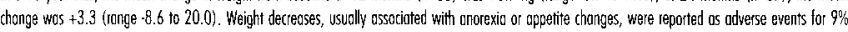
of topiramate-trected pediatric patients. The long term eflects of reduced weight gain in pediatic potients is not known.

\section{Adjustment of Dose in Renel Foilure}

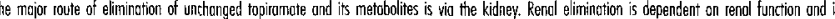

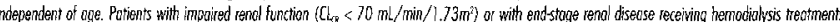

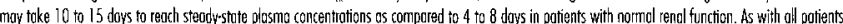
the fitrotion schedule should be cyided by clincol outcome (i.e. seizure control, avoidance of side effects) witt the knowildge that patients with krown rend impoirment moy require a longer time to recch steady-stote ot each dose. (See DOSAGE AND ADMINISTRATION.)

Decreased Hepatic Function

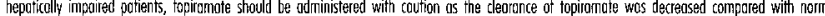
subiects.

\section{Information for Patients}

Adequote Hydrotion Podients, especiolly those with predisposing factors, should be instructed to maintoin on odequete fludid intoke in order to minimize the ist of lend stone formotion.

Effects on Ability 10 Drive and Use Mochines

Patientrs should be womed about the potential tor som:nolence, dizziness, confusion, ond difficulty concentrat ng and advised not to drive or operate machinery until they hove grined sufficient experience on topiromote to gouge whether it odversely offects their mentiol and/or motor performance.

\section{Drug Interactions}

Antiepileptic Drugs

Effects of TOPAMAX on Other Antiepileptic Drugs Potentiol interactions between topiramote ond standard AEDs were measured in controlled diniced

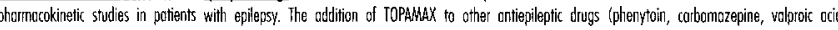

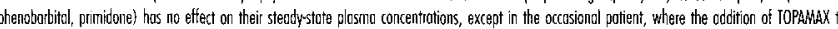
phenytloin may result in on increacse of plosma concentrutions of pherrytoin.

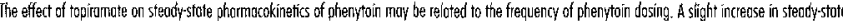

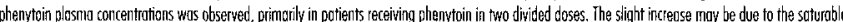

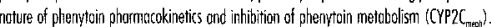

The oddition of IOPAthAX theraoy to phengytoin should be guided by dinical outcome. In generai, os evidenced in clinical trials, patients do nat require dos aciustrients. However, any patient on phemytoin showing dinicol signs or symotoms of toxicity shoudd hove phenytoin levels monitored.

Effects of Other Antieguilentic Drugs on TOPAMAX Phenytoin ond cabomazepine decraose the plasma concentrolion of TOPAHAX. The oddition of wittdrawal of phenytoin and/or carbamuzepine during adunctive theropy with TOPAMAX may require odjustnient of the dose of TOPAMAX. This should ba

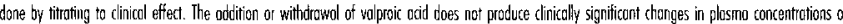
TOPAMAX, and therefore, does not wourunt dosage adiustrment of TOPMMX

The effect of these interactions on plesma concentrations ore summaized in Table

Table 1

Drug Interoctions with TOPAMAX Therooy

\begin{tabular}{|c|c|c|}
\hline $\begin{array}{l}\text { AED } \\
\text { Condmiristered }\end{array}$ & $\begin{array}{c}\text { AED } \\
\text { Concentrotion }\end{array}$ & $\begin{array}{c}\text { IOPAALAX } \\
\text { Concentrotion }\end{array}$ \\
\hline Phentoin & $\leftrightarrow^{\star \star}$ & $\downarrow 59 \%$ \\
\hline Carbomazepine (CBZ) & $\leftrightarrow$ & $\downarrow_{40 \%}$ \\
\hline CBZ epoxidex & $\leftrightarrow$ & NS \\
\hline Yalproic acid & $\downarrow 11 \%$ & $\downarrow 14 \%$ \\
\hline Phenobanbititl & $\leftrightarrow$ & NS \\
\hline Primidone & $\leftrightarrow$ & NS \\
\hline
\end{tabular}

is not odministered but is en active metobolite of carbomozepine

$\leftrightarrow \quad$ No effect on plosma concentration \& $15 \%$ change

** Plasmo concentrations increased $25 \%$ in some patients, generally those on o bi.t.d. dosing regimen of phenytoin

Plasma concentratiors decrease in individual patients

NS Not studied

AED Antiepileptic drus
Qther Drug Interactions

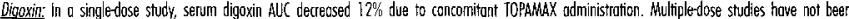
performed. When TOPAMAX is added or withdrown in patients on digoxin thercopy, coreful oftention should be given to the routine monitoring of servin digoxin

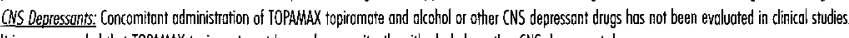
It is recormmented thet TOPAMAX topiramote not be used concomitantly with okohol or other CNS depressant drugs.

Oral Controceptives: In a pharmocokinetic interoction study with ord controceptives using a combination product containing rorethindrone plus ethiny

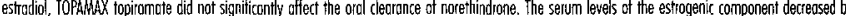

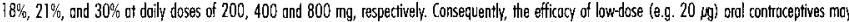
be reduced in this situation. Patients taking ord controceptives should receive o preparation conteining not less then $50 \mathrm{~kg}$ of estroger. Potients toking ord contracestives should be asked to ceport ony thenge in their bieeding potterns.

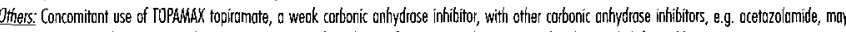
cracte o physiological enviromment that increasses the risk of renal stone formation, and should therefore be ovoided if poss ble.

\section{Laboratory Tests}

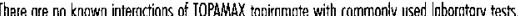

Use in Pregnancy and Lactation

Like other antiepileptic drugs, topiromote wos teratogenic in: mice, rots, ond rabbits. In rots, topiramote crosses the plocental borrier

There are no stucies using TOPAMAX topirannote in pregnnant women. However, TOPAMAX theropy should be used during pregnnency only if the potential benefit outweighs the potential isk to the fetus.

Topircmete is excreted in the milk of lactating rats. It is not known if topiromiate is excreted in human milk. Since manny drugs ate excreted in humnon milk

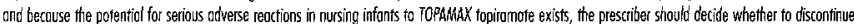
nusing or disconfinue the drug, toking into accourt the risk / benefit ratio of the importance of the diug to the mother ond the risks to the infant. In post-marketing experience, cases of hypospodias have been reported in mule infants exposed ir-utero to topiranote, with or without other onticonvulsants, however, a causal relationship with topiramote hos not been estabilished.

The effect of TOPAMAX topiromote on labour and delivery in humons is unknown.

Pediatric Use

Sofety and effectiveness in children under 2 yeors of age have not been estoblished.

Geriatric Use

There is linited infurrnation in patients over 65 years of age. The possibility of oge-associated reral function abnormabities should be considered when usiag TOPANAKX Dopisanonte.

\section{Race and Gender Effects}

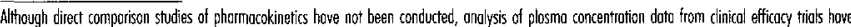
shown that race and gender appear to have rio effect on the plesmo clearcance of topiramole. In addition, based on pooled onalyses, toce and gender appen to hove no effect on the efficacy of topiramate.

Adult

\section{ADVERSE REACTIONS}

The most commonly observed adverse events associnted with the adiunctive use of TOPAMAX topirannte of dosages of 200 to $400 \mathrm{mg} /$ doy in controlied

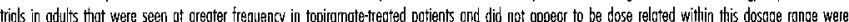

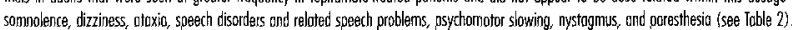

The most commilon dase-reloted adverse events ot cosages of 200 to $1,000 \mathrm{mg} /$ day were: nervousness, dffficulty with concentration or dttention, confusion, depression, anotexia, language problems, ond mood problems (see Toble 3).

Toble 2

ncidence of Treatment-Fmergent Adverse Events in Plocetbo-Oontrolled, Add-On Trials in ADLULS at

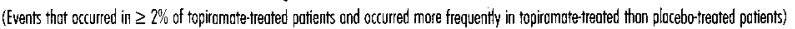

\begin{tabular}{llll}
\hline & \multicolumn{3}{c}{ TOPAMAX Dosage (mg/day) } \\
\cline { 2 - 4 } Body System/ & Placebo & $200-400$ & $600-1,000$ \\
Adverse Evert & $(\pi=216)$ & $(\pi=113)$ & $(\pi=414)$
\end{tabular}

\begin{tabular}{|c|c|c|c|}
\hline Adverse Event & $(\pi=216)$ & $(n=113)$ & $(\pi=414)$ \\
\hline \multicolumn{4}{|l|}{ Body as a Whole } \\
\hline Astheriu & 1.4 & 8.0 & 3.1 \\
\hline Back Pain & 4.2 & 6.2 & 2.9 \\
\hline Chest Poin & 2.8 & 4.4 & 2.4 \\
\hline Influenztrilike Symptoms & 3.2 & 3.5 & 3.6 \\
\hline Leg Poin & 2.3 & 3.5 & 3.6 \\
\hline Hot Flushes & 1.9 & 2.7 & 0.7 \\
\hline \multicolumn{4}{|l|}{ Nervous System } \\
\hline Dizziness & 15.3 & 28.3 & 32.1 \\
\hline Atoxia & 6.9 & 21.2 & 14.5 \\
\hline Speech Disordars/Reloted Speech Problems & 2.3 & 16.8 & 11.4 \\
\hline Nustagnius & 9.3 & 15.0 & 11.1 \\
\hline Paresthesia & 4.6 & 15.0 & 19.1 \\
\hline Tremor & 6.0 & 10.6 & 8.9 \\
\hline Longuage Problems & 0.5 & 6.2 & 10.4 \\
\hline Coordination Abrornul & 1.9 & 5.3 & 3.6 \\
\hline Hypoosesthesio & 0.9 & 2.7 & 1.2 \\
\hline Abnormal Gait & 1.4 & 1.8 & 2.2 \\
\hline \multicolumn{4}{|l|}{ Gustroinfestinal System } \\
\hline Nouseo & 7.4 & 13.5 & 12.1 \\
\hline Dyspepsia & 6.5 & 8.0 & 6.3 \\
\hline Abdominal Pouin & 3.7 & 5.3 & 7.0 \\
\hline Constipition & 2.3 & 5.3 & 3.4 \\
\hline Dry Mouth & 0.9 & 2.7 & 3.9 \\
\hline \multicolumn{4}{|l|}{ Metabolic and Nutritionol } \\
\hline Weight Decrease & 2.8 & 7.1 & 12.8 \\
\hline \multicolumn{4}{|l|}{ Neuropsychiotric } \\
\hline Somnolence & 9.7 & 30.1 & 27.8 \\
\hline Psychomotor Slowing & 2.3 & 16.8 & 20.8 \\
\hline Nervousness & 7.4 & 15.9 & 19.3 \\
\hline Oifficulty with Memory & 3.2 & 12.4 & 14.5 \\
\hline Confusion & 4.2 & 9.7 & 13.8 \\
\hline Depression & 5.6 & 8.0 & 13.0 \\
\hline Difficulty with Concentrotion/Attention & 1.4 & 8.0 & 14.5 \\
\hline Anorexio & 3.7 & 5.3 & 12.3 \\
\hline Agitution & 1.4 & 4.4 & 3.4 \\
\hline Mood Problems & 1.9 & 3.5 & 9.2 \\
\hline Aggressive Reaction & 0.5 & 2.7 & 2.9 \\
\hline Apthy & 0 & 1.8 & 3.1 \\
\hline Depersondization & 0.9 & 1.8 & 2.2 \\
\hline Emotional Lability & 0.9 & 1.8 & \\
\hline Reproductive, female & $(n=59)$ & $(n=24)$ & $(n=128)$ \\
\hline Breast Pain, Female & 1.7 & 8.3 & 0 \\
\hline 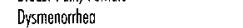 & 6.8 & 8.3 & 3.1 \\
\hline Menstrual Disorder & 0 & 4.2 & 0.8 \\
\hline Reproductive, Male & $\langle(\mathrm{n}=157)$ & $(\mathrm{n}=89)$ & $(n=286)$ \\
\hline Prostatic Disorder & 0.6 & 2.2 & 0 \\
\hline \multicolumn{4}{|l|}{ Respiratory System } \\
\hline Pharyngtis & 2.3 & 7.1 & 3.1 \\
\hline Rhinitis & 6.9 & 7.1 & 6.3 \\
\hline Sinusitits & 4.2 & 4.4 & 5.6 \\
\hline Dyspnea & 0.9 & 1.8 & 2.4 \\
\hline \multicolumn{4}{|l|}{ Skin and Appendages } \\
\hline \multirow{2}{*}{\multicolumn{4}{|c|}{$\begin{array}{l}\text { Minlious } \\
\text { Vision }\end{array}$}} \\
\hline & & & \\
\hline Diplopio & 5.6 & 14.2 & 10.4 \\
\hline Vision Abnomal & 2.8 & 14.2 & 10.1 \\
\hline \multicolumn{4}{|l|}{ White Cell and RES } \\
\hline Leukopenio & 0.5 & 2.7 & 1.2 \\
\hline
\end{tabular}

eukopenio

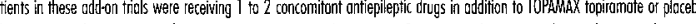

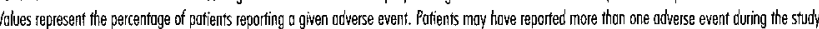
A -36 and can be indudad in more than one cidverse event cotegory. 
Table 3

Dose Related Adverse Events From Plocebo-Controlied, Add-On Triols in ADUUIS

\begin{tabular}{|c|c|c|c|c|}
\hline \multirow[b]{2}{*}{ Adverse Event } & \multirow[b]{2}{*}{$\begin{array}{l}\text { Placebo } \\
(n=216)\end{array}$} & \multirow[b]{2}{*}{$\begin{array}{c}200 \\
(n=45)\end{array}$} & \multicolumn{2}{|c|}{ TOPAMAX Dosage (mg/doy) } \\
\hline & & & $\begin{array}{c}400 \\
(n=68)\end{array}$ & $\begin{array}{c}600-1,000 \\
(n=414)\end{array}$ \\
\hline Fotigye & 13.4 & 11.1 & 11.8 & 29.7 \\
\hline $\begin{array}{l}\text { Nervousness } \\
\text { Difficulty with }\end{array}$ & 7.4 & 13.3 & 17.6 & 19.3 \\
\hline Concentrotion/Altention & 1.4 & 6.7 & 8.8 & 14.5 \\
\hline Confusion & 4.2 & 8.9 & 10.3 & 13.8 \\
\hline Depression & 5.6 & 8.9 & 7.4 & 13.0 \\
\hline Anorexio & 3.7 & 4.4 & 5.9 & 12.3 \\
\hline Longuoge problents & 0.5 & 2.2 & 8.8 & 10.1 \\
\hline Anxiety & 6.0 & 2.2 & 2.9 & 10.4 \\
\hline Mood probiens & 1.9 & 0.0 & 5.9 & 9.2 \\
\hline
\end{tabular}

In six double-blind clinical trials, 10.6\% of subjects (n=113) ossigned to a topiromote dosage of 200 to $400 \mathrm{mg} / \mathrm{cog}$ in oddition to their standard AED therapy discontinued due to adverse events, compared to $5.8 \%$ of subjects $(n=69)$ receiving plocebo. The percentage of subjects discontinuing due to odverse events oppeored to increase at dosages above $400 \mathrm{mg} / \mathrm{do}$. Overall, opproximotely $17 \%$ of all subjects $(n=527)$ who received topiramate in the double-blind trials dissontinued due to odverse events, compored to $4 \%$ of the subjects ( $\mathrm{n}=216$ ) receiving plocebo.

\section{Pediatrics}

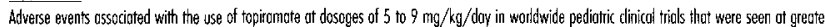
frequency in topiramote-treated patients were: fotigue, somnolence, anorexia, nervousness, difficulty with concentration/ottention, difficully with memory aggessive reaction, ond weight decrease.

Tobile 4 lists treatmentemergent odverse events thot occurred in of least $2 \%$ of chidren treated with 5 to $9 \mathrm{mg} / \mathrm{kg} /$ day topiramate in controlled trials that were numeticclly more common ttion in patients treated with placeho.

\section{Toble 4}

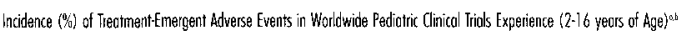
(Events that Occurred in $\geq 2 \%$ of Topiramote-Freated Pctients ond Occurrad More Frecuently in Topiramote Treated Than Placebo-reated Patients)

\begin{tabular}{|c|c|c|}
\hline $\begin{array}{l}\text { Body System/ } \\
\text { Adverse Eyent }\end{array}$ & $\begin{array}{l}\begin{array}{l}\text { Placebo } \\
(N=101)\end{array}\end{array}$ & $\begin{array}{l}\text { Topinomote } \\
(\mathrm{N}=98)\end{array}$ \\
\hline \multicolumn{3}{|l|}{ Body as a Whole - General Disorders } \\
\hline Fatigue & 5 & 16.3 \\
\hline Inivry & 12.9 & 14.3 \\
\hline Allergic Reaction & 1 & 2 \\
\hline \multicolumn{3}{|c|}{ Central \& Peripheral Hervous System Disorders } \\
\hline Goit Abnormol & 5 & 8.2 \\
\hline Ataxio & 2 & 6.1 \\
\hline Hyperkinesia & 4 & 5.1 \\
\hline Dizziness & 2 & 4.1 \\
\hline Speach Disorders/Reilated 5peech Probllems & 2 & 4.1 \\
\hline Conrulsions Aggrovated & 3 & 3.1 \\
\hline Hyporeflexia & 0 & 2 \\
\hline \multicolumn{3}{|l|}{ Gastrointestinal System Disorders } \\
\hline Nouseo & 5 & 6.1 \\
\hline Solviva Increosed & 4 & 6.1 \\
\hline Constipotion & 4 & 5.1 \\
\hline Gostiventeritis & 2 & 3.1 \\
\hline \multicolumn{3}{|l|}{ Metabolic and Nutritional Disorders } \\
\hline Weight Decreose & 1 & 9.2 \\
\hline Thirst & 1 & 2 \\
\hline \multicolumn{3}{|l|}{ Platelet, Bleeding \& Clorting Disorders } \\
\hline Pupura & 4 & 8.2 \\
\hline Epistraxis & 1 & 4.1 \\
\hline \multicolumn{3}{|l|}{ Nervous Disorders } \\
\hline Somnolence & 15.8 & 25.5 \\
\hline Anorexia & 14.9 & 24.5 \\
\hline Nervousness & 6.9 & 14.3 \\
\hline Personality Disorder (Bethryor Problems) & 8.9 & 11.2 \\
\hline Difficulty with Concentrotion/Attention & 2 & 10.2 \\
\hline Aggressive Reoction & 4 & 9.2 \\
\hline Insomnio & 6.9 & 8.2 \\
\hline Hood Problems & 6.9 & 7.1 \\
\hline Difficulty with Memory NOS: & 0 & 5.1 \\
\hline Emotiona: Lability & 5 & 5.1 \\
\hline Confusion & 3 & 4.1 \\
\hline Psychomotor Slowing & 2 & 3.1 \\
\hline \multicolumn{3}{|l|}{ Reproductive Disorders, Female } \\
\hline Leukorrheo & 0.0 & 2,3 \\
\hline \multicolumn{3}{|l|}{ Resistance Mechanism Disorders } \\
\hline Infection Viral & 3.0 & 7.1 \\
\hline Infection & 3.0 & 3.1 \\
\hline \multicolumn{3}{|l|}{ Respiratory System Disorders } \\
\hline Upper Respiriotory Fract Infection & 36.6 & 36.7 \\
\hline Preumenia & 1.0 & 5.1 \\
\hline \multicolumn{3}{|l|}{ Skin and Appendages Disorders } \\
\hline Skin Disorder & 2.0 & 3.1 \\
\hline Alopecil & 1.0 & 2.0 \\
\hline Dermatitis & 0.0 & 2.0 \\
\hline Hyportrichosis & 1.0 & 2.0 \\
\hline Rosh Erythennotous & 0.0 & 2.0 \\
\hline \multicolumn{3}{|l|}{ Urinory System Disorders } \\
\hline Urincry Incontinence & 2.0 & 4.1 \\
\hline \multicolumn{3}{|l|}{ Vision Disorders } \\
\hline Eye Abnornality & 1.0 & 2.0 \\
\hline Vision Abnommol & 1.0 & 2.0 \\
\hline \multicolumn{3}{|l|}{ White Cell and RES Disorders } \\
\hline Leukopenila & 0.0 & 2.0 \\
\hline
\end{tabular}

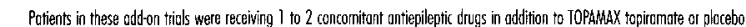

b Volves represent the percentuge of potients reporting o given adverse event. Patients moy hive reported more than one odverse event duing the study and can be included in more thon one odverse event category.

Not Otherwise Specfied

None of the pediatic patients who received topircmote adiunctive theropy at 5 to $9 \mathrm{mg} / \mathrm{kg} /$ day in controlled clinical trials discontinued due to odverse events. In open extensions of the controlied clinical triols, cporoximately $9 \%$ of the 303 pediatic patients who received topicomote of doscoes up to $30 \mathrm{mo} / \mathrm{kg} /$ day discontinued due to adverse events. Adverse events osscrioted with disconfriving theropy included oggrayated convulsions (2.3\%), langugoge problenris (1.3\%), ond difficuly with concentration/sttention (1.3\%)

in adult cond pediotic potients, nephrolitiosis was reported rarely. Isolated coses of thiomboembolic events hove also been reported; a cousd assocition with the diug has not been established.

When the salety experience of patients receiving TCPAMAX topiromate as adiunctive therooy in both double-blind and open-lobel tricls (1,446 odults ond 303 children) was anolyzed, o similar pottern of atyerse eyrects anerged
Post-Marketing Adverse Reactions

The most freauently reported adverse events in spontonesus post-makketing reports on topiromate incluce:

Psychiotric: somnolence or sedation, hallucination(s), depression, onorexia, acgesssive reaction, psychosis, thinking abnomol, voranciid renction, insomnio, emotional labitity, suivide ante miot, delusion

Central and Peripheral Nervous System: contusion, convulsions oggiovcted, paresthesia, ogitation, speech disorder, otraxia, dizziness, convulsiors, uminesia, heodccha, hyperkinesio

Metabolit and Nutritional: weight deciense

Autonomic Nervous System: vomiting

Vision: vision obnormal

Gostraintestinal: nouseo, dianthea, abdominol poin, constipation

Body as a Whole - General Disorders: fatigue

Urinary System: renal colkulus

Skin and Appendages: rash

\section{SYMPTOMS AND TREATMENT OF OVERDOSAGE}

nocute TOPAWAXX topiromate overdose, if the ingestion is recent, the stomach should be emptied immeciotely by lovage or by induction of emesis. Activated charcoal has not been shown to codsort to:jiramote in vitro. Sherefore, its use in overciosnce is not recommerided. Treatment should be oppropiotely supportive.

Hemodialysis is on effective means of removing topiramote from the body. However, in the few coses of acste overdosage reported, including coses of over $20 \mathrm{~g}$ in one individucl, hemodialysis has not heen necessary.

\section{DOSAGE AND ADMINISTRATION}

General TOPAMAX Tablets or Sprinkle Capsules con be taken witt:out regard to meals. Tablets should not be broken. TOPAMaX Sprinkle Copsules moy

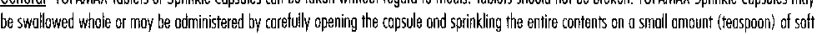
food. This drug/food mixture should be swollowed immediately and not chewed. If should not be stored for future use. The sprinkle formulation is provided for those patients who cannot swallow tablets, e.g. pediantic ond the elderly.

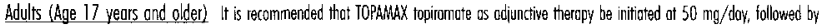

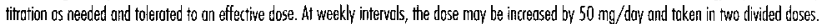
Sonse patients may benefit from lowe iritial doses, e.g. $25 \mathrm{mg}$ and/or a slower fitration schedule. Some potients nay achieve efficacy vith once-sioy dosing.

The recommended totol daly mairtennnce dose is $200 \mathrm{mc}-400 \mathrm{mg} /$ day in two divided coses. Coses sbove $400 \mathrm{mg} /$ day have not been showil to improve responses ond hove been ossociated with a greater incidence of adverse events. The maximum recommended dese is $800 \mathrm{mg} /$ doy. Daily doses obove $1,600 \mathrm{mg}$ have not been studied.

Children (Ages 2-16 yeors) It is reconmended that IOFA, of 1 to $3 \mathrm{mg} / \mathrm{kg} / \mathrm{dog}$ ) nightly for the first week followed by titation as needed ond tolerated to on affective dose. The dossage should then be incerensed of 1 - or 2 -week intervals by increments of 1 to $3 \mathrm{mg} / \mathrm{kg} / \mathrm{coy}$ (odministered in two divided doses). Some patients may benefif from lower initiol doses and/or a slower fitrotion schedule.

The recommended totel dally maintennnce dose is approximately 5 to $9 \mathrm{mg} / \mathrm{kg} /$ doy in two divided deses. Dally doses up to $30 \mathrm{mg} / \mathrm{kg} /$ day hove teen studied and were generolly well talorated.

Geriatrics

Ses PRECaUtions section.

Patients with Renal Impairment

In renally impoired subjects icreatinine clearance less than $70 \mathrm{~mL} / \mathrm{min} / 1.73 \mathrm{~m}$ ), one hatf of the usucl adult dose is recommended. Such potients will require a longet time to rench steady-stote at ench dose.

Palients Undergoing Hemodialysis

Topiramate is cleared by henrodialysis at a rote that is 4 to 6 times greater than a normal individual. According y, 0 prolonged peirod of dialysis moy couse topircmate concentration to fall below that recuired to mointain an ontiseizure effect. To avoid ippid drops in topiromate plasmo concentrotion

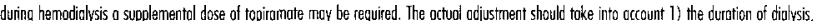
2) the decrance rate of the dinkysis system being usad, and 3) the effective renol clearnonce of topiremote in the partient being dialyzed.

Patients with Heparic Disense

In hepaticolly impcired patients, topiramete plosme concentrations are increased approximotely $30 \%$. This moderate incresse is not considered to

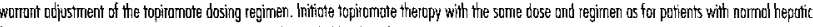
function. The dose fitration in these patients shoud be guided by dlinical cutcome, i.e. seizure cantrol, and aroidance of adverse effects. Such pontents will require o longer time to reach steadystate of each dose.

\section{AVAILABILITY OF DOSAGE FORMS}

IOPAMaX topiramate is available os enthossed tablets in the following strengths os described below:

$25 \mathrm{mg}$ : white, round, cooted tablets containing $25 \mathrm{mg}$ topiramiote.

$100 \mathrm{mg}$ : yel low round coted toblets containing $100 \mathrm{mg}$ topiramate.

$200 \mathrm{mg}$ : salmon-coloured, round, conted tablets rontrining $200 \mathrm{mog}$ tepiramate

IOPAMAX topiromote Sprinkla Caosules contoin smoll white to off-white spheress. The getotin copsules are white ond clear. They are morked as follows:

$15 \mathrm{mg}$ : "TOP" and "15 mg" on the side

$25 \mathrm{mg}$ "TOP" and "25 mg" on the side.

Supplied: Botties of 60 toblets with desiccant. Bottles of 60 copsules without desicant.

IOPAhAX is o Scriedule F Drug.

Product Monograph available to physicions and phormocists upon recuest.

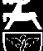

JANSSEN-ORTHO Inc.

Date of issuonce: April 2000

IYP100:0134

2000 IANSSEN-ORTHO InC

* All trademork rights used under litense

Membe 


\section{Laprtor \\ atorvastatin cakium}

\section{power you can trust ${ }^{\mathrm{m}}$}

PLIPITOR*

(atorvastatin calcium)

$10 \mathrm{mg}, 20 \mathrm{mg}, 40 \mathrm{mg}$ and $80 \mathrm{mg}$ tablets

THERAPEUTIC CLASSIFICATION: Lipid Metabolism Regulator

ACTIONS AND CLINICAL PHARMACOLOGY

_PPTOR (atorvastatin cacium) is a synthetic lipid-lowering agent. It is a selective, competitive inhibitor of 3-Fycroxy-3-methyglutaryl-coenzyme A (HMG-COA) reductase. This enzyrre catalyzes the conversion of $M M G-C C A$ to mevalonate, which is an early and rate-limiting step in the biosynthesis of cholesterol.

LIPTOR Iowers plasma cholesterol and lipoprotein levels by inhibiting HMG-COA reductase and cholesterol synthesis in the live and by increasing the number of hepatic Low Density Lipoprotein (LL) receptors on the cell-surface for enhanced uptake and catabolism of Low Density Lipoprctein (LDL)

LPTOR reduces LDL-Cholesterol (LDL-O) and the number of LDL particles. LPPTOR also reduces Very Low Density Lpoprotein Cholesterol MDL-CW, senum triglycerides (IG) and Intermediate Density Lipoproteins (IDL), as well as the number of apoliporrotein B (apo B) containing perticles, but increases High Density Lipocrotein-Cholesterol HDL-C). Elevated serum cholesterol due to elevated LDL-C is a major risk factor tor the development of carciovascular disease. Low serum concentraton of HDL-C is also an independent risk factor. Elevated plasmia TG is also a risk factor for carciovascular dsease, particularly if due to increased IDL, o associated with decreased HDL -C or increased LDL-C

Epidemiologic, clinical and experimental studies have established that high LDL-C, low HDL-C and high plasma TG promote human atheroscterosis and are risk factors for developing cardiovascular disease. Some studies have also shown that the ratio of total cholesterol (total-C) to HDL -C (total-C/HDL.C) is the best predictor of coronary attery disease. In contrast, increased levels of HOL -C are associtad with decreased cardiovascular risk. Drug therapies that reduce levels of $L D L-C$ or decrease $T G$ while simultaneousiy increasing HDL-C have demonstrated reductions in rates of cardlovascular mortality and morbidity.

\section{Pharmacokinetics}

Atorvastatin is rapidly absorbed after ora administration; maximum plasma concentrations occur within 1 to 2 hours. Atonvastatin tablets are $95 \%$ to $99 \%$ bioavailable compared to solutions.

Mean dstribution of atorvastatin is aporoximately 381 liters. Atorvastatin is $\geq 98 \%$ bound to plasma proteins. Atorvastatin is extensively metabolized by cytochrome P-450 $3 A 4$ to ortho- and para-hydrowlated derivatives and to various beta-oxidation products. Approximately $70 \%$ of circulating inhibitory activity for $\mathrm{HMG}$-COA reductase is attributed to active metabolites

Atonastatin and its metabolites are eliminated by billary excretion. Less than $2 \%$ of a dose of atowastatin is recovered in urine following oral administration. Mean plasma elimination nalf-ife of atorvastatin in humans is approximately 14 hours, but the halylife of inhinitory activity for HMG-COA reductase is 20 to 30 hours due to the contribution of longer-lived actve metabolites INDICATIONS AND CLINICAL USE

IPITOR (atorvastatin calcium) is indicated as an adjunct to lifestde changes, including diet (at least equivalent to the Adut Treatment Panel III (ATP III TLC diet), for the recluction of elevated total cholesterol, total-C) ICL-C, TG and apolipoprotein B aco Bi in hyperlipidemic and dyslipidemic conditons, when response to diet and other nonohamacological measures alone has been inadequate, ncluding

- Primary hypercholesterolemia (Type la

- Combined (mixed) hyperipidemia (Type Ib), including familial combined hyperlipidemia, regardless of whether cholesterol or

triglycerides are the lipid abnormality of concern;

- Dysbetalipoproteinemia (Tyce III

- Hypertriglyceridemia (Type lV)

- Familiai hypercholesterolemia (homozygous and heterozygous). For homozygous familial hypercholesterolemia, LFITOR should be used as an adjunct to treatments such as $L O L$ apheresis or as monotherapy if such treatments are rot avaliable

LPITOR also raises HDL-cholesterol and therefore lowers the LOL-CHDL-C and total-CHDL-C ratios in patients with primary hyper-

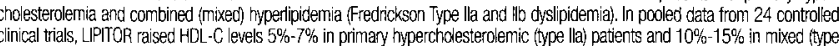
cinical trials, LiP dysip demic patients.

In cinical trials, LPITOR (10 to $80 \mathrm{mg} /$ day) significantly improved lipid profiles in patients with a wide variety of hyperlipidemic and dyslipidemic concitions. In 2 dose-response studies in mildly to moderately hyperlipidemic patients (Fredrickson Types lla and Ilb IIPIOR reduced the levels of total cholesterol $(29-45 \%)$, LDL-C $(39-60 \%)$, apo B (32-50\%), TG $(19-37 \%)$, and increased high density lipoprotein cholesterol (HDL-C) levels (5-9\%). Comparable responses were achieved in patients with heterozygous familia hypercholesterolemia, non-tamillal forms of hypercholesterolemia, combined hyperlipidemia including farmilial combined hyperlipidemia and patients with non-insulin dependent diabetes mellitus. In patients with hypertriglyceridemia (Type M, LPITOR (10 to
$80 \mathrm{mg}$ dally, reduced TG (25- 56\%) and LDL-C levels $23-40 \%$. LPITOR has not been studied in conditions where the major abnormality is elevation of chylomicrons (TG ievels $>11$ mmoll), i.e., types $\mid$ and $V$.

In an open-label study in patients with dysbetailioproteinemia (Type II), LPPTOR (10 to $80 \mathrm{mg}$ daliy) reduced total-C $(40-57 \%)$, TG $(40-56 \%)$ and DL $-C+$ VLDL-C levels $(34-58 \%)$.

In an open label study in patients with homozycous familial hypercholesterolemia (FH) LIPTOR (10 to $80 \mathrm{mg}$ daily) reduced mean $\mathrm{LLL}-\mathrm{C}$ levels $(22 \%)$. In a piot study, LIPTOR 80 mg/day showed a mean LLL-C lowering of $30 \%$ for patients not on pasmapheresis and of $31 \%$ for patients who continued plasmapheresis. A mean LDL-C lowerning of $35 \%$
receptor defective patients and of $19 \%$ in receptor negative patients isee PHARMACOLOGY Clirical Studies).

For more details on efficacy results by pre-defined classification and pooled data by Fredrickson types, see PHARMACOLOGY, Clinical Studies

Pricr to initating theraoy with LPITOR, secondary causes should be excluded for elevations in plasma lipid levels (e.g. poorly controlled diabetes melltus, hypothyroidism, nephrotic syncrome, dysproteinemias, cbstructive liver disease, and aicoholism), and a lipid profie performed to measure total cholestercl, $\mathrm{LDL}-\mathrm{C}, \mathrm{HDL}-\mathrm{C}$, and $\mathrm{TG}$. For patients with $\mathrm{TG}<4.52$ m mriol $/ \mathrm{L}(\mathrm{K} 400 \mathrm{mg} / \mathrm{dL})$, a lipid profis pertormed to meas be estimated tsing the following equation:

LDL $-\mathrm{C}(\mathrm{mm}$ iol $)=$ total-C $-[(0.37 \times(\mathrm{TG})+\mathrm{HCL}-\mathrm{C})$

$L \mathrm{LL}-\mathrm{C}(\mathrm{mg} / \mathrm{dL})=$ total $-\mathrm{C}-[(0.2 \times(\mathrm{TG})+\mathrm{HDL}-\mathrm{C})]$

For patients with Ta levels $>4.52 \mathrm{mmol} / \mathrm{L}(>400 \mathrm{~m} / \mathrm{dLL}$, this equation is less accurate and $\mathrm{LDL}-\mathrm{C}$ concentrations should be measured directly or by ultracentrifucation.

Patients with high or very high triglyceride levels, i.e. $>2.2 \mathrm{mmoh}(200 \mathrm{mg} / \mathrm{d} L$ ) or $>5.6 \mathrm{~m}$ mol/ $\mathrm{L}(500 \mathrm{mg} / \mathrm{d}$ ), respectively, may require triglyceride lowering therapy (tenofibrate, bezafbrate or nicotinic acic) alone or in combination with LPITOR.

In general, combination therapy with fibrates must be undertaken cautiously and only after risk-benefit analysis (see WAPNNINGS, Muscle EHects, PRECAUTIONS, Pharmacokinetic Interaction Studes and Potentia Drug Interactions).

Eievated serum triglycerides are most often observed in patients with the metabolic syndrome fabdominal obesity, atherogenic dyslipidema (elevated triglycerides, smal dense LDL partices and tow HDL-cholestero\}, insulin resistance with or without glucose intoerance, raised blood pressure and prothrombic and proinflammatory states;

(For the treatment of soecific dysilipidemias reter to the Report of the Canadian Working Group on Hypercholesterolemia and Other Dyslipidemias or to the US NCEP Exoert Panel on Detection, Evaluation, and Treatment of Hign Blood Cholesterol in Aduts [Adut Treatment Panel

When drugs are prescribed attention to therapeutic lifestyle changes ireduced intake of saturated tats and cholesterol, weight reduction, increased physical activity, ingestion of scluble fibers) should always be maintained and reinforced.

The Atorrastatin Versus Revascularzation Treatments (AVERT) study examined the effect of intens se lipid-lowering in patients with stable corconary artery disease and LDL-C at least 3.0 mmolh in patients referred for percutaneous transuminal coronary angioplasty
PTCA. Patients were randomised for 18 months to LPITOR $80 \mathrm{mg}$ daily or to PTCA with LsLal medical care which could include lipid metabolism regulators. The results of the AVERT study should be considered as exploratory since several limitations may affect its metabolism regulators. The results of the AVERT study should be considered as exploratory since several imitations may affect its
design and conduct in the medica-treated group with LIPTOR there was a trend for a reduced incidence of ischemic events and a
delayed time to first ischemic event. The results also suggest that intersive treatment to target LCL-C levels with LPTTOR is additive

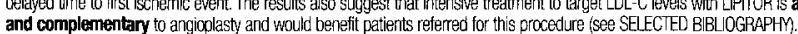
CONTRAINDICATIONS

Hypersensitivity to any component of this medication.

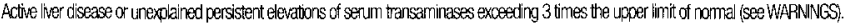
Pregnancy and lactation (see PRECAUTIONS)

\section{WARNINGS}

Pharmacokinetic Interactions

The use of HMG-CaA reductase inhioitors has been associated with severe myopathy, including inabdomyolysis, which may be more trequent when they are co-acministered with drugs that inhibit the cylochrome $\mathrm{P}-450$ enzyme system. Atorvastatin is metabolized by cytochrome P-450 isoform $3 A 4$ and as such may interact with agents that inhibit this enzyme. (See WARNINGS, Muscle effects and PRECAUTIONS, Drug Interactions and Cytochrome P-450-mediated Interactions).

\section{Hepatic Effects}

In clinical trals, persistent increases in senum transaminases greater than three times the upper limit of normal occurred in $1 \%$ of patients who received $\triangle P P F O R$. When the dosage of $L$ IPTCR was reduced, or when drug treatment was interrupted or discontinued serum transaminase levels returned to pratreatment levels. The increases were generally not associated with jaundire or other clinical signs or symptoms. Nost patients continued treatment with a reduced dose of LIPTOR without clinical secuelae. Lver function tests should be performed before the initiation of treatment, and periodically thereafter. Special attention should be paid to patients who develop elevated serum transaminase levels, and in these patients measurements should be repeated prompity and then performed more frequentily

If increases in alanine aminotransferase (ALT) or aspartate aminotransferase (AST) show evidence of progression, particularly if they rise to greater than 3 times the upper limit of normal and are persistent, the dosage should be reduced of the drug discontinued.

LPITOR should be used with caution in patients who consume substantal quantities of alcohol and/or have a past history of Iver disease. Active liver cisease or unexplained transaminase elevations are contraindications to the use of LIFITOR; if such a condition should develop during therapy, the drug should be discontinued.

Muscle Effects

Myopathy, defined as muscle aching or muscle weakness in conjunction with increases in creatinne phosphokinase (CPK) vaues o greater than ten tin or weakness, and or marked elevation of uPK. Padents should be advised to report prompuly unexplanined muscle pain, tendernes or weakness, particularly if accompanied by malaise or fever. LPITOR therapy should be discontinued if makedly elevated CPK levels occur or myopathy is diagnosed or suspected.

The risk of myopathy and thabdomylysis during treatment with HMG-COA reductase inhibitcrs is increased with concurrent

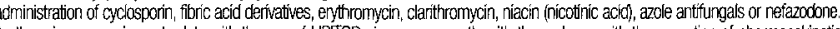
As there is no experience to date with the use of LPTTOR given concurrently with these dnigs, with the exception of phamacokinetic studies cond ucted in healthy subiects with en thromycin and clanthromycin the benefits and risks of such combined therany should be carefully considered (see PRECAUTIONS, Phammacokinetic Interaction Studies and Potential Drug Interactions).

Rhabdomyolysis has been reported in very rare cases with LPITOR (see PRECAUTIONS, Drug Interactions).

Rhabdomyolysis with renal dystunction secondary to myoglobinuria has also been reported with HMG-COA reductase inhibitors. LIPIOR therapy should be temporarily withheld or discontinued in any patient with an acute serous condition suggestive of a myocathy or thaving a risk factor predisposing to the development of renal tallure secondary to thabdomyolysis isuch as severe acite infection, hyootension, major surgery, trauma, severe metabolic, endocrine and electrolyte disorders, and uncontrolled seizures).

\section{PRECAUTIONS}

General

Before instituting therapy witt LPPTOR (atorvastatin calcium), an attempt should be made to control elevated serum lipoproten levels with appropriate det, exercse, and weight reduction in overweight patents, and to treat oher underlying medical probiem (see NDICATIONS AND CLINICAL USE). Patients should be advised to inform subsequent physicians of the prior use of LiPTTOR or any other lipid-lowering agents.

\section{Effect on the Lens}

Current long-term data from clinical trials do not indicate an adverse effect of atorvastatin on the human lens.

\section{Effect on Ubiouinone ( $\mathrm{CoO}$ to) Levels}

anicant decraas in circuiting biquinone levels in patients treated with atorvastatin and other statins have been obseved. The clinical significance of a potential long-term statin-induced deficiency of ubiquincone has rot been established. It has teen morted that a decrease in myocardial ubiquinore levels could lead to impaired cardiac function in patients with borderine congestive hear tailure (See SELECTED BBLLOCRAPHY).

Effect on Lipoprotein (a)

in some patents, the beneficial effect of lowered total cholesterol and LDL-C levels may be partly blunted by a concomitant increase $L$ (a) lipoprotein concentrations. Fresent knowledge suggests the importance of hich $L(a)$ levels as an emerging risk factor for coronary heart disease. It is thus desirable to maintain and reinforce lifestyle changes in high risk patients placed on atorvastatin therapy (SEe SELECTED BIBLLOGPAPHY)

Hypersensitivity

An apsarent hypersensitivity syndrome has been repoted with other HMG-COA reductase inhibitors which has included 1 or more of the following features: anapny axis, angioedema, lupus enthematous-like syndrome, Dolymyalgia rheumatica vasculitis (t) Stevens-Johnson syndrome. Athough to date hypersensitivity syndrame has not been described as such, LIPITOR should be discontinued if hycersensitivity is suspected

\section{Use in Pregnancy}

UPITOR is contraindicated during pregnancy (see CONTRAINDICATIONS)

Atherosclerosis is a chronic process and discontinuation of llipid-lowering drugs during pregrancy should have little impact on the outcome of long-term therapy of primary hypercholesterolemia. Cholesterol and other products of cholesterol biosynthesis are essential components for fetal developrrent (including synthesis of sterrids and cell membranes). Since HMG-CoA reductase mhibtors decrease cholesterol synthesis and possibly the synthesis of other biologically actlve substances derived from cholesterol they may cause harm to the fetus when admiristered to pregnant women.

There are ro data on the use of LPTTOR during pregnancy. LPTTOR should be administered to women of childbearing age only when such patients are highly unlikely to conceive and have been informed of the potential hazards. It the patient becomes pregnant while taking LIPITOR, the drug should be discontinued and the patient apprised of the potential risk to the fetus. Nursing Mothers

In rats, milk concentrations of atorvastatin are similar to those in plasma. It is not known whether this drug is excreted in human milk. Because of the potential for adverse reactions in nursing infants, women taking LPITOR should not breast-feed (see CONTRAINDICATIONS)

Pediatric Use

Treatment experience in a peciatric population is limited to doses of LIPTOR up to $80 \mathrm{mg} /$ day for 1 year in 8 patients with homozygous familial hypercholesterolemia. No clinical or biochemical abnormalities were reported in these patients. Geriatric Use

Treatment experlence in adults 70 years or older ( $N=221)$ with doses of LPITOR up to $80 \mathrm{mg}$ day has demonstrated that the safety and effectiveness of atorvastatin in this population was similar to that of patients $<70$ years of age. Pharmacokinetic lowest dose should be administered initially (see PHARMACOLOGY, HUman Pharmacokinetics; SELECTED BIBLOGOGAPHM.

\section{Renal Insufficiency}

Plasma concentrations and LDL-C lowering efficacy of LIPITOR was shown to be similar in patients with moderate rena insufficiency compared with patients with normal renal function. However, since several cases of thabdomyolysis have been reported in patients with a history of renal insufiticiency of unknown severity, as a precautionary measure and pencing turther experience in renal disease, the lowest dose (10 $\mathrm{mg} /$ dayy of $\$ PTOR should be used in these patients. Simiar precautions acoly in patients with severe renal insufficiency [creatinine clearance $<30 \mathrm{~mL} / \mathrm{min}(<0.5 \mathrm{~mL} / \mathrm{sec})$ ]; the lowest dosage should be used and implemented cautiously isee WARNINGS, Muscle Effects; PRECAUTIONS, Drug interactions.

Tefor also to DOSAGE AND ADMUNISTRATION.

\section{Endocrine Function}

MMG-COA reductase inhibitors interfere with cholesterol synthesis and as such might theoretically blunt adrenal and/or gonad seroid production. Cinical stues with atorvastatin and other HMG-COA reductase inhibitors have suggested that these agents not reduce plasma cortisol concentration or impar adrenal resenve and do not reduce basal plasma testosterone concentration However, the effects of HMG-COA reductase inhibitors on male fertility have not been studied in adecuate rumbers of patients. The effects, if any, on the pittuitany-gonadal axis in premenopausal women are unknown.

Patients treated with atorvastatin who develop clinical evidence of endocrine dysfunction should be evaluated appropriately. Caution should be exercised if an HMG-COA reductase inhibitor or other agent used to lower cholesterol levels is administered to patients receiving other drugs (e.g. ketoconazole, spironolactore or cimetidine) that may decrease the levels of endogenous steroid hormones. 


\section{Pharmacokinetic Interaction Studies and Potential Dnug Interactions}

Pharmacokinetic interaction studies conducted with drugs in healthy subjects may not cetect the possibility of a potential dug interaction in some catents due to difterences in undertigng diseases and use of concomitant medications (see also Geriatric use Renal Insutficiency: Pajients with Severe Hypercholesteroiemla).

Concomitant Therapy with Other Lipid Metabolism Regulators: Combined drug therapy should be approached with caution as information from controlled studies is limited.

\section{Bile Acid Sequestrants:}

Patients with mild to moderate hypercholesterolemia: LDL-C reduction was creater when LIPITOR $10 \mathrm{mg}$ and colestipol $20 \mathrm{~g}$ were coadministered $(-45 \%)$ than when either drug was administered alone $(-35 \%$ for LIPITOR and $-22 \%$ for colestipol).

Patents with severe hypercholesterolemia: LDL-C reduction was similar (-53\%) when LIPTOR $40 \mathrm{mg}$ and colestipol $20 \mathrm{~g}$ were coadministered when compared to that with LPITOR $80 \mathrm{mg}$ aione. Plasma concentration of atorvastatin was lower (approximatey $26 \%$ ) when $L P P T O R 40 \mathrm{mg}$ plus colestipol $20 \mathrm{~g}$ were ccadministered compared with $\mathrm{LPT} T \mathrm{OR} 40 \mathrm{mg}$ alone.

However, the combination drug therapy was less effective in lowering the triglycerides than LIFTOR monotherapy in both types of hypercholesterolemic patients (see PHARMACOLOGY, Clinical Studies).

When LPTTOR is used concurrently with colestipol or any other resin, an interval of at least 2 hours should be maintained between the two drugs, since the absorption of LPTTOR may be impaired by the resin.

Fibric Acid Derivatives (Gemfibrozil, Fenofibrate, Bezafibrate) and Niacin (Nicotinic Acid): Althougn there is limited experience with the use of LPITR given concurrently wth fibric actd derivatves and niacin, the benefts and risks of sudh atorvastatin, is increased with concurrent administration (see WARNNAGS, Muscle Effects and SELECTED BIBLLOGRAPHY).

Coumarin Anticoagulants: LPITOR had no clinically significant effect on prothrombin time when administered to patients receiving chronic warfarin therapy (see SELECTED BIBLLOGRAPHY).

Digoxin: In healthy subjects, digoxin pharmacckinetics at steady-state were not significantly attered by coadministration of digoxin $0.25 \mathrm{mg}$ and LPTTOR $10 \mathrm{mg}$ daily. However, digoxin steady-state concentrations increased aporoximately $20 \%$ followng coadministration of digoxin $0.25 \mathrm{mg}$ and LPTTOR $80 \mathrm{mg}$ daly (see Human Phamnacokinetics). Patients taking digoxin should be monitored appropriately.

Anthypertensive agents (amlodipine): In clinical studies, LPITOR was used concomitanty with anthypertensive agents without evidence to cate of clinically sigrificant adverse interactions. In healthy subjects, atorvastatin phamacckinetics were no: altered by the coadministration of LPTTOR $80 \mathrm{mg}$ and amiodipine $10 \mathrm{mg}$ at steady state (see Human Pharmacokinetics).

(quinapril): In a randomized, open-label stuoy in healthy subjects, steady-state quinapril dosing $(80 \mathrm{mg} Q \mathrm{QD})$ did not significantly affect the pharmacokinetic profile of atorvastatin tablets $(10 \mathrm{mg} \mathrm{QD}$ ) (see Human Pharmacokinetics.

Oral Contraceptives and Hormone Replacement Therapy: Coadministration of LiPITOR with an oral contraceptive containing 1 mg norethindrone and $35 \mu \mathrm{g}$ ethinyl estradiol, increased plasmia concentrations (AJC eveisi) of norethindrone an ethinyl estradiol by asproximately $30 \%$ and $20 \%$, respectively. These increases should be considered when selecting an ora contraceptive. In clinical studies, LIPTOR was used concomitantly with estrogen replacement therapy without evidence to date of dinically significant adverse interactions.

Antacids: Administration of auminum and magnesium based antacids, such as Maalox, TC Suspension, with L.PITOR decreased plasma concentrations of LPPTOR by approximately $35 \%$. LDL-C reduction was not altered but the triglyceride-lowering effect of LPTOR may be affected.

Cimetidine: Adrininistration of cimetidne with LIPITOR did not atter plasma concentrations or LDL-C lowering efficacy of LIPTOR however, the trighyceride-lowering effect of LPITOR was reduced from $34 \%$ to $26 \%$

Gytochrome P-450-mediated Interactions: Atorvastatin is metabolized by the cytochrome P-450 isoenzyme, CYP 3A4 Enthromycin a CYP 3 A4 inhibitor, increased atorvastatin plasma levels by $4 \mathrm{C} \%$. Coadministration of CYP 3 A4 inhibitors, such as grapefrut juice, some macrolde antibiotics (i.e. enythromycin, clarithromycin), immunosuporessants (cyclosporine), azole antifungal agents (i.e. itraconazole, ketoconazole), protease inhibitors, or the antidepressant, refazodone, may have the potential to increase plasma concentrations of HVG-COA reductase inhibitors, including LPITOR (see SELECTED BIBLIOGRAPHY). Caution should thus be exercised with concomitant use of these agents (see WARNN NGS, Pharmacokinetic Interactions, Muscle Effects; PRECAUTIONS, Renal Insufficiency and Endocrine Function; DOSAGE AND ADMINISTRATION; SELECTED BIBLOGRAPHY?

In healthy subjects, coadministrajion of maximum doses of both atorvastatin $(80 \mathrm{mg})$ and terfenadine $(120 \mathrm{mg})$, a CYP $3 A 4$ substrate, was shown to produce a modest increase in terfenadine AUC. The QTC interval remained unchanced. However, since an interaction between these two drugs cannot be excluded in patients with predisposing factors for anhythmia, (e.g. preexisting prolonged QT interval, severe coronary atery disease, hypokalemia), caution should bo exercised when these agents are coadministered (see WARNNNGS, Pharmacokinetic Interactions; DOSAGE AND ADMNINISTRATION)

Antipyrine: Antipyrine was used as a non-specific model for dugs melabolized by the microsomal hepatic enzyme system (cytochrome P-450 system). LPTTOR had no effect on the pharmacokinetics of antipyrine, thus interactions with other drug metabolized via the same cytochrome isozymes are not expected.

Macrolide Antiblotics (az/thromycin, clarithromycin, erythromycin): In healthy adults, coadministration of LPITOR $110 \mathrm{mg}$ QDi and azittromycin (500 $\mathrm{mg} Q \mathrm{QD}$ ) did not significaritly atter the plasma concentrations of atorvastatin. However, coadministration of atorvastatin (10 mg QD) with erythromycin (500 mg QD) or clarthromycin (500 mg BD), which are both CYP $3 A 4$ inthibitors,
increased plasma concentrations of atorvastatin approximately $40 \%$ and $80 \%$, respectively (see WAPNINGS, Muscle Effects; Human Pharmacokinetics).

Protease Inhibitors (nelfinavir mesylate): In healthy adults, ccadministration of nelfinavir mesylate (1250 $\mathrm{mg}$ BiD), a known CYP $3 A 4$ inhibitor, and atorvastatin (10 mo QD) resulted in increased plasma concentraions of atorvastatin. AUC and Cmax of atorvastatin were increased by $74 \%$ and $122 \%$ respectively.

Patients with Severe Hvpercholesterolemiai Higher drug dosages $80 \mathrm{mg} /$ day) required for some patients with severe hypercholesterolemia including familal hypercholesterolemia) are associated with increased plasma ievels of atomastatin. Caution should be exercised in such patients who are also severely renally impaired, elderty, or are concomitantly being administered digoxin or CYP 3 A4 inhibitors (see WARNINGS, Pharmacokinetic interactions, Muscle Effects PRECAUTIONS, Drug Interactions; DOSAGE AND ADMNISTRATION).

\section{Dnug/Laboratory Test Interaction}

LIPTOR may elevate serum transaminase and creatinine phosphokinase levels (from skeletal muscle). in the differential diagnosis of chest pain in a patient on therapy with LFITOR, cardiac and noncardiac fractions of these enzymes should be deterrmined. ADVERSE REACTIONS

LPITOR is generally well-tolerated. Adverse reactions have usually been mild and transient. in controlied cinical studies iplacebocontroled and active-controlled comparative studies with other lipid lowering agents) involving 2502 patients, $<2 \%$ of patients were discontinued due to adverse experiences attributable to LIPITOR. Of these 2502 patients, 1721 were treated for at least 6 months and 1253 for 1 year or more

Adverse experiences occuring at an incidence $\geq 1 \%$ in patients participating in placebo-controlled clinical studies of LPITOR and reported to be possibly, probably or definitely drug related are shown in Table 1 below:

TABLE 1. Associated Adverse Events Reported in $\geq 1 \%$ of Patients in Placebo-Controlled Clinical Trials

\begin{tabular}{rcc}
\hline & Placebo \% $(\mathrm{n}=270)$ & LPITOR \% $(\mathrm{n}=1122)$ \\
\hline GASTROINIESTINAL & 1 & 1 \\
Constipation & 1 & 1 \\
Diarnea & 2 & 1 \\
Dyspepsia & 2 & 1 \\
Flatulence & 0 & 1 \\
Naulsea & 2 & 1 \\
NERVOUS SYSTEM & & \\
Headache & $<1$ & 1 \\
MISCELLANEOUS & 1 & 1 \\
Pain & $<1$ & 1 \\
Myalgia & & \\
Asthenia & &
\end{tabular}

The following additional adverse events were reported in clinical trials; not al events listed below have been asscciated with a causal relationship to LIPITOR therapy: Muscle cramps, myositis, myopathy, paresthesia, peripheral neuropathy, pancreattis, hepatitis, cholestatic jaundice, anorexia, vomiting, alopecia, pruritus, rash, impotence, hyperglycemia, and hypoglycemia

Post-marketing experience: Very rare reports: severe myopathy with or without mabdomyolysis (see WARNNNGS, Muscle Ettects; PRECALTIONS, Renal Insufficiency and Drug Interactions). Isolated reports: thrombocyopenia, athralgia and alergic reactions including urtcario angioneurotic edema ananhydaxis and bullous rashes fincluding entheme multifome Stevens-Johno syndrome and toxic epidemal necrolysiss). These may have no causal relationship to atorvastatin.

Ophthalmiologic observations: see PRECAUTIONS.
Laboratony Tests: Increases in serum transaminase leves have been noted in clinical triais (see WARNNING). SYMPTOMS AND TREATMENT OF OVERDOSAGE

These is no specific treatment for atorvastatin overdosage. Should an overdose occur, the patient should be treated symotomatically and supportive measures instituted as required. Cue to extersivive drug binding to plasma proteins, hemodialysis is not expected to and supportive measures instituted as required
significantly enhance atorvastatin clearance.

\section{DOSAGE AND ADMINISTRATION}

Patients should be placed on a standard cholesternt-lowering diet gat least equivalent to the Adult Treatment Panel II (ATP III) TLC cietl before receiving LPITOR, and should continue on this diet during treatment with LPITOR, If aporopriate, a program of weight control and physical exercise should be implemented.

Primary Hypercholesterolemia and Combired (Mxed) Dyslipidemia, Including Familial Combined Hyperinidemia

The recommended stating dose of $L P T O R$ is 10 or $20 \mathrm{mg}$ once daily. Patients who require a large reduction in LDL-C (more than $45 \%$ ) may be started at $40 \mathrm{mg}$ once cally. The dosage range of LPITOR is 10 to $80 \mathrm{mg}$ once dally. Doses can be given at any tin of the day, with or without food, and should preferaoly be given in the evening. Doses shoud be individual zed according to the leve of risk; the baseline LDL-C and/or TG levels; the LOL-C, TG and/or total-C/HDL-C targets (see the Detection and Management of Hyercholesterolemia, Working Grouo on Hyoercholesterolemila and other Dysipidemias [Canadal and/or the US Nation Cholesterol Education Program (NCEP Adult Treatment Panel III); the goed of therapy; and the pationt's response. A significant therapeutic response is evicent within two weeks, and the maximum response is usually achieved within two to four weeks. The response is maintained during chronic therapy. Adjustments of dosage, it necessary, should be made at intervals of two to fou weeks. The maximum dose is 80 mg/day.

Lipjd levels should be monitored periodically and, if necessary, the dose of LIPITOR adjustod based on target lipid levels recommended by guidelines.

The following reductions in total cholestercl and LDL-C levels have been observed in 2 dose-response studies, and may serve as a guide to treatment of patients with mild to moderate hypercholesterolemia

TABLE 2. Dose-Response in Patients With Mild to Moderate Hypercholesterolemia Mean Percent Change from Baseline

\begin{tabular}{|c|c|c|c|c|}
\hline \multirow{2}{*}{ Lipid Parameter } & \multicolumn{4}{|c|}{ LIPITOR Dose (mg/day) } \\
\hline & $\begin{array}{c}10 \\
N=22)\end{array}$ & $\begin{array}{c}20 \\
(\mathrm{~N}=20)\end{array}$ & $\begin{array}{c}40 \\
(N=21)\end{array}$ & $\begin{array}{c}80 \\
(N=23)\end{array}$ \\
\hline $\begin{array}{l}\text { Total-C: } 7.1 \mathrm{mmo} / \mathrm{L}^{\mathrm{D}} \\
{[273 \mathrm{mg} / \mathrm{dl}\}^{6}}\end{array}$ & -29 & -33 & -37 & -45 \\
\hline $\begin{array}{l}\text { DL-C: } 4.9 \mathrm{mmo} / \mathrm{h}^{\mathrm{b}} \\
\left(190 \mathrm{mg} / \mathrm{dL} \mathrm{i}^{\mathrm{b}}\right.\end{array}$ & -39 & -43 & -50 & -60 \\
\hline
\end{tabular}

$(190 \mathrm{mo} / \mathrm{dL}$

a. Results are pooled from 2 dose-response studies.

b. Mean baseline values.

\section{Severe Dyslipidemias}

In patients with severe dyslipidemias, including homozygous and heterozygous tamilial hypercholesterdemia and dysbetal poprotenemia (Type III, hicher dosages (up to 80 mo,day) may be required isee WARNINGGS, Pharmacckinetic Interactions, Muscie Effects; PRECAIJTONS, Drug Interactionsi.

\section{Concomitant Therapy}

See PRECAUTIONS, Drug Interactions.

Dosage in Patients With Renal Insufficiency

SeE PRECAUTIONS.

\section{PHARMACEUTICAL INFORMATION}

\section{Drug Substance}

Proper Name: Atorvastatin calcium

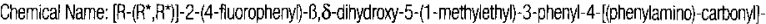
$1 \mathrm{H}$-pyrrole-1-heptanoic acid, calcium sait (2:1) trihydrate

Empirical Formula: $\left(\mathrm{C}_{33} \mathrm{H}_{34} \mathrm{FN}_{2} \mathrm{O}_{5} / 2 \mathrm{Ca} * 3 \mathrm{H}_{2} \mathrm{O}\right.$

Molecular Weight: 1209.42

Structural Formula:

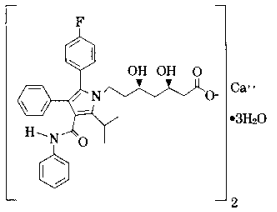

Description: Atorvastatin calcium is a white to oft-white cn'stalline powder that is practically insoluble in aqueous solutions of $\mathrm{pH} 4$ and below. Atorvastatin calcium is very sightily scluble in distiled water, pH 7.4 phosphate buffer and acetonitrle, slightly soluble in ethanol, and freely solubie in methanol.

Tablet Composition:

Each tablet contains either $10 \mathrm{mg}, 20 \mathrm{mg}, 40 \mathrm{mg}$ or $80 \mathrm{mg}$ atorvastatin as the active ingredient. Each tablet also contains the following non-medicinal ingredients: calcium carbonate, candelilla wax, croscarmellose sodium, hydroxypropyl celluose, lactose monohydrate, magnesium stearate, microcrystalline celluluse, hydroxypropyl methylcellulose, polyethyene glycol, talc, titanium dioxide, polysorbate 80 and simethicone emulsio

Stability and Storage Recommendations:

Store at controlled room temperature 15 to $30^{\circ} \mathrm{C}$

\section{AVALABILITY OF DOSAGE FORMS}

LPTTOR (atorvastatin calcium) is avalable in dosage strengths of $10 \mathrm{mg}, 20 \mathrm{mg}, 40 \mathrm{mg}$ and $80 \mathrm{mg}$ atorvastatin per tablet. $10 \mathrm{mg}$ : White, elliptical, flm-coated tablet, coded "10" on one side and "PD 155" on the other. Avaiable in bottles of 90 tablets.

$20 \mathrm{mg}$ : White, elliptica, film-coated tablet, coded "20" on one side and "PD 156" on the other. Availabie in bottles of 90 tablets. $40 \mathrm{mg}$ : White, elliptical, flm-coated tablet, coded "40" on one side and "PD 157 " on the cther. Avalable in botties of 90 tablets. $80 \mathrm{mg}$ : White, elliptical, film-ccated tablet, coded " 80 " on one side and "PD 158 " on the other. Available in blisters of 30 tab:ets (3 strips $\times 10$ ).

References:

1. LPTTOR (atcrvastatin calcium) Product Monograph, Pfizer Canada inc, August 2003. 2. MS Health MDAS; March 1997 Varch 2003. 3. Pitt B, Waters D, Brown W et al. Aggressive I pid-lowering theraoy compared with angioplasty in stable corona artery disease. N Engl J Med 1999;341:70-76. 4. Data on File, Ptizer Canada Inc. 5. Simon Day. Dictionary for Clinical Trials 1999, John Wiley \& Sons Ltd. Pages 137-38

For a copy of the Product Monograph or full Prescribing Information, please contact:

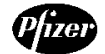

Life ts our life's wort

02004

fizer Canada inc.

Kirkland,
H9J $2 \mathrm{MS}$

'TM Pfizer Ireland Pharmaceuticak

Pfizer Canada Inc. licensee

$\widehat{P A A B}$

Member 
NEW

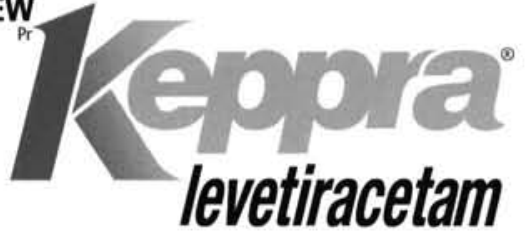

CONNECTING EXCELLENT PROFILES IN EFFICACY AND TOLERABILITY

PRESCRIBING INFORMATION

Tablets of $250 \mathrm{mg}, 500 \mathrm{mg}$, and $750 \mathrm{mg}$

Therapeutic classification: Antiepileptic

ACTIONS AND CUINICAL PHARMACOLOGY

Mechanism of Action

Levetiracetam is a drug of the pyrrolidine class chemically unrelated seizure and antiepileptogenic activity in several models of chroni epilepsy in both mice and rats, while being devoid of anticonvulsant activity in the classical screening models of acute seizures.

The mechanism of action of levetiracetam has not yet been fully established, however, it appears to be unlike that of the commonly established, however, it appears to be unlike that of the commonly of up to $10 \mu \mathrm{M}$ did not result in significant ligand displacement at known receptor sites such as benzodiazepine, CABA (gamma aminobutyric acid), glycine, NMDA ( $\mathrm{N}$-methyl-D-aspartate), reuptake sites or second messenger systems. Furthermore,
levetiracetam does not modulate neuronal voltage-gated sodium levetiracetam does not modulate neuronal voltage-gated sodium and T-type calcium currents and
tacilitation of the CABAergic system.

Pharmacokinetics

Summary: Single-and multiple-dose pharmacokinetics of levetiracetam have included healthy volunteers, adult and pediatric patients with epilepsy, elderly subjects, and subjects with renal and patientic impairment Results of these studies indicate that levetiracetam is rapidly and almost completely absorbed after oral administration The pharmacokinetic profile is linear with low intraand inter-subject variability. There is no modification of the clearance after repeated adminisistration. Food does not affect the extent of after repeated administration. Food does not affect the extent of absorption of levetiracetam, although the rate is decreased
Levetiracetam is not protein-bound ( $<10 \%$ bound) and its volume of Levetiracetam is not protein-bound ( $<10 \%$ bound) and its volume
distribution is close to the volume of intracellular and extracellula distribution is close to the volume of intracellular and extracellula water. Sixty-six percent (66\%) of the dose is renally excrete unchanged. The major metabolic pathway of levetiracetam (24\% o the dose) is an enzymatic hydrolysis of the acetamide group. It is no liver cytochrome P450 dependent. The metabolites have no known pharmacodynamic activity and are renally excreted. Plasma half-liie of levetiracetam across studies is $6-8$ hours. Plasma half-life is increased in subjects with renal impair

Based on its pharmacokinetic characteristics, levetiracetam is unlikely to produce or to be subject to metabolic interactions.

The pharmacokinetic profile is comparable in healthy volunteers and in patients with epilepsy.

Due to its complete and linear absorption, plasma levels can be predicted from the oral dose of levetiracetam expressed as $\mathrm{mg} / \mathrm{kg}$ bodyweight. Therefore, there is no need for plasma level monitoring of levetiracetam.

Human Pharmacology

Pharmacokinetics: The pharmacokinetics of levetiracetam have been characterized in single and multiple dose PK studies, with doses up to $5000 \mathrm{mg}$; these studies included healthy volunteers $(n=98)$, patients with epilepsy ( $n=58$ adult patients and $n=24$ pediatric patients), elderly subjects $(n=16)$ and subjects with renal and hepatic impairment ( $n=36$ and 16 , respectively)

Absorption and Distribution: Levetiracetam is rapidly and almost completely absorbed after oral administration. The ora bioavailability of levetiracetam tablets is $100 \%$. Plasma peak concentrations ( $C_{\mathrm{m}}$ ) are achieved at 1.3 hours after dosing. The extent of absorption is independent of both dose and the presence of food, but the latter delays $T_{\max }$ by 1.5 hours and decreases $C_{\max }$ by 20\%. The pharmacokinetics of levetiracetam are linear over the dose range of $500-5000 \mathrm{mg}$. Steady-state is achieved after two days of a twice daily administration schedule. Mean peak concentrations
$\left(C_{\max }\right)$ are 31 and $43 \mu g / \mathrm{mL}$, respectively, following a single $1000 \mathrm{mg}$ dose, and a repeated $1000 \mathrm{mg}$ twice daily dose.

Neither levetiracetam nor its primary metabolite is significantly bound to plasma proteins $(<10 \%)$. The volume of distribution of levetiracetam is approximately 0.5 to $0.7 \mathrm{~L} / \mathrm{kg}$, a value that is close to the total body water volume. No tissue distribution data for humans are available.

Metabolism: Levetiracetam is not extensively metabolized in humans. The major metabolic pathway is the enzymatic hydrolysis of the acetamide group, which produces the pharmacologically of the acetamide group, which produces the pharmacologically
inactive carboxylic acid metabolite, ucc 1057 (24\% of dose). The production of this metabolite is not dependent on any liver production of this metabolite is not dependent on any liver
cytochrome $\mathrm{P} 450$ isoenzymes and is mediated by serine esterase(s) cytochrome $P 450$ isoenzymes and is mediated by serine esterase(s)
in various tissues, including blood cells. Two minor metabolites were identified as the product of hydroxylation of the 2-oxo-pyrrolidine ring ( $2 \%$ of dose) and opening of the 2 -oxo-pyrrolidine ring in
position 5 ( $1 \%$ of dose). There is no evidence for enantiomeric interconversion of levetiracetam or its major metabolite

Elimination: Levetiracetam plasma half-life in adults is $7 \pm 1$ hours and was unaffected by dose, route of administration or repeated administration. Levetiracetam is eliminated from the systemic circulation by renal excretion as unchanged drug, which represents $66 \%$ of administered dose. The total body clearance is $0.96 \mathrm{~mL} / \mathrm{min} / \mathrm{kg}$ and the renal clearance is $0.6 \mathrm{~mL} / \mathrm{min} / \mathrm{kg}$. Approximately $93 \%$ of the gose was excreted within 48 hours. The mechanism of excretion is glomerular fittration with subsequent partial tubular reabsorption. The
primary metabolite, ucb 1057 , is excreted by glomerular filtration and primary metabolite, uct
active tubular secretion with a renal clearance of $4 \mathrm{~mL} / \mathrm{min} / \mathrm{kg}$. active tubular secretion with a renal clearance of $4 \mathrm{~mL} / \mathrm{min} / \mathrm{kg}$. clearance is thus reduced in patients with impaired renal function (See PRECAUTIONS and DOSAGE AND ADMINISTRATION).
Special Populations: Elderly: Pharmacokinetics of levetiracetam were evaluated in 16 elderly patients, ranging in age from $61-88$ years, with clearance ranging from 30 to $74 \mathrm{~mL} / \mathrm{min}$. Following oral administration of $500 \mathrm{mg}$ bid for 10 days, total body clearance decreased by $38 \%$ and the half-life was increased about $40 \%$ ( 10 to 11 hours) when compared to healthy adults. This is most likely due to the decrease in renal function in these subjects. Pediatrics (6 to 12 years): Pharmacokinetics of levetiracetam were evaluated in 24 pediatric patients (age 6-12 years) after a single dose. The apparent clearance patients (age 6-12 years) after a single dose. The apparent clearance higher than in epileptic adults. Cender: Levetiracetam $C_{\max }$ and AUC were $20 \%$ higher in women $(n=11)$ compared to men $(n=12)$. However, clearances adjusted for body weight were comparable. Race: Formal pharmacokinetic studies of the effects of race have not been conducted. Because levetiracetam is primarily renally excreted and there are no known important racial differences in creatinine clearance, signific

Renal Impairment: Single dose pharmacokinetics were performed in 20 subjects with renal impairment $\left(n=7 \mathrm{mild} / \mathrm{Cl}_{\mathrm{cr}}\right.$ of $50-79 \mathrm{~mL} / \mathrm{min}$ $n=8$ moderate $/ \mathrm{CL}_{c r}$ of $30-49 \mathrm{~mL} / \mathrm{min} ; n=5$ severe $/ \mathrm{CL}_{c}<30 \mathrm{~mL} / \mathrm{min}$ ). and $n=11$ matching healthy volunteers. Clearance of levetiracetam is correlated with creatinine clearance and levetiracetam pharmacokinetics following repeat administration were well pharmacokinetics following repeat administration were well parent drug levetiracetam is reduced in patients with impaired renal function by approximately $40 \%$ in the mild group. $50 \%$ in the moderate group, and $60 \%$ in the severe renal impairment group. For moderate group, and $60 \%$ in the severe renal impairment group. For the primary metabolite ucb $\mathbf{L 0 5 7}$, the decrease in clearance values
from baseline was greater than that seen for the parent drug in all subject groups.

In anuric (end stage renal disease) patients, the apparent body clearance was approximately $30 \%$ compared to that of normal subjects. Approximately $50 \%$ of the pool of levetiracetam in the body is removed during a standard 4-hour hemodialysis procedure. Dosage should be reduced in patients with impaired renal function receiving levetiracetam, and supplemental doses should be given to patients after dialysis (see PRECAUTIONS and DOSAGE AND patients after dialy
ADMINISTRATION)

Hepatic Impairment: A single-dose pharmacokinetic study was performed in 16 subjects with hepatic impairment $(n=5$ mild/ChildPugh Grade $A ; n=6$ moderate/Crade $B ; n=5$ severe/Grade $C$ vs 5 healthy controls). For the mild and moderate subgroups neither mean nor individual pharmacokinetic values were clinically different from those of controls. In patients with severe hepatic impairment, mean apparent body clearance was $50 \%$ that of normal subjects. with decreased renal clearance accounting for most of the decrease. Patients with severe hepatic impairment thus require a reduced dosage of Keppra ${ }^{\circ}$ (See PRECAUTIONS and DOSAGE AND ADMINISTRATION)

\section{NDICATIONS AND CUINICAL USE}

Keppra (levetiracetam) is indicated as adjunctive therapy in the management of patients with epil
controlled by conventional therapy

\section{CONTRAINDICATIONS}

This product should not be administered to patients who have previously exhibited hypersensitivity to levetiracetam or any of the inactive ingredients in Keppraø (levetiracetam) tablets.

\section{WARNINGS}

Central Nervous System Adverse Events

Keppras (levetiracetam) use is associated with the occurrence of central nervous system (CNS) adverse events; the most significant of these can be classified into the following categories: 1) somnolence
and fatigue, 2) behavioral/psychiatric symptoms and 3) coordination and fatigue,

There was no clear dose response relationship for any of the three categories of CNS adverse events, within the recommended dose range of up to $3000 \mathrm{mg} /$ day. Somnolence/asthenia and coordination difficulties occurred most frequently within the first four weeks of treatment and usually resolved while patients remained on treatment. In the case of behavioral/psychiatric symptoms (including such adverse events as aggression, agitation, anger, anxiety, emotional such adverse events as aggression, agitation, anger, anxiety, emotional lability, hostility, irritability), approximately half of the patients
reported these events within the first four weeks, with the remaining reported these events within the first four weeks, with the remaining
events occurring throughout the duration of the trials. See also events occurring throughout the duration of the trials.
PRECAUTIONS, Central Nervous System Adverse Events.

\section{Withdrawal of Anti-Epileptic Drugs}

As with all antiepileptic drugs, Keppra should be withdrawn gradually to minimize the potential of increased seizure frequency.

\section{PRECAUTIONS}

General

Hematological Abnormalities: Minor but statistically significant decreases compared to placebo were seen in total mean RBC count. mean hemoglobin, and mean hematocrit in Kepprats-treated patients in controlled trials. For hemoglobin values, the percentage of Keppra or placebo treated patients with possibly clinically significant abnormalities were less than $0.5 \%$ each. For hematocrit values, a total of $5.1 \%$ of Keppra treated versus $3.2 \%$ of placebo patients had at
least one possibly significant decrease in hematocrit ( $\leq 37 \%$ in males least one possibly signific

For white blood cells (WBC), $2.9 \%$ of treated versus $2.3 \%$ of placebo patients had at least one possibly clinically significant decrease in WBC count $\left(\leq 2.8 \times 10^{9} / \mathrm{L}\right)$, while $2.6 \%$ of treated vs. $1.7 \%$ of placebo patients had at least one possibly significant decrease in neutrophil count $\left(\leq 1.0 \times 10^{9} /\right)$. Of the Keppra ${ }^{\infty}$-treated patients with a low neutrophil count, all but one rose towards or reached baseline with continued treatment.
secondary to low neutrophil counts.

Central Nervous System Adverse Events (See WARNINGS): Keppra" (levetiracetam) use is associated with the occurrence of central nervous system (CNS) adverse events; the most significant of these can be classified into the following categories: 1) somnolence and fatigue, 2) behavioral/psychiatric symptoms and 3) coordination

The following CNS adverse events were observed in controlled clinical trials.

Table 1:

Total Combined incidence Rate for Each of the Three Categories of CNS Adverse Events in Placebo-controlled Add-on Clinical Trials.

\begin{tabular}{|lcc|}
\hline $\begin{array}{l}\text { Category of CNS } \\
\text { adverse event }\end{array}$ & $\begin{array}{c}\text { Keppra } \Phi^{*}+ \\
\text { AED therapy } \\
(n=672)\end{array}$ & $\begin{array}{c}\text { Placebo + } \\
\text { AED therapy } \\
(n=351)\end{array}$ \\
\hline $\begin{array}{l}\text { Somnolence and fatigue } \\
\text { Somnolence } \\
\quad \text { Asthenia }\end{array}$ & $15 \%$ & $10 \%$ \\
\hline $\begin{array}{l}\text { Behavioral/psychiatric symptoms } \\
\text { Nonpsychotic' } \\
\text { Psychotic }\end{array}$ & $14 \%$ & $10 \%$ \\
\hline Coordination difficulties $^{3}$ & $14 \%$ & $6 \%$ \\
\hline
\end{tabular}

Reflects Kepprat doses of $1000 \mathrm{mg}, 2000 \mathrm{mg}, 3000 \mathrm{mg}$, and $4000 \mathrm{mg}$ per day.

"Non-psychotic behavioral/psychiatric symptoms" encompasses the following terms: agitation, antisocial reaction, anxiety, apathy, depersonalization, depression, emotional lability, euphoria,
neurosis, personality disorder and suicide attempt.

passes the followin terms: hallucinations, paranoid reaction, psychosis and psychotic depression

"Coordination difficulties" enco See ADVERSE EVENTS, Table 2, for incidence rate of individual AES contained within the categories.

Behavioral/psychiatric symptoms (including agitation, emotional lability, hostility, anxiety, etc.) have been reported approximately equally in patients with and without a psychiatric history.

There was no clear dose response relationship for any of the three categories of CNS adverse events, within the recommended dose range of up to $3000 \mathrm{mg} / \mathrm{day}$. In a controlled study including a dose
of $4000 \mathrm{mg}$, administered without titration, the incidence rate of of $4000 \mathrm{mg}$, administered without titration, the incidence rate of somnolence during the first four weeks of treatment for patients receiving the high dose
receiving $2000 \mathrm{mg} /$ day.

\section{Special Populations}

Patients with Renal Impairment: Renal excretion of unchanged drug accounts for approximately $66 \%$ of administered levetiracetam dose. Consistent with this, pharmacokinetic studies in renallympaired patients indicate that apparent clearance is significantly reduced in subjects with renal impairment (see ACTION AND CUINICAL PHARMACOLOCY, Special Populations).

In patients with renal impairment Keppra dosage should be appropriately reduced. Patients with end stage renal disease, i.e. those undergoing dialysis, should be given supplem

Pregnancy and Nursing: There are no adequate and well-controlled studies on the use of Keppra in pregnant women. Levetiracetam and/or its metabolites cross the placental barrier in animal species. In reproductive toxicity studies in rats and rabbits, levetiracetam induced developmental toxicity at exposure levels similar to or greater than the human exposure. There was evidence of increased skeletal variations/minor anomalies, retarded growth, embryonic death, and increased pup mortality. In the rat, fetal abnormalities occurred in the absence of overt maternal toxicity. The systemic exposure at the observed no effect level in the rabbit was about 4 to 5 times the human exposure. The potential risk for humans is unknown. Keppra should not be used during pregnancy unless untential benefits to mother and fetus are considered to outweigh potential risks to both. Discontinuation of antiepileptic treatments may result in disease worsening, which can be harmful to the

Pregnancy Exposure Registry: To facilitate monitoring of fetal outcomes of pregnant women exposed to Keppras. physicians should encourage patients to register, before fetal outcome is known (e.g., ultrasound, results of amniocentesis, etc.), in the Antiepileptic Drug Pregnancy Registry by calling (888) 233-2334 (toll free). Nursing Mothers: Levetiracetam is excreted in breast milk. Therefore, there is a potential for serious adverse reactions from Keppras in nursing infants. Recommendations regarding nursing and epilepsy medication should take into account the importance of the drug to the mother, and the as yet uncharacterized risks to the infant. necessary prior risk-benefit judgement, regarding pregnancy and epilepsy medication.

Use in Pediatric Patients: Safety and efficacy in patients below the age of 18 have not been established.

Use in the Elderly: Renal function can be decreased in the elderly and levetiracetam is known to be substantially excreted by the kidney. the risk of adverse reactions to the drug may be greater in patients with impaired renal function. A pharmacokinetic study in 16 elderly subjects (age 61-88 years) showed a decrease in clearance by about $40 \%$ with oral administration of both single dose and 10 days of multiple twice-daily dosing. This decrease is most likely due to the expected decrease in renal function in these elderly subjects. Care should therefore be taken in dose selectio

There were insufficient numbers of elderly patients in controlled trials of epilepsy to adequately assess the efficacy or safety of Keppra in these patients. Nine of 672 patients treated with Keppra were 65 or over.

\section{Drug Interactions}

In Vitro Studies on Metabolic Interaction Potential In vitro, levetiracetam and its primary metabolite have been shown not to inhibit the major human liver cytochrome P450 isoforms (CYP3A4, 2A6, 2C8/9/10, 2C19, 2D6, $2 E 1$ and $1 \mathrm{~A} 2$ ), glucuronyl transferase (paracetamol UGT, i.e. UGT1A6, ethinyl estradiol UCT, i.e.UGT1A1, and $p$-nitrophenol UGT, i.e.UGT [p16.2]) and epoxide hydrolase glucuronidation of valproic acid. In human hepatocytes in culture, levetiracetam did not cause enzyme induction.

Levetiracetam circulates largely unbound ( $<10 \%$ bound) to plasma 


\section{Clinical Pharmacokinetic Data}

Other Antiepileptic Drugs (AEDs): Potential drug interactions between Keppra and other AEDs (phenytoin, carbamazepine, valproic acid, phenobarbital, lamotrigine, gabapentin and primidone) were assessed by evaluating the serum concentrations of levetiracetam and these AEDs during placebo-controlled clinical studies. These data suggest that levetiracetam may not significantly influence the plasma concentrations of these other AEDs, and that the other AEDs may not significantly influence the plasma concentrations of levetiracetam

For two of these AEDs - phenytoin and valproate - formal pharmacokinetic interaction studies with Keppra ${ }^{\otimes}$ were performed $\mathrm{Keppra}^{\otimes}$ was CO-administered with either phenytoin or valproate at doses of $3000 \mathrm{mg} /$ day and $1000 \mathrm{mg} /$ day respectively. No clinically significant interactions were observed.

Other Drug Interactions

Oral Contraceptives: A pharmacokinetic clinical interaction study has been performed in healthy subjects between the oral contraceptive containing $0.03 \mathrm{mg}$ ethinyl estradiol and $0.15 \mathrm{mg}$ levonorgesterol and the lowest therapeutic dose of Keppra ${ }^{\circledR}(500 \mathrm{mg}$ bid). No clinically significant pharmacokinetic interactions were observed.

However, pharmacokinetic interaction studies using Keppra as adjunctive therapy and covering the recommended dosage range, have not been conducted. Therefore, physicians should advise their female patients to be alert to any irregular vaginal bleeding or spotting and to immediately report to them any occurrences.

Digoxin: Keppra ${ }^{\boxplus}(1000 \mathrm{mg}$ bid) did not influence the pharmacokinetics and pharmacodynamics (ECG) of digoxin given as a $0.25 \mathrm{mg}$ dose every day. Coadministration of digoxin did not influence the pharmacokinetics of levetiracetam.

Warfarin: Keppra ${ }^{\oplus}(1000 \mathrm{mg}$ bid) did not influence the pharmacokinetics of R and $S$ warfarin ( $2.5 \mathrm{mg}, 5 \mathrm{mg}$, or $7.5 \mathrm{mg}$ daily) Prothrombin time was not affected by levetiracetam. Coadministration of warfarin did not affect the pharmacokinetics of levetiracetam.

Probenecid: Probenecid, a renal tubular secretion blocking agent admiristered at a dose of $500 \mathrm{mg}$ four times a day, did not change the pharmacokinetics of levetiracetam $1000 \mathrm{mg}$ bid. $C_{\mathrm{scmax}}$ of the the pharmacokinetics of levetiracetam $1000 \mathrm{mg}$ bid. $C_{5 s m a x}$ of the probenecid and the renal clearance of the metabolite ucb L057 was decreased by $60 \%$; this alteration is likely related to competitive inhibition of tubular secretion of ucb L057. The effect of Kepprat on probenecid was not studied

\section{ADVERSE EVENTS}

Commonly Observed

In well-controlled clinical studies, the most frequently reported adverse events associated with the use of Keppra in combination with other AEDs, not seen at an equivalent frequency amon placebo-treated patients, were somnolence, asthenia, dizziness and infection of the most frequently reported adverse events, asthenia somnolence and dizziness appeared to occur predominantly during the first four weeks of treatment with Keppra

\section{Incidence of AEs in Controlled Clinical Trials}

Table 2

Incidence (\%) of Treatment-emergent Adverse Events in Placebocontrolled, Add-on Studies by Body System. (Adverse Events

Occurred in at least $1 \%$ of Keppra-treated Patients and Occurred

Moccurred in at least $1 \%$ of Keppra ${ }^{-}$-treated Patiently than Placebo-treated Patients.)

More Frequently than Placebo-treated
(Studies N051, N052, N132 and N138)

\begin{tabular}{|l|c|c|}
\hline $\begin{array}{l}\text { Body system/ } \\
\text { adverse event }\end{array}$ & $\begin{array}{c}\text { Keppra }{ }^{+}+ \\
\text {AED therapy } \\
(n=672)(\%)\end{array}$ & $\begin{array}{c}\text { Placebo }+ \\
\text { AED therapy } \\
(\mathrm{n}=351)(\%)\end{array}$ \\
\hline Body as a whole & 14 & 10 \\
Asthenia & 13 & 7 \\
\hline Infection" & 2 & 1 \\
\hline Digestive system & & \\
Tooth disorders & & 1 \\
\hline Hemic and & 2 & \\
lymphatic system & & 0 \\
Ecchymosis & 2 & 1 \\
\hline Nervous system & 2 & 1 \\
Amnesia & 3 & 4 \\
Anxiety & 4 & 0 \\
Ataxia & 9 & 1 \\
Depression & 2 & 2 \\
Dizziness & 2 & 0 \\
Emotional lability & 4 & 10 \\
Hostility & 1 & 1 \\
Nervousness & 15 & 1 \\
Personality disorders & 2 & \\
Somnolence & 3 & 3 \\
Thinking abnormal & & 1 \\
Vertigo & & \\
\hline Respiratory system & & \\
Pharyngitis & & \\
Rhinitis & & \\
Sinusitis & & \\
\hline & & \\
\hline
\end{tabular}
"In levetiracetam-treated patients, the majority of "infection" events
$(93 \%)$ were coded to reported terms of "common cold" or "infection (93\%) were coded
upper respiratory".

\section{Additional Events Observed in Placebo Controlled Trials}

Lack of Dose-related Incidence within Therapeutic Range: Based on the data from the controlled clinical trials, there was no evidence of dose relationship within the recommended dose range of 1000 to $3000 \mathrm{mg} /$ day.

Discontinuation or Dose Reduction in Well-controlled Clinical Studies: in weil-controlled clinical studies, $14.3 \%$ of patients receiving $\mathrm{Keppra}^{\oplus}$ and $11.7 \%$ receiving placebo either discontinued or had a dose reduction as a result of an adverse event. The adverse events most commonly associated ( $>1 \%$ ) with discontinuation or dose reduction in either treatment group are presented in Table 3.
Table 3:

Adverse Events Most Commonly Associated with Discontinuation or Dose Reduction in Placebo-controlled Studies in Patients with Epilepsy

\begin{tabular}{|lcc|}
\hline & $\begin{array}{l}\text { Keppra } \\
(\mathbf{n = 6 7 2 )}\end{array}$ & $\begin{array}{c}\text { Placebo } \\
(\mathbf{n = 3 5 1 )}\end{array}$ \\
\hline Asthenia & $9(1.3 \%)$ & $3(0.9 \%)$ \\
\hline Headache & $8(1.2 \%)$ & $2(0.6 \%)$ \\
\hline Convulsion & $16(2.4 \%)$ & $10(2.8 \%)$ \\
\hline Dizziness & $11(1.6 \%)$ & 0 \\
\hline Somnolence & $31(4.6 \%)$ & $6(1.7 \%)$ \\
\hline Rash & 0 & $5(1.4 \%)$ \\
\hline
\end{tabular}

The overall adverse experience profile of Keppra was simila between females and males. There are insufficient data to support a statement regarding the distribution of adverse experience reports by age and race.

\section{Post-marketing Experience}

In post-marketing experience, nervous system and psychiatric disorders have most frequently been reported. In addition to adverse reactions during clinical studies, and listed above, the following adverse reactions have been reported in post-marketing experience. Data are insufficient to support an estimate of their incidence in the population to be treated.

Blood and lymphatic disorders: leukopenia, neutropenia, pancytopenia, thrombocytopenia.

\section{SYMPTOMS AND TREATMENT OF OVERDOSE}

Symptoms

The highest reported Keppra overdose is approximately 10 times the therapeutic dose. In the majority of overdose cases, multiple drugs were involved. Somnolence, agitation, aggression, depressed level of consciousness, respiratory depression, and coma were observed with Keppra overdoses. The minimal lethal oral dose in rodents is at least 233 times the maximum clinically studied dose.

\section{Treatment}

There is no antidote for overdose with Keppra. treatment is symptomatic and may include hemodialysis. If indicated, elimination of unabsorbed drug should be attempted by emesis or gastric lavage usual precautions should be observed to maintain airway. General supportive care of the patient is indicated including monitoring of vital signs and observation of the clinical status of the patient. Standard hemodialysis procedures result in significant removal of levetiracetam (approximately $50 \%$ in 4 hours) and should be considered in cases of overdose. Although hemodialysis has not been performed in the few known cases of overdose, it may be ind performed in the few known cases of overdose, it may be indicated
by the patient's clinical state or in patients with significant renat impairment.

General

\section{DOSAGE AND ADMINISTRATION}

Renal excretion of unchanged drug accounts for approximately $66 \%$ of administered levetiracetam dose. Consistent with this, reduced doses are recommended for patients with renal impairment.

Keppra ${ }^{\oplus}$ is given orally with or without food.

Adults

Treatment should be initiated at a dose of $1000 \mathrm{mg} /$ day, given as twice daily dosing ( $500 \mathrm{mg}$ bid). Depending on clinical response and tolerability, the daily dose may be increased every two weeks by increments of $1000 \mathrm{mg}$, to a maximum recommended daily dose of $3000 \mathrm{mg}$

In ciirical trials, daily doses of $1000 \mathrm{mg}, 2000 \mathrm{mg}$, and $3000 \mathrm{mg}$, given as twice a day dosing, were shown to be effective, Although there was a tendency toward statistically significant increase in response with increased dose has statistically significant increase in response with increased dose has not been shown. There are limited safety data from controlied clinical
trials at doses higher than $3000 \mathrm{mg} /$ day (approximately 40 patients) trials at doses higher than $3000 \mathrm{mg} /$ day (app
therefore these doses are not recommended.

Patients with Impaired Renal Function

Keppra ${ }^{\oplus}$ dosage should be reduced in patients with impaired renal function (see Table 4 below). Patients with end stage renal disease should receive supplemental doses following dialysis. To use this dosing table, an estimate of the patient's $C L_{c}$ in $\mathrm{mL} / \mathrm{min}$ is needed $\mathrm{CL}_{\mathrm{c}}$ in $\mathrm{mL} / \mathrm{min}$ may be estimated from serum creatinine $(\mathrm{mg} / \mathrm{dL})$ $\mathrm{CL}_{\mathrm{cr}}$ in $\mathrm{mL} /$ min may be estimated from $\mathrm{ser}$
determination using the following formula:

$\mathrm{CL}_{\mathrm{cr}}=\frac{[140 \text {-age (years) }] \times \text { weight }(\mathrm{kg})}{72 \times \text { serum creatinine }(\mathrm{mg} / \mathrm{dL})}(\times 0.85$ for female patients $)$

Table 4:

Dosing Adjustment for Patients with Impaired Renal Function

\begin{tabular}{|lll|}
\hline Group & $\begin{array}{l}\text { Creatinine } \\
\text { clearance } \\
\text { (mL/min) }\end{array}$ & $\begin{array}{l}\text { Dosage and } \\
\text { frequency }\end{array}$ \\
\hline Normal & $\geq 80$ & 500 to $1500 \mathrm{mg}$ twice daily \\
Mild & $50-79$ & 500 to $1000 \mathrm{mg}$ twice daily \\
Moderate & $30-49$ & 250 to $750 \mathrm{mg}$ twice daily \\
$\begin{array}{l}\text { Severe* } \\
\begin{array}{l}\text { End-stage renal } \\
\text { disease patients } \\
\text { undergoing dialysis' }\end{array}\end{array}$ & $<30$ & 250 to $500 \mathrm{mg}$ twice daily \\
\hline
\end{tabular}

t Following dialysis, a 250 to $500 \mathrm{mg}$ supplemental dose is recommended. "or according to best clinical judgement

Patients with Impaired Hepatic Function

No dose adjustment is needed in patients with mild-to-moderate hepatic impairment. in patients with severe hepatic impairment, the creatinine clearance may underestimate the renal insufficiency. Therefore a $50 \%$ reduction of the daily maintenance dose is recommended when the creatinine clearance is $<70 \mathrm{~mL} / \mathrm{min}$. Elderly Patients

Dose selection and titration should proceed cautiously in elderly patients, as renal function decreases with age.
PHARMACEUTICAL INFORMATION

Drug Substance

Chemical Name: (-)-(S)- $\alpha$-ethyl-2-oxo-1-pyrrolidine acetarnide Structural formula:<smiles>CC[C@@H](C(N)=O)N1CCCC1=O</smiles>

Molecular Formula: $\mathrm{C}_{8} \mathrm{H}_{14} \mathrm{~N}_{2} \mathrm{O}_{2}$

Molecular Weight: 170.21

Physical Form: A white to off-white crystalline powder with a faint odor and a bitter taste.

Solubility: It is very soluble in water $(104.0 \mathrm{~g} / 100 \mathrm{~mL})$. It is freely soluble in chloroform $(65.3 \mathrm{~g} / 100 \mathrm{~mL})$ and in methanol $(53.6 \mathrm{~g} / 100 \mathrm{~mL})$, soluble in ethanol $(16.5 \mathrm{~g} / 100 \mathrm{~mL})$, sparingly soluble in acetonitrile $(5.7 \mathrm{~g} / 100 \mathrm{~mL})$ and practically insoluble in $n$-hexane.

$\mathrm{pKa}$ and $\mathrm{pH}$ values: The $\mathrm{pKa}$ of levetiracetam is $<-2$ and cannot be determined with accuracy due to the chemical instability of the protonated form

The protonation of ucb $\mathrm{L} 059$ starts at $\mathrm{H}_{0}$ values between -1 and -2 . Partition Co-efficient: $\Delta \log P\left(\log P_{\text {octanol }}-\log \mathrm{P}_{\text {cyclohexane }}\right)$ was calculated at $\mathrm{pH} 7.4$ using phosphate buffered saline and at $\mathrm{pH} 1.0$ using KCl/HCl. The $\Delta \log \mathrm{P}$ at $\mathrm{pH} 7.4$ is 3.65 and at $\mathrm{pH} 7.0$ is 3.10 . Melting Range: $115-119^{\circ} \mathrm{C}$

Composition: Keppra ${ }^{\mathbb{E}}$ tablets contain the labeled amount of levetiracetam. Inactive ingredients include colloidal silicon dioxide, corn starch, hydroxypropyl methylcellulose, magnesium stearate, polyethylene glycol 4000 , povidone, talc, titanium dioxide and coloring agents.

The individual tablets contain the following coloring agents:

$250 \mathrm{mg}$ tablets: FD\&C Blue No. 2

$500 \mathrm{mg}$ tablets: FD\&C Blue No. 2 and yellow iron oxide.

$750 \mathrm{mg}$ tablets: FD\&C Btue No. 2, FD\&C Yeliow No. 6 and red iron oxide.

Stability and Storage Recommendations

Store between $15-30^{\circ} \mathrm{C}\left(59-86^{\circ} \mathrm{F}\right)$. AVAILABILITY OF DOSAGE FORMS

Keppra ${ }^{\oplus}$ (levetiracetam) tablets, $250 \mathrm{mg}$ are blue, oblong-shaped film-coated tablets debossed with "ucb" and "250" on one side. They are supplied in bottles of 120 tablets.

Keppra ${ }^{\circledast}$ (levetiracetam) tablets, $500 \mathrm{mg}$ are yellow, oblong-shaped, film-coated tablets debossed with "ucb" and " 500 " on one side. They are supplied in bottles of 120 tablets.

Keppra (levetiracetam) tablets, $750 \mathrm{mg}$ are orange, oblongshaped, film-coated tablets debossed with "ucb" and "750" on one side. They are supplied in bottles of 120 tablets.

For more information, please refer to the complete Keppra ${ }^{\oplus}$ Product Monograph.

References: 1. Cereghino J], Biton V, Abou-Khatil B, et al. Levetiracetam for partial seizures: results of a double-blind, randomized clinical trial. Neurology 2000;55:236-4. 2. Keppra Product Monograph. UCB Pharma, Inc.

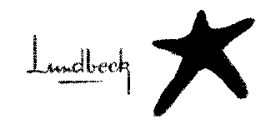

- Keppra is a registered trademark of UCB SA.

Keppra is distributed by Lundbeck Canada Inc., 413 St-Jacques St. West, Suite FB-230, Montreal, Quebec H2Y 1N9 
08841856 (Rev. Jully 2003)

Immune Globulin Intravenous (Human), 10\%

\section{GAMUNEX ${ }^{\mathrm{TM}}$}

Manufactured by Chromatography

PASSIVE IMMUNIZING AGENT

ACTION AND CLINICAL PHARMACOLOGY

General

GAMUNEX' \{Immune Globulin Intravenous [Human], 10\%) manufactured by a patented chromatography process is a ready-touse sterlle solution of human immune globulin protein for intrw

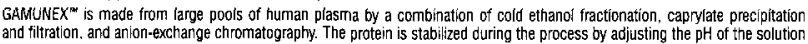
10 4.0-4.5. Isotonicity is achieved by the addition of glycine

The capacity of the manufacturing process to remove and/or inactivate enveloped and non-enveloped viruses has been validated by laboratory spiking studies on a scaled down processs model using relevant and model viruses. In the GAMUNNEX manufac-
turing process, virus inactivation and/or removal is achieved by way of capnlate precipitation and cloth filtration, caprylate furng process, virus inactivation and/or removal is achieved by way of caprylate precipitation and cloth filtration, caprylate
incubation, column chromatography, and final container low oH incubation, evaluated Independently and in combination to incubation, cclumn chromatography, and tinal container low $\mathrm{pH}$ incubation, evaluated ndependently and in combination to
identify those steps which are mechanistically distinct. Each steo was verified to provide robust virus reduction across the
production range tor key operating parameters. (See PHARMACEUTICAL INFORMAT ION). Furthermore, data derived from prion spiking studies hweve shown that the GAMUNEX'" process has the potential to remove animal
model prions ${ }^{12}$ (See PHARMACEUTICAL INFORMATION). The buffering capacity of GAMUNEX" is $35.0 \mathrm{mEg} / \mathrm{L}$ (0.35 mEq/g proteinj. A dose of $1000 \mathrm{mg} / \mathrm{kg}$ body weight therefore
represents an acid load of $0.35 \mathrm{mEg} / \mathrm{kg}$ body weight. The total buffering capacity of whole blood in a normal individual is
$45-50 \mathrm{mEg} / \mathrm{L}$ of blood or $3.6 \mathrm{mEg} / \mathrm{kg}$ body weight. 3 Thus, the acid load delivered with a dose of $1000 \mathrm{mg} / \mathrm{kg}$ of GAMUNEX" $45-50 \mathrm{mEg} / \mathrm{L}$ of blood, or $3.6 \mathrm{mEq} / \mathrm{kg}$ body weight ${ }^{3}$ Thus, the acid load delivered with a dose of $1000 \mathrm{mg} / \mathrm{kg}$ of GAMUNEX
would be neutralized by the buttering caaacity of whote blood alone, even if the dose was infused instantaneousy. Gycine would be neutralized by the butfering capacity of whote blood alane, even If the dose was infused instantaneously. Glycine
caminoacetic acidl is a nonessential amino acid normally present in the body. Glycine is a major ingredient in amino acid solutions

In patients with limited or compromised acid-base compensatory mechanisms, and in patients in whom there is a:ready an that may occur.

The pharmacokinetic parameters AUC and $C_{\text {max }}$ of GAMUNEX'm in a randornized clinical trial involving Primary Imrnunodeficiency curve follows a biphasic slope with a distribution phase of about 5 days characterized by a fall in serum lgG levels to abcut $65.75 \%$ of the peak levels achieved immediately post-infusion. This phase is followed by the elimination phase with a half-life of Primary Humoral Immunodeficiency

Immune Globulin Intravenous (Human), 10\% suppiles a broad spectrum of opsonic and neutralizing IgG antibodies against bacteria. viruses or their taxins, that have been demonstrated to be effective in the prevertion or attenuation of lethal infections
in animal models. Immune Globulin Intravenous (Human). $10 \%$ has proven to be effective in preventing infections in patients equivalence to GAMIMUNE ${ }^{\circ}$ N. $10 \%$ (Immune Globulin Intravenous [Hurman], $10 \%$ - Solvent/ Detergent Treated).

Idiopathic Thrombocytopenic Purpura The mechanism of action of high doses of immunoglobulins in the treatment of Idiopathic Thrombocytopenic Purpura (ITP) has
rot been fuly elucidated. It is postulated that the mechanisms of action may be the FC-receptor biockade of phagocytes as well
as the down regulation of auto-reactive B-cells by antididiotypic antibocies proviced by human immune globulin.?-12 Allopeneic Bone Marrow Trensplantallion

The mechanism of action of Immune Globulin Intravenous (Human), $10 \%$ in protecting irnmure-cornpromised patients with
Allogenic Bone Marrow Transplantation (BMT) from serious bacterial infections is simitar to the anti-infective mechanism of action in PID. 21 The immunomodilatory mechanism of action of Immuna Globulin Intravenous (Human), $10 \%$ in suppressing acute graft versus nost reaction in patients with immune cells involving Fab and Gc tunctions of the immunoglobulin molecules is similar to Podiatric HIV Inteclion

Children with HIV infections, particularly when acquired through vertical transmission, are prone to recurrent serious bacterial infections. Types of infection se日n in these children are simllar to those with primary hypogammaglobalinemia The replacement of opsonic and neutralizing ggG antibodies has been shown to be effective in pediatric HIV infections. The anti-infective
mechansm of action of Immune Globulin Intravenous (Human), $10 \%$ in the Pediatric $\mathrm{HV}$ is comparable to that in PID. INDICATIONS AND USAGE

GAMUNEX'th (IImmune Globulin Intravenous [Human] 10\%) is indicated in:

Primary Humoral Immunodeflciency

GAMUNEX" is indicated as replacement therapy of primary humoral immunodeficiency states in which severe impairment of antibody forming capacity has been shown, such as congenital agammaglobulinemia, common variable immunodeficiency, In a double-blind, randomized, parallel group clinical trial in patients with primary humoral immunodeficiencies GAMUNEX' was demonstrated to be at least as efficacious as GAMMMUNEE N $10 \%$ in the prevention of infectlons during a nine month treatment

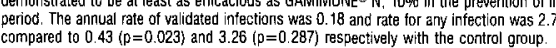

dilopathic Thrombacytopenic Purpura

GAMUNEX' is indicated in Idiopathic Thrombocytopenic Purpura (TP) to rapidly raise platelet counts to prevent bleeding or to allow a patient with ITP to undergo surgery.

A double-blind, randomized, paralel group clinical trial with 97 acute or chronic ITP patients (adults and children), GAMUNEX ${ }^{\text {w }}$

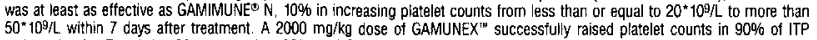
$50^{*} 109 \%$ within 7 days atter treatment. A $2000 \mathrm{mg} / \mathrm{kg}$ dose of GAMUNEX"'s successtuily raised platelet counts in $90 \%$ of ITP
patients by day 7 and day 23 compared to $83 \%$ and $86 \%$ respectively, in the control group. A sustained 7 day response was

Allogeneic Bone Marrow Transpiantation

GAMUNEX"' is indicated for the reduction of septicemia and other infections, interstitial pneumonia and acute graft versus host Shortly before, and for varying times atter bone marrow transplantation, patients are immunosuppressed. The benefit of Immune Globulin intravenous (Human] in these patients during the recovery period is simitar to that of replacement therapy in PiD. The
utility of Immune Globulin Intravenous (Human) in BMT had been confirmed by long-term experience and in peer-reviewed pubilished reports. 1 .

Graft-versus-host-disease (GivHD) is a frequent complication of BMT. Immune Globulin Intravenous (Humani) has been Pedlatric HIV Infectlon

GAMUNEX" is indicated for the reduction of recurrent serious bacterial infections in those children who do not respond to or cannot tolerate antiretroviral combination therapy. Children with HV infections, particularly when accuired through vertical
transmission, are prone to recurrent serious bacterial intections, although they have apparently normal or supranormal lgG levels.

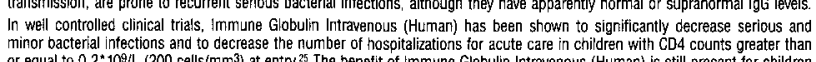
or equal to .22 who CONTRAINDICATIONS

GAMUNEX'm (Immune Giobulin Intravenous [Human], 10\%) is contraindicated in individuals with known anaphylactic or severe

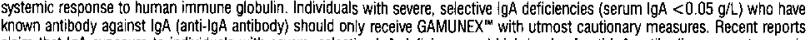

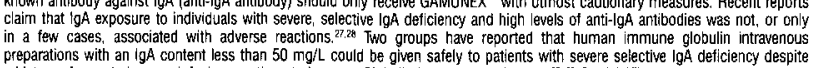

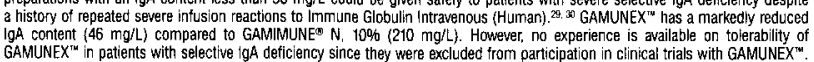
WARNINGS

Immuna Globulin Intravenous (Human) products have been reported to be associated with renal dystunction, acute renal tailure, oamofitc nephrosis and daath." Patients predlsposed to acute renal tailure include patients with any degree of preoxisting renal insuifliciency, dtabattes mollitus, ape orgater than 65, volume deplation, sepsis, paraproteinemia, of patients

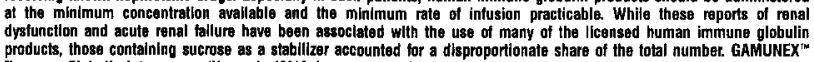
(Immune Globullin Intravenous (Human), 10\%/] does not contain sucrose.

See PRECAUTIONS and DOSAGE AND AOMINISTRAT:ON sections for important information intended to reduce the risk of acute

GAMUNEX'“ is mada from human plasma. Products made from human plasma may contain Intectious agents, such as viruses, that can cause disease. The risk that such products will transmit an infectious agent has been reduced by screening
plasma donors tor prior exposure to certain viruses, by testing for the presence of certain current virus infections, and by

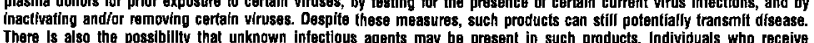

infusions of blood ar plasma products may develop signs and/or symptoms of some viral infections, particularly hepatitis C All Infections thought by a physiclan possibly to have been transmitted by this product should be reported by the phyziclan or other healtheare provider to Bayer Inc. [1-800-265.73822]. The phystcian stout
product with the patient, bettore prescribing or administering it to the patient.

GAMUNEX" should be administered intravenously only. On rare occasions, treatment with an immune globulin preparation may cause a precipitous fall in blood pressure and a clinical picture of anaptylaxis, evern when the patient is not known to be sensitive to immune globulin preparations. Epinephrine should be available for the treatment of an acute anaphylactic reaction. PRECAUTIONS

Any vial that has been punctured should be used promptly. Partially used vials should be discarded. Visually inspect each bottle Detore use. Do not use if turbid. If the solution has been frozen, it must not be used.

An aseptic meningitis syndrome (AMS) has been reported to occur infrequently in association with Immune Globulin Intravenous (Human) treatment. The syndrome usually begins within severa hours to two days following Immune Globutin Intraventous
(Human) treatment. It is characterized by symptoms and signs including severe headache, nuchal rigidity, drowsiness, fever

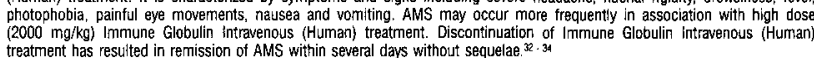

Periodic monitoring of renal function and urine output is particularly important in patients judged to have a potential increased risk for developing acute renal tailure. Renal tunction, including measurement of blood urea nitrogen (BUN)/serum creatinine orates, discontinuation of the product should be considered. For patients judged to be at risk for developing renal dystunction it may be prudent to reduce the amount of product infused per unit time by infusing GAMUNEX's [Human], $10 \%$ ) at a rate less than $8 \mathrm{mg} / \mathrm{kg} / \mathrm{min}(0.08 \mathrm{~mL} / \mathrm{kg} / \mathrm{min})$.

Assure that all patients are not volume depleted prior to the initiation of the infusion of Immune Globulin Intravenous

In some patients, administration of GAMUNEX't results in a transitory rise of passively transterred antibodles which may produce miseading serological findings such as positive direct anti-globulin and anti-HBc results in the absence of viral transmission. There is a possible association between thrombo-embolic (IE) events and administration of Immune Globulin Intraverous
(Human) (IGIV) products. Caution should be exercised in administration of IGIV in patients with coagulopathies, cardiovascular disease, thromboohilia, restricted mobility, and the elderty. The etiology of TE events related to IGIV therapy is not clear and may reflect IGIV dose and hyperosmoiality's, 45. GAMUNEX $X^{\text {tw }}$ is an is

Drug Interactions

Antibodies in GAMUNEX'* may interfere with the response to live viral vaccines such as measses, mumps and rubeila. Therefore, USE of SUCh vaccines should be deferred until appo
ADMINISTRATION for other relevant interactions).

Pregnancy

Animal reproduction studies have not been conducted with GAMUNEX'w. It is not known whether GAMUNEX'w can cause fetal harm when administered to a pregnant woman or can affect reproduction capacity. GAMUNEX"m should be given to a pregnant ADVERSE REACTIONS

General

Increases in creatinine and blood urea nitrogen (BUN) have been observed as soon as one to two days following infusion, predominantly with of er human immune globulin products, stablized with sucrose. Progression to ollguria and anuria requiring dialysis (Immune Globulin Intravenous [Human, 10\%) does not contain sucrose. Glycine, a natural amino acid, is used as a stabilizer. In

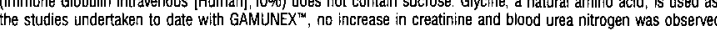

Although not all adverse efitects previously reported with intravenous and intramuscular immunoglobulin administration have been observed for GAMUNEX's, adverse effects may be expected to be similar to those reported with these produch
reactions may include anxiety, flushing, wheezing, abcominal cramps, myalgias, anthralgia, dizziness, and rash.

True anaphylactic reactions to GAMUNEX ${ }^{\text {ww }}$ may occur in recipients with documented prior histories of severe alergic reaction to intramusccular immunoglobulin, but some patients may tolerate cautiously administered intravenous immunoglobulin without
adverse effects. 3 Very rarely an a nath hylactoid reaction may occur in patients with no prior history of severe allergic reactions 10
either intramuscular or intravenous immunoglobulin.

Direct antiglobin tests (DAT or direct Coombs tests), which are carried out in some centers as a safety check prior to red blood may contain: low levels of anti Blood Groug A and B antibodies primarily of the lgG4 class. However, there was no evidence of hemolysis or significant clinical effect in association with positive DAT findings in clinical trials. ${ }^{5.537 .}-3$. In some patents in the clinical trial program, administration with GAMUNEX'"' res
and hemoglobin with no evidence of hemolysis or significart clinical outcorne.

Primary Humoral Immunodeficieney

Adverse events were monitored in three randomized clinical trials, Involving more than 200 primary humoral immunodeficiency three subsequent intusions on a 3 or 4 week infusion interval and were then crossed over to three infusions of the alternate

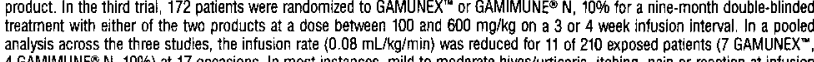
Gill site, anxiety or headache was the main reason for reduction in into mion In the pivotal clinical trial, the mast trequently recorded dnug related adverse events (z0.5\%) normalized per patient and Infusion are given in the table below:

\begin{tabular}{|c|c|c|}
\hline Drug Related Adwerse Events & GAMUNEX ${ }^{w}$ No. of Infusions: 825 & GAMMMUNE* $\mathrm{N}, 10 \%$ No. of infusions: 865 \\
\hline Cough increased & $14(1.7 \%)$ & $11(1.3 \%)$ \\
\hline Heacache & $7(0.8 \%)$ & $11(1.3 \%)$ \\
\hline Fever & $1(0.19 \%)$ & $9(1.0 \%)$ \\
\hline $\begin{array}{l}\text { Pharyngitis } \\
\end{array}$ & $7(0.8 \%)$ & $9(1.0 \%)$ \\
\hline Nausea & $4(0.5 \%)$ & $4(0.5 \%)$ \\
\hline Urticaria & $4(0.5 \%)$ & $5(0.6 \%)$ \\
\hline
\end{tabular}

At various time points after the infusion of immune Globulin Intravenous (Human), $10 \%$, serum samples were drawn to monitor the viral safety of the PID patients. Viral markers of hepatitis $C$, hepatitis $B$, HIV-1, and parvovirus B19 were monitored by nucleic
acid testing (NAT, Polymerase Chain Reaction [PCR]), and serological testing. There were no treatment related emergent fintings

Similar adverse reactions as for PID are expected tor the Immune Globulin Intravenous [Human], 10\% treatrment of patients with pediatric HWV infection or Allogeneic Bone Mat

Adverse reactions were monitored in two randomized clinical trials with more than 100 patients with acute or chronic ITP. In the tirst study (randomized and double-blind), 97 IIP patients were randomized to a single dose of $2000 \mathrm{mg} / \mathrm{kg}$ of
GAMUNEX a maximum infusion rate of $0.08 \mathrm{~mL} / \mathrm{kg} / \mathrm{min}$.

As expected, the adverse event rate for Immune Globulin Intravenous [Human], 10\% in this ITP trial was higher than observed in on two consecutive days rather than on five consecutive days, which is associated with a higher adverse tovent doase was given pre-medication with corticosteroids was permitted in the study protocol. More than $90 \%$ of the observed drug related adverse

The most frequently recorded drug related adverse events $(22.0 \%)$ are given in the table below:

\begin{tabular}{|c|c|c|}
\hline Incidence of drug related adverse events & GAMUNEX $X^{\prime M}(n=48)$ & GAMIMUNEE $N$ N 10\% $(n=49)$ \\
\hline $\begin{array}{l}\text { Headache } \\
\text { Mlld } \\
\text { Moderate } \\
\text { Severe } \\
<\text { Day } 3 \\
\text { >Day } 3 \\
\end{array}$ & $24(50 \%)$ & $\begin{array}{r}18 \% \\
20 \% \\
12 \% \\
49 \% \\
0 \% \\
\end{array}$ \\
\hline $\begin{array}{l}\text { Vomiting } \\
\text { Mild } \\
\text { Moderate } \\
\text { Severe } \\
\text { < Day 3 } \\
\text { >Day 3 } \\
\end{array}$ & $6(13 \%)$ & $\begin{array}{r}10 \% \\
6 \% \\
0 \% \\
16 \% \\
0 \%\end{array}$ \\
\hline Fever & $5(10 \%)$ & $5(10 \%)$ \\
\hline Nausea & $5(10 \%)$ & $4(8 \%)$ \\
\hline Rash & $3(60 \%)$ & $0(0 \%)$ \\
\hline Back Pain & $3(6 \%)$ & $2(4 \%)$ \\
\hline Astheria & $2(4 \%)$ & $3(6 \%)$ \\
\hline Arthralgia & $2(49 \%)$ & $0\{0 \%)$ \\
\hline Pruritus & $2(4 \%)$ & $0(0 \%)$ \\
\hline Dizziness & $1(2 \%)$ & $3(640)$ \\
\hline Neck Pain & $0(0 \%)$ & $2(4 \%)$ \\
\hline
\end{tabular}


The intusion rate was reduced for only 4 of the 97 treated patients ( 1 GAMUNEX
Mild to moderate heaclache, nausea, and fever were the reponted reasons There were no anaphylactic or anaphylactoid reactions, At various time points after the infusion of Imminurie Globulin intravenous (Humani), 10\%, serum samples were drawn to monitor

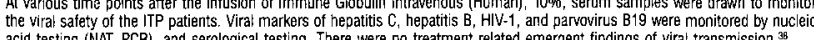

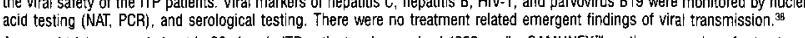
A second triat was carried out in 28 chronic ITP patients who received $1000 \mathrm{mg}^{2} / \mathrm{kg}$ GAMUNEX'w on three occasions for treatrent of relapses to determine tolerability of various infusion rates. The maximum infusion rate on the three occasions was randornly
assigned to $0.08,0.11$, or $0.14 \mathrm{~mL} / \mathrm{kg} / \mathrm{min}$ (8, 11 or $14 \mathrm{mg} / \mathrm{kg} / \mathrm{min}$ ) in which each patient was to receive Immune Globulin Intravenous (Human), 10\%, at all 3 rates. No pre-medication with corticosteroids to alleviate intusion-related intolerabiity wa permitted. Seven patients did nat complete the study for the following reasons: one adverse event (hives) at the $0.08 \mathrm{~mL} / \mathrm{kg} / \mathrm{min}$
level, one patient withdrew because he refused to participate without a forbidden concomitant medication (prednisone) and five

The number of patients who experienced at least one adverse event for the 0.08 . 0.11 , and $0.14 \mathrm{~mL} / \mathrm{kg} / \mathrm{min}$ infusion rates was
$12(46 \%), 13(59 \%)$, and $11(46 \%)$, respectively. The most commonly reported adverse event was headache, which occurred

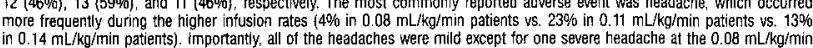
rate. Otherwise, the incidence rates of adverse events and drug-reated adverse events generally appeared to be simlar among the three infusion groups. No patients experienced a drug related serious adverse event. There were no other abnormal satety DOSAGE AND ADMINISTRATION

General

For intravenous use only. Dosages for specific indications are incicated below, but in general, it is recommended that Immune Globulin Intravenous (Human), $10 \%$ be infused by itself at an initial rate of $0.01100 .02 \mathrm{~mL} / \mathrm{kg}$ body weight per minute for 30 minutes; if well-tolerated, the rate may be gradually increased to a maximum of $0.14 \mathrm{mLL} / \mathrm{kg}$ body weight per minute. Clinical
investigations indicate that Immune Globulin Intravenous (Human), $10 \%$ is well-tolerated and less likely to produce side effecets when infused at the recommended rate. If side effects occur, the rate may be reduced, or the infusion interrupted until symptoms subside. The infusion may then be resumed at the rate which is comfortable tor the patient. Parenteral drug products should be
inspected visually for particulate matter and discoioration prior to administration, whenever solution and container permit. For patients judged to be at increased risk for developing renal dystunction, it may be prudent to reduce the amourt of product infused per unit time by infusing GAMUNEX' (Immune Globulin Intravenous [Human], 10\%) at a rate less than $8 \mathrm{mg} / \mathrm{kg} / \mathrm{min}$
$(0.08 \mathrm{~mL} / \mathrm{kg} g \mathrm{~min})$. No prospective data are presentity available to identify a maximum safe dose, concentration, and rate of intusion in patients deternined to be at increased risk of acute renal failure. In the absence of prospective data, recommended the of acute renal failure.

Pilmary Humoral Immunodefliciency

GAMUNEX' doses between 100 and $600 \mathrm{mg} / \mathrm{kg}(1$ and $6 \mathrm{~mL} / \mathrm{kg}$ administered every 3 or 4 weeks) may be used for infection

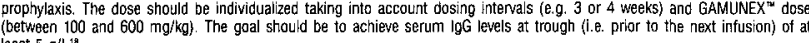

least $5 \mathrm{~g} / \mathrm{L}^{19}$
Idlopatic Thrombocytopenic Purpure

GAMUNEX'" may be administered at a total dose of $2000 \mathrm{mg} / \mathrm{kg}$, divided into two doses of $1000 \mathrm{mg} / \mathrm{kg}$ ( $10 \mathrm{~mL} / \mathrm{kg}$ ) given on two consecutive days, or into five doses of $400 \mathrm{mg} / \mathrm{kg}$ ( $4 \mathrm{~mL} / \mathrm{kg}$ ) given on five consecutive days. If after adrmiristration of the first of two daily $1000 \mathrm{mg} / \mathrm{kg}$ ( $(10 \mathrm{~mL} / \mathrm{kg}$ ) doses, an adequate increase in the platelet count is observed at 24 hours, the second
dose of $1000 \mathrm{mg} / \mathrm{kg}$ body weight may be withreld. The nigh dose regimen (1000 $\mathrm{mg} / \mathrm{kg} \times 1.2$ days) is not recommended for individuals with expanded fluid volumes or where fluid

Allogeneic Bone Marrow Transplantation (BMT)

An equivalent dosage of $500 \mathrm{mg} / \mathrm{kg}$ GAMUNEX $(5 \mathrm{~mL} / \mathrm{kg}$ ) is recormimended beginning on days 7 and 2 prior to transplantation (of at the time conditioning therapy for transplantation is begin), then weekly through 90 days atter transplantation. GAMUNEX

Pediatic HIV Intection

An equivalent dosage of GAMUNEX ${ }^{m}$ is recommended in doses of $400 \mathrm{mg} / \mathrm{kg}(4 \mathrm{~mL} / \mathrm{kg})$ body we ght every 28 days

Administration

It is recommended that GAMUNEEx' should initially be infused at a rate of 0.01 to $0.02 \mathrm{~mL} / \mathrm{kg}$ per minute 1 to $2 \mathrm{mg} / \mathrm{kg}$ per minues (14 mgikg per minute). If side effects occur, the rate may be reduced, or the inthe
infusion may then be resilmed at the rate, which is comfortable for the patient.

In a clinical trial with 28 chronic adult ITP patients receiving $1000 \mathrm{mg} / \mathrm{kg}$ GAMUNEX' to treat relapses, the infusion rate could be sately increased up to $0.14 \mathrm{~mL} / \mathrm{kg}$ per minute (14 $\mathrm{mg} / \mathrm{kg}$ per minute), ${ }^{35}$ Caution should
higher than $0.08 \mathrm{~mL} / \mathrm{kg}$ per minute (8 $\mathrm{mg} / \mathrm{kg}$ per minute) is administered for the first time.

Only 18 gauge needles should be used to penetrate the stopper for dispensing product from $10 \mathrm{~mL}$ vial sizes; 16 gauge needles or dispensing pins should only be used with $20 \mathrm{~mL}$ vial sizes and larger. Needles or dispensing pins should only be inserte within the stopper area delineated by the raised ring. The stopper should be penetrated perpendicular to the plane of the stopper

列 It is recommended to infuse GAMUNEX ${ }^{\mathrm{w}}$ using a separate line by itself, without mixing with other intravenous fluids of
medications the patient might be receiving. GAMUNEX medications the patient
(Human) formulation.

GAMUNEX'm is not compatible with saline. If dilution is required, GAMUNEX ${ }^{m}$ may be diluted with $5 \%$ dextrose in water (D5W) No other drug interactions or compatibilities have been evaluated. A number of factors beyond our control could reduce the efficacy of this product or evern result in an ill effect following its use.
These include improper storage and handling of the product atter it leaves our hands, diagnosis, dosage, method of adminis-
tration, and biological differencess in individual patients. Because of these factors, it is important that this product be stored tration, and biological differencess in individual patients. Becauss
properly and that the directions be followed carefully during use.

\section{PHARMACEUTICAL IMFORMATION}

GAMUNEX"' (Immune Globullin Intravenous [Human], 10\%) manufactured by a patented Chromatography Process is a ready-to-

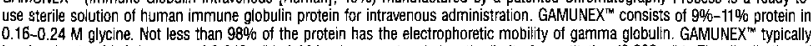
has low levels of lgA (average of $0.046 \mathrm{~g} / L$. IgM levels were at of below the limit of quantitation $(0.002 \mathrm{~g} / L$. The The distribution of $\lg G$ subclasses is similar to that found in normal serum. The measured buffer capacity is $35 \mathrm{mEg} / \mathrm{L}$ and the osmolality is GAMUNEX'" is made from large pools of human plasma by a combination of cold ethanol fractionation, caprylate precipitation and filtration, and anion-exchange chromatography. Part of the fractionation may be performed by another licensed manufacturer Two ethanol fractionation steps of the classical Cohn-Oncley process have been replaced by tandern anior-exchange
chromatography. The lga proteins are not subjected to heating or chemical or enzymatic modification steps. Fc and Fab tunctions of the lgG molecule are retained, but do not activate complement or pre-Kallikrein activity in an unspecific manner. The protein is stabilized during the process by adjusting the $\mathrm{pH}$ of the solution to $4.0-4.5$. Isotonicity is achieved by the addition of glycine.
GAMUNXX'

The capacity of the manufacturing process to remove andior inactivate enveloped and non-enveloped viruses has been validated by laboratory spiking studies on a scaled down process model, using the following enveloped and non-enveloped viruses:

Spiking Study Virus used:

\begin{tabular}{|l|l|}
\hline Human Immunodeficiency Virus type 1 (HIV-1) & HiV-1 and HIV-2 \\
\hline Bovine Viral Diarrhea Virus (BVDV) & Hepatitis C virus \\
\hline Pseudorabies Virus (PRV) & Hepatitis B and herpes virus \\
\hline Reo virus type 3 (Reo) & non enveloped virus \\
\hline Mepatitis A virus (HAV) & non enveloped virus \\
\hline
\end{tabular}

\section{Mepatitis A virus (HAV)}

porcine parvovirus (PPV) human parvovirus $B 19$

The following process steps contribute to virus inactivation and/or removal: caprylate precipitation and cloth filtration, caprylate incubation, column chromatography, and final container low $\mathrm{PH}$ incubation. Ine table below indicates how the viruses are
affected by the different steps. A number of virus removal steps were evaluated independently and in combination to identify those steps which are mechanistically distinct. Overall virus reduction was calculated only from steps that are mechanistically independent from each other and truly additive
production range for key operating parameters

\begin{tabular}{|c|c|c|}
\hline Progers step & Enveloped viruses & Man-envelopad viruses \\
\hline Cappylate precipitation and cloth filtration & Robust removal of BVoV; not claimed for ther enveloped viruses' & Robust removal \\
\hline Caprylate incubation & Dedicated step, robust inactivation* & No effect \\
\hline Depth Filtration & Not claimed ${ }^{2}$ & Not claimed ${ }^{3}$ \\
\hline Column chromatography & Hobust removal & Robust removal" \\
\hline Final container low $\mathrm{pH}$ incubation & Dedicated step, robust inactivation * & No effect: \\
\hline
\end{tabular}

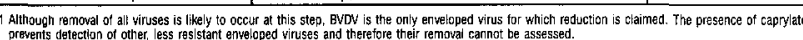

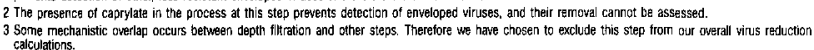

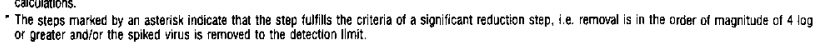
Data derlved trom prion spiking studies have shown that the GAMUNEX ${ }^{m}$ process has the potential to remove animat model
prions. ${ }^{\prime 2}$

Glycine (aminoacetic acid) is a nonessential amino acid normaly present in the body. Glycine is a major ingredient in amino acio
solutions employed in intravenous alimentation. 4 While toxic effects of dyycine administration have been reported 42 the doses

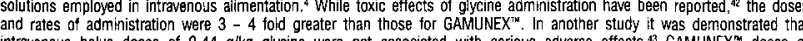

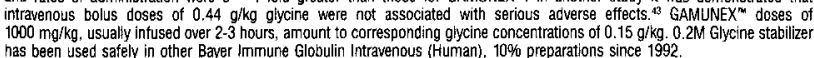

The buffering capacity of GAMUNEX' is $35.0 \mathrm{mEgh}$ (0.35 mEg/g protein). A dose of $1000 \mathrm{mg} / \mathrm{kg}$ body weight therefore $45-50 \mathrm{mEg} / \mathrm{L}$ of blood, or $3.6 \mathrm{mEg} / \mathrm{kg}$ body weight. ${ }^{3}$ Thus, the acid load delivered with a dose of $1000 \mathrm{mg} / \mathrm{kg}$ of GAMUNEX would be neutralized by the buftering capacity of whole blood alone, even if the dose was intused instantaneously. Storage

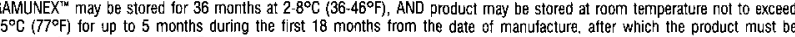
mmediately used or discarded. Do riot freezz. Do not use atter expiration date.

AVALABILITY OF DOSAGE FORMS

GAMUNEX' (Imrrinuna Globulin Intravenous [Human], 10\%) is supplied in the following sizes:

$\begin{array}{lc}\text { Size. } & \text { Protein (a) } \\ 10 \mathrm{~mL} & 1.0 \\ 25 \mathrm{~mL} & 2.5 \\ 50 \mathrm{~mL} & 5.0 \\ 100 \mathrm{~mL} & 10.0 \\ 200 \mathrm{~mL} & 20.0\end{array}$

REFERENCES

1. Lee DG, Stertland CJ, Harrwell RC, Ford EK, Ca K, Miller JL, et al. Manitoring plasma processing steps with a sensitive Western

2. Lee DC, Stenland CJ, Milier JL, Cai K, Ford EK, Gilligan KJ, et at. A direct relationshio between the partitioning of the pathogenic prion protein and

3. Guyton AC. Clinical measurements for study of acid-base abno
London, Toronto: W. B. Saunders Company; 1976. p. 499-500

4. Wrettind A. Complete intravencus nutrition. Theoretical and experimental background. Nutr Metab 1972; 14(Suppli): 1-57.

5. Bayever E, Monteagudo F, Sundaresan $P$, Collins $S$. A rancomized, doubleblind, multicenter, repeat dosing, cross-over triza

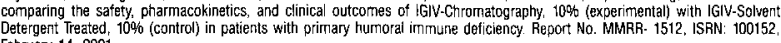

6. Lathia C, Emir B, Schwartz L. A randornized, open-label, multicenter, repeat dosing, cross-cvere trial comparing the satety, pharma-

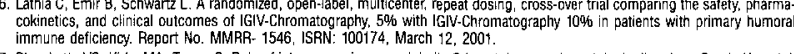

Blanchette VS, Kirby MA, Turner C. Rote of intravenous inmunoglobulin $G$ in autoimmune hematologic disorders, Sermin Hemato

8. Lazarus AH, Freedman J, Semple. JW Intravenous immunoglobulin and anti-D in idiopathic thrombocytopenic purpura (ITP)

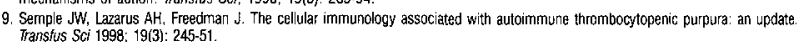

10. Imbach PA. Harmful and beneficial antibodies in immune thrombocytopenic purpura. Clin Exp Immunoi 1994: 97/(Suppl 1): 25-30. 11. Bussel JB. Fc receptor blockade and immune thrombocylopenic purpura. Semin Hemator 2000; 37(3): 261.6.

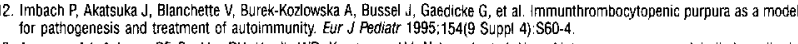

13. Ammann AJ, Ashman RF, Buckley RH, Hardie WR, Krantraann HJ. Nelson $\mathrm{s}$, et al. Use of intravenous gamma-globulin in antibody 14. Buckley RH, Schiff RI. The use of intravenous inmune globuln in immunodeficiency diseases. N Engl J Med, 1991; 325(2): 110-7. 32 15. Cunningham-Rundes C, Bodian C. Common variable immuniodeficiency: clinical and immunological ieatures of 248 patients. Chin

16. Nolte MT, Pirotsky B, Gerritz GA, Golding B. Intravenous immunoglobulin therapy for antibody deficiency Clin Exp immunot

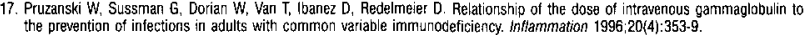

18. Roirman $\mathrm{CM}$, Levison $\mathrm{H}$, Geltanci $\mathrm{EW}$. High-dose versus low-dose intravenous immunoglobulit in hypogammaglobulinaemia and

19. Sorensen RU, Polmar SH. Efficacy and safety of high-dose intravenous immune globulin therapy for antibcdy deficiency syndromes.

20. Stephan JL, Vlekova V, Le Deist $F$, Blanche $S$, Donadieu J, De Saint-Basile G, et al. Severe combined immunodeficiency: a

21. Sullivan $K M$, Kopecky $K J$ Joccom J Fisher $L$. Buckner $C D$. Meyers $J D$, et al. immunomodulatory and antimicrobial efficacy of

intraverous immunoglobulin in bone marrow transplartation. N EngI $J$ Med 1990:323(11):705-12. 22. Sullivan KM. Immunomodulation in aillogeneic marrow transplantation:
gratt-versus-host disease. Chin Exp Immunol 1996; 104(Suppl 1) 43 -8.

3. Spitzer TR, Cottler-Fox M, Sullivan P. Lynch M. Teftt MC, PIckle LW, et al. Continuous infusicn intravenous immunoglobulin is associated with a reduced incidence of intection and achieves higher serum immunoglobulin $Q$ levels than intermittent infusion 24. Bass EB, Powe NR, Goodman SN, Graziano SL, Griffiths RI, Kickler TS, et al. Etficacy of immune globulin in preventing compli-
cations of bone marrow transplantation: a meta-analysis. Bone Marrow Transolant 1993:12(3):273-82.

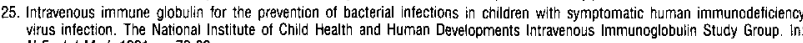
WV Engl J Med; 1991. p. 73-80.

26. Spector $S A$, Geiber RD, MGGrath N, Wara D, Barzilai A, Abrams $E$, et al. A controlled trial of intravencus immune globulin for the prevention of Serlous bacterial infections in children recelving zicovidine
Pediatric AlOS Clinical Trials Group. $N$ Engl $J$ Med 1994;331 118$): 1181-7$.

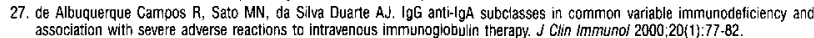
28. Koskinen $S$, Tolo $\mathrm{H}$, Hirvonen $M$, Koistinen J. Long-term foilow-up of ant-lgA antibocies in healthy lga-deficient adults. J Clin

29. Cunningham-Rundles $C$, Zhou $Z$, Mankarious $S$, Courter $S$. Long-term use of IgA-depleted intravenous immunoglobulin in

30. Litrman J B Broz P, Kral $\vee$. Lokaj J. [Successful gamma globulin therapy in a patient with anti-lgA antibodies]. Vnitr Lex

31. Cayco AV, Perazella MA, Hayslett JP. Renal insufficiency after intravenous immune globulin therapy: a report of two cases and an

32. Casteels-Van Daele $M$, Windaele $L$, Hanninck $K$, Gillis $P$. Intravenous immune globulin and acute aseptic mening tis. W Engi J

Med 1990:323(9):614-5.
33. Kato $E$, Shindo $S$, Eto $Y$, Hashimoto $N$, Yamamoto M, Sakata $Y$, et al. Administration of immune globulin associated with aseptic
meningitis, Jama 1988:259922? 3269-71.

34. Scribner CL, Kapit RM, Phillips ET, Rickles NM. Aseptic meningits and intravenous immunoglobulin therapy. Ann intern Med

35. Winward DB, Brophy MT. Acute renal falure after administration of intravenous irmmunoglobulin: review of the literature and case report. Pharmacotherapy $1995 ; 1566): 765-72$.

36. Peerless AG, Stiehm ER. Intravenous gammaglobulin for reaction to intramuscular preparation. Lancet 1983;2(8347) 461.

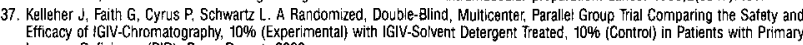

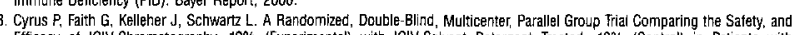

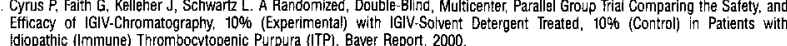
39. Keleher J, Sctwwartz L. IGIV-C 10\% Rapid infusion Trial in Idiooathic (IIminum
2001) Thrombocytopenic Purpura (ITP). Bayer Report, 40. George JN, Woolf SH, Raskob GE, Wasser JS, Aledort LM, Ballem PJ, et al. Idiopathic thrombocytopenic purpura: a practice

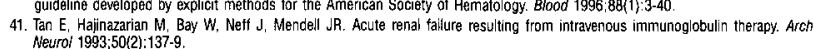
42. Hahn $R G$, Stalberg $H P$, Gustafsson $S A$. Intravenous intusion of irrigating fluids containing glycine or mannitol with and without

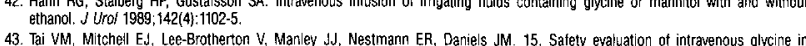
43. Tai VM, Mitcheil $\mathrm{E}$, Lee-Brotherton V, Marley SJ, Nestmann ER, Dariels JM. 15. Safety evaluation of intravenous glycine in
tormulation development. Pharm Pharmaceut Sci 2000:3(1):198. 44. Karatchkine MD, Kaveri SV. Immun

45. Koski CL. Therapy of C:DP and related imrnunie-mediated neuropathies. Neusrology 2002:59(12 Suppl 6):522.7.

46. Lemm $G$. Composition and properties of IVlg preparations that affect tolerability and therapeutic efficacy. Neurology 2002:59

08841855 (Rev. Juiy 2003)

Product Monograph available upon request.

References for advertisement on adjacent pages

1. Gamunex Th Product Monograph, August 11, 2003. Bayer Inc

2. Data on File, Bayer Inc.

Imported by:

(A) B. Bayer HealthCare

R\&D PAA

77 Belfield Road

Toronto, Ontario
M9W 1 G6 CANADA

BP254-1201 
PRESCRIBING INFORMATION

QReminyl

"REEMINYL*

galantamine hydrobromide tablets

$4 \mathrm{mg}, 8 \mathrm{mg}, 12 \mathrm{mg}$ galantamine base

Cholinesterase Inhibitor

CLINICAL PHARMACOLOGY

Although the etiology of cognitive impaiment in Alzheimer's Disease (AD) is no fully understood, it has been reported that acetycholine-producing neuron degenerate in the brains of patients with Azheimer's Disease. The degree of this cholinergic loss has been correlated with degree of cognitve impairment and density of amyloid plaques (a neuropathological hallmark of Alzheimer's Disease)

REMINYL (galantamine hydrobromide), a tertiary alkaloid, is a competitive and reversible cholinesterase inhibitor. While the precise mechanism- of calantamine's action is unknown, it is postulated to exert its therapertic ettect concentration of acetycholine through reversible cholinesterase inhibition. It has also been postulated, based on in vitro data, that galantamine enhances the action of acetylcholine through binding to an allosteric site on the nicotinic receptors (see PRECAUTIONS). The clinical relevance to humans of these in vitro findings is unknown

If these mechanisms are correct, galantamine's effect may lessen as the disease process advances and fewer cholinergic neurons remain functionally intact. There is no evidence that galantamine alters the course of the underlying dementing process.

\section{Pharmacokinetics}

\section{Absorption}

The summary of related pharmacokinetic parameters in healthy subjects is presented in Table 1. After oral intake of a single $8 \mathrm{mg}$ galantamine solution in 12 healthy males, absorption is rapid, with a peak plasma concentration $\left(C_{m}\right.$ of $43 \pm 13 \mathrm{ng} / \mathrm{mL}$, which is reached after 1.2 hours $\left(T_{\mathrm{mm}}\right)$, and a mean AUC. of $427 \pm 102 \mathrm{ng} . \mathrm{h} / \mathrm{mL}$.

The absolute oral bioavailability of galantamine is $88.5 \%$. Bioavailability of the tablet was the same as the bioavailability of an oral solution in 27 healthy males Food did not affect the AUC of galantamine but $\mathrm{C}_{\max }$ decreased by $25 \%$ and $\mathrm{T}_{\mathrm{m}}$ was delayed by 1.5 hours after repeated oral dosing of $12 \mathrm{mg}$ galantamine bi.d. in 24 healthy elderly subjects.

The maximum inhibition of anticholinesterase activity of about $40 \%$ was achieved about one hour after a single oral dose of $8 \mathrm{mg}$ galantamine in healthy male subjects.

Table 1. Pharmacokinetic parameters of galantamine after single or multiple dose
administration

\begin{tabular}{|c|c|c|c|c|c|c|}
\hline & $\underset{(\mathrm{ng} / \mathrm{mL})}{\mathrm{C}_{m}}$ & hin & $\underset{(\mathrm{ng} / \mathrm{mL})}{\mathrm{C}}$ & $\underset{(\mathrm{ng} / \mathrm{mL})}{\mathrm{C}}$ & $\begin{array}{c}\text { AUC' } \\
\text { (ng. } / \mathrm{h} / \mathrm{m} \text { ) }\end{array}$ & $\begin{array}{l}T_{1 n} \\
\text { (h) }\end{array}$ \\
\hline \multicolumn{7}{|c|}{ Single dose, 12 healthy males } \\
\hline $8 \mathrm{mg}$, solution p. 0. & $42.6 \pm 13.1$ & $1.2 \pm 0.6$ & - & $=$ & $427 \pm 102$ & $7.3 \pm 1.7$ \\
\hline $8 \mathrm{mg}, 1 \mathrm{hr}$ i.v. infusion & - & - & - & - & $482 \pm 112$ & $7.4 \pm 1.7$ \\
\hline \multicolumn{7}{|c|}{ Food effect, single dose, 24 healthy eiderly } \\
\hline Fasted, $8 \mathrm{mg}$ p.o. & $57.5 \pm 15.8$ & $1.1 \pm 0.5$ & - & - & $562 \pm 180$ & $9.7 \pm 3.1$ \\
\hline Non-fasted, $8 \mathrm{mg}$ p.o. & $42.5 \pm 7.5$ & $2.6 \pm 1.4$ & - & - & $543 \pm 176$ & $9.7 \pm 3.3$ \\
\hline \multicolumn{7}{|c|}{ Multiple oral dose, 27 healthy males } \\
\hline $12 \mathrm{mg}$ b.i.d. tablet & $89.4 \pm 18.3$ & $1.0 \pm 0.6$ & $51.9 \pm 12.2$ & $30.7 \pm 10.3$ & $623 \pm 147$ & - \\
\hline $12 \mathrm{mg}$ b.i.d. solution & $87.6 \pm 20.5$ & $1.1 \pm 0.5$ & $50.5 \pm 13.0$ & $29.8 \pm 10.2$ & $606 \pm 156$ & - \\
\hline \multicolumn{7}{|c|}{ Dose-proportionality, multiple oral dose, 18 healthy subjects } \\
\hline $4 \mathrm{mg}$ b.i.d. tablet & $30.7 \pm 6.2$ & $1.9 \pm 0.8$ & $17.7 \pm 4.6$ & $10.6 \pm 4.0$ & $212 \pm 56$ & - \\
\hline $8 \mathrm{mg}$ b.i.d. tablet & $63.8 \pm 14.2$ & $1.7 \pm 0.8$ & $36.6 \pm 9.8$ & $20.6 \pm 6.8$ & $439 \pm 117$ & - \\
\hline $12 \mathrm{mg}$ b.i.d. tablet & $97.4 \pm 31.4$ & $1.9 \pm 1.1$ & $53.1 \pm 12.7$ & $29.1 \pm 9.3$ & $637 \pm 152$ & - \\
\hline $16 \mathrm{mg}$ b.i.d. tablet & $137 \pm 36$ & $1.7 \pm 0.9$ & $76.5 \pm 20.3$ & $41.5 \pm 14.2$ & $918 \pm 244$ & $7.9 \pm 0.8$ \\
\hline
\end{tabular}

Elimination

The elimination of galantamine is bi-phasic, with a terminal half-life in the order of 7.8 hours in young healthy subjects ( $n=4$ males). Two studies in healthy elderly subjects indicated that the terminal half-life of galantamine is 8.5 hours $(n=13$ males and 16 temales) and 9.7 hours ( $n=10$ males and 14 females) atter administering a single oral dose of $10 \mathrm{mg}$ galantamine. Up to 8 hours post-dose. unchanged galantamine accounted for $39-77 \%$ of the total radioactivity in the plasma, and galantamine glucuronide accounted for $14-24 \%$. Seven days after a single oral dose of $4 \mathrm{mg}$ H-galantamine, $93-99 \%$ of the radioactivity had been recovered, with about $95 \%$ in urine and about $5 \%$ in feces. Total urinary recovery of unchanged galantamine accounted for, on average, $32 \%$ of the dose, and that of galantamine glucuronide for another $12 \%$ on average

After i.v. and oral administration, about $20 \%$ of the dose was excreted as unchanged galantamine in the urine in 24 hours, with a renal clearance of about $65 \mathrm{~mL} / \mathrm{min}$, which represents $20-25 \%$ of the total plasma clearance of about $300 \mathrm{~mL} / \mathrm{min}$

\section{CYP206 Poor Metabolizers}

Approximately $7 \%$ of the normal population has a genetic variation that leads to reduced levels of activity of the CYP2D6 isozyme. Such individuals have been referred to as poor metabolizers. After a single oral dose of $4 \mathrm{mg}$ or $8 \mathrm{mg}$ galantamine, CYP206 poor metabolizers demonstrated a similar $\mathrm{C}_{\max }$ and about $35 \%$ AUC. increase of unchanged galantamine compared to extensive metabolizers.

A total of 356 patients with Alzheimer's disease enrolled in two Phase III studies were genotyped with respect to CYP206 $(n=210$ hetero-extensive metabolizers, 126 homo-extensive metabolizers, and 20 poor metabolizers), Population pharmacokinetic analysis indcated that there was a $25 \%$ decrease in median clearance in poor metabolizers compared to extensive metaboizers. Dasage adjustment is not necessary in patients identfied as pocr metabolizers as the dose of drug is individualy fitrated to tolerability due to observed inter-patient variability. Hepatic impaimen

Following a single $4 \mathrm{mg}$ dose of galantamine, the pharmacokinetics of galantamine in subjects with mild hepatic impairment $(n=8$; Child-Pugh score of 5-6) were similar to those in healthy subjects. In patients with moderate hepatic impaiment ( $n=8$; Child-Pugh score of 7-9), AUC and half-life of galantamine were increased by about $30 \%$ compared to normal subjects (see PRECAUTIONS and DOSAGE AND ADMINISTRATION,

Renal Impaiment

In patients with renal insufficiency, elimination of galantamine decreases with decreasing creatinine clearance. Following a single $8 \mathrm{mg}$ dose of galantamine AUC increased by $37 \%$ and $67 \%$ in moderately $(n=8$; creatinine clearance of 30 to $60 \mathrm{~mL} / \mathrm{min} / 1.73 \mathrm{~m}$ ) and severely $(n=9$; creatinine clearance of 5 to $29 \mathrm{~mL} / \mathrm{min} / 1.73 \mathrm{~m}$ ) renal-impaired patients compared to normal volunteers $(n=8)$ (see PRECAUTIONS and DOSAGE AND ADMINISTRATION).

Patients with Alzheimer's Disease

Data from clinical trials in patients indicate that there is a difference in total clearance after oral administration between patients with Alzheimer's Disease and healthy subjects (132) Lh versus 19.4 Lh) based on pooled population analysis. Therefore, the plasma concentrations of galantamine in elderly patients (median age 75 ) with Alzheimer's $30.40 \%$ higher than in healthy than in healthy young subjects
(median age 28). Gender and Race No specific pharmacokinetic study was performed to investigate the $g$ e n d e r differences. A population pharmacokinetic a $n$ a I ys is $(n=539$ males and 550 females) suggests that galantamine $\uparrow A \cup C=A \cup C$, atter single dose and $A \cup C=A U C$ - atter multiple dose Distribution

Galantamine is a low-clearance drug (plasma clearance of approximatel) $300 \mathrm{~mL} / \mathrm{min}$ ) with a moderate volume of distribution (average $\mathrm{Vd}_{\text {ss }}$ of $175 \mathrm{LC}$ after a one-hour i.v. infusion of $8 \mathrm{mg}$ galantamine in 12 healthy males.

The plasma protein binding of galantamine is $18 \%$ at therapeutically relevant concentrations, In whole blood, galantamine is mainly distributed to blood cells concentrations. In whole blood, galantamine is mainly distnouted to blood cells
$(52.7 \%)$ and plasma water $(39.0 \%)$, whereas the fraction of galantamine bound to plasma proteins is only $8.4 \%$. The blood-to-plasma concentration ratio of galantamine is 1.2

Metabolism

Galantamine is metabolized by hepatic cytochrome P450 enzymes, glucuronidated and excreted unchanged in the urine. In vitro studies indicate that cytochrome CYP2D6 and CYP3A4 are the major cytochrome P450 isoenzymes involved in the metabolism of galantamine, and inhibitors of both pathways increase oral bioavaliability of galantamine modestly (see PRECAUTIONS, DrugDrug Interactions). 0-demethylation, mediated by CYP2D6 is greater in extensive metabolizers of CYP206 than in poor metatolizers. In plasma from both poor and extensive metabolizers, however, unchanged galantamine and its glucuronid accounted for most of the sample radioactivity. clearance is about $20 \%$ lower in fernales than in males, which is explained by lower body weight in females.

Pharmacokinetic differences due to race have not been identified in a population pharmacokinetic analysis ( $n=1029$ White, 24 Black, 13 Asian and 23 other). Clinical Trials

Efficacy data for REMINYL (galantamine hydrobromide) in the symptomatic treatment of patients with Alzheimer's Disease were derived from 4 randomized double-blind, placebo-controled clinical trials in patients with probable Aizheimer's Disease [diagnosed by NINCDS-ADRDA criteria, with Mini-Menta State Examination Scores that were $\geq 10$ and $\leq 24$ ]. Doses studied were $8.32 \mathrm{mg} /$ day given as twice daily doses. In 3 of the 4 studies, patients were started on a low dose of $8 \mathrm{mg}$, then titrated weekly by $8 \mathrm{mg} / \mathrm{day}$ to 24 or $32 \mathrm{mg}$ as assigned (GAL-USA-1, GAL-INT-1, GAL-INT-2). In the fourth study (U.S. 4-week Dose-Escalation Fixed-Dose Study, GAL-USA-10) dose escalation of $8 \mathrm{mg} / \mathrm{da}$ accurred over 4 week intervals. The mean age of patients participating in the 4 REMIINM tria's was 75 years with a range of 41 to 100 . Approximately $62 \%$ of patients were women and $38 \%$ were men. The racial distribution was White daily dosing regimen; these also showed or suggested benefit but did not suggest an advantage over twice daily dosing. $94 \%$, Black $3 \%$ and other races $3 \%$. Two other studies examined a three times
Results for 2 of these studies are presented in this section. The data shown below were obtained from the intent-To-Traat population iाT analysis, ie. al patients who were randomized to treatment, regardless of whether or not they were able to complete the study. For patients unable to complete the study, their last observation while on treatment was carried forward and used at endpoint). Study Outcome Measures: In each study, the primary efficacy of REMINYL was evaluated using a dual outcome assessment strategy as measured by the Alzheimer's Disease Assessment Scale (ADAS-cog) and the Clinician's Interview Based Impression of Change (CBIC-plus).

The ability of REMINYL to improve cognitive performance was assessed with the cognitive subscale of the Alzheimer's Disease Assessment Scale (ADAS-cog). a multi-item instrument that has been extensively validated in longitudinal cohorts of Alzheimer's Disease patients. The ADAS-oog examines selected aspects of cognifive performance, including elements of memory, orientation, attention, reasoning, language and praxis.

The patients recruited as participants in each study had mean scores on the ADAS-cog of approximately 27 units, with a range from 5 to 69 . Experience gained in longitudinal studies of ambulatory patients with mild to moderate Alzheimer's Disease suggests that they gain 6 to 12 units a year on the ADAS-cog. Lesser degrees of change, however, are seen in patients with very mild or very advanced disease because the ADAS-cog is not uniformly sensitive to change over the course of the disease. The annualized rate of decline in the placebo patients participating in REMINYL trials was approximately 4.5 units per year

The ability of REMINYL to produce an overall clinical effect was assessed using a Clinician's Intervew Based Impression of Change that required the use of caregiver information, the CBBIC-plus. The CIBIC-plus used in the trials was a semi-structured instrument based on a comprehensive evaluation at baseline and subsequent time-points of 4 major areas of patient function: generai, cognitive, behavioural and activities of daily living. Clinical trials for investigational drugs have used a variety of CBBIC formats, each different in terms of depth and structure. As such, results from a CIBIC-plus reflect clinical experience from the trial or trials in which it was used and cannot be compared directly with the results of CBBIC-plus evaluations from other clinical trials.

Among the secondary measures of efficacy, the Alzheimer's Disease Cooperative Study, Activites of Daly Living Inventory (ADCS/ADL) was used. The ADCS/ADL is a caregiver-rated evaluation which yields a compound score derived from a categorical scale of 23 items concerning participation in activities of daily living U.S. Twenty-One-Week Fixed-Dose Study (GAL-USA-10)

In a study of twenty-one weeks' duration, 978 patients were randomized to doses of 8 , 16, or $24 \mathrm{mg}$ of REMMNL per day, or to placebo, each given in 2 divided doses. Treatment was initiated at $8 \mathrm{mg} /$ day for all patients randomized to REMINML, and increased by $8 \mathrm{mg} /$ day every 4 weeks Therefore, the maximum dose-escalation phase was 8 weeks and the minimum maintenance phase was 13 weeks (in patients randomized to $24 \mathrm{mg} /$ day of REMINYL).

Effects on the ADAS cog: Figure 1 illustrates the time course for the change from baseline in ADAS-cog scores for all four dose groups over the 21 weeks of the study. At 21 weeks of treatment, the mean differences in the ADAS-cog change scores for the REMIMML-treated patients compared to the patients on placebo were $0.8,2.9$ and 2.9 units for the 8,16 and $24 \mathrm{mg} /$ day treatments, respectively. The $16 \mathrm{mg} /$ day and $24 \mathrm{mg} /$ day treatments were statistically significantly superio to placebo and to the $8 \mathrm{mg} /$ day treatment. There was no statistically significan difference between the $16 \mathrm{mg} /$ day and $24 \mathrm{mg} /$ day dose groups.

Figure 1: Time-course of the Changes from Basetine in ADAS-cog Score (ITT Population)

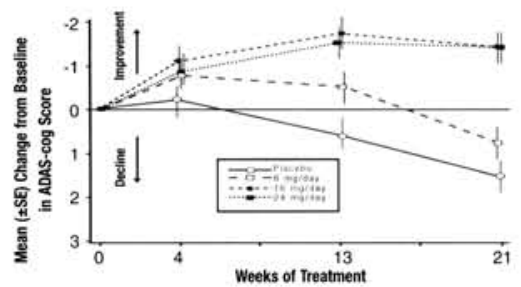

Figure 2 illustrates the cumulative percentages of patients from each of the four treatment groups who had attained at least the measure of improvement in ADAS-cog score shown on the X-axis. Three change scores (10-point, 7-point and 4-point reductions) and no change in score from baseline have been identifed for illustrative purposes, and the percentage of patients in each group achieving that result is shown in the inset table.

The curves demonstrate that both patients assigned to galantamine and placebo have a wide range of responses, but that the REMINYL groups are more likely to show the greater improvements.

Figure 2: Cumulative Percentage of Patients with Specified Changes from Baseline in ADAS-cog Scores (ITT Population)

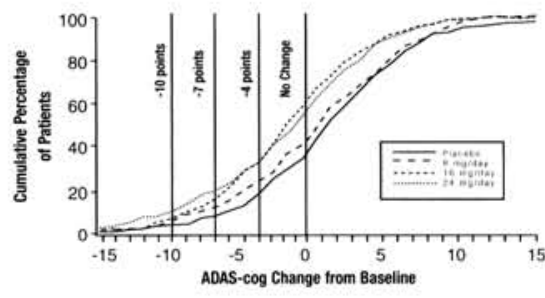




\begin{tabular}{|c|c|c|c|c|}
\hline \multirow[b]{2}{*}{ Treatment: } & \multicolumn{4}{|c|}{ Change in ADAS-cog } \\
\hline & -10 & -7 & -4 & 0 \\
\hline Placeto & $3.7 \%$ & $7.8 \%$ & $19.0 \%$ & $43.9 \%$ \\
\hline $8 \mathrm{mg} / \mathrm{day}$ & $4.5 \%$ & $11.4 \%$ & $22.7 \%$ & $47.7 \%$ \\
\hline $16 \mathrm{mg} / \mathrm{day}$ & $6.4 \%$ & $15.0 \%$ & $33.1 \%$ & $67.3 \%$ \\
\hline 24 mg/day & $8.8 \%$ & $19.8 \%$ & $32.4 \%$ & $62.6 \%$ \\
\hline
\end{tabular}

Effects on the CiBiC-Dius: Figure 3 is a histogram of the percentage distribution of CiBiC-plus scores attained by patients assigned to each of the four treatment groups. The REMINYL-placebo differences for these groups of patients in the mean rating were $0.10,0.32$ and 0.38 units for the 8,16 and $24 \mathrm{mg} / \mathrm{day}$ treatments, respectively. The $16 \mathrm{mg} / \mathrm{day}$ and $24 \mathrm{mg} /$ day treatments were statistically significantly superior to placebo. The differences vs. the $8 \mathrm{mg} / \mathrm{day}$ treatment for the 16 and $24 \mathrm{mg} /$ day treatments were 0.22 and 0.28 reaspectively. There were no statistically significant differences between the respectively. There were no statistically
$16 \mathrm{mg} / \mathrm{day}$ and $24 \mathrm{mg} /$ day dose groups.

Figure 3: Distribution of ClBIC-plus Ratings at Week 21 (IIT Population)

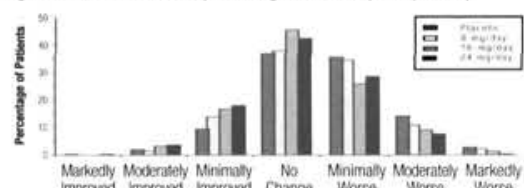

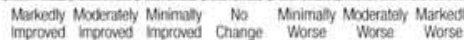
clisic-ples Rasion

Effects on ADCS/ADL Inventory: The Alzheimer's Disease Cooperative Study Activities of Daily Living Inventory was used as a secondary efficacy measure. A baseline, mean ADCS/ADL scores (mean \pm SE) were for the placebo group: 52.3 \pm 0.89 units; for the $16 \mathrm{mg} /$ day group: $51.6 \pm 0.93$ units; for the $24 \mathrm{mg} / \mathrm{day}$ group: $51.9+0.98$ units. At Week 21 , the placebo group declined an average of $3.9 \pm 0.55$ units, and the $16 \mathrm{mg} /$ day and $24 \mathrm{mg} /$ day groups deteriorated minimally at $1.0 \pm 0.51$ units and $1.6 \pm 0.56$ units, respectively. The difference between the placebo group and the galantamine treatment groups (16 mg/day or $24 \mathrm{mg} /$ day) was statistically significant.

US. Twenty-Six-Week Fixed-Dose Study (GAL-USA-1)

In a study of 26 weeks' duration, 636 patients were randomized to either a dose of $24 \mathrm{mg}$ or $32 \mathrm{mg}$ of REMINYL per day, or to placebo, each given in two divided doses. The 26-week study was divided into a 3-week dose-escalation phase and a 23-week maintenance phase.

EHects an the ADAS-cog. Figure 4 illustrates the time course for the change trom haseline in ADAS-cog score for all three dose groups over the 26 weeks of the study. At 26 weeks of treatment, the mean difference in the ADAS-cog change scores for the REMINYL-treated patients compared to the patients on placebo were 3.2 and 28 units for the $24 \mathrm{mg} /$ day and $32 \mathrm{mg} /$ day treatments. respectively. Both treatments were statistically significantly superior to placebo, but were not statistically significantly different from each other.

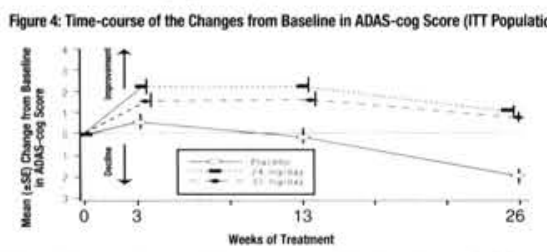

Figure 5 illustrates the cumulative percentages of patients from each of the three treatment groups who had attained at least the measure of improvement in ADAS-cog score shown on the X-axis. Three change scores (10-point, 7-point and 4-point reductions) and no change in score from baseline have been identfied for illustrative purposes, and the percent of patients in each group achieving that result is shown in the inset table.

The curves demonstrate that both patients assigned to galantamine and placebo have a wide range of responses, but that the REMINY. groups are more likely to show the greater improvements. Curve for an effective treatment would be shifted to the left of the curve for placebo, while an ineffective or deleterious treatment would be superimposed upon, or shifted to the right of the curve for placebo, respectively.

Figure 5: Cumulative Percentage of Patients with Specified Changes from Baseline in ADAS-cog Scores (ITT Population)

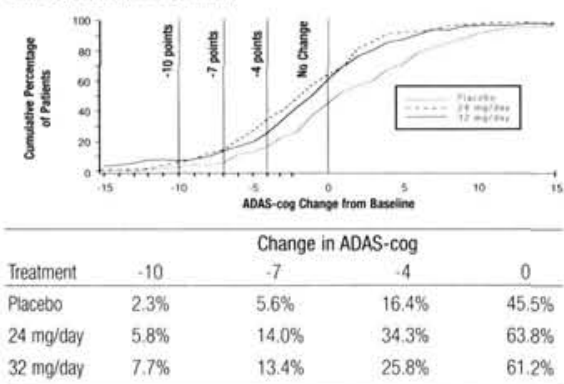

Effects on the CIBIC-plus. Figure 6 is a histogram of the percentage distribution of CBBIC-plus scores attained by patients assigned to each of the three treatmen groups. The mean REMINYL-placebo differences for these groups of patients in the mean rating were 0.22 and 0.17 units for 24 and $32 \mathrm{mg} /$ day of REMINYL. respectively. The mean ratings for both groups were statistically significantly superior to placebo, but were not significantly different from each other.

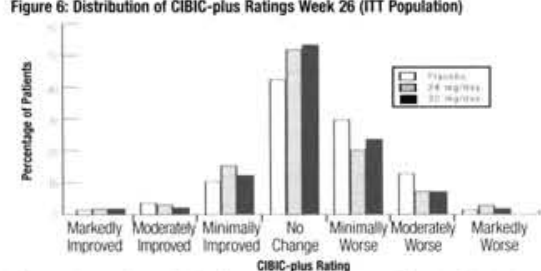

Age, gender and race: Patient's age, gender or race did not predict outcome of treatment.

\section{INDICATIONS AND CLINICAL USE}

REMINYL (galantamine hydrobromide) is indicated for the symptomatic treatment of patients with mild to moderate dementia of the Alzheimer's type. REMINYL has not been studied in controlled clinical trials for longer than 6 months.

REMINY should only be prescribed by (or following consultation with) clinicians who are experienced in the diagnosis and management of Alcheiner's Disease.

\section{CONTRAINDICATIONS}

REMENY (oalantamine hydrobromide) is contraindicated in patients with known hypersensitivity to galantamine hydrobromide, other tertiary alkaloid derivatives or to any excipients used in the formulation.

\section{WARNINGS}

\section{Anesthesia}

REMINYL (galantamine tiydrobromide), as a cholinesterase inhibitor, is likely to exaggerate succinyicholine-type muscle relaxation during anesthesia.

\section{Neurological Condition}

Seizures: In placebo-controlled trials with REMNYL, cases of seizute were reported, there was no increase in incidence compared with placebo. Cholinomimetics are believed to have some potential to cause generalized convuisions. However, seizure activity may also be a manifestation of Alzheimer's Disease. The riskbenefit of REMMNL treatment for patients with a history of seizure disorder must therefore be carefully evaluated

REMINYL has not been studied in patients with moderately severe or severe Alzheimer's Disease, non-Alzheimer dementias or individuals with Parkinson's Disease features. The efficacy and safety of REMINYL in these patient populations is unknown.

\section{Pulmonary Conditions}

Like other cholinomimetic drugs, REMINYL. should be prescribed with care for patients with a history of asthma or obstructive puimonary disease.

\section{Cardiovascular Condition}

Because of their pharmacological action, cholinesterase inhibitors have vagotonic effects on the sinoatrial and atrioventricular nodes, leading to bradycardia and heart block. These actions may be particularly impontant to patients with "sick sinus syndrome" or other supraventricular cardiac conduction disorders, or to patients taking other drugs concomitantly which significantly slow heart rate. In clinical trials, patients with serious cardiovascular disease were excluded. Caution should be exercised in treating patients with active coronary artery disease or congestive heart failure. It is recommended that REMINYL not be used in patients with cardiac conduction abnormalities (except for right bundle branch block) including "sick sinus syndrome" and those with unexplained syncopal episodes.

In randomized controlled trials, bradycardia was reported at $2.3 \%$ for galantamine doses up to $24 \mathrm{mg} /$ day compared with $<1 \%$ for placebo, and if rarely led to treatment discontinuation. No increased incidence of heart block was observed at the recommended doses. Patients treated with galantamine up to $24 \mathrm{mg} /$ day at the recommended dosing schedule showed a dose-related increase in risk of syncope (placebo, $0.7 \%$ [2/286]; $4 \mathrm{mg}$ b.i.d., $0.4 \%$ [3/692]: $8 \mathrm{mg}$ b.i.d. $1.3 \%$ [7/552]: $12 \mathrm{mg}$ b.i.d., $2.2 \%$ [6/273])

A 6-week cardiovascular safety clinical trial (GAL-USA-16; $n=139$ ) was performed to investigate the effect of galantamine at doses up to $32 \mathrm{mg} /$ day. This dosing regimen was: $8 \mathrm{mg} /$ day in Week $1,16 \mathrm{mg} /$ day in Week $2,24 \mathrm{mg} /$ day in Weeks 3 and 4 , and $32 \mathrm{mg} /$ day in Weeks 5 and 6 . Heart blockppauses greater than two seconds were more common in galantamine-treated patients than in placebo-treated patients. It should be noted that a forced 1-week dose escalation was used in this study, which is not recommended. Whether these cardiac effects are attenuated by slower titration rates is not known. Particular caution is warranted during titration where the majority of pauses occurred in the above study.

\section{Gastrointestinal Conditions}

Through their primary action, cholinesterase inhibitors may be expected to increase gastric acid secretion due to increased cholinergic activity. Therefore. patients should be monitored closely for symptoms of active or occult gastrointestinal bleeding. especially those with an increased risk for developing ulcers, e.g. those with a history of ulcer disease or patients using concurrent nonsteroidal anti-inflammatory drugs (NSAIDs). In controlled clinical studies with REMINYL, patients with symptomatic peptic ulceration were excluded. Clinical studies of REMINYL have shown no increase, relative to placebo, in the incidence of either peptic ulcer disease or gastrointestinal bleeding (see ADVERSE REACTIONS)

REMINYL, as a predictable consequence of its pharmacological properties, has been shown to produce nausea, vomiting and diarrhea. anorexia and weight loss. These effects appeared more frequently at higher doses (see ADVERSE REACTIONS), with nausea and vomiting being more prevalent in women and patients with lower body weight and correspondingly higher plasma drug concentrations. Females are more sensitive to the cholinergic adverse effects associated with cholinesterase inhibitors and in general are more likely to experience nausea and vomiting than are males. In most cases, these effects were of mild to moderate intensity and transient and have resolved during continued REMINYL treatment or upon treatment discontinuation

\section{Weight Loss}

Cholinesterase inhibitors as well as Alzheimer's Disease can be associater with significant weight loss. In controlled clinical trials, the use of REMNY was associated with weight loss. Weight decrease occurred early during treatment and was related to dose. Weight loss of $z 7 \%$ occurred more trequently in patients treated with REMINYL and in female patients than in patients receiving placebo. Where weight loss may be of clinical concern, body weight should be monitored.

\section{Genitourinary}

Although not observed in clinical trials of REMINM., cholinomimetics may cause bladder outlow obstruction

\section{PRECAUTIONS}

\section{Concomitant Use with Other Drugs}

Use with Anticholinergics

Because of their mechanism of action, cholinesterase inhibitors have the potential to interfere with the activity of anticholinergic medications

Use with Cholinomimetics and Other Choinesterase Inhibitors

A synergistic effect may be expected when cholinesterase inhibitors are given concurrently with succinylcholine, similar neuromuscular blocking agents of cholinergic agonists such as bethanechol.

Use with other Psychoactive Drugs

Few patients in the REMINYL (galantamine hydrobromide) clinical trials received neuroleptics, antidepressants or anticonvulsants, there is thus limited information concerning the interaction of REMINVL with these drugs,

\section{Use in Patients 285 Years 0ld}

in controlled clinical studies, the number of patients aged 85 years or over who received REMINM at theraneutic doses of 16 or $24 \mathrm{mg} /$ day was 123 . Of these patients, 70 received the maximum recommended dose of $24 \mathrm{mg} /$ day. There is limited safety information for REMINYL in this patient population.

Since cholinomimetics as well as Alzheimer's Disease can be associated with significant weight loss, caution is advised regarding the use of REMINY in elderly patients with low body weight, especially in those 285 years old.

\section{Use in Elderly Patients with Serious Comorbid Disease}

There is imited information on the satefy of REMINYL treatment in patients with mild to moderate Azheimer's Disease and serious/significant comortidity. The use of REMINYL. in Alzheimer's Disease patients with chronic ilinesses commo among the geriatric population, should be considered only atter carefu risk/benefit assessment and include close monitoring for adverse events. Dose escalation in this patient population should proceed with caution

\section{Renally and Hepatically Impaired Patients}

There is limited information on the pharmacokinetics of REMINYL in renally and hepatically impaired patients (see CUNICAL PHARMACOLOGY, Pharmacokinetics). It is therefore recommended that dose escalation with REMINM in Alzheimer's Disease patients with renal impairment (creatinine clearance of 9 to $60 \mathrm{~mL} / \mathrm{min}$ ) or hepatic impairment be undertaken with caution and under conditions of close monitoring for adverse effects (see DOSAGE AND ADMINISTRATION, Special Populations). Since no data are avaliable on the use of REMINYL in patients with a creatinine clearance of less than $9 \mathrm{~mL} / \mathrm{min}$ and in patients with severe hepatic impairment (Child-Pugh score of 10-15). REMINM is not recommended for these populations.

\section{Drug-Drug Interactions}

Multiple metabolic pattways and renal excrefion are involved in the elimination of galantamine so no single pathway appears predominant. Based on in vitro studies, CYP2D6 and CYP3A4 were the major enzymes involved in the metabolism of galantamine. CYP206 was involved in the formation of 0-desmethyl-galantamine, whereas CYP3A4 mediated the formation of galantamine $\mathrm{N}$-oxide.

Eftect of other Drugs on the Metabolism of REMINY.

Pharmacokinetic studies to assess the potential of REMINYL for interaction with cimetidine, ranitidine, ketoconazole, erythromycin, parovetine, wartarin and digoxin were limited to short-term, mostly single-dose studies in young healthy volunteers. Similar studies in elderly patients were not done. In vitro

CYP3A4 and CYP206 are the major enzymes involved in the metabolism of galantamine. CYP3A4 mediates the formation of galantamine $-\mathrm{N}$-oxide, whereas CYP2D6 is inwolved in the formation of 0-desmethyl-galantamine. Because galantamine is also glucuronidated and excreted unchanged in urine, no single patfiway appears predominant.

m vine

Cimetidine and Ranitidine: Galantamine was administered as a single dose of $4 \mathrm{mg}$ on Day 2 of a 3 -day treatment with either cimetidine $(800 \mathrm{mg}$ daily. $n=6$ males and 6 females) of ranitidine ( 300 mg daily; $n=6$ males and 6 females). Cimetidine increased the bioavailability of galantamine by approximately $16 \%$ Ranitidine had no effect on the pharmacokinetics of galantamine.

Ketoconazole: Ketoconazole, a strong inhibitor of CYP3A4 and an inhibitor of CyP206, at a dose of $200 \mathrm{mg}$ b.id for 4 days, increased the AUC of galantamine by $30 \%$ when subjects were treated with galantamine $4 \mathrm{mg}$ b.i.d. for 8 days ( $n=8$ males and 8 females).

Erythromycin: Erythromycin, a moderate inhibitor of CYP3A4 at a dose of $500 \mathrm{mg}$ qi.d. for 4 days increased the AUC of galantamine by $10 \%$ when subjects received galantamine $4 \mathrm{mg}$ b i.d. for 6 dars (n=8 males and 8 females). Paroxetine: Paroxetine, a strong inhibitor of CYP2D6, increased the AUC of $4 \mathrm{mg}$ b.i.d. $8 \mathrm{mg}$ b.id. and $12 \mathrm{mg}$ b.i.d. galantamine by $40 \%, 45 \%$ and $48 \%$, respectively, in 16 healthy volunteers $(8$ males and 8 temales) who received galantamine together with $20 \mathrm{mg} /$ day paroxetine. 


\section{Effect of Galantamine on the Metabolism of 0ther Drugs}

In vitro

Galantamine did not inhibit the metabolic pathways catalyzed by CYP1A2 CYP2A6, CYP3A4, CYP4A, CYP2C, CYP2D6 or CYP2E1. This indicates that the inhibitory potential of galantamine towards the major torms of cytochrome $\mathrm{P} 450$ is very low

in wivo

Warfarin: Galantamine at $12 \mathrm{mg}$ b.i.d. had no effect on the pharmacokinetics of R- and S-wartarin (25 $\mathrm{mg}$ single dose) or on the prothrombin time (n $=16$ males) The protein binding of warfarin was unatfected by galantamine.

Digoxin: Galantamine at $12 \mathrm{mg}$ b.i.d. had no effect on the steady-state pharmacokinetics of digoxin $(0.375 \mathrm{mg}$ once daily) when they were coadministered. In this study, however, one healthy subject was hospitalized for $2^{m}$

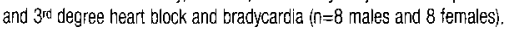
Nicotinic Receotor Modulation

Single in vitro applications of galantamine dose-dependently nodulate the effect on nicotinic receptors, having a positive allosteric (sensitizing) effect at concentrations below $0.28 \mathrm{\mu g} / \mathrm{mL}(1 \mathrm{\mu M})$ and an inhibitory effect at higher concentrations. Chronic in vitro or in vivo studies on nicotinic receptor modulation have not been conducted

It is unknown whether galantamine has an effect on the pharmacodynamic action of other drugs that act on cholinergic nicotinic receptors isee CLINICAL PHARMACOLOGY

\section{Carcinogenesis, Mutagenesis and Impairment of Fertillty}

In a 24-month oral carcinogenicity study in rats, a stight increase in endometrial adenocarcinomas was observed at $10 \mathrm{mg} / \mathrm{kg} / \mathrm{day}$ (4 times the Maximum Recommended Human Dose [MRHD] on a $\mathrm{mc} / \mathrm{m}^{2}$ basis or 6 times on an exposure [AUC] basis), and $30 \mathrm{mg} / \mathrm{kg} /$ day (12 times the MRHD on a $\mathrm{mg} / \mathrm{m}^{2}$ basis or 19 times on an AUC basisj). No increase in neoplastic changes was observed in fermales at $2.5 \mathrm{mg} / \mathrm{kg} /$ day (equivalent to the MRHD on a $\mathrm{mg} / \mathrm{m}^{2}$ basis or 2 times on an AuC basis) or in males up to the highest dose tested of $30 \mathrm{mg} / \mathrm{kg} / \mathrm{day}$ (12 times the MRHD on a $\mathrm{mg} / \mathrm{m}^{2}$ and AUC basis).

Galantamine was not carcinogenic in a 6-month oral carcinogenicity study in transgenic (P 53-deficient) mice up to $20 \mathrm{mg} / \mathrm{kg} / \mathrm{day}$, or in a 24 -month oral carcinogenicity study in male and female mice up to $10 \mathrm{mg} / \mathrm{kg} / \mathrm{day}$ (2 times the MRHD on a $\mathrm{mg} / \mathrm{m}$ ' basis and equivalent on an AUC basis)

Galantamine produced no evicence of genotoxic potential when evaluated in the in vitro Ames S. typhimurium or E. coli reverse mutation assay, in vitro mouse ymphoma assay, in vivo micronucleus test in mice, or in vitro chromosome aberration assay in Chinese hamster ovary cells.

No impairment of fertility was seen in rats given up to $16 \mathrm{mg} / \mathrm{kg} / \mathrm{day}$ (7 times the MRHD on a mg/m' basis) for 14 days prior to mating in females and for 60 days prior to mating in males.

\section{Pregnancy}

In a teratology study in which rats were dosed from Day 14 (females) or Day 60 (males) prior to mating through the period of organogenesis, a slightly increased incidence of skeletal variations was observed at doses of $8 \mathrm{mg} / \mathrm{kg} / \mathrm{day}$ ( 3 times the MRHD on a $\mathrm{mg} / \mathrm{m}^{2}$ basisi and $16 \mathrm{mg} / \mathrm{kg} /$ day. In a study in which pregnant rats were dosed fram the beginning of arganogenesis through Day 21 postpartum, pup weights were decreased at 8 and $16 \mathrm{mg} / \mathrm{kg} / \mathrm{day}$, but no adverse effects on other postnatal developmental parameters were seen. The doses causing the above effects in rats produced slight maternal toxicity. No major causing the above effects in rats produced slight maternal toxicity. No major
malformations were caused in rats given up to $16 \mathrm{mg} / \mathrm{kg} /$ day. No drug related teratogenic effects were observed in rabbits given up to $40 \mathrm{mg} / \mathrm{kg} /$ day (32 times the MRHD on a $\mathrm{mg} / \mathrm{m}^{2}$ basis; during the period of organogenesis.

The safety of REMINYL in pregnant women has not been established. REMINYL should not be used in women of childtbearing potential unless, in the opinion of the physician, the potential benefit to the patient justifies the potential risk to the fetus. Nursing Mothers

It is not known whether REMINYL is excreted in human breast milk and therefore REMINYL should not be used in nursing mothers.

\section{Pediatric Use}

The safety and effectlveness of REMNNYL in any illness occurring in pediatric patients have not been established.

\section{ADVERSE REACTIONS}

A total of 2287 patients with mild to moderate Alzheimer's Disease were treated with REMINYY (galantamine hydrobromide) in Phase III controlled clinical studies using either a 1-week or 4-week dose-escalation period, and 761 patients using either a 1 -week or 4 -week dose-escalation period, and 76 patents
received REMINYL. 24 mg/day, the maximum recommended maintenance dose. received REMMNYL $24 \mathrm{mg} /$ day, the maximum recommended maintenance dose.
The number of patients who completed the studies was $1686(72 \%)$. The mean duration of treatment for all REMINYL groups was 130 days (range 1-214 days).

\section{Adverse Events Leading to Discontinuation}

Overall, 19\% (441/2287) of patients treated with REMINYL discontinued from Phase II controlled clinical trials due to adverse events compared to $8 \%$ $(98 / 1159)$ in the placebo group. For patients treated with REMINYL, the rate of discontinuation due to adverse events was $14 \%$ for males and $22 \%$ for females. In the 4-week dose-escalation fixed-dose study (GAL-USA-10), 8\% (55/692) of patients treated with REMINYL withdrew due to adverse events compared to $7 \%$ (20/286) in the placebo group. During the dose-escalation phase of this study the incidence of discontinuations due to adverse events was $4 \%$ for placebo, $5 \%$ for REMINYL $16 \mathrm{mg} / \mathrm{day}$ and $6 \%$ for REMINYL $24 \mathrm{mg} /$ day. During the maintenance phase, $4 \%$ of patients who received placebo, $3 \%$ of patients who received REMNNY $16 \mathrm{mg} / \mathrm{day}$ and $4 \%$ of patients who received REMINYL $24 \mathrm{mg} /$ day withdrew from this study due to adverse events.

Table 1 shows the most frequent adverse events leading to discontinuation for study GAL-USA-10, in which the recommended 4-week dose-escalation schedule was used.

Table 1: Most frequent adverse events leading to discontinuation in a placebocontrolled, double-bilind trial with a 4-week dose-escalation schedule (GAL-USA-10)

\begin{tabular}{|l|c|c|c|}
\hline \multirow{2}{*}{ Adverse Events } & \multicolumn{3}{|c|}{ Recommended 4-week dose escalation } \\
\cline { 2 - 4 } & $\begin{array}{c}\text { Placebo } \\
\mathrm{n}=286\end{array}$ & $\begin{array}{c}16 \mathrm{mg} / \text { day } \\
\mathrm{n}=279\end{array}$ & $\begin{array}{c}24 \mathrm{mg} / \text { day } \\
\mathrm{n}=273\end{array}$ \\
\hline Nausea & $<1 \%$ & $2 \%$ & $4 \%$ \\
\hline Vomiting & $0 \%$ & $1 \%$ & $3 \%$ \\
\hline Anorexia & $<1 \%$ & $1 \%$ & $<1 \%$ \\
\hline Dizziness & $<1 \%$ & $2 \%$ & $1 \%$ \\
\hline Syncope & $0 \%$ & $0 \%$ & $1 \%$ \\
\hline
\end{tabular}

Most Frequent Adverse Glinical Events Seen in Association with the Use of REMINYL

The most frequent adverse events, defined as those occurring at a frequency of at least $5 \%$ and at least twice the rate of placebo in study GAL-USA-10, in which the recommended 4-week dose-escalation schedule was used are shown in Table 2. These events were primarily gastrointestinal and tended to occur at a lower rate with $\uparrow 6 \mathrm{mg} / \mathrm{day}$, the initial recommended maintenance dose.

Table 2: Most frequent adverse events in a randomized placebo-controlled clinical trial with a 4-wesk dose increment during dose-escalation and maintenance phases (GAL-UsA-10)
\begin{tabular}{|l|c|c|c|c|c|c|}
\hline & \multicolumn{5}{|c|}{ Week 1-12 } \\
\hline $\begin{array}{l}\text { Adverse } \\
\text { Events }\end{array}$ & $\begin{array}{c}\text { Placebo } \\
\mathrm{n}=286\end{array}$ & $\begin{array}{c}16 \mathrm{mg} / \mathrm{day} \\
\mathrm{n}=279\end{array}$ & $\begin{array}{c}24 \mathrm{mg} / \mathrm{day} \\
\mathrm{n}=273\end{array}$ & $\begin{array}{c}\text { Placebo } \\
\mathrm{n}=259\end{array}$ & $\begin{array}{c}16 \mathrm{mg} / \mathrm{day} \\
\mathrm{n}=243\end{array}$ & $\begin{array}{c}24 \mathrm{mg} / \mathrm{day} \\
\mathrm{n}=241\end{array}$ \\
\hline Nausea & $5 \%$ & $11 \%$ & $13 \%$ & $<1 \%$ & $4 \%$ & $6 \%$ \\
\hline Vomiting & $<1 \%$ & $5 \%$ & $6 \%$ & $<\%$ & $2 \%$ & $6 \%$ \\
\hline Diarrhea & $5 \%$ & $9 \%$ & $4 \%$ & $2 \%$ & $5 \%$ & $2 \%$ \\
\hline Anorexia & $2 \%$ & $5 \%$ & $5 \%$ & $1 \%$ & $2 \%$ & $5 \%$ \\
\hline
\end{tabular}

† Dose escalation occurred with 4 weeks per dose irerenent.

The majority of these adverse events occurred during the dose-escalation period. Nausea and voriting, the most frequent adverse events, occurred more frequently at higher doses, lasted 5-7 days in most cases, and the majority of patients had one episode. The incidence of weight loss in this study was, during dose escalation (Weeks 1-12): placebo, 1\%; $16 \mathrm{mg} / \mathrm{day}, 3 \% ; 24 \mathrm{mo} / \mathrm{day}, 2 \%$ and during the maintenance phase (Weeks 13-21): placebo, <1\%; $16 \mathrm{mg} / \mathrm{day}$; $3 \% ; 24 \mathrm{mg} / \mathrm{day}, 3 \%$

Dose escalation should be cautious and maintenance dosing should remain flexible and be adjusted accorcing to individual needs.

\section{Adverse Events Reported in Controlled Trials}

The reported adverse events in REMNYL trials reflect experience gained unde closely monitored conditions in a highly selected patient population. In actual practice or in other clinical trials, these frequency estimates may not apply, as the conditions of use, reporting behaviour and the types of patients treated may differ. Table 3 lists the most common adverse events ladverse events occurring with an incicence of $2 \%$ with REMINYL treatment and in which the incidence was greater than with placebo treatment for four placebo-controlled trials for patients treated with 16 or 24 mglay of REMINI The combined vaes presented in Table 3 were derived from trials using a 1 -week or the reconmended 4-week dose-escalation period.

Table 3: Adverse events reported in at least $2 \%$ of patients with Alzheimer's Disease administered REMWNYL and at a frequency greater than with placebo (combined 1- and 4-week dose-escatation data)

\begin{tabular}{|l|l|l|}
\hline Body System / Adverse Events & $\begin{array}{l}\text { Placebo } \\
(n=801)\end{array}$ & $\begin{array}{l}\text { REMINYL } \\
(n=1040)\end{array}$ \\
\hline Body as a whoie - general disorders & & \\
\hline
\end{tabular}

\begin{tabular}{|c|c|c|}
\hline \multicolumn{3}{|c|}{ Body as a whole - general disorders } \\
\hline Fatigue & $3 \%$ & $5 \%$ \\
\hline Syncope & $1 \%$ & $2 \%$ \\
\hline Central \& per & & \\
\hline
\end{tabular}

\begin{tabular}{|l|c|c|}
\hline Central \& peripheral nervous system disorders & & \\
\hline Dizziness & $6 \%$ & $9 \%$ \\
\hline Headache & $5 \%$ & $8 \%$ \\
\hline
\end{tabular}

\begin{tabular}{|c|c|c|}
\hline & & \\
\hline Headache & $5 \%$ & $8 \%$ \\
\hline Tremor & $2 \%$ & $3 \%$ \\
\hline \multicolumn{3}{|c|}{ Gastro-intestinal system disorders } \\
\hline Nausea & $9 \%$ & $24 \%$ \\
\hline Vomiting & $4 \%$ & $13 \%$ \\
\hline Diarthea & $7 \%$ & $9 \%$ \\
\hline Abdominal pain & $4 \%$ & $5 \%$ \\
\hline Dyspepsia & $2 \%$ & $5 \%$ \\
\hline
\end{tabular}

\begin{tabular}{|c|c|c|}
\hline Heart rate and mythm disorders & & \\
\hline Bradycardia & $1 \%$ & $2 \%$ \\
\hline
\end{tabular}

\begin{tabular}{|l|c|c|}
\hline Metabolic and nutritional disorders & & \\
\hline Weight decrease & $2 \%$ & $7 \%$ \\
\hline Psychiatric disorders & & \\
\hline Anorexa & & \\
\hline
\end{tabular}

\begin{tabular}{|l|c|c|}
\hline Psychiatric disorders & & \\
\hline Anorexia & $3 \%$ & $9 \%$ \\
\hline Depression & $5 \%$ & $7 \%$ \\
\hline Insomnia & $4 \%$ & $5 \%$ \\
\hline Somnolence & $3 \%$ & $4 \%$ \\
\hline Red blood cell disorders & & \\
\hline Anemia & $2 \%$ & $3 \%$ \\
\hline Respiratory system disorders & & \\
\hline Rhinitis & $3 \%$ & $4 \%$ \\
\hline Urinary system disorders & & \\
\hline Urinary tract infection & $7 \%$ & $8 \%$ \\
\hline Hernaturia & $2 \%$ & $3 \%$ \\
\hline
\end{tabular}

† Adverse events in patients treated with 16 or $24 \mathrm{mg} / \mathrm{day}$ of REMNML in three placeboTAdyerse events in patients treated with 16 or $24 \mathrm{mg} / \mathrm{cay}$ of REMINYL in three placebo-
controlled trials with a 1 - - wreek dose-escalation period and a 26 -week fixed-dose REMMNYL controlled trials with a 1-week dose-escalation period and a 26-week fixed-dose REMMNYM period and a 21-week fixed-dose REVMINYL treatment are inculused
No clinically relevant abnormalities in laboratory values were observed. In a cardiovascular safety clinical trial (GAL-USA-16) pauses greater than two seconds were more common in galantamine-treated patients than in placebotreated patients during the dose-escalation period (see WARNINGS)

\section{Oer Adverse Events Observed During Clinical Tria}

REMINYL has been administered to 3055 patients with Alzheimer's Disease during clinical trials worldwide.

A total of 2357 patients received galantamine in placebo-controlled trials and 761 patients with Alzheimer's Disease received gaiantamine $24 \mathrm{mg} / \mathrm{cay}$, the maximum recommended maintenance dose. About 1000 patents received galantamine for at least one vear and approximately 200 patients recelved galantamine for two years. To establish the rate of adverse events, data from all patients for any dose of REMINYL in 8 placebo-controlled trials and 6 open-label extension trials were pooled. The methodology to gather and codify these adverse everts was standardized across trials, using WHO terminology. All events occurring in approximately $0.1 \%$ of patents are included, except for those already isted elsewhere in labelling. WHO terms too general to be informative, or relatively minor events. Events are classified by body system and listed using the following definitions: frequent adverse events - those occurring in at least 1/100 patients: infrequent adverse events - those occurring in 1/100 to $1 / 1000$ patients. These adverse events are not necessarily related to REMINYL treatment and in most cases were observed at a similar frequency in placebo-treated patients in he controlled studies.

Body as a Whole - General Disorcers: Frequent: chest pain

Cardiovascular System Disorders: Frequent: hypertension; Infrequent: postufal hypotension, hypoter sion, dependent edema, cardlac failure.

Central \& Peripheral Nervous System Disorders: Infrequent: vertigo, hypertonia convulsions, involuntary muscle contractions, paresthesia, ataxia, hypokinesia hyperkinesia, apraxia, aphasia

Gastrointestinal System Disorders: Frequent: flatulence: Infrequent: gastrits, melena, dysphagia, rectal hemorrhage, dry mouth, saliva increased, divertic ulltis, gastroenteritis hiccus; Rare: esophageal pertoration.

Heart Rate \& Rhythm Disorders: infrequent: AV block, palpitation, atrial fibrilation, QT prolonged, bundle branch block, supraventicular tachycardia, $T$-wave inversion, ventricular tachycardia

Metabolic \& Nutritional Disorders: Infrequent: hyperglycemia, alkaline chosphatase increased, NPN increased.

Platelet. Bleeding \& Clotting Disorders: Infrequent: purpura, epistaxis, thrombocytopenia.

Ssychiatric Disorders: Infrequent: apathy, paroniria, paranoid reaction, libido increased, delirium.

Urinary System Disorders: Frequent incontinence; infrequent: hematuria micturition frequency, cystitis, urinary retention, nocturia, renal calculi.

\section{SYMPTOMS AND TREATMENT OF OVERDOSAGE}

\section{Symptoms}

Overdosage with cholinesterase Inhibitors can result in cholinergic crisis characterized by severe nausea, vorniting, salivation, sweating, bradycardia hycotension, respiratory depression, collapse and convulsons. Increasing muscle weakness is a possibility and may result in death if respiratory muscles are involved. In a postrnarketing report, one patient who had been taking $4 \mathrm{mg}$ of galantamine daily inadvertently ingested eight $4 \mathrm{mg}$ tablets $(32 \mathrm{mg}$ total) on the tenth day of treatment. Subsequently, she developed bradycardia, OT prolongation, entricular tachycardia and torsades de pointes accompanied by a brief loss of conscicusness for which she required hospital treatment. ECG obtained just prior to initiation of galantamine treatment was normal.

\section{Ireatment}

REMINYL (galantamine hydrobromide) has a plasma half-life of approximately 7-8 hours. It is recommended that, in case of asymptomatic overdose, no furthe dose of REMINYL should be administered and the patient should be monitored. As in any case of overdose, general supportive measures should be utilized. Signs and symptoms of significant overcosing of galantamine are predicted to be similar to those of overdosing of other cholinomimetics. These effects generally involye the central nervous system, the parasympathetic nervous system, and the neuromuscular junction. In addition to muscle weakness or tasciculations, some or all of the following signs of cholinergic crisis may develop: severe nausea, vomiting, gastrointestinal cramping, salivation, lacrimation, urination, defecation, sweating, bradycardia, hypotension resp ratory depression, collapse and convulsions. Increasing muscle weakness is a possibility and may result in death if respiratory muscles are involved. Tertiary anticholinergics such as atropine may be used as an antidote for REMINYL overdosace. Intravenous atrooine sulphate titrated to effect is recommended at an initial dose of 0.5 to $1.0 \mathrm{mg} \mathrm{i} . \mathrm{v}$, with subsequent doses based upon clirical response. Atyical responses in blood pressure and heart rate have been reportec with other cholinomimetics when co-administered with quaternary anticholinergics. it is not known whether REMINYL and/or its metabolites can be removed by dalysis (hemodialysis, peritoneal dialysis, or hemofiltration). Dose-related signs of toxicity in animals included hypoactivity, tremors, clonic convulsions, salivation, lacrimation, chromodacryornea, mucoid feces, and dysprea 
REMIVYL (galantamine hydrobromide) tablets should only be prescribed by (or following consultation with) clinicians who are experienced in the diagnosis and management of Alzheimer's Disease.

Adults

The dosage of REMINYL shown to be effective in controlled clinical trials is $16-32 \mathrm{mg} / \mathrm{day}$ given as twice daily dosing. As the dose of $32 \mathrm{mg} /$ day is less well tolerated than lower doses and does not provide increased effectiveness, the recommended dose range is $16-24 \mathrm{mg} /$ day given in a b.i.d. regimen. The dose of $24 \mathrm{mg} /$ day did not provide a statistically significant greater clinical benefit than $16 \mathrm{mg} /$ day. It is possible, however, that a daily dose of $24 \mathrm{mg}$ of REMINYL might provide additional benefit for some patients.

The recommended starting dose of REMINYL is $4 \mathrm{mg}$ twice a day $(8 \mathrm{mg} /$ day). After a minimum of 4 weeks of treatment if this dose is well tolerated, the dose should be increased to $8 \mathrm{mg}$ twice a day $(16 \mathrm{mg} / \mathrm{day})$. A further increase to $12 \mathrm{mg}$ twice a day (24 mg/day) after a minimum of 4 weeks at the previous dose may be considered following appropriate assessment of clinical benefit and tolerability.

REMINYL should be administered twice a day, preferably with morning and evening meals.

Patients and caregivers should be warned that if therapy has been interrupted for several days or longer, the patient should be restarted at the lowest dose and the dose escalated to the current dose.

The abrupt withdrawal of REMINYL in those patients who had been receiving doses in the effective range was not associated with an increased frequency of adverse events in comparison with those continuing to receive the same doses of that drug. The beneficial effects of REMINYL are lost, however, when the drug is discontinued.

\section{Concomitant Treatment}

In patients treated with potent CYP206 or CYP3A4 inhibitors, dose reductions can be considered.

\section{Special Populations}

Dose escalation for elderly patients ( $>85$ years old) with low body weight (especially fermales) or serious comorbid diseases should be undertaken with particular caution

Hepatic impaiment

Galantamine plasma levels may be increased in patients with moderate to severe hepatic imparment. In patients with moderately impaired hepatic function (Child-Pugh score of 7-9), dosing could begin with 4 mg once daily for at least 1 week. Then the dosage should be increased to $4 \mathrm{mg}$ twice a day for at least 4 weeks. In these patients, daily doses should not exceed $8 \mathrm{mg}$ twice a day ( $16 \mathrm{mg} /$ day). Since no data are available on the use of REMNYL in patients with severe hepatic impaiment (Child-Pugh score of 10-15), REMINY is not recommended for this population (see PRECAUTIONS).

Renal impaiment

For patients with renal impairment (creatinine clearance of 9 to $60 \mathrm{~mL} / \mathrm{min}$ ). dose escalation should proceed cautiously and the maintenance dose should generally not exceed $16 \mathrm{mg} / \mathrm{day}$. Since no data are available on the use of REMINYL in patients with a creatinine clearance less than $9 \mathrm{~mL} / \mathrm{min}$, REMINYL is not recommended for this population (see PRECAUTIONS)

In a population of cognitively-impaired individuals, safe use of this and all other medications may require supervision.

\section{PHARMACEUTICAL INFORMATION}

Drug Substance

Trade Name:

Common Name:

Chemical Name:

Structural Formula:

Molecular Formula:

Molecular Weight:

Ionization Constant:

Partition Coefficient:

Description:
REMINYL

galantamine hydrobromide

$(4 \mathrm{a} S, 6 R, 8 \mathrm{a} S)-4 \mathrm{a}, 5,9,10,11,12$ hexahydro-3-methoxy-11-methyl-6Hbenzofuro(3a,3,2-eff[2] benzazepin-6-0] hydrobromide

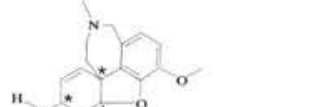

[4aS-(4aa,6b,8a月7)] Hydrobromide (1:1)

$\mathrm{C}_{1} \mathrm{H}_{4} \mathrm{NO} \cdot \mathrm{HBr}$

368.27

$\mathrm{pKa}=8.2$ (azepine moiety)

$\log P=1,09$, between $n-o c t a n o l$ and an aqueous buffer solution at $\mathrm{pH}=12.0$ $257.3^{\circ} \mathrm{C}$

Galantamine hydrobromide is a white to almost white powder It is freely soluble in water $(\mathrm{pH}=5.2), 0.1 \mathrm{~N}$ hyd (1) 1.0$)$ and $0.1 \mathrm{~N}$ sodium hydroxide $(\mathrm{pH}=8.3)$.

Composition

REMINYL (galantamine hydrobromide) tablets are available in three strengths containing $4,8,12 \mathrm{mg}$ of galantamine per tablet, as galantamine hydrobromide. The inactive ingredients are lactose monohydrate, microcrystalline celluslose, colloidal anhydrous silica, crospowidone, magnesium stearate, hydrownpropyl mettyicellulose, propylene glycol, taic, and titanium

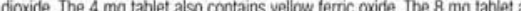
FD \& C yellow \#6 (also known as orange yellow $S$ aluminum lake).

Stability and Storage Recommendations

REMiNY tablets should be stored between $15^{\circ} \mathrm{C}-30^{\circ} \mathrm{C}$ AVAILABILITY OF DOSAGE FORMS

REMINYL (galantamine hydrobromide), expressed as galantamine base, is available as film-coated tablets in the following strengths:

$4 \mathrm{mg}$ tablets which are off-white, circular, biconvex tablets with the inscription IANSSEN" on one side and "G4" on the other side:

$8 \mathrm{mg}$ tablets which are pink, circular, bicorvex tablets with the inscription "JANSSEN" on one side and " $\mathrm{GB}$ " on the other side:

$12 \mathrm{mg}$ tablets which are orange-brown, circular, biconvex tablets with the inscription "JANSSEN" on one side and "G12" on the other side.

REMINML is avalable in bottles of 60 tablets and in blisters of 56 tablets per carton. Product Monograph available to healthcare professionals upon request.

\section{JANSSEN-ORTHO}

9 Green Belt Drive, Toronto, Ontario M3C 119

Date of Issuance: September 2003

RMP1031032A

(C) 2003 JANSSEN-ORTHO Inc

-All trademark rights used under license (RED PABE"

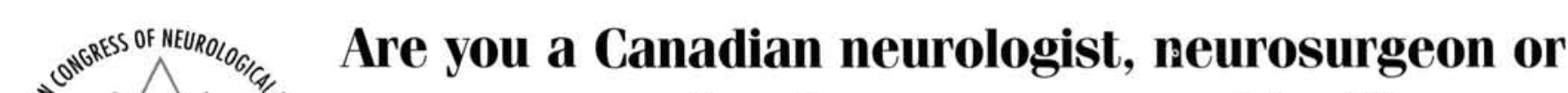 neurology/neurosurgery resident?}

\section{Then the Canadian Congress of Neurological Sciences (CCNS) has a member society for you! Join one of four member societies representing neurologists and neurosurgeons in Canada and receive these member benefits:}

- Canadian Journal of Neurological Sciences (CJNS) subscription, both print and online. CINS is a highly respected international neurological sciences medical journal. Check out the new Journal web site at www.cjns.org.

- Reduced registration fees for the annual scientific meeting, depending on membership category.

- The Annual Membership Directory, a handy reference tool

- Maintenance of Certification and Continuing Medical Education (CME) opportunities through the annual meeting. Watch for updates on new Journal-related CME.

- The CCNS newsletter Neuro News

- Access to grants, awards and fellowships (some are restricted to members)

- Residents and Fellows receive these benefits for a bargain-priced annual fee of \$35

The four member societies are:

- Canadian Neurological Society (CNS)

- Canadian Neurosurgical Society (CNSS)

$\downarrow$ Canadian Society of Clinical Neurophysiologists (CSCN)

$\downarrow$ Canadian Association of Child Neurology (CACN)

For membership information,

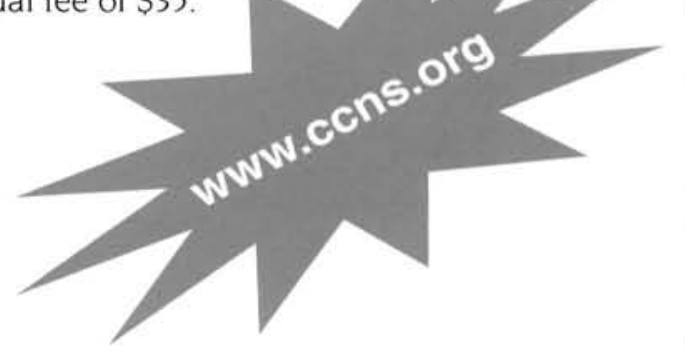

call us at (403) 229-9544; e-mail: brains@ccns.org or check out the CCNS web site at www.ccns.org 


\section{Axert $^{*}$}

\section{almotriptan malate tablets}

\section{${ }^{\text {PrAXERT* }}$ \\ almotriptan malate tablets \\ $6.25 \mathrm{mg}$ and $12.5 \mathrm{mg}$ \\ almotriptan \\ 5-HT, Receptor Agonist \\ Migraine Therapy}

ACTION AND CLINICAL PHARMACOLOGY

\section{Mechanism of Action}

AXERT (almotipiplan malate) is a selective 5 - hydroxytryptamine, receptors Am Antriptanl thas a weak affinity for $5-\mathrm{HT}_{1,}$ and $5-\mathrm{HT}$, receptors, but has

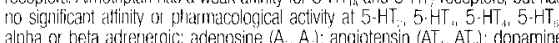

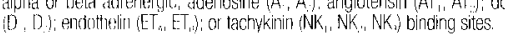
Current theorites on the etilology of migraine headaches suggest that symptoms are due to local cranial vasodilation andior to the release of vasoactive and proinitlammatory peptides troir the sensory nerve endings in an activated trigemina
system. The thesapeutic, activity of atmotriptan in migraine can most likely be

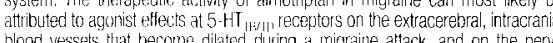
blood vessets that becomme dilated duling it migraine attack, and on the nerve
terminals in the trigeminal systerm. Activation of these receptors results in crania vessel consticition, inhibition of the neuropeptide release, and reduced transmission
in the trigemiral pant patthwers.

Pharmacokinetics

Absorption

Amotriptan is wall atsorbed following oral adtiristration. The mean oral absolute

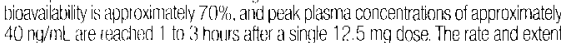
of absorptikn ale not atterted by toxd intake or by administration dusing a migraine of absorvition ale not atterted by tood intake or by administration dur

Distribution

Almotriptan is extensively distributed. Alnutriptan is minimally protein boun

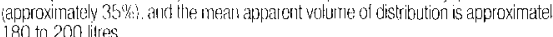
Metabolism

Amotiptan is metabolizod by one minor and two major pathways. Monoamine oxidase (MAO)-medinted trixidative deamination kapproximately $27 \%$ of the dose) and

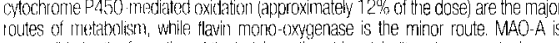

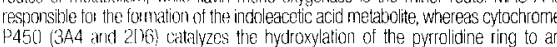
intermediale that is turt titer oxidized by aldehyde dehydrogentase to the gamma

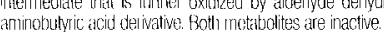

Excretion

The mean half life of almotiptan is between 3 and 4 hours. The primary route of elinirination is vian unal clearance. accounting for $75 \%$ of the administered dose Approximately $40 \%$ of an administered dose is excreted unchanged in urine, Rena

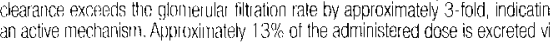
feces, bottr unchanged and metatbulized

\section{Special Populations}

Geriatric

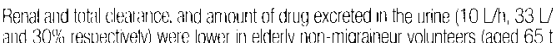
and $30 \%$ respectivelyy were. lower in elderly run-migraineur volunteers (aged 65 in longer termintal hat

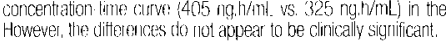

Pediatric

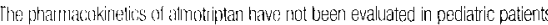
Gender

No sign ificant genden nifferencess have begn obsevved in pharmacakinetic parameter Race

No sinpificarth diffetences have becn observed in the pharmacokinetic parameters wetween Caucisian end Atrican Anlerican volunteers

Hepatic Impairment

The pharmacokinetiss of almotriotan heve? not been assessed in this population. Based on the known mechanisms of the charance of almotriptan, the maximum

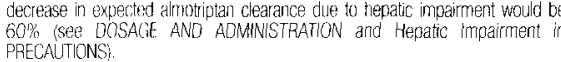
PRECALTIONS:

The clearance of almotiptan was aporoximately $65 \%$ lower in patients with severe

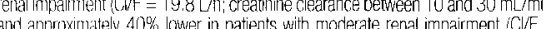

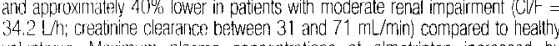

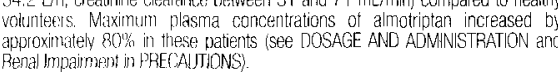

\section{CLINICAL STUDIES}

The phamacologicas activity of almotholath in

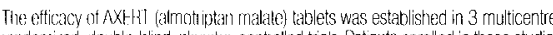

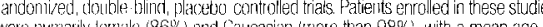

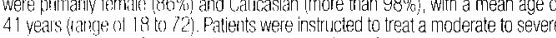
migraine headachle. lwo hours atter laking one dose of study medication, patients

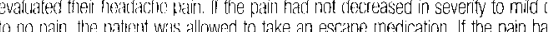
decreatsed to Inild ai lu no pair at 2 houlus but subsequently increased in severity between 2 and 24 hours, it was considered a relapse and the patent was instructed take a second dose of study medication. Associated symptoms of nausea,

In these studies, the percentage of patients achieving a response (mild or no pain) 2 hours atter treatment was significantly greater in patients who received eithe AXERT $6.25 \mathrm{mg}$ or $12.5 \mathrm{mg}$, compared with those who received placebo. In study 1. aimotriptan $12.5 \mathrm{mg}$ was superior to placebo as eafly as 30 minutes after diug eported pain relief after treatment with the $12.5 \mathrm{mg}$ dose than with the $6.25 \mathrm{~m}$ cose. Doses greater than $12.5 \mathrm{mg}$ did not lead to significantly better response

Table 1. Pain Relief Rates 2 Hours Following Treatment of Initial Headache

\begin{tabular}{|c|c|c|c|}
\hline & Placebo & $\begin{array}{l}\text { AXERT } \\
6.25 \mathrm{mg}\end{array}$ & $\begin{array}{c}\text { AXERT } \\
12.5 \mathrm{mg}\end{array}$ \\
\hline Study 1 & $\begin{array}{l}32.5 \% \\
(n=80)\end{array}$ & $\begin{array}{l}56.3 \% \%^{*} \\
(n=167)\end{array}$ & $\begin{array}{l}58.5 \%^{\dagger} \\
{[n=164)}\end{array}$ \\
\hline Study 2 & $\begin{array}{l}42,4 \% \\
(n=98)\end{array}$ & - & $\begin{array}{l}56.5 \% \%^{+1} \\
(\mathrm{n}=184)\end{array}$ \\
\hline
\end{tabular}

$\begin{array}{cccc}33.9 \% & 57.3 \% & 64.6 \% \\ (n=176) & (n=360) & (n=373) \\ \end{array}$

\section{$p$ value 0.002 in comparison to placebo}

p value $<0.001$ in comparison to placebo

hese results cannot be validly compared with results of anti-migraine treatments in other studies. Because studies are conducted at different limes, with ditterent samples of patients, by difterent investigators, employing different criteria and/o regimen, etc, , quantitative estimates of treatment responses and the timing o
responses may te expected to vary considerably from study to study.

For patients with migraine-associated photophobia, phonophobia, nausea, and vomiting at baseline, there was a decreased incidence

Two to 24 hours following the iritial dose of study medication, patents were allowed to take an escape medication or a second cose of study medicaton for pain groups than by those in the active almotriptan treatment groups.

The efficacy of AXERT was unaffected by the presence of aura; by gender, weight age of the patent, or oy concomitant use of common migraine prophylactic drug (e.g. beta-blockers, calcium channel blockers, tricycic antidepressents), or oral
contraceptives. There were insufiticient data to assess the effect of race on efficacy.

\section{INDICATIONS AND CLINICAL USE}

AXERT (almotriptan malate) tablets are indicated for the acute treatment of migraine with or without aurad in adults

AXERT is not intended for the prophylactic therapy of migraine or for use in the management of hemiplegic, ophthalmuplegic or basilar migraine isse established for custer headache, which presents in an older, predominantly male
population.

\section{CONIRAINDICATIONS}

AXERT (almotriptan malate) is contraindicated in patients with history symptoms, or signs of ischemic cardiac, cerebrovascular or periphera vascular syndromes, valvular heart disease or cardiac arrhythmias (especially tachycardias). In addition, patients with other signitican underlying cardiovascular diseases (e.g., atherosclerotic disease, syndromes include, but are not restricted to, angina pectoris of any type (e.g., stable angina of effort and vasospastic forms of angina such as the Prinzmetal's variant), all forms of myocardial infarction, and silent myocardial ischemia. Cerebrovascular syndromes include, but are not limited to, strokes of any type as well as transient ischemic attacks (TIAS). Peripheral vascular disease includes, but is not limited Because AXERT may increase blood pressure, it should not be given Because AXERT may increase blood pressure, it should not be
to patients with uncontrolled hypertension (see WARNINGS).

AXERT should not be administered within 24 hours of treatment with another 5-HT ${ }_{1}$ agonist, or an ergotamine-containing or ergot-type Axication, such as dihydroergotamine or methylsergide.

AXERT should not be given to patients with hemiplegic, ophthalmoplegic or basilar migraine.

AXERT is contraindicated in patients who are hypersensitive to almotriptan or any other ingredients in AXERT.

\section{WARNINGS}

AXERT (aimotriptan malate) tablets should only be used where a clear diagnosis of migraine has been established.

Risk of Myocardial Ischemia and/or Infarction and Other Adverse

Because of the potential of this class of compounds $\left(5-\mathrm{HT}_{1 \mathrm{~B} / 10}\right.$ agonists) to cause coronary vasospasm, AXERT should not be given to patients with documented ischemic or vasospastic coronary artery disease (see (including AXERT) not be given to patients in whom unrecognized (including AXERT) not be given to patients in whom unrecognized coronary artery disease (CAD) is predicted by the presence of risk factors such as: hypertension, hypercholesterolemia, smoker, obesity, physiological menopause, or male over 40 years of age, unless a cardiovascular examination provides satisfactory clinical evidence that the patient is reasonably free of coronary artery and ischemic myocardial disease or other significant underlying cartiovascular disease. The sensitivity of cardiac diagnostic procedures to detect cardiovascular diseases or predisposition to coronary artery vasospasm is modest at best. If, during the cardiovascular evaluation, the patient's medical history, electrocardiogram (ECG) or other evaluations reveal findings indicative of, or consistent with, coronary artery vasospasm, or
myocardial ischemia, AXERT should not be administered (see myocardial ischemia,

These evaluations, however, may not identify every patient who has cardiac disease, and in very rare cases, serious cardiac events, such as myocardial infarction or coronary ischemia have occurred in patients without evidence of underlying cardiovascular disease. For patients with risk factors predietive of CAD, who are determined to have a satisfactory cardiovascular evaluation, it is strongly recommended that administration of the first dose of AXERT take place in a clinical setting, such as the physician's office or a similarly staffed medical facility, unless the patient has previously received
almotriptan. Because cardiac ischemia can occur in the absence of any clinical symptoms, consideration should be given to obtaining an ECG during the interval immediately following the first use of AXERT in a patient with risk factors. However, an absence of drug-induced provar effects on the occasion of the initial dose does not preclude the possib

If symptoms consistent with angina occur after the use of AXERT, ECG evaluation should be carried out to look for ischemic changes.

It is recommended that patients who are intermittent long-term users of AXERT and who have or acquire risk factors predictive of CAD as described above undergo periodic interval cardiovascular evaluation as they continue to use AXERT.

The systematic approach described above is intended to reduce the likelihood that patients with unrecog

Gardiac Events and Fatalities Associated with 5- $\mathrm{HT}_{1}$ Agonists

Serious adverse cardlac events, including acute myocardial infarction have been reported within a few hours following administetion of almotriptan. Life-threatening disturbances of cardiac inythm and death have been repoted within a few hours following the administration of other $5-\mathrm{HT}$, agonists. Oue to the common the nature described below should be considered for all agents of this class. Considering the extent of use of 5-HT. agonists in patients with migraine, the incidence of these events is extrernely low.

AXERT can cause coronary vasospasm; at least one of these events occurred in a disease.

Patients with symptomatic Wolff-Parkinson-White syndrome or arrtythrrias associated with other carciac accossory conduction pathway disorders should no Premarketing experience with almotriptan

Among the 3865 subjects/patients who received AXERT in premarketing clinical thals, one patient was hospitalized for observation after a scheduled ECG was found to be abnormal (negative T-waves on the left leads) 48 hours after taking a singl. ther doses for earlier migraine attacks. Myocardial enzymes at the time of the abnornal ECG were normal. The patient was diagnosed as having had myocardia ischermia, and it was also found that she had a tarmily history of coronary disease,
An ECG performed 2 days later was normal, as was a follow-up coronary angiography. The patient recowered without incident.

Postmarketing experience with almotriptan

Serious cardiovascular events have been reponted in association with the use of AXERT. The uncontrolled nature of postmarketing survellance, however, makes it impossible to definitely determine the proportion of the reported cases that wer Cerebrovascular Events and Fatalities with 5- $\mathrm{HT}_{1}$ Agonists Cerebral hemorhage, subarachnoid hemorrhage, stroke and other cerebrovascular
events have been reourted in patients treated with other $5-\mathrm{HT}_{1}$ agonists, and some have resulted in fatalities. In a number of cases, it appears possible that the
cerebrovascular events were primary, the agonist having been administered in the belief that the symptoms experienced were a consequence of migraine, when they were not. It should be noted, however, that patents who suffer from migraine may have an increased risk of certain cered

Other Vasospasm-Related Events

5- $\mathrm{HT}_{\text {i }}$ agonists may cause vasospastic reactions other than coronary artery vasospasm. Both peripheral vascular ischernia and colonic ischemia with abdomina Increases in Blood Pressure

Significant elevations in systemic blood pressure, including hypertensive crisis, have been reported on rare occasions in patients with and without a history of hycertension
treated with other $5-\mathrm{HT}^{\mathrm{T}}$, agonists. AXERT is contraindicated in patients with treated with other $5-H_{1}$ agonists. AXERT is contraindicated in patients with

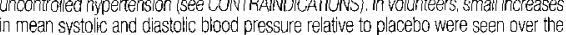
irst 4 hours after administration of $12.5 \mathrm{mg}$ of almotriptan $\langle 0.21$ and $1.35 \mathrm{~mm} H \mathrm{Hg}$, with hypertension controlled by medication. In this popuation, mean increases in systolis and diastolic blood nressure relatitye to placebo over the first 4 hours after administration of $12.5 \mathrm{mg}$ of alrnotiptan were 4.87 and $0.26 \mathrm{~mm} \mathrm{Hg}$, respectively. patients were not considered dinically significant (see ADVERSE REACTIONS and PRECAUTIONS)

Special Cardiovascular Pharmacology Studies With Another 5-HI, Agonist

Subjects (n=10) with suspected coronary attery disease under yoing angiograph a $5 . H T_{1}$ agonist at a subcutanecus dose of $1.5 \mathrm{mg}$ produced an $8 \%$ increase in
aortic blood ofessure, an $18 \%$ increase in pumonary artery blood pressure and an aortic blood pressure, an $18 \%$ increase in pumonary artery blood pressure, and an
$8 \%$ increase in systemic vascular resistance. In adddition, mild chest pain or tightness 8\% increase in systemic vascular resistance. In addition, mild chest pain or tightness
was reported by four subjects. Cinically significant increases in blood pressure were experienced by three of the subjects (two of whom aisc had chest pain/discomfort). and 1 had insignificant coronary artery disease.

n an additional study with this same drug, migraine patients ( $(n=35$ ) tree of cardiovasculdar disease were subjected to assessments of myocardial pertusion by positron emission tomography while receiving a subcutaneous $1.5 \mathrm{mg}$ dose in the absence of a migraine

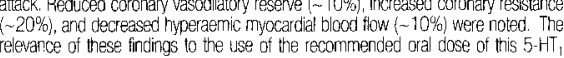
agonist is not known.

Sirnilar studies have not been done with AXERT. However, owing to the common oharmacodynamic actions of $5-\mathrm{HT}_{1}$ agonists, the possibility of cardiovascular effects of the nature described above should be considered for any agent of this pharmacological clas

Rare tyoersensitivity (anaghyaxis/sanaphylactoidy reactions have occurred in patients receiving other 5 -HT, agonists. Such yeactions can be ite threatening or tatal. in receving other $5-\mathrm{HT}_{1}$ agonilsts. Such reactions can be ife threatening of atal. In a history of sensitivity to multipe allergens. Owing to the possiblily of cross reactive

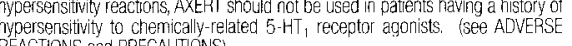

PRECAUTIONS

General

AXERT should be administered with cauton to patents with diseases that may aller the absorption, metabolism or excretion of drugs, such as those with impaired Populations and DOSAGE AND ADMINISTRATION)

\section{Cardiovaseular}

As with other $5-H T$, agonists, sensations of tighthess, pain, pressure, arid heavines: in the precordium, throat, neck and jaw have been reported after treatment with AXERT (almotriptan malate). These events have not been associated with
arrhythtmias or ischemic ECG changes in clinical trials. Because drugs in tris class, 
incuding AXERT, may cause coronary artery vasospasm, patients who experience signs or symptums sugaestive of angina following dosing should be evaluated tor
the presence of CAD or a predisposition to Prinzmetal's variant angina before eceiving additional doses of the medication, and shouid be monitored

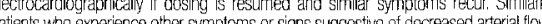

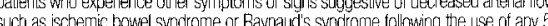
HT. agonist, ase candidates for further evaluation (SEe CONTRANDOCATONS and

\section{Neurologic Conditions}

Gare should be taken to exciude other potentially serious neuroboic conditions before treating headache in patients not previously diagnosed with migraine or who

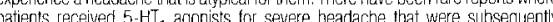

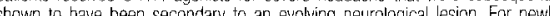
down to have besn secondany to an evalving neurabgical tesion. For newy migraine should be reconsidered it no response is seen after the first dose of Corneal Opacities

Three male cogs (out of a total of 14 treated) in a 52-week toxicity study of ora almotriptan ceveroped silght corneal opacities that were noted after 51, but not atter 25, weeks uf teatment he coses a which this 000 urred were 2,5 , and $12.5 \mathrm{mg} / \mathrm{kg} / \mathrm{da}$

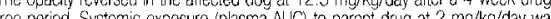

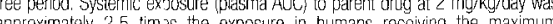

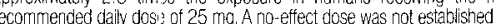

\section{Binding to Melanin-Containing Tissues}

When pigmented ads were given a single ora dose of $5 \mathrm{mg} / \mathrm{kg}$ of radiolabeled aimotriptan, the elirnination half-lffe of racioactivity from the eye was 22 days suggesting that almotriptan and/or its metabolites may bind to the melanin of the eye. Because almotnptan could accumulate in the melanin-nich tissues over time there is the possibility that it could cause toxicity in these tissues over extended use However, no adverse ocular effects related to treatment with almotriptan were noted in any of the toxicity studies. Althlough no systernic monitoring of aphthalmic function monitoring are offered, prescribers stousd be aware of the possibility of long-term ophthalmic effects.

\section{Carcinogenesis}

he carcinogenic potental of almotriptan was evaluated by oral gavage for up to 103 weeks in mice at doses of up to $250 \mathrm{mo} / \mathrm{kg} / \mathrm{day}$, and in rats for up to 104 weeks a doses up to $75 \mathrm{mg} / \mathrm{kg} / \mathrm{day}$. These doses were associated with plasma exposures (AUC) to parent drug that were approximately 40 and 78 times, in mice and rats resoect vely, the plasma AUC observed in humans receiving the MRDD of $25 \mathrm{mg}$.
Because of high motality rates in both studies, which reached statistical significance Because of high mottality rates in bath studies, which reached statistical significance were terminated between weeks 96 and 98 . There was no increase in tumors velated to almolriptan adrininistration.

\section{Mutagenesis}

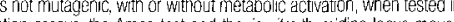

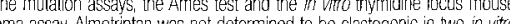
ymphona assay. Almotriptan was not determined to ve clastogenic in two in vito cytogenetics assays in human lymohocytes and an in wivo mouse micionicleas cytogenetics assays in human lymphocytes.

\section{mpairment of Fertility}

When temale rats received almotriotan by oral gavage prior to and during mating and up to implantation at doses of 25, 100, and $400 \mathrm{mg} / \mathrm{kg} /$ day, prolongation of the estrous cycle was observed at a duse of $100 \mathrm{mg} / \mathrm{kg}$ / $\mathrm{day}$ (exposure, based on mgrm, was approximately 40 times exposure in humans receiving the maximum emale rats at $25 \mathrm{mg} / \mathrm{kg}$ /day (exposure aporoximately 10 times human exposure at MRDC). No adverse effects were noted in male rats at $400 \mathrm{mg} / \mathrm{kg} / \mathrm{day}$ (160 imes the human exposure based on $\mathrm{mo} / \mathrm{m}$ ?

\section{Pregnancy}

When almotriptan was administered orally during organogenesis to pregnant rats at doses of $125,250,500$ and $1000 \mathrm{mg} / \mathrm{kg} /$ day, an increase in embryolethality was seen at the $1000 \mathrm{mg} / \mathrm{kg} / \mathrm{day}$ dose (maternal exposure Ibased on plasma AuC of parent drugl was approximately 958 times the human exposure at MRDD of 25 noted at doses greater than the no- observed-effect level in rats of $125 \mathrm{mg} / \mathrm{kg} / \mathrm{day}$ (maternal exposure 80 times human exposure at MRDD). Similar studies in rabbits creases in em aryotiptan at doses of 5,20 and $60 \mathrm{ing} / \mathrm{kg} / \mathrm{day}$ ased on $\mathrm{mg} / \mathrm{m}$ 50 tmes human exoos ure at MRDD. When almotriptan was administered to rats troughout the periods of gestation and lactation at doses of 25, 100 and 400 $m \mathrm{~m} / \mathrm{kg} / \mathrm{day}$, gestation length was increased and litter size and ottspring body weight
were decreased at the high dose (matemal exposure, based on $\mathrm{mg} / \mathrm{m}^{2}, 160$ times human exonSure at MFODh. The decrease in pup weight persisted throughout
lactation. The no-observed-effect level in this stury was $100 \mathrm{mg} / \mathrm{kg} / \mathrm{day}$ (maternal lactation. The no-observed-effect level in this stury

There have been no adequate and well-controlled studies in pregnant women heretore AXERT should only be used during pregnancy if the potential beneft ustifies the risk to the fetur

AXERT should be used with caution in patients with hepatic impairment. The maximum dally dose should not exceed $12.5 \mathrm{mg}$ over a 24 -hour period, and a starting dose of $6.25 \mathrm{mg}$ is recommended (SEe ACTION AND CLINIC
PHARMACOLOGY, Special Populations and DOSAGE AND ADMINISTRATION).

\section{Renal Impairment}

XERT should be used with caution in patients with severe renal impairment. The maximum daly dose should not exceed $12.5 \mathrm{mg}$ over a 24 -hour period, and starting dose of $6.25 \mathrm{mg}$ should be used (SEe ACTICN AND CLINICAL

\section{Psychomotor Effect}

atients should be advised to avoid driving a car or operating hazardous machiner until they are reasonably certain that AXERT does not affect thern adversely

\section{Use in the Elderly}

Winical studies of AXERT did not include sufficient numbers of subjects over 65 years of age to determine whether they respond differently from youriger subjects Renal and total clearance, and amount of drug excreted in the urine were lower in migraineur vol unteers lage 19 to 34 years?, resulting in longer terminal half- -lfe and higher area unider the plasma concentration-time curve, Although clearance of almotrinta') was lower in elderly vounteers, there were no difterences in the satety and tolerability between the two populations (see ACTION AND CLINICAL
PHARMACOL OGY Special Populations). In general, dose selection for an elderly patient should be cautious, usualy starting at the low end of the dosing range efflecting the greater frequency of decreased renal, cardiac, and hepatic function and of concomitant disease or other drug therapy.

\section{Use in Children}

The safety and effectiveness of AXERT in pediatric patienłs has not been years of age

Post-marketing experience with other triptans include a limited number of reocrts that describe pediatric (under 12 years of age) and adolescent $112-17$ years in natule to those reported as rare occurrences in aduts

\section{Use during Lactatio}

Is not known whether amotriptan is excreted in human milk. Since many drugs are excreted in human milk, caution should be exercised when AXERT Dependence Liability

Although the abuse potential of AXERT has not been specifically assessed, no abuse ut, tolerance to, withcrawal from, or drug-seeking behaviour was observed in patients who received AXERT in chinical trials or their extensions. The 5 HT agonists, as a class, have not been associated with drug abuse

\section{Drug Interactions}

All drug interaction studies were pefformed in healthy volunteers using a single 12 ming dose of almotriptan and multiple doses of the other orug.

Ergot-containing drugs

hese crugs have been reported to calse prolonged vasospastic reactions. As theer a theoretical basis that these effects may be additive, use of ergotamine AXERT within 24 hours of each other should be avoided isee
AXnting CONTRAINDICATIONS).

Monoamine cxidase inhibitors

Coadministration of almotriptan and modobemide $1150 \mathrm{mg}$ b.i.d. for 8 days approximately $6 \%$. No dose adjustment is necessary.

Propranolol

Coadministration of aimotriptan and propranolol (80 $\mathrm{mg}$ b.i.d. for 7 days) resulted in пo significant changes in the pharmacokinetics of almotriptan.

Selective serotonin reuptake inhibitors (SSRIs)

Coadministration of almotriptan and fluoxetine (60 $\mathrm{mg}$ daily for 8 days), a potent Thibitor of CYP2D6, had no effect on almotriptan ciearance, but maxim scrificant. SSPF rarely reported to cause weakress, axper aroxetne, sertame) have been coadministered with 5-HT, agonists. If concomitant treatment with AXERT and an SSHI is clinically warranted, approprate observation of the patient, for both acute and long term adverse events, is advised.

Verapamil

Cadministration of amotriptan and veraparnil $120 \mathrm{mg}$ sustained-release tablets under the plasma concentration-time curve and in a $24 \%$ increase in me arease in maxima plasma concentations of almotriptan. Neither of these chances is clinicaly significan Other $5-\mathrm{HT}_{\mathrm{BB} / 10 \text {. } 2 \text { gonists }}$

Concomitant use of other $5 \cdot \mathrm{HT}_{18 \text { in }}$ agonists within 24 hours of treatment with

Ketoconazole and other notent CYP3A4 inhibitor

Coadministration of ammotiptan and the potent CYP3A4 inhibitor ketoconazole (400 mig q.d. for 3 daysj resulted in an approximately $60 \%$ increase in the area unde the plasma concentration-time curve and maximal plasma concentrations of almotriptan. Although the interaction between almotriptan and other potent CYP3AA inhibitors (e.g, itraconazole, ritonavir, and erythromyciny has not been studied
increased exposures to almotriptan may be expected when almotriptan is used concomitantly with the

Almotriptan is not known to interfere with any commonly employed clinica acoratory

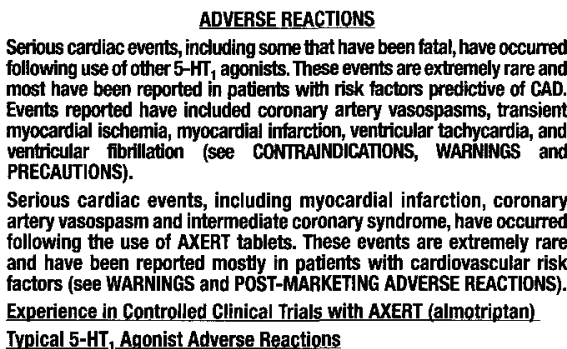

\section{Typical 5-HT, Agonist Adverse Reactions}

As with other $5-\mathrm{HT}_{1}$ agonists, AxERT has been associated with sensalions any part of the body including the chest, throat, neck, jaw and upper limbs

\section{Increases in Blood Pressure}

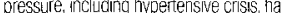
been reported on rare occasions in patients with and without a history o hypertension treated with other $5 \cdot H$ H, agonists. AXERT is contraindicated in patients with uncontrolled hypertension (see CONTRANDICATIONS). In volunteers, sma increases in mean systolic and diastalic blood pressure relative to placebo were $1.35 \mathrm{~mm}$ Hg, respectively). The effect of AXERT on blood pressure was also mean increases in systolic and diastolic blood pressure relative to placebo over the first 4 hours atter administration of $12.5 \mathrm{mg}$ of almotriptan were 4.87 and $0.26 \mathrm{~mm}$ $\mathrm{Hg}$, respectively. The slight increases in blood pressure in both volunteers and Controlled hypertensive patients were no

\section{Acute Safety}

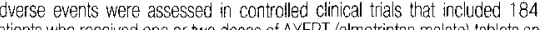
patients who received one or two doses

The most common adverse events during treatment with AXERT were nausea somnolence, headache, paresthesia, and dry mouth. In long-term, open-labe studies where patients were allowed to treat mutiple attacks for up to one yea Table 2 ists the adverse events that occurred in at least $1 \%$ of the patients treated with AXERT, and at an incidence greater than in patients treated with placebo regardless of drug relationship. These events reflect experience gained under closely monitored conditions of clinical trials in a highly selected patient population. In actual cinical practice or in other clinical trials, these frequency estimates may
not apoly as the conditions of use, reporting behaviour, and the kinds of patients not apply, as the cond
treated may differ 


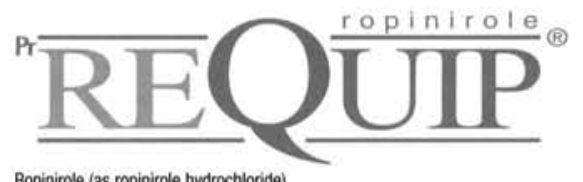

Ropinirole (as ropinirole hydrochloride)

TABLETS: $0.25 \mathrm{mg}, 1.0 \mathrm{mg}, 2.0 \mathrm{mg}, 5.0 \mathrm{mg}$

THERAPEUTIC CLASSIFICATION: AntiParkinsonian Agent / Dopamine Agonist INDICATIONS AND CLINICAL USE: REQUIP" (ropinirole hydrochloride) is indicated in the treatment of the signs and symptoms of idiopathic Parkinson's disease. REQUIP* can be used both as early therapy, without concomitant levodopa and as an adjunct to levodopa. Three year and five year activecomparator controlled clinical trials have been conducted.

CONTRAINDICATIONS: REQUIP" (ropinirole hydrochloride) is contraindicated in patients with a known hypersensitivity to ropinirole hydrochloride or the excipients of the drug product.

WARNINGS: Sudden Onset of Sleep - Patients receiving treatment with REQUIPs (ropinirole hydrochloride), and other dopaminergic agents have reported suddenly falling asleep while engaged in activities of daily living. including operating a motor vehicle, which has sometimes resulted accidents. Although some of the patients reported somnolence while on REQUIP", others perceived that they had no warming signs, such as excessive drowsiness, and believed that they were alert immediately prior to the event. Physicians should alert patients of the reported cases of sudden onset of sleep, bearing in mind that these events are NOT limited to initiation of therapy. Patients should also be advised that sudden onset of sleep has occurred without warning signs. If drowsiness or sudden onset of sleep should occur, patients should immediately contact their physician. Until further information is avaliable on the management of this unpredictable and serious adverse event, patients should be warned not to drive or engage in other activities where impaired alertness could put themselves and others at risk of serious injury or death (e.g. operating machines). Episodes of falling asleep while engaged in activities of daily living have also been reported in patients taking other dopaminergic agents, therefore, symptoms may not be alleviated by substituting these products. Presently, the precise cause of this event is unknown. It is known that many Parkinson's disease patients experience alterations in sleep architecture, which results in excessive daytime sleepiness or spontaneous dozing, and that dopaminergic agents can also induce sleepiness. There is insufficient information to determine whether this event is associated with REQUIP", all dopaminergic agents or Parkinson's diseas itself. Orthostatic Symptoms - Dopamine agonists appear to impair the systemic regulation of blood pressure with resulting orthostatic symptoms of dizziness or lightheadedness, with or without documented hypotension. These symptoms appear to occur especially during dose escalation. Therefore, patients treated with dopamine agonists should be carefully monitored for signs and symptoms of orthostatic hypotension, especially during dose escalation (see DOSAGE and ADMINISTRATION) and should be informed of this risk. Hallucinations - Early Therapy: In placebo- controlled trials, REQUIP (ropinirote hydrochloride) caused hallucination in $5.1 \%$ of patients during early therapy (1.4\% in the placebo group). Hallucination was of sufficient severity that it led to discontinuation in $1.3 \%$ of patients. The incidence of hallucination was dose-dependent. In a 5-year study comparing REQUIPe with levodopa in early Parkinson's patients, the overall incidence of hallucinations was $17.3 \%$ (31/179) for patients treated with REQUIP" and $5.6 \%(5 / 89)$ for levodop patients. Hallucinations led to discontinuation of the study treatment in $5.0 \%$ of REQUIP" and $2.2 \%$ of levodopa patients. In a 3-year study comparing REQUIP" with another dopamine agonist, the overall incidence of hallucinations was $9.5 \%(16 / 168)$ for patients treated with REQUIP" and $9.0 \%$ (15/167) for patients receiving active comparator. Hallucinations led to discontinuation of the study treatment in $2.4 \%$ of REQUIP" patients and $3.0 \%$ of comparator patients. Concomitant Selegiline: In a 5-year study, REOUIP" patients receiving concomitant selegiline reported a higher incidence of hallucinations $(23.5 \%)$ than did those without $(12.2 \%)$; this subpopulation effect was not seen in the L-dopa arm (hallucinations with concomitan selegiline $=2.0 \%$ vs hallucinations without selegiline $=8.0 \%$, Adjunct Therapy: Hallucinations were experienced by $10.1 \%$ of patients receiving REQUIP" and levodopa, compared to $4.2 \%$ receiving placebo and levodopa. Hallucinations were of sufficient severity that it led to discontinuation in $1.9 \%$ of patients. The incidence of hallucinations was dose dependent. PRECAUTIONS: Cardiovascular - Since REQUIPe (ropinirole hydrochloride has not been studied in patients with a history or evidence of significant cardiovascular disease including myocardial infarction, unstable angina, cardiac decompensation, cardiac arrhythmias, vaso-occlusive disease (including cerebral) or cardiomyopathy, it should be used with caution in such patients. There is limited experience with REQUIPe in patients treated with anthypertensive and antiarnhythmic agents. Consequently, in such patients, the dose of REQUIP" should be titrated with caution. Orthostatic Symptoms Orthostatic symptoms of dizziness or lightheadedness as well as somnolence may occur during REQUIPo therapy. Neuroleptic Malignant Syndrome - A symptom complex resembling the neuroleptic malignant syndrome (characterized by elevated temperature, muscular rigidity, altere consciousness, and autonomic instability), with no other obvious etiology, has been reported in association with rapid dose reduction, withdrawal of, or changes in anti-Parkinsonian therapy. A single spontaneous report of a symptom complex resembling the neuroleptic malignant syndrome has been observed in a 66 year old diabetic male patient with Parkinson's disease, who developed fever, muscle stiffness, and drowsiness 8 days after beginning REQUIP" treatment The patient also experienced acute bronchitis, which did not respond to antibiotic treatment. REQUIP" was discontinued three days before the patient died. The reporting physician considered these events to be possibly related to REOUIPः treatment. (see DOSAGE AND ADMINISTRATION. A single spontaneous report of severe muscle pain has been reported in a 66 year old male patient around his thigh. The reporting physician considered the event to be probably related to REQUIPo treatment. Retinal Pathology in Rats - In a two year carcinogenicity study in albino Sprague-Dawley rats, retina atrophy was observed at incidences of $0 \%, 1.4 \%, 1.4 \%$ and $10 \%$ of male rats and $0 \%, 4.4 \%, 2.9 \%$ and $12.9 \%$ of female rats dosed at $0,1.5,15$ and $50 \mathrm{mg} / \mathrm{kg} /$ day respectively. The incidence was significantly higher in both male and female animals dosed at $50 \mathrm{mg} / \mathrm{kg} / \mathrm{day}$. The $50 \mathrm{mg} / \mathrm{kg} /$ day dose represents a 2.8 fold greater exposure (AUC) and a 13.1 fold greater exposure $\left(C_{m}\right)$ to ropinirole in rats than the exposure would be in humans at the maximum recommended dose of $24 \mathrm{mg} /$ day. The relevance of this finding to humans is not known. Pregnancy - The use of REQUIPs during pregnancy is not recommended. REQUIPs given to pregnant rats during organogenesis (gestation days 8 through 15) resulted in decreased fetal body weight at $60 \mathrm{mg} / \mathrm{kg}$ /day (approximately $3-4$ times the AUC at the maximal human dose

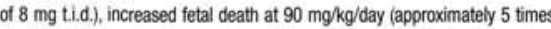
the AUC at the maximal human dose of $8 \mathrm{mg}$ ti.d.) and digital malformations at $150 \mathrm{mg} / \mathrm{kg} / \mathrm{day}$ (approximately $8-9$ times the AUC at the maximal human dose of $8 \mathrm{mg}$ ti.d.). These effects occurred at maternally toxic doses. There was no indication of an effect on development of the conceptus at a maternally toxic dose of $20 \mathrm{mg} / \mathrm{kg} /$ day in the rabbit. In a perinatal-postnatal study in rats, $10 \mathrm{mg} / \mathrm{kg} /$ day of REQUIPe (approximately $0.5-0.6$ times the AUC at the maximal human dose of $8 \mathrm{mg}$ t.i.d.) impaired growth and development of nursing offspring and altered neurological development of female offspring Nursing Mothers - Since REQUIPe suppresses lactation, it should not be administered to mothers who wish to breast-feed infants. Studies in rats have shown that REQUIP" and/or its metabolites cross the placenta and are excreted in breast milk. Consequently, the human fetus and/or neonate may be exposed to dopamine agonist activity. Use in Women Receiving Estrogen Replacement Therapy- In female patients on long-term treatment with coniugated estrogens, oral clearance was reduced and elimination half-life prolonged compared to patients not receiving estrogens. In patients, already receiving estrogen replacement therapy, REQUIP" may be titrated in the recommended manner according to clinical response. However, if estrogen replacement therapy is stopped or introduced during treatment with REQUIP" adjustment of the REQuIPe dosage may be required. Pediatric Use - Safety and effectiveness in the pediatric population have not been established. Rena and Hepatic Impairment - No dosage adjustment is needed in patients with mild to moderate renal impairment (creatinine clearance of 30 to $50 \mathrm{~mL} / \mathrm{min}$ ). Because the use of REQUIP" in patients with severe renal impairment or hepatic impairment has not been studied, administration of REQUIP" to such patients is not recommended. Drug Interactions - Psychotropic Drugs. Neuroleptics and other centrally active dopamine antagonists may diminish the effectiveness of REQUIP". Therefore, concomitant use of these products is not recommended. Based on population pharmacokinetic assessment, no interaction was seen between REQUIP" and tricyclic antidepressants of benzodiazepines. Anti-Parkinson Drugs: Based on population pharmacokinetic assessment, there were no interactions between REQUIP and drugs commonly used to treat Parkinson's disease, i.e., selegiline, amantadine, and anticholinergics. Levodopa: The potential pharmacokinetic interaction of levodopa/ carbidopa ( $100 \mathrm{mg} / 10 \mathrm{mg}$ b.i.d.) and REQUIPs ( $2 \mathrm{mg}$ ti.d.) was assessed in levodopa naive (de novo) male and female patients with Parkinson's disease ( $n=30$, mean age 64 years). The rate and extent of availability of REQUIPe at steady state were essentially the same with of without levodopa. Similarly, the rate and extent of availability of levodopa, as well as its elimination half-life, were essentially the same in the presence an absence of REQUIP". Inhibitors of CYP1A2: Ciprofloxacin: The effect of ciprofloxacin ( $500 \mathrm{mg}$ bid) on the pharmacokinetics of REQUIPs (2 mg ti.d) was studied in male and female patients with Parkinson's disease $(n=12$ mean age 55 years). The extent of systemic availability of REQUIP" was significantly increased when coadministered with ciprofloxacin (AUC increased by 1.84 fold). Thus, in patients already receiving CYP1A2 inhibitors such as ciprofloxacin, REQUipo therapy may be instituted in the recommended manner and the dose titrated according to clinical response. However, if therapy with a drug known to be an inhibitor of CYP1A2 is stopped or introduced during treatment with REQUIPs, adjustment of the REQUIP" dosage will be required Substrates of CYP1A2: Theophylline: The effect of oral theophylline $(300 \mathrm{mg}$ b.i.d) on the pharmacokinetics of REQUIP* (2 mg ti.d.) was studied in male and female patients with Parkinson's disease ( $n=12$, mean age 59 years). There was no marked change in the rate or extent of availability of REQUIP" when coadministered with theophylline. Similarly, coadministration of REQUIP" with intravenous theophylline $(5 \mathrm{mg} / \mathrm{kg})$ did not result in any marked change in the pharmacokinetics of theophylline. It is therefore unlikely that substrates of CYP1A2 would significantly alter the pharmacokinetics of REQUIP", and vice-versa. Digoxin: The effect of REQUIPo $(2 \mathrm{mg}$ ti.d.) on the pharmacokinetics of digoxin $(0.125-0.25 \mathrm{mg}$ 0.d.) was studied in male and female patients with Parkinson's disease ( $n=10$, mean age 72 years). Coadministration at steady state with REQUIP* resulted in a $10 \%$ decrease in digoxin AUC although mean trough digoxin plasma concentrations were unaltered. However, the effect of higher recommended doses of REQUIPs on the pharmacokinetics of digoxin is not known. Alcohol: No information is available on the potential for interaction between REQUIP" and alcohol. As with other centrally active medications, patients should be cautioned against taking REQUIP" with alcohol. Psycho-Motor Performance - (see WARNINGSSudden Onset of Sleep

ADVERSE REACTIONS: Adverse Reactions Associated with Discontinuation of Treatment - Of 1599 patients who received REQUIP (ropinirole hydrochloride) during the premarketing clinical trials, $17.1 \%$ in early-therapy studies and $17.3 \%$ in adjunct-therapy studies discontinued treatment due to adverse reactions. The events resulting in discontinuation of REQUIPo in $1 \%$ or more of patients were as follows: Early therapy: nausea $(6.4 \%)$, dizziness $(3.8 \%)$, aggravated Parkinson's disease $(1.3 \%)$, hallucination $(1.3 \%)$, headache $(1.3 \%)$, somnolence $(1.3 \%)$ and vomiting $(1.3 \%)$. Adjunct therapy: dizziness $(2.9 \%)$, dyskinesia $(2.4 \%)$, confusion $(2.4 \%)$, vomiting $(2.4 \%)$, hallucination $(1.9 \%)$, nausea $(1.9 \%)$, anxiety $(1.9 \%)$, and increased sweating $(1.4 \%)$. Patients over 75 years of age $(n=130)$ showed slightly higher incidences of withdrawal due to hallucination, confusion and dizziness thar patients less than 75 years of age. Most Frequent Adverse Events - Adverse events occurring with an incidence of greater than, or equal to, $10 \%$ were as follows: Early therapy: nausea, dizziness, somnolence, headache, peripheral edema, vomiting, syncope, fatigue and viral infection. Adjunct therapy: dyskinesia, nausea, dizziness, somnolence and headache. Dopamine agonists, with an ergoline chemical structure have been associated with adverse experiences such as retroperitoneal fibrosis, erythromelalgia and pulmonary reactions. REQUIP" has a novel, non-ergoline chemical structure and no reports of such events have been observed in clinical trials. Incidence of Adverse Events in Placebo Controlled Trials - The incidence of postura hypotension, an event commonly associated with initiation of dopamine agonist therapy, was not notably different from placebo in clinical trials However, decreases in systolic blood pressure to $<90 \mathrm{mmHg}$ have been observed in $13 \%$ ( $<65$ years), $16 \%$ ( $65-75$ years) and $7.6 \%$ ( $>75$ years) of patients treated with REQUIPs". Table 2 lists adverse events that occurred at an incidence of $1 \%$ or more among REQUIPe-treated patients who participated in placebo-controlled trials for up to one year. Patients were dosed in a range of $0.75 \mathrm{mg}$ to $24 \mathrm{mg} /$ day. Reported adverse events were classified using a standard World Health Organization (WHO)-based dictionary terminology. The prescriber should be aware that these figures can not be used to predict the incidence of adverse events in the course of usual medical practice where patient characteristics and other factors differ from those which prevailed in the clinical trials. Similarly, the cited frequencies can not be compared with figures obtained from other clinical investigations involving different treatments, uses and investigators. The cited figures, however, do provide the prescribing physician with some basis for estimating the relative contribution of drug and non-drug factors to the adverse events incidence rate in the population studied.

\begin{tabular}{|c|c|c|c|c|}
\hline \multicolumn{5}{|c|}{$\begin{array}{l}\text { TABLE } 2 \\
\text { Adverse events with incidence 21\% from al placebo-controlled } \\
\text { early and adjunct therapy studies }\end{array}$} \\
\hline & \multicolumn{2}{|c|}{ Earty Therapy } & \multicolumn{2}{|c|}{ Adjunet Therapy } \\
\hline & $\begin{array}{l}\text { REQUip" } \\
N=157 \\
\text { Soccurrence }\end{array}$ & 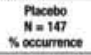 & 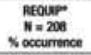 & 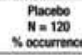 \\
\hline \multicolumn{5}{|c|}{ Autonomic Nervous System } \\
\hline Sweating Increased & 6.4 & 4.1 & 7.2 & 1.7 \\
\hline Mouth Dry & 5.1 & 3.4 & 5.3 & 0.8 \\
\hline Flushing & 3.2 & 0.7 & 1.4 & 0.8 \\
\hline \multicolumn{5}{|l|}{ Body as a Whole General } \\
\hline Peripheral Edema & 13.4 & 4.1 & 3.9 & 2.5 \\
\hline Fatigue & 10.8 & 4.1 & - & - \\
\hline Injury & - & - & 10.6 & 9.2 \\
\hline Pain & 7.6 & 4.1 & 5.3 & 3.3 \\
\hline Asthenia & 6.4 & 1.4 & - & - \\
\hline Orug Level Increased & 4.5 & 2.7 & 6.7 & 3.3 \\
\hline Chest Pain & 3.8 & 2.0 & - & - \\
\hline Malaise & 3.2 & 0.7 & 1.4 & 0.8 \\
\hline \multicolumn{5}{|l|}{ Therapeutic Response } \\
\hline Decreased & 1.9 & 0.7 & - & - \\
\hline Cellulitis & 1.3 & 0.0 & - & - \\
\hline Influenza-like Symptoms & - & - & 1.0 & 0.0 \\
\hline Fever & - & - & 1.4 & 0.0 \\
\hline \multicolumn{5}{|l|}{ Cardiovascular General } \\
\hline Syncope & 11.5 & 1.4 & 2.9 & 1.7 \\
\hline Hypotension Postural & 6.4 & 4.8 & - & - \\
\hline Hypertension & 4.5 & 3.4 & 3.4 & 3.3 \\
\hline Hypotension & 1.9 & 0.0 & 2.4 & 0.8 \\
\hline Cardiac Failure & - & - & 1.0 & 0.0 \\
\hline \multicolumn{5}{|c|}{ Central and Peripheral Nervous System } \\
\hline Dizziness & 40.1 & 21.8 & 26.0 & 15.8 \\
\hline Dyskinesia & - & - & 33.7 & 12.5 \\
\hline Headache & 17.2 & 17.0 & 16.8 & 11.7 \\
\hline Ataxia (Falls) & - & - & 9.6 & 6.7 \\
\hline Tremor & - & - & 6.3 & 2.5 \\
\hline Paresthesia & - & - & 5.3 & 2.5 \\
\hline Hyperesthesia & 3.8 & 20 & - & - \\
\hline Dystonia & - & - & 4.3 & 4.2 \\
\hline Hypokinesia & - & - & 5.3 & 4.2 \\
\hline Paresis & - & - & 2.9 & 0.0 \\
\hline Speech Disorder & $=$ & - & 1.0 & 0.0 \\
\hline Vertigo & 1.9 & 0.0 & - & - \\
\hline Carpal Tunnel Syndrome & 1.3 & 0.7 & - & - \\
\hline \multicolumn{5}{|l|}{ Gastrointestinal System } \\
\hline Nausea & 59.9 & 21.8 & 29.8 & 18.3 \\
\hline Vomiting & 12.1 & 6.8 & 7.2 & 4.2 \\
\hline Dyspepsia & 9.6 & 4.8 & - & - \\
\hline Constipation & 8.3 & 7.5 & 5.8 & 3.3 \\
\hline Abdominal Pain & 6.4 & 2.7 & 8.7 & 7.5 \\
\hline Diarthea & - & - & 4.8 & 2.5 \\
\hline Anorexia & 3.8 & 1.4 & - & - \\
\hline Flatulence & 2.5 & 1.4 & 1.9 & 0.8 \\
\hline Tooth Disorder & 1.9 & 0.7 & 1.0 & 0.8 \\
\hline Saliva Increased & - & - & 2.4 & 0.8 \\
\hline Colitis & 1.3 & 0.0 & . & - \\
\hline Dysphagia & 1.3 & 0.0 & 2.4 & 0.8 \\
\hline Periodontitis & 1.3 & 0.0 & 1.4 & 0.8 \\
\hline Eructation & - & - & 1.4 & 0.0 \\
\hline Fecal incontinence & - & - & 1.0 & 0.0 \\
\hline Hernornhoids & - & - & 1.0 & 0.0 \\
\hline Gastroesophageal Reflux & - & - & 1.0 & 0.0 \\
\hline Gastrointestinal Disorder (NOS) & s) - & - & 1.0 & 0.0 \\
\hline Tooth Ache & - & - & 1.0 & 0.0 \\
\hline \multicolumn{5}{|l|}{ Hearing and Vestibular } \\
\hline Tinnitus & 1.3 & 0.0 & - & - \\
\hline \multicolumn{5}{|l|}{ Heart Rate and Rhythm } \\
\hline Palpitation & 3.2 & 2.0 & 2.9 & 2.5 \\
\hline
\end{tabular}




\begin{tabular}{|c|c|c|c|c|}
\hline & \multicolumn{2}{|c|}{ Eanly Tharapy } & \multicolumn{2}{|c|}{ Adjunct Therapy } \\
\hline & $\begin{array}{c}\text { REQuipo } \\
N=157 \\
\% \text { occurrencece }\end{array}$ & $\begin{array}{c}\text { Placelho } \\
N=147 \\
\% \text { ofcurrence }\end{array}$ & $\begin{array}{c}\text { REQUNP } \\
\mathrm{N}=208 \\
\% \text { occurrence }\end{array}$ & $\begin{array}{c}\text { Placebo } \\
\mathrm{N}=120 \\
\% \text { occurrence }\end{array}$ \\
\hline \multicolumn{4}{|l|}{ Heart Rate and Rhythm } & \\
\hline $\begin{array}{l}\text { Extrasystoles } \\
\text { Tachycardia }\end{array}$ & $\begin{array}{l}1.9 \\
1.9\end{array}$ & 0.0 & $\overline{1.0}$ & 0.0 \\
\hline Fibrillation Atrial & 1.9 & 0.0 & - & - \\
\hline Tachycardia Supraventricular & 1.3 & 0.0 & - & - \\
\hline Bradycardia & - & - & 1.0 & 0.0 \\
\hline \multicolumn{5}{|l|}{ Liver and Biliary System } \\
\hline Gamma - GT Increased & 1.3 & 0.7 & 1.0 & 0.0 \\
\hline Hepatic Enzymes Increased & 1.3 & 0.0 & & - \\
\hline \multicolumn{5}{|l|}{ Metabolic and Nutritional } \\
\hline Alkaline Phosphate Increased & 2.5 & 1.4 & 1.0 & 0.0 \\
\hline Weight Decrease & - & - & 2.4 & 0.8 \\
\hline Hypoglycemia & 13 & 0.0 & - & - \\
\hline \multicolumn{5}{|l|}{ Musculoskeletal System } \\
\hline Arthraigia & - & - & 6.7 & 5.0 \\
\hline Arthritis & - & - & 2.9 & 0.8 \\
\hline Arthritis Aggravated & 1.3 & 0.0 & 1.4 & 0.0 \\
\hline \multicolumn{5}{|c|}{ Myocardial, Endocardial, Pericardlal Valve } \\
\hline Myocardial Ischemia & 1.3 & 0.7 & - & - \\
\hline \multicolumn{5}{|l|}{ Psychiatric } \\
\hline Somnolence & 40.1 & 6.1 & 20.2 & 8.3 \\
\hline Anxiety & - & - & 6.3 & 3.3 \\
\hline Confusion & 5.1 & 1.4 & 8.7 & 1.7 \\
\hline Hallucination & 5.1 & 1.4 & 10.1 & 4.2 \\
\hline Nervousness & - & - & 4.8 & 2.5 \\
\hline Yawning & 3.2 & 0.0 & - & - \\
\hline Amnesia & 2.5 & 1.4 & 4.8 & 0.8 \\
\hline Dreaming Abnormal & - & - & 2.9 & 1.7 \\
\hline Depersonalization & - & - & 1.4 & 0.0 \\
\hline Paranoid Reaction & - & - & 1.4 & 0.0 \\
\hline Agitation & 1.3 & 0.7 & 1.0 & 0.0 \\
\hline Concentration Impaired & 1.9 & 0.0 & 1.0 & 0.0 \\
\hline Illusion & 1.3 & 0.0 & - & - \\
\hline Thinking Abnormal & - & - & 1.4 & 0.8 \\
\hline Apathy & - & - & 1.0 & 0.0 \\
\hline Increased Libido & - & - & 1.0 & 0.0 \\
\hline Personality Disorder & - & - & 1.0 & 0.0 \\
\hline \multicolumn{5}{|l|}{ Red Blood Cell } \\
\hline Anemia & - & - & 2.4 & 0.0 \\
\hline Reproductive Male & & & & \\
\hline $\begin{array}{l}\text { Impotence } \\
\text { Prostatic Disorder }\end{array}$ & 2.5 & $\begin{array}{l}1.4 \\
-\end{array}$ & $\overline{10}$ & $\overline{0.0}$ \\
\hline Penis Disorder & - & - & 1.3 & 0.0 \\
\hline Resistance Mechanism & & & & \\
\hline Upper Respiratory Tract Intection & on - & - & 8.7 & 8.3 \\
\hline Intection Viral & 10.8 & 3.4 & 7.2 & 6.7 \\
\hline Respiratory System & & & & \\
\hline Pharyngitis & 6.4 & 4.1 & - & - \\
\hline Rhinitis & 3.8 & 2.7 & - & - \\
\hline Sinusitis & 3.8 & 2.7 & - & - \\
\hline Dyspnea & 3.2 & 0.0 & 2.9 & 1.7 \\
\hline Bronchitis & 2.5 & 1.4 & - & \\
\hline Respiratory Disorder & 1.9 & 1.4 & 1.9 & 0.0 \\
\hline Pneumonia & 1.3 & 0.7 & 1.0 & 0.8 \\
\hline Coughing & - & $=$ & 1.4 & 0.8 \\
\hline $\begin{array}{l}\text { Skin/Appendages } \\
\text { Pruritis }\end{array}$ & - & - & 1.0 & $0.0^{\circ}$ \\
\hline Urinary System & & & & \\
\hline Urinary Tract Intection & 5.1 & 4.1 & 6.3 & 2.5 \\
\hline Cystitis & 1.3 & 0.7 & - & - \\
\hline Micturition Frequency & - & - & 1.4 & 0.0 \\
\hline Pyuria & - & - & 1.9 & 0.8 \\
\hline Urinary Incontinence & - & - & 1.9 & 0.8 \\
\hline Urinary Retention & 1.3 & 0.7 & - & - \\
\hline Dysuria & - & - & 1.0 & 0.0 \\
\hline Vascular Extracardiac & & & & \\
\hline Peripheral Ischemia & 2.5 & 0.0 & - & - \\
\hline Vision & & & & \\
\hline Vision Abnorma: & 5.7 & 3.4 & - & - \\
\hline Eye Abnormality & 3.2 & 1.4 & - & - \\
\hline Diplopia & - & - & 1.9 & 0.8 \\
\hline Xerophthalmia & 1.9 & 0.0 & 1.4 & 0.8 \\
\hline Cataract & - & - & 1.4 & 0.8 \\
\hline Lacrimation Abnormal & - & - & 1.4 & 0.0 \\
\hline White Cell and Reticuloendot & othelial c & & & \\
\hline Eosinophilia & & - & 1.4 & 0.0 \\
\hline
\end{tabular}

a: Incidence of adverse event $<1 \%$

Post-Marketing Experience - Patients treated with REQUIPs have rarely reported suddenly falling asleep while engaged in activities of daily living, including operation of motor vehicles which has sometimes resulted in accidents (see WARNINGS).

DOSAGE AND ADMINISTRATION: REQUIP® (ropinirole hydrochloride) should be taken three times daily. While administration of REQuUP ${ }^{8}$ with meals may improve gastrointestinal tolerance, REQUIP ${ }^{\text {es }}$ may be taken with or without food. The recommended starting dosage is $0.25 \mathrm{mg}$ three times daily. Based on individual patient response, dosage should then be titrated by weekly increments of $0.25 \mathrm{mg}$ per dose as described in the table below. After week 4. daily dosage may be increased by 0.5 to $1.0 \mathrm{mg}$ per dose on a weekly basis until an optimal therapeutic response is established. Smaller dose increments are recommended for patients who may be at risk for orthostatic symptoms.

\begin{tabular}{|lcccc|}
\hline & \multicolumn{5}{c|}{ Week } \\
\hline & 1 & 2 & 3 & 4 \\
\hline Unit Dose (mg) & 0.25 & 0.5 & 0.75 & 1.0 \\
\hline Total Daily Dose (mg) & 0.75 & 1.5 & 2.25 & 3.0 \\
\hline
\end{tabular}

In clinical trials, initial benefits were observed with $3 \mathrm{mg} /$ day and higher doses. Doses greater than $24 \mathrm{mg} /$ day have not been included in clinical trials. In a 5 year, double-bilind study of early therapy in Parkinson's disease patients, the average daily oose of REQUIPक (based on the observed data set) was $10.1 \mathrm{mg}$ at 6 months (median dose $=9.0 \mathrm{mg}$ ), $14.4 \mathrm{mg}$ at 3 years (median dose $=15.0$ $\mathrm{mg}$ ), and $16.6 \mathrm{mg}$ at 5 years (median dose $=18.0 \mathrm{mg}$ ), regard less of levodopa supplementation. When REQUIPO is administered as adjunct therapy to levodopa, the dose of levodopa may be decreased gradually as tolerated once a therapeutic effect with REQUIPo has been observed. REQUIP should be discontinued gradually over a 7 -day period. The frequency of administration should be reduced from three times daily to twice daily for 4 days. For the remaining 3 days, the frequency should be reduced to once daily prior to complete withdrawal of REQUIP . Renal and Hepatic Impairment: In patients with mild to moderate renal impairment, REQUIP may be titrated in the recommended manner according to clinical response. Patients with severe renal impairment or on hemodialysis have not been studied and administration of REQUIP to such patients is not recommended. Patients with hepatic impairment have not been studied and administration of REQUIPa to such patients is not recommended. Estrogen Replacement Therapy: in patients already receiving estrogen replacement therapy, REQUPP may be titrated in the recommended manner according to clinical response. However, if estrogen replacement therapy is stopped or started during treatment with REQUIP ${ }^{\circledR}$, adjustment of the REQUIP ${ }^{\infty}$ dosage may be required AVAILABILITY OF DOSAGE FORM: REQUIP is supplied as a pentagonal film-coated Tiltab $^{\text {क }}$ tablet with beveled edges containing ropinirole (as ropinirole hydrochloride) as follows: $0.25 \mathrm{mg}$ - white imprinted with SB and 4890; $1.0 \mathrm{mg}$ - green imprinted with SB and 4892; $2.0 \mathrm{mg}$ - pale pink imprinted with $\mathrm{SB}$ and $4893 ; 5.0 \mathrm{mg}$ - blue tablets imprinted with $\mathrm{SB}$ and 4894. REQUIP ${ }^{\Phi}$ is available in bottles in the pack size of 100 tablets. Full Product Monograph available to practitioners upon request.

GlaxoSmithkline inc

7333 Mississauga Road North

Mississauga, Ontario

$\lfloor 5 N 6 L 4$

REQUIP ${ }^{\otimes}$ is a registered trademark, used under license by GlaxoSmithKline Inc. Date of preparation: June 18, 2001

Date of revisions: July 31, 2002

1. Rascol 0 et al. A five-year study of the incidence of dyskinesia in patients with early Parkinson's disease who were treated with ropinirole or levodopa. N Eng J Med 2000;342(20):1484-1491. 2. Product Monograph of ReQuip (ropinirole hydrochloride), GlaxoSmithKline, July 31, 2002.

\section{gSk GlaxoSmithKline $\stackrel{\text { Member }}{\mathrm{R} \& \mathrm{D})} \stackrel{\mathrm{PAB}^{*}}{ }$}

Hepatic Impairment

The pharmacokinetics of almotrictari heve rot been assessed in this propulation. The

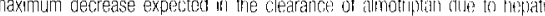

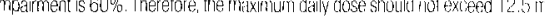
over a 24 hour period, and a stating dose of $6.25 \mathrm{mg}$ stoud he tsed see ACron AND CLINCAL PHARMACOLOGY, Special POPAlations and PHECAUIII(UNS) Renal Impairment

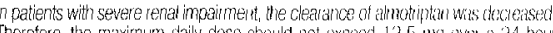
Theretore, the maximum daly dose should not exceed 12.5 nig ovet a 24 ho

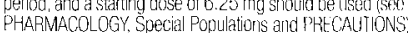

\section{PHARMACEUTICAL INFORMATION}

Drug Substance

Proper Name

Chemical Narre:

almotriptan malate

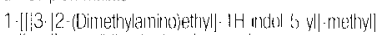

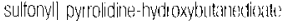

Structural Formula:

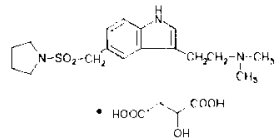

Molecular Formula

C. H. N.O.S.C.H.

46956

Molecular Weignt:

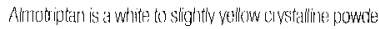

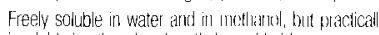
insolutitle in ethandel and methylent: cteterite

Solubility.

pka

Melting Point

8.77 at $22 \pm 2 " \mathrm{C}$

$167 \quad 1730$

$\mathrm{pH}:$

Partition Coefificient:

1\% solution in purifiad water has pht 4.

A partition coefficient of 0.008 between cetanlol anic

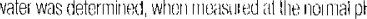
value (5.4-6.3) tor pusified wites

Composition

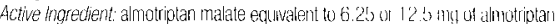

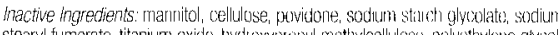

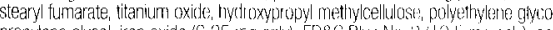

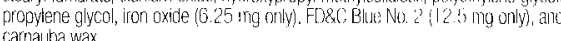

\section{Stability and Storage Recommendations}

AKERT tablets should be stored between $15 \cdot 30^{\circ} \mathrm{C}$

\section{AVAILABILITY OF DOSAGE FOAMS}

AXERT (almotriptarn malate) tablets are available throunh prescription (inly.

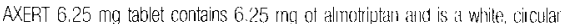

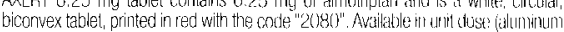
bi ister packi) of 6 tablets

AXERT $12.5 \mathrm{mg}$ tablet contains $12.5 \mathrm{mg}$ of almotiptiant and is is a white, circulal

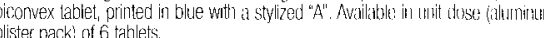

AXERT is a Sctiedule F drug

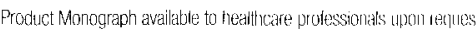

\section{JANSSEN-ORTHO}

JANSSEN-ORTHO IIC

Toronto, Ontario M3C $1 \mathrm{Lg}$

Date of Issuance: October 2003

Licensed from: EAlmirall

AXP1041006A

(C) 2003 JANSSEN-ORTHO InC

*All trademark rights used under license 


\section{AVONEX (Interferon beta-la)}

\section{PRESCRIBING INFORMATION}

\section{THERAPEUTIC CLASSIFICATION}

Immunomodulator

\section{INDICATIONS AND CLINICAL USE}

AVONEX (Interferon beta-1a) is indicated for the treatment of relapsing torms of multiple sclefosis to slow the progression of disability decrease the frequency of clinical exacerbations, and reduce the number and volume of active brain lesions identitied on Magnetic Resonance Imaging (MRI) scans. Satety and efficacy have not been eval uated in patients

with chronic progressive multiple sclerosis

\section{CONTRAINDICATIONS}

AVONEX (Interferon beta-1a) is contraindicated in patients with a history o hypersensitivity to natural of recombinant interferon beta, human albumin, or any other component of the formulation.

\section{WARNINGS}

AVONEX (Interferon beta-1a) should be used with caution in patients with depression. Depression and suicide have been reported to occur in patients receiving other interferon compounds. Depression and suicidal ideation are known to occur at an increased frequency in the MS population. A relationship between the occurrence of depression and/or suicidal ideation and the use of AVONEX" has not been established. An equal incidence of depression was

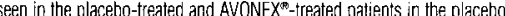
controlled relapsing MS study. Patients treated with AVONEX should be advised to report immediately any symptoms of depression and/or suicida ideation to their prescribing physicians. If a patient develops depression antidepressant theracy or cessation of AVONEX therapy should be considered.

\section{PRECAUTIONS}

General

Caution should be exercised when administering AVONEX (Interferon beta-1a) to patients with pre-existing seizure disorder. In the placebo-controlled study, 4 patients receiving AVONEX experienced seizures, while no seizures occurre in the placebo grcup Of these 4 patients, 3 had no prior history of seizure. If is not known whether these events were related to the effects of MS alone, to AVONEX, or to a combination of both. For patients with no prior history of seizure who developed seizures during therapy with $A V O N E X^{(B 8}$, an etiologic basis should be estabilished and appropriate anti-convuisant therapy instituted prior to considering resumption of AVONEX treatment. The effect of AVONEX administration on the medical management of patients with seizure disorder is unknown.

Patients with cardiac disease, such as angina, congestive heart failure, or arrhythmia, should be closely monitored for worsening of their clinica condition during initiation of therapy with AVONEX AVONEX does not have any known direct-acting cardiac toxicity; however, symptoms of flu syndrome seen with AVONEX therapy may arove stressful to patients with severe cardiac conditions.

\section{Laboratory Tests}

In addition to those laboratory tests normally required for monitoring patients with MS, complete blood cell counts and white blood cell differential platelet counts, and blood chemistries, including liver and thyrcio function tests, are recommended during AVONEX therapy. During the placebo-controlled study, complete blood cell counts and white blood cell difterential, platelet counts, and blood chemistries were performed at least every 6 months. There were no significant differences between the placebo and AVONEX groups in the incidence of thyroid abnormalities, liver enzyme elevation, leukooenia, or thrombocytopenia (these are known to be dose-related laboratory abnormalities associated with the use of interferons). Patients with myelosuppression may require more intensive monitoring of complete blood cell counts, with differential and platelet counts.

\section{Drug Interactions}

No formal drug interaction studies have been conducted with AVONEX In the placebo-controlled study, corticosteroids or ACTH were administered for treatment of exacerbations in some patients concurrently receiving AVONEX . In addition, some patients receiving AVONEX were also treated with anti-depressant therapy and/or oral contraceptive therapy. No unexpected adverse events were associated with these concomitant therapies.

Other interferons have been noted to reduce cytochrome $P$ - 450 oxidase-mediated drug metabolism. Formai hepatic drug metabolism studies with AVONEX in humans have not been conducted. Hepatic microsomes isolated from AVONEX-treated rhesus monkeys showed no influence of AVONEX' on hepatic P-450 enzyme metabolism activity. As with all interferon products, proper monitoring of patients is required if AVONEX is given in combination with myelosuppressive agents

\section{Use in Pregnancy}

If a wornan becomes pregnant or plans to become pregnant while taking AVONEX", she should be informed of the potential hazards to the fetus, and should be recommended that the woman discontinue therapy. The reproductive toxicity of AVONEX" has not been studied in animals or humans. In pregnant monkeys given interferon beta al 100 times the recommended weekly human dose (based upon a body surface area comparison), no teratogenic or other adverse effects on fetal development were observed. Abortifacient activity was evident following 3 to 5 doses at this level. No abortifacient effects were observed in monkeys treated at 2 times the recommended weekly human dose (based upon a body surface area comparison).
Although no teratogenic effects were seen in these studies, it is not known if teratogenic effects would be observed in humans. There are no adequate and well-controlled studies with interferons in pregnant women.

\section{Nursing Mothers}

It is not known whether AVONEX is excreted in human milk. Because of the potential of serious adverse reactions in nursing infants, a decision should be made to either discontinue nursing or to discontinue AVONEX ${ }^{*}$

\section{Pediatric Use}

Safety and effectiveness have not been established in pediatric patients below the age of 18 years.

\section{Intormation to Patients}

Patients should be informed of the most common adverse events associated with AVONEX administration, including symptoms associated with flu syndrome (see Adverse Events and Intormation for the Patient) Symptoms of fiu syndrome are most prominent at the initiation of therapy and decrease in frequency with continued treatment. In the placebo-controlled study patients were instructed to take $650 \mathrm{mg}$ acelaminophen immediately prior to injection and for an additional 24 hours after each injection to modulate acute symptoms associated with AVONEX administration. Patients should be cautioned to report depression or suicidal ideation (see Warnings)

When a physician determines that AVONEX can be used outside of the physician's office, persons who will be administering AVONEX should receive instruction in reconstitution and injection, including the review of the injection procedures (see Information for the Patient). If a patient is to self-administer, the physical ability of that patient to self-inject intramuscularly should be assessed. If home use is chosen, the first injection should be performed under the supervision of a qualified health care professional. A puncture-resistant container for disposal of needles and syringes should be used. Patients should be instructed in the technique and importance of proper syringe and needle disposal and be cautioned against reuse of these iterns.

\section{ADVERSE EVENTS}

The satety data describing the use of AVONEX (Interferon beta-1a) in MS patients are based on the placebo-controlled trial in which 158 patients randomized to AVONEX ${ }^{\odot}$ were treated for up to 2 years.

The 5 most common adverse events associated (at $p<0.075$ ) with AVONEX treatment were flu-like symptoms (otherwise unspecified), muscle ache fever, chills, and asthenia. The incidence of all 5 adverse events diminished with continued treatment.

One patient in the placebo group attempted suicide; no AVONEXs-treated patients atternpted suicide. The incidence of depression was equal in the 2 treatment groups. However, since depression and suicide have been reported with other interferon products, AVONEX should be used with caution in patients with depression (see Warnings).

In the placebo-controlled study, 4 patients receiving AVONEX experienced seizures, while no seizures occurred in the placebo group. Of these 4 patients, 3 had no prior history of seizure. It is not known whether these events were related to the effects of MS atone to AVONEX or to a combination of both (see Precautions).

Table 1 enumerates adverse events and selected laboxatory abnormalities that occurred at an incidence of $2 \%$ or more among the 158 patients with relapsing MS treated with $30 \mathrm{mcg}$ of AVDNEX ${ }^{\mathbb{E}}$ once weekly by IM injection. Reported adverse events have been classified using standard COSTART terms. Terms so general as to be uninformative or more common in the placebo-treated patients have been excluded.

AVONEX has a so been eval uated in 290 patients with illnesses other than MS. The majority of these patients were enrolled in studies to evaluate AVONEX treatment of chronic viral hepatitis $B$ and $C$, in which the doses studied ranged from $15 \mathrm{mcg}$ to $75 \mathrm{mcg}$, given subcutaneously ( $\mathrm{SC}$ ). 3 times a week, for up to 6 months. The incidence of common adverse events in these studies was generally seen at a frequency similar to that seen in the placebo-controlled MS study. In these non-MS studies, inflammation at the site of the SC injection was seen in $52 \%$ of treated patients in contrast injection site inflammation was seen in $3 \%$ of MS patients receiving AVONEX $X^{\oplus}, 30 \mathrm{mcg}$ by $\mathrm{IM}$ injection. SC injections were also associated with the following local reactions: injection site necrosis, injection site atrophy. injection site edema, and irjection site hermorrhage. None of the above was observed in the MS patients participating in the placebo-controlled study.

\begin{tabular}{|c|c|c|}
\hline Adverse Event & $\begin{array}{c}\text { Placebo } \\
(\mathrm{N}=143)\end{array}$ & $\begin{array}{c}\text { AVONEX } \\
(\mathrm{N}=158)\end{array}$ \\
\hline \multicolumn{3}{|l|}{ Body as a Whole } \\
\hline Headache & $57 \%$ & $67 \%$ \\
\hline Flu-like symptoms (otherwise unspecified) ${ }^{*}$ & $40 \%$ & $\begin{array}{l}61 \% \\
24 \%\end{array}$ \\
\hline $\begin{array}{l}\text { Pain } \\
\text { Fever }^{*}\end{array}$ & $\begin{array}{l}20 \% \\
13 \%\end{array}$ & $\begin{array}{l}24 \% \\
23 \%\end{array}$ \\
\hline Asthenia & $13 \%$ & $21 \%$ \\
\hline Chills ${ }^{*}$ & $7 \%$ & $21 \%$ \\
\hline Infection & $6 \%$ & $11 \%$ \\
\hline Abdominal pain & $6 \%$ & $9 \%$ \\
\hline Chest pain & $4 \%$ & $6 \%$ \\
\hline In ection site reaction & $1 \%$ & $4 \%$ \\
\hline Malaise & $3 \%$ & $4 \%$ \\
\hline Injection site inflammation & $0 \%$ & $3 \%$ \\
\hline Hypersensitivity reaction & $0 \%$ & $3 \%$ \\
\hline Ovarian cyst & $0 \%$ & $3 \%$ \\
\hline Ecchymosis injection site & $1 \%$ & $2 \%$ \\
\hline \multicolumn{3}{|l|}{ Cordiovascular System } \\
\hline Syncope & $2 \%$ & $4 \%$ \\
\hline Vasodilation & $1 \%$ & $4 \%$ \\
\hline
\end{tabular}

Table 1 Adverse Events and Selected Laboratory Abnormalities in the Placebo-Controlled Study

\begin{tabular}{|c|c|c|}
\hline Adverse Event & $\begin{array}{c}\text { Plocebo } \\
(N=143)\end{array}$ & $\begin{array}{l}\text { AVONEX } \\
(\mathrm{N}=158)\end{array}$ \\
\hline \multicolumn{3}{|l|}{ Digestive System } \\
\hline Nausea & $23 \%$ & $33 \%$ \\
\hline Diarhea & $10 \%$ & $16 \%$ \\
\hline Dyspepsia & $7 \%$ & $11 \%$ \\
\hline Anorexia & $6 \%$ & $7 \%$ \\
\hline \multicolumn{3}{|l|}{ Hemic and Lymphatic System } \\
\hline Anemia $^{*}-100$ & $3 \%$ & $8 \%$ \\
\hline $\begin{array}{l}\text { Eosinophils } \geq 10 \% \\
\text { HCT }(\%) \leq 32 \text { (temales) }\end{array}$ & $4 \%$ & $5 \%$ \\
\hline or $\leq 37$ (males) & $1 \%$ & $3 \%$ \\
\hline \multicolumn{3}{|l|}{ Metabolic and Nutritional Disorders } \\
\hline $\mathrm{SGOT} \geq 3 \times$ ULN & $1 \%$ & $3 \%$ \\
\hline \multicolumn{3}{|l|}{ Musculoskeletal System } \\
\hline Muscle ache* ${ }^{*}$ & $15 \%$ & $34 \%$ \\
\hline Arthralgia & $5 \%$ & $9 \%$ \\
\hline \multicolumn{3}{|l|}{ Nervous System } \\
\hline Sleep difficult & $16 \%$ & $19 \%$ \\
\hline Dizziness & $13 \%$ & $15 \%$ \\
\hline Muscle spasm & $6 \%$ & $7 \%$ \\
\hline Suicidal tendency & $1 \%$ & $4 \%$ \\
\hline Seizure & $0 \%$ & $3 \%$ \\
\hline Speech disorder & $0 \%$ & $3 \%$ \\
\hline Ataxia & $0 \%$ & $2 \%$ \\
\hline \multicolumn{3}{|l|}{ Respiratory System } \\
\hline Upper respiratory tract infection & $28 \%$ & $31 \%$ \\
\hline Sinusitis & $17 \%$ & $18 \%$ \\
\hline Oyspnea & $3 \%$ & $6 \%$ \\
\hline \multicolumn{3}{|l|}{ Skin and Appendages } \\
\hline Urticaria & $2 \%$ & $5 \%$ \\
\hline Alopecia & $1 \%$ & $4 \%$ \\
\hline Nevus & $0 \%$ & $3 \%$ \\
\hline Herpes zoster & $2 \%$ & $3 \%$ \\
\hline Herpes simplex & $1 \%$ & $2 \%$ \\
\hline \multicolumn{3}{|l|}{ Special Senses } \\
\hline Otitis media & $5 \%$ & $6 \%$ \\
\hline Hearing decreased & $0 \%$ & $3 \%$ \\
\hline \multicolumn{3}{|l|}{ Urogenital } \\
\hline Vaginitis & $2 \%$ & $4 \%$ \\
\hline
\end{tabular}

(N=143) $\quad(N=158)$

Significantly associated with AVONEX ${ }^{\circ}$ treatment $(p \leq 0.05)$

\section{DOSAGE AND ADMINISTRATION}

The recommended dosage of AVONEX $X^{B}$ (Interferon beta-1a) for the treatment of relapsing forms of multiple sclerosis is $30 \mathrm{mcg}$ injected intramuscularly once a week

AVONEX ${ }^{B}$ is intended for use under the guidance and supervision of a physician. Patients may self-inject only if their physician determines tha: it is appropriate and with medical follow-up, as necessary, after proper training in IM injection technique.

\section{AVAILABILITY OF DOSAGE FORMS}

AVONEX (Interferon beta-1a) is available as:

Package (Administration Pack) containing 4 Administration Dose Packs (each containing one vial of AVONEX one $10 \mathrm{~mL}(10 \mathrm{cc})$ diluent vial two alcchol wipes, one gauze pad, one $3 \mathrm{cc}$ syringe, one Micro Pin ${ }^{p}$. one needle, and one adhesive bandage).

Product Monograph Available upon request

\section{REFERENCES}

Galetta SL, Markowitz C. Lee AG. Immunomoduiatory agents for the treatment of relapsing multiple sclerosis. Arch intern Med 2002 162:2161-2169.

2. Bertolotto A, Malucchi S, Sala A, et al. Differential effects of three interferon betas on neutralizing antibodies in patients with multiple sclerosis: a follow-up study in an independent laboratory. $J$ Neurol Neurosurg Psychiatry 2002:73:148-153.

3. Giovannoni $G$. Munschauer FE Deisenhammer F. Neutralizing antibodies to interferon beta during the treatment of multiple sclerosis. J Neuro Neurosurg PSychiatry 2002;73;465-469.

4. Rudick RA, Simonian NA, Alam JA, Incidence and significance of neutraiizing antibodies to interferon beta-1a in multiple sclerosis. Neurology 1998:50:1266-1272.

5. AVONEX product monograph, 2000.

6. Rudick RA, Fisher E, Lee JC, et al. Use of the brain parenchymal fraction to measure whole brain atrophy in relapsing-remitting MS. Neurology 1999;53:1698-1704.

7. Data on file, Biogen, Inc

\section{1-888-456-2263 BIQEN}

CA NADA

3 Robert Speck Parkway, Suite 300, Mississauga, Ontario L4Z 2G5 (c) 2003 Biogen Canada, Inc. All rights reserved

Biogen Canada is a trademark of Biogen, Inc.

AVONEX is a registered trademark of Biogen, Inc.

Rebif is a registered trademark of Serono Canada Inc

Betaseron is a registered trademark of Berlex Canada lnc.
Micro Pin ${ }^{\star}$ is a registered trademark of $\mathrm{B}$. Braun Medical lnc. 
seringue et un adaptateur de flacon stériles afin de prélever $1,1 \mathrm{~mL}$ du diluant fourni (eau stérile pour injection) et de linjecter dans le flacon de COPAXONE. Agiter tres delicatement, par un mouvement de rotation, le lacon de COPAXONE et le laisser reposer à la température ambiante jusqu'à dissolution complète du lyophilisat. Inspecter visuellement le produit reconstitue et le jeter ou le retourner au pharmacien avant de la solution à l'aide d'une seringue stérile. Retirer l'adaptateur de flacon, connecter une aiguille de calibre 27 et injecter la solution par voie sous-cutanée. Les points d'auto-administration comprennent les bras, l'abdomen, les fesses et les cuisses. Un flacon ne convient qu'à une seule utilisation; toute portion inutilisée doit être jetée (voir INFORMATION A L'INTENTION DU PATIENT, Produit reconstitué)

Pour obtenir les directives concernant la préparation et l'injection de COPAXONE" au moyen de la seringue préremplie, voir INFORMATION A L'INTENTION DU PATIENT, Seringue préremplie.

\section{RENSEICNEMENTS PHARMACEUTIQUES}

Substance médicamenteuse

Nom propre:

Chimique:

Acétate de glatiramère

Description :

L'acétate de glatiramère est le sel acétate de polypeptides synthétiques.

tacetate de glatiramere est prepare par reaction chimique des dérives activés de quatre acides aminés: I'acide L-glutamique (L-Glu), la L-alanine (L-Ala), la L-tyrosine (L-Tyr) et la L-tysine (L-tys) dans une proportion specitique ta traction molaire de chave residu dacide amine sechelonne comme suit:

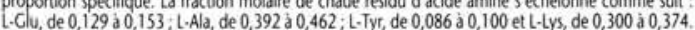

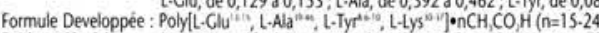

Poids moléculaire : Le poids moléculaire moyen du polypeptide se situe entre 4700 et 11000 daltons, au moins $68 \%$ du matériel se situant entre 2500 et 22500 daltons.

Description Physique : Lyophilisat de couleur blanche à légerement jaunătre.

$\begin{array}{ll}\text { Solubilité : } & \text { Légèrement soluble dans l'eau, insoluble dans l'acétone. } \\ & \text { Le } \mathrm{pH} \text { d'une solution à } 0,5 \% \mathrm{p} / \mathrm{V} \text { d'acétate de glatiramère dans de l'eau se situe entre } 5,5 \text { et } 8,0 \text {. }\end{array}$

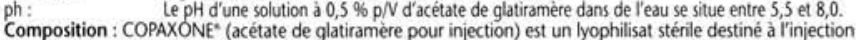
sous-cutanée après reconstitution avec de l'eau stérile pour injection. Un flacon de lyophilisat renferme $20 \mathrm{mg}$ d'acétate de glatiramère et un surtitrage de $2 \mathrm{mg}$ pour tenir compte des pertes possibles pendant la reconstitution et le prélèvement ainsi que $40 \mathrm{mg}$ de mannitol. Un flacon d'eau stérile pour injection renferme $1,1 \mathrm{~mL}$ d'eau stérile pour injection et un surtitrage de $0,35 \mathrm{~mL}$ pour tenir compte des pertes possibles pendant a reconstitution et le prélèvemen

COPAXONE' (acétate de glatiramère injectable) est présenté en seringue préremplie à usage unique renfermant $20 \mathrm{mg} / 1,0 \mathrm{~mL}$ de solution stérile équivalant à la solution reconstituée de COPAXONE (c.à-d., $20 \mathrm{mg} / \mathrm{mL}$ d'acétate de glatiramère et $40 \mathrm{mg}$ de mannitol dans de l'eau stérile pour injection.

Stabilité et conditions d'entreposage : Les flacons de lyophilisat de COPAXONE' doivent être réfrigérés (entre 2 et $8^{\circ} \mathrm{C}$ ). COPAXONE* peut également être conservé a la température ambiante (entre 15 et $30^{\circ} \mathrm{C}$ ) pendant un maximum de 14 jours. Les flacons de diluant (eau stérile pour injection) doivent étre conservés à la température ambiante,

Les seringues préremplies de COPAXONE*' doivent ètre réfrigérées dès leur réception (entre 2 et $8^{\circ} \mathrm{C}$ ). NE PAS CONCELER.

$S^{\prime}$ in n'est pas possible de conserver les seringues préremplies de COPAXONE" au réfrigérateur, elles peuvent ètre conservées à la température ambiante (entre 15 et $30^{\circ} \mathrm{C}$ ) pendant un maximum d'une semaine. Ne pas conserver les seringues préremplies de COPAXONE" à la température ambiante pendant plus de sept jours. Remarque : ce médicament est sensible à la lumière, le protéger de la lumière lorsqu'on ne tait pas d'injection. Une seringue préremplie ne doit servir qu'une seule fois,

Reconstitution du lyophilisat : Pour reconstituer le lyophilisat de COPAXONEs, avant l'injection, utiliser une seringue et un adaptateur de flacon stériles a fin de prélever le diluant fourni (eau stérile pour injection) et de l'injecter dans le flacon de COPAXONEs. Agiter très délicatement, par un mouvement de rotation, le flacon de COPAXONE*" et le laisser reposer à la temperature ambiante jusqu'à dissolution complète du lyophilisat. Inspecter visuellement le produit reconstitué et le jeter ou le retourner au pharmacien avant l'utilisation s'il renferme des particules. Une fois le produit complètement dissous, prélever $1,0 \mathrm{~mL}$ de la solution à l'aide d'une seringue stérile. Retirer l'adaptateur de flacon, connecter une aiguille de calibre 27 et injecter la solution par voie sous-cutanée. Un flacon ne convient qu'à une seule utilisation ; toute portion inutilisée doit être jetee. La solution reconstituee ne doit pas etre conservee plus de huit heures al a température ambiante. Produits parentéraux : COPAXONE" ne doit être reconstitué qu'avec le diluant fourni (eau sterile pour injection).

\begin{tabular}{|c|c|c|c|}
\hline $\begin{array}{c}\text { Format du } \\
\text { flacon }\end{array}$ & $\begin{array}{c}\text { Volume de diluant à } \\
\text { ajouter }\end{array}$ & $\begin{array}{c}\text { Volume à } \\
\text { injecter }\end{array}$ & $\begin{array}{c}\text { Concentration } \\
\text { nominale par } \mathrm{mL}\end{array}$ \\
\hline $2 \mathrm{~mL}$ & $1,1 \mathrm{~mL}$ & $1,0 \mathrm{~mL}$ & $20 \mathrm{mg}$ \\
\hline
\end{tabular}

\section{PRÉSENTATION}

COPAXONE' (acétate de glatiramêre pour injection) est offert sous la forme d'une dose de $20 \mathrm{mg}$ de yophilisat stérile d'acétate de glatiramere avec du mannitol, le produit étant conditionné dans des flacons yophisat sterile dacetate de glatiramere avec du mannitol, le produit etant conditionne dans des macons iniection) et un surtitrage de $0,35 \mathrm{~mL}$ accompagne chaque flacon de médicament et est inclus dans la trousse d'auto-administration. COPAX NE: (acétate de gatiràere pour iniection) est offert en emballages de 32 flacans de couleur. COPAXONE" (acetate de glatiramere pour injection) est offert en emballages de 32 flacons de couleur ambre renfermant le lyophilisat stérile destine a l injection sous-cutanee. Le diluant (eau sterile pour injection) accompagnant COPA COPAXONE" (acétate de glatiramère injectable) est présenté en seringues préremplies à usage unique renfermant $20 \mathrm{mg} / 1,0 \mathrm{~mL}$ de solution stenle equivalant a la solution reconstituee de COPAXONE. COPAXONE (acetate de glatiramère injectable) est offert en emballages de 30 seringues en verre préremplies a usage unique

Monographie fournie sur demande.

Bibliographie :

1. Monographie de COPAXONE* (acétate de glatiramère), Teva Neuroscience.
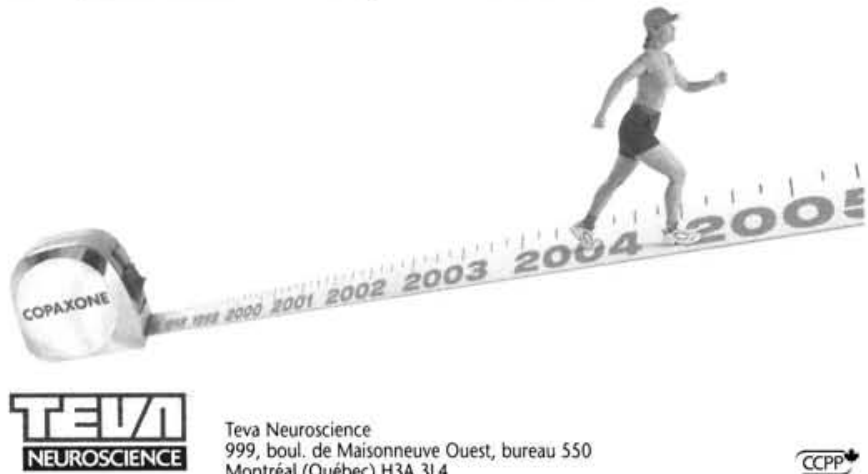

Teva Neuroscience

999, boul. de Maisonneuve Ouest, bureau 550

Montréal (Québec) H3A $3 L 4$

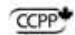

\section{Subscribe Now!}

\section{YES! Please send me a one-year subscription to the Journal, now including the ONLINE version at www.cjns.org}

Complete the enclosed subscription form and send by mail, fax or e-mail to:

Subscriptions

Canadian Journal of Neurological Sciences

PO Box 5456, Stn. A

Calgary AB Canada T2H 1 X8

Tel: (403) 229-9575

Fax: (403) 229-1661

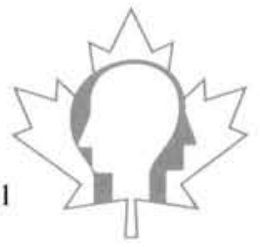

E-mail: journal@cjns.org

SUBSCRIPTION RATES (Print and Online) 2003

\begin{tabular}{llll} 
& Canada* $^{*}$ & US & $\begin{array}{l}\text { Other } \\
\text { Countries }\end{array}$ \\
\hline Non-Member Individual & $\$ C 80.00$ & \$US 80.00 & \$US 85.00 \\
Non-Member Student & $\$ C 40.00$ & \$US 40.00 & $\$$ \$U 42.50 \\
Institutions & $\$ C 90.00$ & \$US 90.00 & \$US 95.00
\end{tabular}

* add $7 \%$ GST or $15 \%$ HST

Agent discount $5 \%$

\begin{tabular}{ll}
\hline Subscription Rate & $\$$ \\
\hline$*$ Tax: GST 7\%/HST 15\% & $\$$ \\
\hline TOTAL & $\$$ \\
\hline
\end{tabular}

PAYMENT METHODS:

$\square$ Cheque
(\$C drawn on a Canadian bank and \$US drawn on a US bank)
$\square$ Visa $\square$ Mastercard

Credit Card No.:

Expiry date:

Signature:

Telephone:

Last Name:

First Name:

Address:

City:

Province/State:

Country:

Postal Code: 


\section{PEDIATRIC \\ Winnipeg Regional Health Authority \\ Office régional de la santé de Winnipeg}

UNIVERSITY

OF MANITOBA

The Department of Pediatrics and Child Health, Faculty of Medicine, University of Manitoba and the Child Health Program of the Winnipeg Regional Health Authority are seeking a contingent geographic full-time Pediatric Neurologist at the rank of Assistant Professor commencing August 1 st or as soon thereafter as possible. Position No: AEA 507. The successful applicant will join three other Pediatric Neurologists in the Section of Pediatric Neurosciences and in addition to basic clinical skills, should have an interest in either basic science research or clinical investigation. A special interest in Neuromuscular disorders and the ability to perform and interpret EMG and nerve conduction studies in children is preferred. The individual will also be expected to participate in the educational programs for undergraduate medical students, postgraduate pediatric residents and neurology fellows.

Winnipeg is a city of 650,000 providing care to a population of 1.1 million scattered over a wide geographic area. The cost of living is low and the quality of life is high. Arts and entertainment are excellent and accessible. Sports and recreation facilities are good. It is close to lakes and coltage country. The public education system is good. There is an excellent community spirit. Commuting is easy and quick.

The Winnipeg Children's Hospital Foundation has recently opened substantial research space and research start-up funds are available to qualified applicants.

Candidates must have Senior Specialty qualifications in Neurology in the country of current practice and must be eligible for registration with the College of Physicians and Surgeons of Manitoba. Certification in Neurology by the Royal College of Physicians and Surgeons of Canada is preferred.

Salary will be commensurate with experience and qualifications.

The University encourages applications from qualified women and men, including members of visible minorities, Aboriginal peoples and persons with disabilities. All qualified applicants are encouraged to apply; however, Canadians and permanent residents will be given priority. Application accompanied by a CV, a brief outline of specific interests and goals in both the short and long term, a list of publications and the names and addresses of three referees should be sent to:

Department Head

Department of Pediatrics \& Child Health

University of Manitoba

CE208-840 Sherbrook St.

Winnipeg, MB, R3A 1 S1

Fax: $204787-4807$

e-mail: pkarlenzig@exchange.hsc.mb.ca

Closing Date: applications will be accepted until position is filled however early application is advised.

In addition, general information can be found at the Health Sciences Centre Website at unw.hsc.mb.ca or the University of Manitoba Website at wuw.umanitoba.ca.

Application materials, including letters of reference, will be handled in accordance with the Freedom of information and Protection of Privacy Act (Manitoba).

\section{KING MEDICAL}

\section{THE CANADIAN ELECTRODE PLACE}

- AMBU Blue Sensor - Neuroline

- CHALGREN Bar/Ring/Clip Electrodes

- CLASS A Monopolar Needles

- KENDALL Adhesive - NuTab

- KING MEDICAL Cables \& Adapters

- MAVIDON Lemon \& Green Skin Prep

- MEDTRONIC Mono/Conc. Needles

- PARKER LAB. Electrode Paste

- 3M CANADA Micropore - Transpore

- D.O. WEAVER Ten20 • NuPrep

Bo-ject ${ }^{\mathrm{TM}}$ - Chalgren - Inoject $^{\mathrm{TM}}$ Large stock of Hypodermic Needles

Tel 905-833-3545

Fax 905-833-3543

E-mail: soren@kingmedical.com Web Site: www.kingmedical.com

King Medical Ltd.

145 Kingsworth Road

King City • Ontario L7B $1 \mathrm{~K} 1$

\section{ADVERTISERS INDEX}

Aventis

Altace - A-14, A-15

Bayer

Gamunex - A-18, A-19, A-42, A-43

Biogen

Avonex - A-10, A-13, A-52

GlaxoSmithKline

Imitrex - IBC, A-30, A-31

Requip - A-21, A-50, A-51

Janssen-Ortho

Axert - A-3, A-48, A-49, A-51

Reminyl - A-25, A-44, A-45, A-46, A-47

Topamax - A-6, A-7, A-36, A-37

Lundbeck

Keppra - A22, A-23, A-40, A-41

Pfizer

Aricept - OBC, A-27

Lipitor - A-9, A-38, A-39

Serono

Rebif - IFC, A-28, A-29

Teva Neuroscience

Copaxone-A-4, A-5, A-33, A-33, A-34, A-35, A-53

Classified Ads - A-54 


\section{OUR GOAL:}

- IMITREX ${ }^{\circledast}$ is effective at any stage of migraine pain ${ }^{\text {s. }}$

- IMITREX ${ }^{\circledast}$ at the first sign of pain reduced most attacks to $\mathrm{ZERO}^{24}$

- Nearly 1 out of 2 attacks reduced to ZERO PAIN $^{\mathrm{IM}}$ at 1 hour

- 2 out of 3 attacks reduced to ZERO PAIN ${ }^{\mathrm{TM}}$ at 2 hours

- 9 out of 10 attacks reduced to ZERO PAIN ${ }^{\mathrm{TM}}$ at 4 hours
$\%$ of Attacks Reduced to Zero Pain

(Based on a retrospective Analysis)"

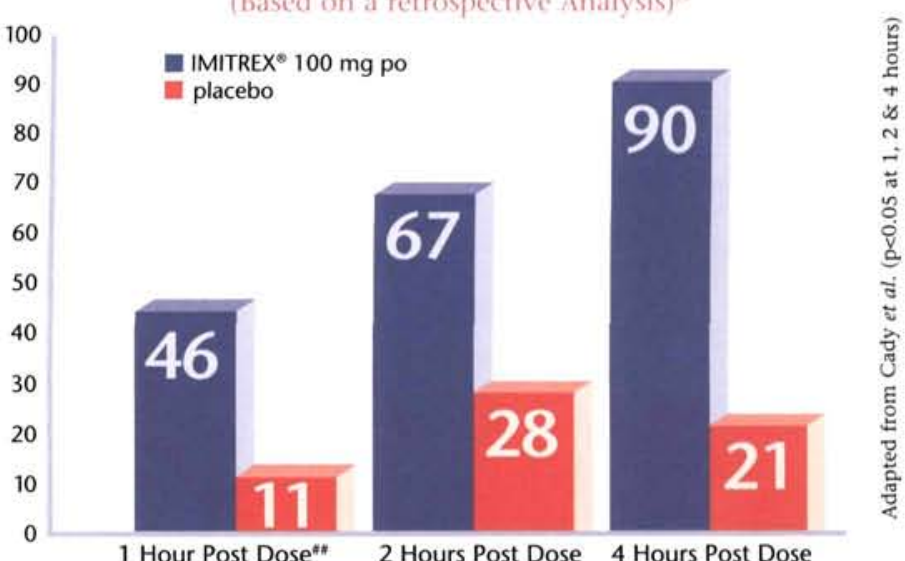

" 2 and 4 hour post dose time points were the primary endpoints.

\section{SUCCESS WITH JUST ONE DOSE}

$\%$ of attacks that did not require a second dose when treated early with IMITRE:

\section{-When IMITREX ${ }^{\circledast}$ was taken at first sign of pain ${ }^{\ddagger}, 80 \%$ of migraine attacks did not require a second dose ${ }^{2}$ \\ - Reduced need for a second dose $=$ Potential cost savings (acquisition cost only)}

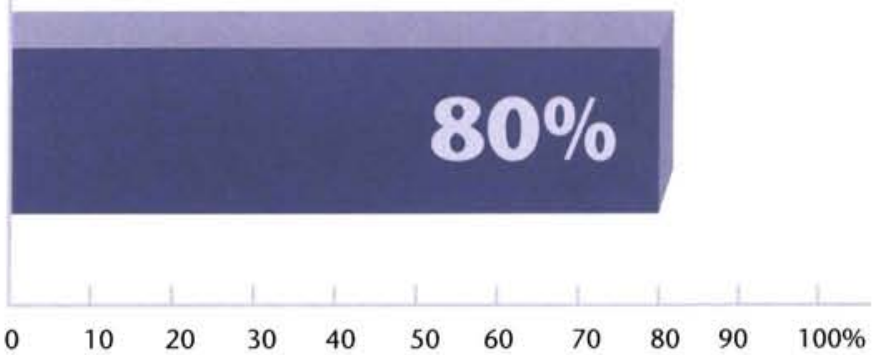

IMITREX $^{\star}$ (sumatriptan succinate/sumatriptan) is a selective 5- $\mathrm{HT}_{1}$ receptor agonist indicated for the acute treatment of migraine attacks with or without aura. ${ }^{1}$ IMITREX $^{\circledast}$ is not indicated for prophylactic therapy of migraine, or for the management of hemiplegic, basilar or ophthalmoplegic migraine. Safety and efficacy have not been established for cluster headache.'

IMITREX ${ }^{\star}$ is contraindicated in patients with history, symptoms, or signs of ischemic cardiac, cerebrovascular, or peripheral vascular syndromes, valvular heart disease or cardiac arrhythmias. In addition, patients with other significant underlying cardiovascular diseases should not receive IMITREX ${ }^{\star}$. IMITREX ${ }^{\star}$ is also contraindicated in patients with uncontrolled or severe hypertension.

The most common adverse events with IMITREX ${ }^{\circledR} 100 \mathrm{mg}$ tablets included: nausea ( $11.0 \% \mathrm{vs.} 5.8 \%$ placebo), malaise/fatigue $(9.5 \%$ vs. $5.1 \%$ placebo), sensations (body regions unspecified) (9.0\% vs. $4.5 \%$ placebo).

$\uparrow$ Refers to 0 (zero) on a 4 point pain scale where $0=$ no pain, $1=$ mild pain, $2=$ moderate pain and $3=$ severe pain.

$\triangle$ IMITREX* should not be used prophylactically. Administration during migraine aura prior to other symptoms occurring may not prevent the development of a headache.'

$¥$ Early intervention = treatment initiated at first sign of pain - when pain was mild, before progression to moderate-severe pain.

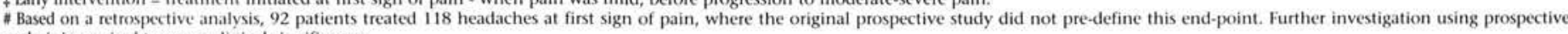
analysis is required to prove clinical significance.

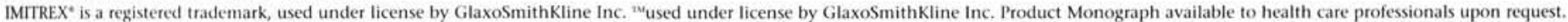


There's nothing better

than knowing he can still teach his granddaughter

an old favourite.<smiles>[TeH]</smiles>

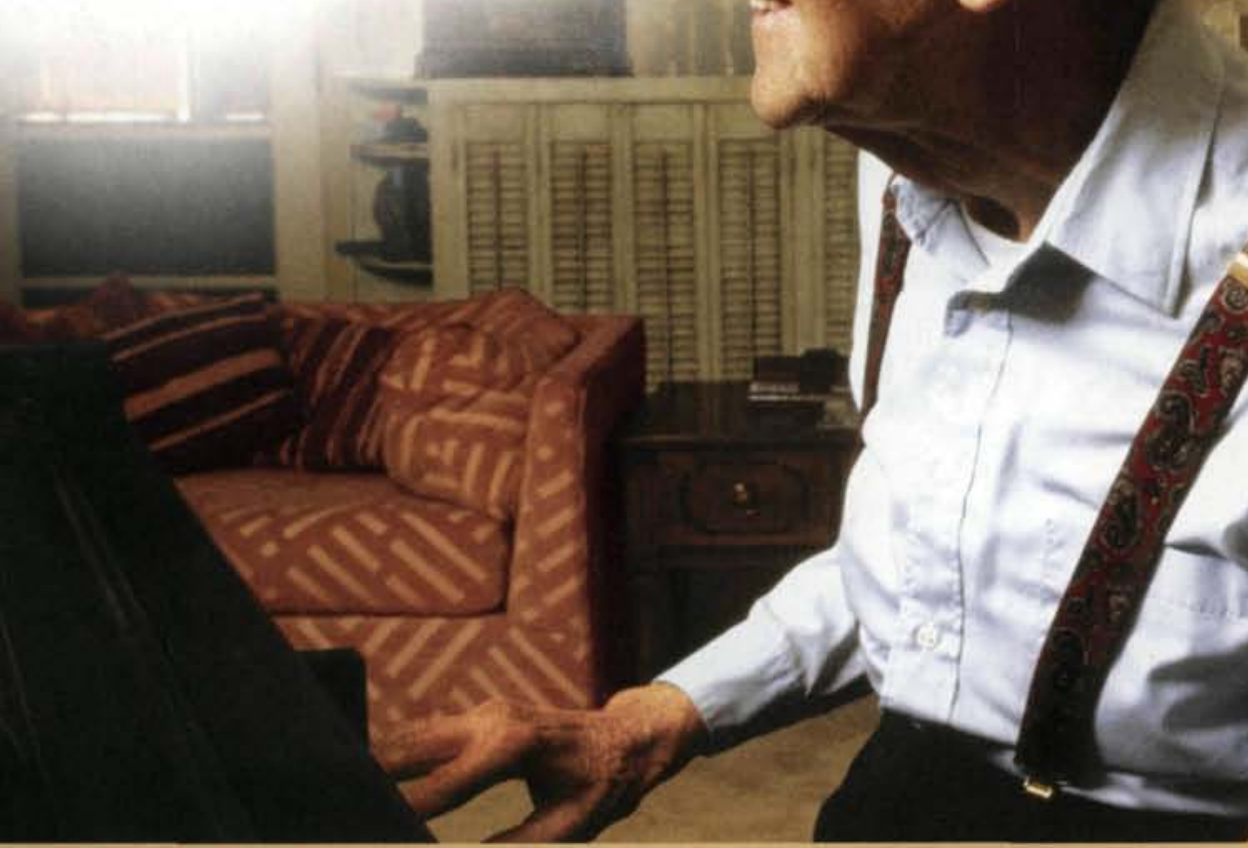

Since its launch, Aricept" sales and prescriptions have been leading the way in the fight against dementia of the Alzheimer's type.'

- Over six years of excellent efficacy supported by more than 1 billion patient days worldwide ${ }^{2.5 t 5}$

- Excellent safety and tolerability profiles ${ }^{6}$

- Convenient once-a-day dosing ${ }^{6}$

- A wealth of clinical studies

Aricept' is indicated for the symptomatic treatment of patients with mild-to-moderate dementia of the Alzheimer's type, and does not change the underlying course of the disease.

With appropriate dose escalation, $5 \mathrm{mg} / \mathrm{d}, 10 \mathrm{mg} / \mathrm{d}$ and placebo were shown to have comparable adverse events, the most common being diarmea, nausea, insomnia, fatigue, vomiting, muscle cramps and anorexia. These are usually mild and transient, resolving with continued treatment without need for dose modification.

IT IS

NO WONDER

THAT ARICEPT*

IS THE \#1

PRESCRIBED

AD TREATMENT

IN CANADA.'

t In a 52 - week, multicentre, double-bind, placebo-controlled study, 286 mid- to-moderate AD patients were randomzed to receive Arioept" 5 mg/d tor 28 days (in=142), followed by $10 \mathrm{mrg} / \mathrm{d}$, as per cinicazis judgement, ox placebo (n=144).

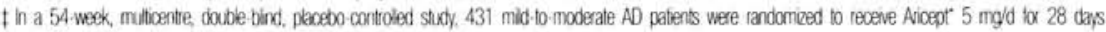
anc 10 mylo thereatles, a placobo.

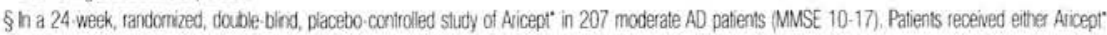
$5 \mathrm{mg} / \mathrm{d}$ tox the first 28 days and $10 \mathrm{mg} / \mathrm{d}$ thereatter, as per crinician's judgement (n=102), or placebo $(n=105)$.

Product Morograph avaliable on request.

- IM Eisai Co Lits., Tokyo, degen, Plizer Canada fic, licensee Q 2003, Pliver Caradia lnc., Kirkarnd, Ouebec. H9J 2M5

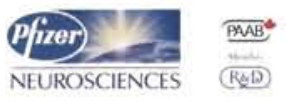

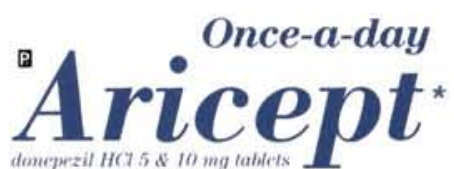

Experience defines us.

For brief prescribing information see page A-27 